

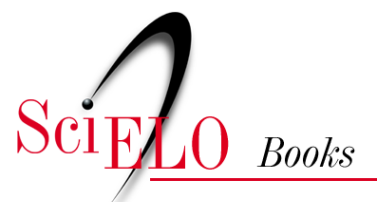

\title{
Ativismo institucional: criatividade e luta na burocracia brasileira
}

\author{
Rebecca Neaera Abers (org.)
}

\section{SciELO Books / SciELO Livros / SciELO Libros}

ABERS, R. N., ed. Ativismo institucional: criatividade e luta na burocracia brasileira [online]. Brasília: Editora UnB, 2021, 356 p. ISBN: 978-65-5846159-3. https://doi.org/10.7476/9786558461593.

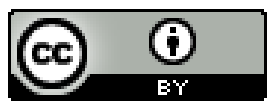

All the contents of this work, except where otherwise noted, is licensed under a $\underline{\text { Creative }}$ Commons Attribution 4.0 International license.

Todo o conteúdo deste trabalho, exceto quando houver ressalva, é publicado sob a licença Creative Commons Atribição 4.0.

Todo el contenido de esta obra, excepto donde se indique lo contrario, está bajo licencia de la licencia Creative Commons Reconocimento 4.0. 
Ativismo
institucional criatividade e luta na burocracia brasileira 


\section{$\$ Universidade de Brasília}

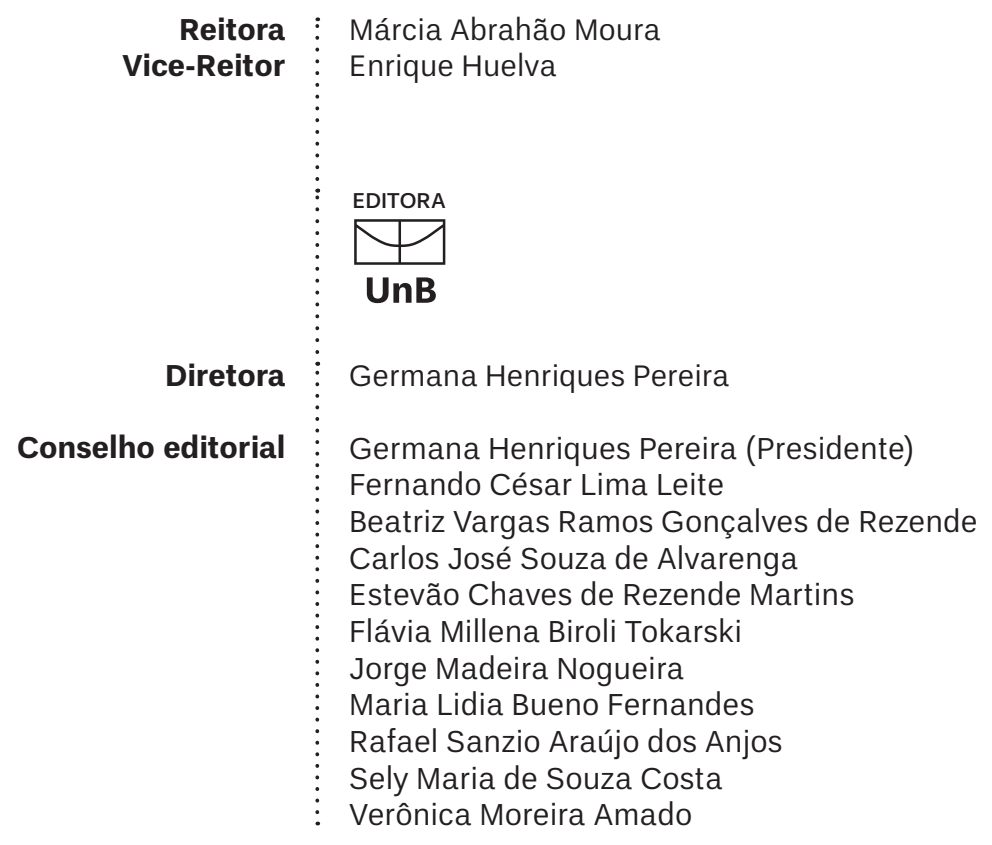





\section{Coordenadora de produção editorial}

Revisão

Diagramação e capa

\section{Equipe editorial}

Marília Carolina de Moraes Florindo

Berttoni Licarião

Wladimir de Andrade Oliveira

(C) 2020 Editora Universidade de Brasília

Direitos exclusivos para esta edição:

Editora Universidade de Brasília

SCS, quadra 2, bloco $C, n^{\circ} 78$, edifício OK,

$2^{\circ}$ andar, CEP 70302-907, Brasília, DF

Telefone: (61) 3035-4200

Site: www.editora.unb.br

E-mail:contatoeditora@unb.br

Todos os direitos reservados. Nenhuma parte desta publicação poderá ser armazenada ou reproduzida por qualquer meio sem a autorização por escrito da Editora.

Ficha catalográfica elaborada pela Biblioteca Central da Universidade de Brasília

A872 Ativismo institucional : criatividade e luta na burocracia brasileira

/ Rebecca Neaera Abers (org.). - Brasília : Editora

Universidade de Brasília, 2021.

356 p. ; $23 \mathrm{~cm}$.

ISBN 978-65-5846-004-6

1. Burocracia. 2. Movimentos sociais. 3. Ativismo. 4. Política pública. I. Abers, Rebecca Neaera (org.).

CDU 32(81)

Impresso no Brasil 


\section{Agradecimentos}

Como qualquer atividade criativa, a construção deste livro dependeu da ação de muitos parceiros e parceiras para além do grupo de pesquisadores que participaram diretamente da confecção dos capítulos. Em relação a apoios financeiros, agradecemos ao Conselho Nacional de Desenvolvimento Científico e Tecnológico (CNPq), pelo financiamento de diversas atividades relacionadas a esta pesquisa, especialmente a realização de entrevistas e suas transcrições. ${ }^{1}$

Durante o curso de pós-graduação, vários autores receberam bolsas que possibilitaram sua dedicação ao desenvolvimento do trabalho aqui apresentado. Agradecemos à Coordenação de Aperfeiçoamento de Pessoal de Nível Superior (Capes) pelas diversas bolsas de mestrado, doutorado, doutorado sanduíche e pós-doutorado concedidas; ao Conselho Nacional de Desenvolvimento Científico e Tecnológico pelas bolsas de mestrado e de doutorado sanduíche; ao Instituto de Ciência Política e ao Decanato de Pós-Graduação da Universidade de Brasília pelo auxílio financeiro para o desenvolvimento de pesquisa de campo; e ao Instituto da Democracia e da Democratização da Comunicação (INCT) por uma bolsa de pós-doutorado.

Somos gratos aos membros, estudantes e professoras do grupo de Pesquisa Repensando as Relações Sociedade e Estado - Resocie, que criaram um ambiente fértil para debates sobre a natureza do ativismo e dos movimentos sociais. Agradecemos especialmente o apoio intelectual e emocional das Professoras Marisa von Bülow e Debora Rezende. Somos igualmente gratos ao Instituto de Ciência Política e à Universidade de Brasília, por fornecerem ambiente e incentivos acadêmicos necessários para o desenvolvimento das nossas atividades, desde espaço físico até recursos materiais e estímulos intelectuais.

1 Financiamento obtido no processo n ${ }^{\circ} 448506 / 2014-9$. 
Este projeto ainda ganhou força e corpo em conjunto com os estudantes de duas turmas da disciplina Criatividade Política, ministrada no curso de pós-graduação de Ciência Política da Universidade de Brasília, cujas ideias centrais que orientam esta obra foram debatidas com generosidade e entusiasmo.

Ao longo do processo de desenvolvimento da pesquisa e dos trabalhos apresentados neste livro, pesquisadores de outras instituições foram interlocutores importantes: Adrian Gurza Lavalle, Al Montero, Camila Penna, Eduardo Marques, Euzeneia Carlos, Gabriela Lotta, Jessica Rich, Lindsay Mayka, Luciana Tatagiba, Marcelo Kunrath Silva, Margaret Keck, Monika Dowbor, Ricardo Fabrino Mendonça, Roberto Pires, Rogerio Arantes, dentre outros.

A investigação em campo, que conferiu concretude aos conceitos teóricos propostos, só pôde ser realizada com o acesso proporcionado pelas instituições estatais pesquisadas e com a disponibilidade e atenção demonstradas pelos servidores e servidoras, protagonistas de ideias e ações criativas na burocracia, que merecem nosso reconhecimento e gratidão.

Expressamos agradecimento especial à Editora da Universidade de Brasília que acreditou no potencial desta obra e nos concede a oportunidade de torná-la pública para conhecimento e aproveitamento de seu conteúdo não apenas pela comunidade acadêmica, mas pela sociedade como um todo. 


\section{Lista de abreviaturas e siglas}

\begin{tabular}{|c|c|}
\hline Abema & $\begin{array}{l}\text { Associação Brasileira de Entidades de } \\
\text { Meio Ambiente }\end{array}$ \\
\hline Abia & Associação Brasileira Interdisciplinar de AIDS \\
\hline ACP & Ação Civil Pública \\
\hline ANA & Agência Nacional de Águas \\
\hline Aneel & Agência Nacional de Energia Elétrica \\
\hline Asmare & $\begin{array}{l}\text { Associação de Catadores de Materiais } \\
\text { Recicláveis de Belo Horizonte }\end{array}$ \\
\hline Assemae & $\begin{array}{l}\text { Associação Nacional de Serviços Municipais de } \\
\text { Saneamento }\end{array}$ \\
\hline BM & Belo Monte \\
\hline BNDES & $\begin{array}{l}\text { Banco Nacional de Desenvolvimento } \\
\text { Econômico e Social }\end{array}$ \\
\hline Cams & $\begin{array}{l}\text { Comissão de Articulação com os } \\
\text { Movimentos Sociais }\end{array}$ \\
\hline CBO & Classificação Brasileira de Ocupações \\
\hline CCFDS & $\begin{array}{l}\text { Conselho Curador do Fundo de } \\
\text { Desenvolvimento Social }\end{array}$ \\
\hline $\mathrm{CDC}$ & Center for Disease Control and Prevention \\
\hline CEF & Caixa Econômica Federal \\
\hline CGU & Controladoria Geral da União \\
\hline Chesf & Companhia Hidrelétrica do São Francisco \\
\hline Ciisc & $\begin{array}{l}\text { Comitê Interministerial de Inclusão Social dos } \\
\text { Catadores de Lixo }\end{array}$ \\
\hline Cnaids & $\begin{array}{l}\text { Comissão Nacional de DST, AIDS e } \\
\text { Hepatites Virais }\end{array}$ \\
\hline
\end{tabular}




\begin{tabular}{|c|c|}
\hline Cohid & $\begin{array}{l}\text { Coordenação de Energia Hidrelétrica e } \\
\text { Transposição }\end{array}$ \\
\hline Conab & Companhia Nacional de Abastecimento \\
\hline Conama & Conselho Nacional de Meio Ambiente \\
\hline Concidades & Conselho Nacional das Cidades \\
\hline Consea & $\begin{array}{l}\text { Conselho Nacional de Segurança } \\
\text { Alimentar e Nutricional }\end{array}$ \\
\hline Contag & $\begin{array}{l}\text { Confederação Nacional dos Trabalhadores } \\
\text { da Agricultura }\end{array}$ \\
\hline Coomgrif & $\begin{array}{l}\text { Cooperativa Mista dos Garimpeiros da Ressaca, } \\
\text { Itata, Galo, Ouro Verde e Ilha da Fazenda }\end{array}$ \\
\hline Coopamare & $\begin{array}{l}\text { Cooperativa de Catadores de Materiais } \\
\text { Recicláveis de São Paulo }\end{array}$ \\
\hline $\mathrm{CPT}$ & Comissão Pastoral da Terra \\
\hline CTH & Câmara Técnica de Habitação \\
\hline DAS & Direção e Assessoramento Superior \\
\hline Deter & Detecção do Desmatamento em Tempo Real \\
\hline Devit & $\begin{array}{l}\text { Departamento de Vigilância das Doenças } \\
\text { Transmissíveis }\end{array}$ \\
\hline Diahv & $\begin{array}{l}\text { Departamento de Infecções Sexualmente } \\
\text { Transmissíveis, AIDS e Hepatites Virais }\end{array}$ \\
\hline Dilic & Diretoria de Licenciamento Ambiental \\
\hline Dnaee & Departamento Nacional de Água e Energia Elétrica \\
\hline DPU & Defensoria Pública da União \\
\hline EIA & Estudo de Impacto Ambiental \\
\hline FAF & Fortalecimento da agricultura familiar \\
\hline Farrgs & $\begin{array}{l}\text { Federação das Associações de Recicladores do } \\
\text { Rio Grande do Sul }\end{array}$ \\
\hline Fase & $\begin{array}{l}\text { Federação de Órgãos para Assistência } \\
\text { Social Educacional }\end{array}$ \\
\hline FBB & Fundação Banco do Brasil \\
\hline
\end{tabular}




\begin{tabular}{|c|c|}
\hline FDA & Food and Drug Administration \\
\hline FDS & Fundo de Desenvolvimento Social \\
\hline FGV & Fundação Getúlio Vargas \\
\hline FNEPR & $\begin{array}{l}\text { Fórum Nacional dos Estudos sobre a } \\
\text { População de Rua }\end{array}$ \\
\hline FNLC & Fórum Nacional Lixo e Cidadania \\
\hline FNPETI & $\begin{array}{l}\text { Fórum Nacional de Prevenção e Erradicação do } \\
\text { Trabalho Infantil }\end{array}$ \\
\hline FNPR & $\begin{array}{l}\text { Fórum Nacional de Estudos sobre a } \\
\text { População de Rua }\end{array}$ \\
\hline FNRU & Fórum Nacional pela Reforma Urbana \\
\hline FNSA & Frente Nacional pelo Saneamento Ambiental \\
\hline FSAN & Fortalecimento da segurança alimentar \\
\hline Funai & Fundação Nacional do Índio \\
\hline Funasa & Fundação Nacional de Saúde \\
\hline Gapa & Grupo de Apoio à Vida \\
\hline Geri-FCE-UFBA & $\begin{array}{l}\text { Grupo de Estudos de Relações Intersetoriais da } \\
\text { Faculdade de Ciências Econômicas da } \\
\text { Universidade Federal da Bahia }\end{array}$ \\
\hline Girsu & Gestão Integrada de Resíduos Sólidos urbanos \\
\hline GT & Grupo de Trabalho \\
\hline GTI & Grupo de Trabalho Interministerial \\
\hline HIS & Habitação de Interesse Social \\
\hline Incra & $\begin{array}{l}\text { Instituto Nacional de Colonização e } \\
\text { Reforma Agrária }\end{array}$ \\
\hline Ibama & $\begin{array}{l}\text { Instituto Brasileiro do Meio Ambiente e dos } \\
\text { Recursos Naturais Renováveis }\end{array}$ \\
\hline Ibase & $\begin{array}{l}\text { Instituto Brasileiro de Análises Sociais } \\
\text { e Econômicas }\end{array}$ \\
\hline IBGE & Instituto Brasileiro de Geografia e Estatística \\
\hline
\end{tabular}




\begin{tabular}{|c|c|}
\hline ICMBio & Instituto Chico Mendes de Biodiversidade \\
\hline Imaflora & $\begin{array}{l}\text { Instituto de Manejo e Certificação Florestal } \\
\text { e Agrícola }\end{array}$ \\
\hline Inpe & Instituto Nacional de Pesquisas Espaciais \\
\hline INSS & Instituto Nacional de Seguro Social \\
\hline Ipea & Instituto de Pesquisa Econômica Aplicada \\
\hline Iphan & $\begin{array}{l}\text { Instituto do Patrimônio Histórico e } \\
\text { Artístico Nacional }\end{array}$ \\
\hline ISA & Instituto Socioambiental \\
\hline LI & Licença de Instalação \\
\hline $\mathrm{LO}$ & Licença de Operação \\
\hline LP & Licença Prévia \\
\hline LU & Limpeza urbana \\
\hline MAB & Movimento dos Atingidos por Barragens \\
\hline MCIDADES & Ministério das Cidades \\
\hline MCMV & Minha Casa Minha Vida \\
\hline MCMV-E & Minha Casa Minha Vida - Entidades \\
\hline MDA & Ministério de Desenvolvimento Agrário \\
\hline MDS & $\begin{array}{l}\text { Ministério do Desenvolvimento Social e } \\
\text { Combate à Fome }\end{array}$ \\
\hline Mesa & Ministério Extraordinário da Segurança Alimentar \\
\hline MMA & Ministério do Meio Ambiente \\
\hline MMTR & Movimento de Mulheres Trabalhadoras Rurais \\
\hline MNCR & $\begin{array}{l}\text { Movimento Nacional dos Catadores de } \\
\text { Materiais Recicláveis }\end{array}$ \\
\hline MP & Ministério Público \\
\hline MPA & Movimento dos Pequenos Agricultores \\
\hline MPF & Ministério Público Federal \\
\hline
\end{tabular}




\begin{tabular}{ll} 
MST & Movimento dos Sem Terra \\
MTE & Ministério do Trabalho e Emprego \\
NE & Norte Energia \\
OGU & Orçamento Geral da União \\
OMC & Organização Mundial do Comércio \\
OMS & Organizações de movimentos sociais \\
ONG & Organização Não Governamental \\
PAA & Programa de Aquisição de Alimentos \\
PAC & Programa de Aceleração do Crescimento \\
Padeq & Plano de Ação para a Prevenção e Controle do \\
PBF & $\begin{array}{l}\text { Desmatamento, Queimadas e Exploração } \\
\text { Madeireira Ilegal }\end{array}$ \\
PCS & Programa Bolsa Família \\
PDRS-X & Programa Crédito Solidário \\
Prodocs & $\begin{array}{l}\text { Plano de Desenvolvimento Regional Sustentável } \\
\text { do Xingu }\end{array}$ \\
Prar & Plano de Emergência do Presidente para a \\
PGPM & Pssistência à AIDS \\
PNRS & Política de Garantia de Preços Mínimos \\
PNobio & Política Nacional de Resíduos Sólidos \\
\hline Políticas Nacional de Saneamento Básico
\end{tabular}




$\begin{array}{ll}\text { Pronaf } & \begin{array}{l}\text { Programa de Fortalecimento da } \\ \text { Agricultura Familiar }\end{array} \\ \text { PRSU } & \text { Programa Resíduos Sólidos Urbanos } \\ \text { PSDB } & \text { Partido da Social Democracia Brasileira } \\ \text { PSM } & \text { Programa Social de Moradia } \\ \text { PT } & \text { Partido dos Trabalhadores } \\ \text { Rima } & \text { Relatório de Impacto Ambiental } \\ \text { RPL } & \text { Relatório do Processo Ambiental } \\ \text { RPL } & \text { Relatório do Processo de Licenciamento } \\ \text { Saip } & \text { Secretaria de Articulação Institucional e Parcerias } \\ \text { SBF } & \text { Secretaria de Biodiversidade e Florestas } \\ \text { SCA } & \text { Secretaria de Coordenação da Amazônia } \\ \text { SDS } & \text { Secretaria de Desenvolvimento Sustentável } \\ \text { Sedu-PR } & \text { Secretaria de Desenvolvimento Urbano da } \\ \text { Sema-RS } & \text { Presidência da República } \\ \text { SRHAU } & \text { Secretaria Estadual do Meio Ambiente do } \\ \text { Senaes } & \text { Rio Grande do Sul } \\ \text { Senarc } & \text { Secretaria Nacional de Economia Solidária } \\ \text { Sesan } & \text { Secretaria de Qualidade Ambiental nos } \\ \text { SFB } & \text { Secretaria Nacional de Renda de Cidadania } \\ \text { SLU } & \text { Secretaria Nacional de Segurança } \\ \text { Alimentar e Nutricional }\end{array}$


SUS

Sistema Único de Saúde

TCU

Tribunal de Contas da União

TVR

Trecho de vazão reduzida

UBS

Unidades Básicas de Saúde

Unicef

Fundo das Nações Unidas para a Infância 


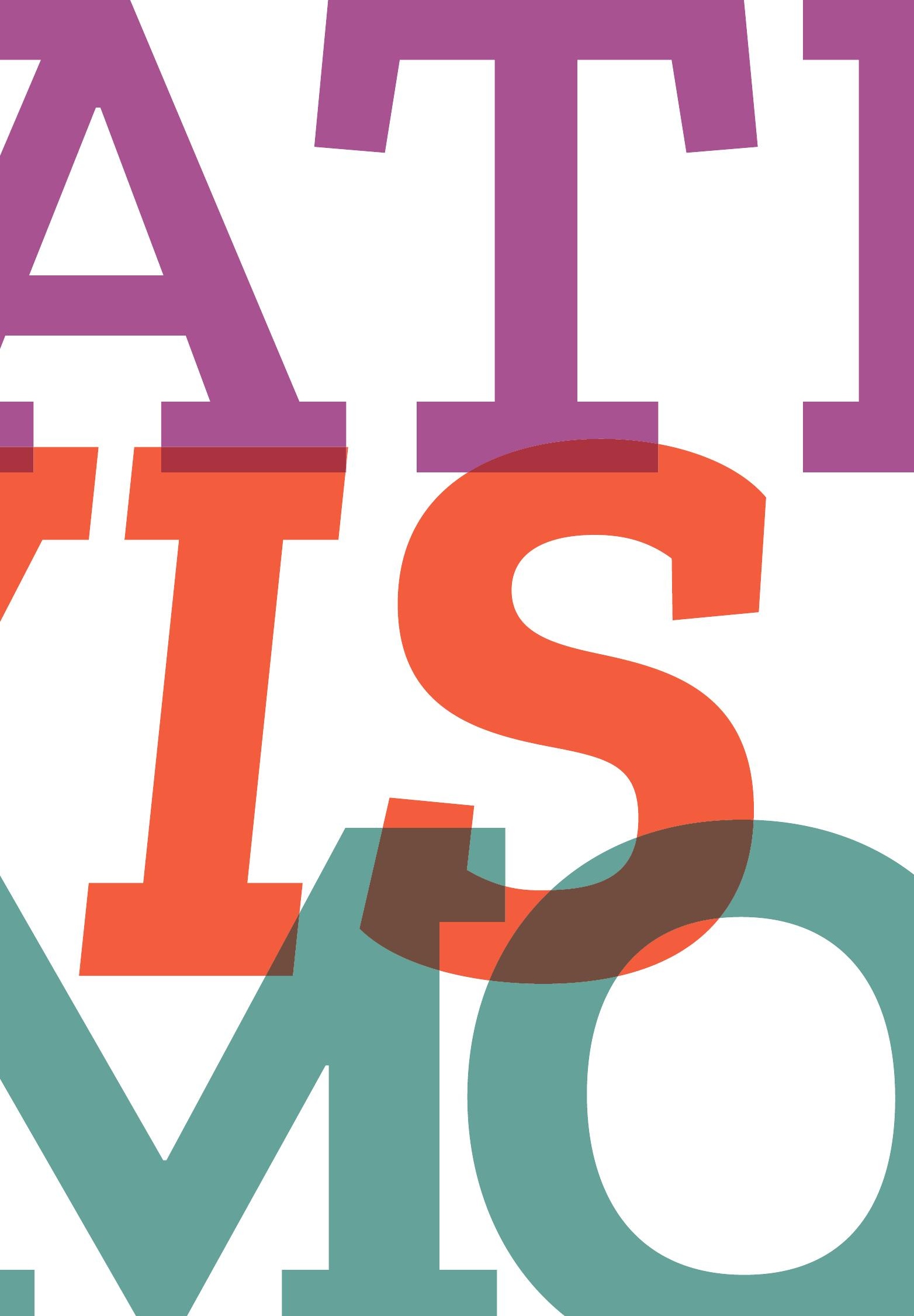




\section{Sumário}

Ação criativa, ativismo e lutas no interior do Estado 17 Rebecca Neaera Abers

Parte 1

\section{ATIVISMO SITUADO NA HISTÓRIA}

Capítulo 1

Ativismo institucional e enquadramentos interpretativos: discutindo as causas do ativismo de burocratas na criação do programa de aquisição de alimentos 55

Lucas Alves Amaral

Capítulo 2

Efeito ricochete: trajetórias técnico-políticas e a criação de novos modelos de políticas públicas 89

Igor Brandão

Parte 2

\section{ATIVISMO SITUADO EM CONTEXTOS}

\section{Capítulo 3}

Movimentos sociais, ocupação de cargos públicos e políticas públicas: uma relação de sucesso. $\bigcirc$ caso da produção do Plano de Prevenção e Combate ao Desmatamento na Amazônia - PPCDAM 123

Marília Silva de Oliveira 
Capítulo 4

Para além do gabinete: o ativismo de procuradores no caso da Usina de Belo Monte 155

Luiz Henrique Vilaça

Capítulo 5

Ativismo institucional em empreendimentos de

infraestrutura: autonomia e discricionariedade no caso

da Hidrelétrica Belo Monte 189

Ana Karine Pereira

Capítulo 6

Ativismo e construção de significado: a política de AIDS do governo federal 221

Mariana Gomes Cartaxo

Parte 3

\section{ATIVISMO EM AÇÃO}

Capítulo 7

Programa Minha Casa Minha Vida - Entidades:

ativismo institucional no acesso à terra urbanizada 255

Rafael Viana

Capítulo 8

Ativismo de servidores na educação para a democracia:

os parlamentos mirins no Brasil 287

Ana Marusia Pinheiro Lima

Capítulo 9

Entre a inclusão e a exclusão: criatividade em contextos de controvérsias 323

Paula Pompeu Fiuza Lima 


\section{Ação criativa, ativismo e lutas no interior do Estado}

Rebecca Neaera Abers

Ativismo institucional parece uma contradição em termos. Se instituições são, por definição, ordens que se autorreproduzem, o termo ativismo evoca a ideia de transformação. Na contramão do senso comum, este livro procura sinais de agitação no interior das instituições governamentais. Encontramos grupos de servidores públicos que contestam hierarquias e o status quo, propondo maneiras alternativas de organizar as políticas governamentais ou resistindo a tentativas de desmonte de conquistas anteriores. A proposta deste livro não é afirmar que todo servidor é ou poderia ser ativista, mas, simplesmente, explorar a possiblidade de que a burocracia pode ser uma arena de luta em favor da inclusão política e da justiça social e ambiental. Quem se torna ativista? O que fazem? Quais são os recursos que usam e como? Quais estratégias empregam? Como estas estratégias mudam em diferentes contextos? São as perguntas que mobilizam esta obra.

Nesta introdução, apresento as bases teóricas para uma definição de ativismo institucional e busco, por meio da apresentação dos oito estudos empíricos incluídos neste livro, mostrar como este conceito pode ser aplicado. Estudar este fenômeno traz contribuições importantes para a pesquisa sobre 
os movimentos sociais. Nas últimas décadas, vários estudiosos desse campo colocaram a distinção rígida entre política institucional e não institucional (e entre movimentos sociais e o Estado) em xeque (BANASZAK, 2010; GOLDSTONE, 2003; GUIGNI; PASSY, 1998). Meyer (2005) e Guigni e Passy (1998) notam que, quando governos aceitam demandas de movimentos sociais, estes frequentemente ganham acesso ao processo de desenho, implementação e monitoramento da política proposta. Este livro, dando um passo além, foca em atores que defendem causas a partir de postos governamentais, sejam como servidores permanentes, sejam em cargos de confiança. Explorar este tipo de ativismo desestabiliza conceitos tradicionais na literatura de movimentos sociais sobre quem luta, quais repertórios de contestação política empregam e em quais arenas atuam.

A noção de ativismo institucional também desafia concepções prevalentes no estudo do Estado e das instituições políticas. Há mais de trinta anos, um grupo de sociólogos e cientistas políticos questionou a tendência, tanto no marxismo quanto no pluralismo, de esvaziar conceitualmente o interior do Estado, deixando-o como uma caixa preta a serviço de classes dominantes ou grupos de interesse. Ao propor "trazer o Estado de volta”, Skocpol, Rueschemeyer e Evans (1985) recuperaram a ideia weberiana de que burocratas seriam atores com seus próprios interesses, valores, inteligência e recursos. Mas a atenção cada vez maior na ciência política às instituições e, especialmente, aos mecanismos de reprodução delas, dificultou o olhar para a transformação. A mudança aconteceria, para muitos institucionalistas, apenas em “conjunturas críticas”, quando as forças de dependência da trajetória que reproduzem as instituições estivessem mais frágeis (COLLIER; COLLIER, 1991; MAHONEY, 2001). Como atores repentinamente liberados de amarras institucionais fariam suas escolhas nestas conjunturas foi pouco teorizado. Neste livro entendo burocracias como "instituições habitadas” (HALLETT; VENTRESCA, 2006). Ou seja, é impossível entender as instituições como operando por mecanismos anônimos de reprodução: é preciso examinar os valores, papéis e estratégias dos servidores públicos que participam diretamente da reprodução ou transformação delas.

O conceito de ativismo institucional evoca a ideia de contestação, mesmo se o ator nem sempre emprega o que a literatura de movimentos sociais entende como táticas contestatórias (protestos, ocupações, 
abaixo-assinados, etc). Lutar no interior das instituições pode envolver o uso de rotinas institucionais (a produção de manuais, protocolos, decretos e relatórios; a realização de reuniões e seminários técnicos, etc) para fins contestatórios. De qualquer maneira, ativismo envolve enfrentar resistências. Estudá-lo significa examinar processos que na maioria das vezes não serão bem-sucedidos, devido justamente às desigualdades de poder entre os vários atores que habitam as instituições. Movo-me não pela crença de que burocracias são normalmente transformadas por ativismo, e sim pelo exame de processos que mostram que, mesmo em uma ecologia hostil como a burocracia estatal, as sementes de luta conseguem sobreviver.

No Brasil, questionar a dicotomia entre sociedade civil e Estado como arenas distintas de ação política não é nada novo. A proliferação a partir dos anos 1990 de instituições participativas - como orçamentos participativos, conselhos gestores, conferências, etc - estimulou uma ampla literatura sobre o envolvimento de movimentos sociais em processos decisórios governamentais. A partir do governo Lula, outro fenômeno começou a capturar a atenção de estudiosos de movimentos sociais: a ocupação por ativistas de cargos governamentais (DAGNINO et al., 2006; DOWBOR, 2012; HOCHSTETLER; KECK, 2007; ABERS; SERAFIM; TATAGIBA, 2014; ABERS; OLIVEIRA, 2015; OLIVEIRA, 2016; RICH, 2013; SILVA, 2015). Inspiradas por essa literatura, as pesquisas apresentadas neste livro buscam contribuir para a construção de um marco teórico que ajude a compreender como esse tipo de ator afeta o desenho e a implementação de políticas públicas.

O objetivo desta introdução é apresentar os principais conceitos que fundamentaram o projeto de pesquisa em que os estudos contidos neste volume foram elaborados, além de sistematizar alguns dos principais achados. Nas próximas duas seções, apresento as bases teóricas do conceito de ativismo institucional. Primeiro, argumento que a definição de ativismo deve partir de um conceito de ação em geral que a entende como ao mesmo tempo criativa e situada em contextos. Realizo um levantamento seletivo de como diferentes autores explicam o papel de atores no mundo institucionalizado. Em seguida, defendo um conceito pragmatista de ação criativa que enxerga o contexto não apenas como constrangimento, mas também como constitutivo da ação. Segundo, busco na literatura sobre movimentos sociais algumas dicas sobre como definir o ativismo. Argumento que os debates 
teóricos sobre a ação coletiva e sobre confronto político são especialmente úteis para este fim. Com esses pontos de partida, na terceira seção apresento uma definição de ativismo institucional como um subtipo de ação criativa que envolve ação coletiva no interior de instituições na defesa de causas contenciosas. A quarta seção apresenta o projeto de pesquisa que orientou este livro e descreve os oito capítulos empíricos contidos nele. Essa última seção é dividida em três subseções, cada uma correspondendo a uma parte do livro. Busco mostrar como os capítulos que compõem cada parte possibilitam avanços na compreensão de três temas centrais no estudo do ativismo institucional: o processo histórico no qual são construídas as causas pelas quais os ativistas institucionais lutam; a maneira que ativistas se relacionam com os contextos institucionais, políticos e sociais em que se inserem; e a sistematização de práticas e estratégias empregadas no ativismo institucional.

\section{Ação, estrutura e criatividade}

O conceito "dupla face” de ativismo institucional se sustenta em uma concepção mais ampla de ação segundo a qual estrutura e ação são mutuamente constituídas. As instituições só existem porque são afirmadas na prática por meio da ação. Ao mesmo tempo, a ação não é apenas constrangida por instituições, mas depende delas. Na sociologia contemporânea, a mútua constituição de ação e estrutura é a pedra fundamental das obras de autores como Bourdieu (1977) e Giddens (1984). Os conceitos de habitus, de Bourdieu, e de "estruturação", de Giddens, introduzem ação na explicação das estruturas ao afirmar que a reprodução delas só acontece porque atores sociais praticam regras, normas e papéis a cada dia. Sewell (1992) repara, no entanto, que ambos os autores deram mais atenção a processos de reprodução estrutural do que à mudança. Não apresentaram explicações convincentes do porquê atores poderiam em alguns momentos resistir ou transformar as regras vigentes.

Para Sewell, duas ideias mal desenvolvidas em Giddens (1984) podem contribuir para preencher essa lacuna. Primeiro, Giddens critica a ideia de que indivíduos são cultural dopes (idiotas culturais): eles têm capacidade 
crítica; são knowledgable, ou capazes de ter conhecimento e compreensão. Segundo, Giddens teoriza que estruturas não são compostas apenas por regras que ditam o que se deve fazer em determinada situação. Estruturas também incluem recursos que atores usam quando agem.

Mesmo assim, a obra de Giddens, bem como a de Bourdieu, carecem de uma explicação teórica convincente de como atores poderiam interpretar regras e usar recursos de maneira diferente. Já que cada indivíduo é inserido cognitivamente em um mundo em que os únicos papéis e normas que conhecem são aqueles que predominam, é difícil imaginar como fariam para interromper o ciclo por meio do qual as instituições se reproduzem. ${ }^{1}$

Uma solução insatisfatória é atribuir poder transformador apenas àqueles indivíduos que detêm recursos excepcionais. O termo “empreendedor”, usado tanto na sociologia quanto na ciência política, geralmente designa indivíduos dotados de capacidades ou recursos extraordinários, o que os possibilita escapar do ciclo reprodutivo inexorável que prende as pessoas comuns. DiMaggio (1977, p. 14), em texto clássico do institucionalismo sociológico, afirma que "novas instituições surgem quando atores organizados com recursos suficientes (empreendedores institucionais) enxergam nelas uma oportunidade de realizar interesses aos quais eles atribuem alto valor”. Na ciência política, encontro ideias semelhantes. Para Dahl (1961, p. 6), por exemplo, líderes políticos são pessoas excepcionais, “que sabem usar seus recursos até o máximo”. O termo - empreendedor - também tem uso corrente na literatura de políticas públicas. Kingdon (1995, p. 122) define o empreendedor por "sua vontade de investir seus recursos - tempo, energia, reputação e às vezes dinheiro - na esperança de um retorno futuro”. Em todas essas definições, a mudança é restrita a atores com recursos extraordinários.

Pensadores mais recentes, especialmente da sociologia, criticam essa visão "heroica" da ação, que essencialmente atribui poderes transformadores apenas a atores que são tão especiais que as regras sociais não se aplicam a eles, da mesma maneira que as leis da gravidade não se aplicam

1 Deve ser notado que em palestras de Bourdieu posteriores à crítica de Sewell, a ação ganha mais vida em sua teoria do Estado. 
ao Super-Homem. Para Lawrence, Suddaby e Leca (2009, p. 1, tradução nossa), por exemplo, é necessária

uma visão mais ampla da ação em relação a instituições, uma que evite descrever atores ora como "idiotas culturais" aprisionados por arranjos institucionais, ora como empreendedores institucionais hipermusculares. ${ }^{2}$ (LAWRENCE; SUDDABY; LECA, 2009, p. 1, tradução nossa).

Encontro no pragmatismo um marco conceitual especialmente robusto para conceber a relação entre ação e estrutura de maneira que não sobrevalorize a reprodução estrutural como fazem Giddens e Bourdieu, nem remeta ao passe de mágica da ação heroica para explicar iniciativas humanas que eventualmente desafiam a reprodução. O pragmatismo encontra suas origens no pensamento de filósofos estadunidenses do século 18 e na primeira parte do século 20, como Charles Sanders Pierce, Henry James e John Dewey. Temas centrais para o pensamento pragmatista são a crítica da separação cartesiana de corpo e mente, e a ênfase no conhecimento derivado da experiência no mundo e na interação com outras pessoas. Pragmatistas também tendem a rejeitar categorias e antinomias fixas, o que facilita a compreensão de fenômenos humanos aparentemente paradoxais como o ativismo institucional. O pensamento de Dewey $(1922,1933,1934)$ é especialmente útil para esta agenda de pesquisa, pela maneira como o autor caracteriza a ação por um tensionamento constante entre rotina e mudança. O motivador central dessa tensão é a natureza "problemática” do mundo, que impossibilita a manutenção automática da rotina.

A obra mais contemporânea de Hans Joas (1996) ajuda a explicar por que o pragmatismo oferece uma solução para o problema da relação entre ação e estrutura. Joas argumenta que a sociologia da ação é dividida em duas tradições antagônicas, ambas equivocadas: a tese de que a ação é “racional”, envolvendo indivíduos inteligentes que fazem cálculos de

2 “[...] a broader vision of agency in relationship to institutions, one that avoids depicting actors either as 'cultural dopes' trapped by institutional arrangement, or as hypermuscular institutional entrepreneurs” (LAWRENCE; SUDDABY; LECA, 2009, p. 1). 
custo e benefício; e a de que o indivíduo é essencialmente um seguidor de normas ou regras definidas pela sociedade. Se a primeira tese supervaloriza a racionalidade, a segunda supervaloriza a força das estruturas sobre o indivíduo. Para Joas, no entanto, ação envolve ao mesmo tempo a inteligência do ator e sua inserção em estruturas materiais e cognitivas.

Joas bebe da ideia pragmatista de que o contexto em que o ator atua tende a ser problemático, não oferecendo regras claras que possam ser simplesmente seguidas. "Nossas ações habituais encontram resistência do mundo e reverberam de volta sobre nós” (1996, p. 128-129). Para lidar com essas reverberações, o ator experimenta. O mundo problemático exige a ação criativa, que por sua vez afeta o mundo. Por meio de processos constantes de experimentação, atores não somente aprendem sobre os problemas, mas modificam o mundo em que atuam, mesmo de forma extremamente incremental.

Chave no pensamento de Joas é a ideia de que tais atos criativos não representam a capacidade do ator de se livrar das normas culturais, papéis sociais, regras políticas ou distribuições materiais de recursos. Pelo contrário, este contexto produz a matéria-prima que o ator usa para experimentar. A experimentação prática ocorre somente porque o ator tem predisposições e valores adquiridos em seu contexto social e sua trajetória de vida. Assim, seguindo Dewey (1922), não há uma clara distinção entre o momento da rotina ou do hábito e o uso da inteligência ou vontade. A capacidade reflexiva somente pode ser usada a partir dos recursos e capacidades preexistentes.

Situações não desencadeiam nossas ações, mas também não apenas fornecem o terreno no qual realizamos nossas intenções. Nossa percepção da situação é predefinida em nossas capacidades para ação e nossa atual disposição para ação. Nossa resposta reflexiva ao desafio que nos é apresentado pela situação decide qual ação é tomada. (JOAS, 1996, p. 161, tradução nossa). ${ }^{3}$

3 "Situations do not trigger our actions, but nor do they merely provide the terrain on which we carry out our intentions. Our perception of the situation is predefined in our capacities 
Dois movimentos possibilitam a compreensão da ação como criativa nestes termos: por um lado, entender reflexividade e crítica como características humanas; por outro, abandonar a ideia de que as estruturas e instituições sociais são perfeitamente sólidas. Inspirado por pragmatistas e pelo pensamento de Joas, esse segundo movimento é chave na crítica feita por Berk e Galvan sobre o institucionalismo na ciência política:

O que aconteceria se, inspirados por pragmatistas clássicos como John Dewey e sucessores como Hans Joas, nós tratássemos a vida institucional como a experiência vivida de regras e as instituições como recursos sempre sujeitos a decomposição, rearranjados e reutilizados como resultado da própria ação? Isso significaria deixar de lado descrições de instituições como constrangimentos estruturais da ação, caminhos temporais de regularidade, mecanismos exógenos de socialização, ou padrões inculcados de cognição. [...] Ordem, bem como mudança, se tornaria resultado compreensível de ação dentro e por meio de instituições. (BERK; GALVAN, 2009, p. 543, tradução nossa). ${ }^{4}$

Se esses autores enfatizam a natureza construída das instituições, outros argumentam que sobreposições entre múltiplas instituições também impelem o ator à criatividade. Ansell (2013) sugere que, frequentemente, em vez de servirem como regras claras que nos orientam, instituições coexistem em ecologias ultracomplexas, caracterizadas por sobreposições e contradições. "Mudança institucional surge como produto das circunstâncias heterodoxas

for action and our current disposition for action. Our reflective response to the challenge presented to us by the situation decides which action is taken" (JOAS, 1996, p. 161).

4 "What if, borrowing from classical pragmatists like John Dewey and successors like Hans Joas (1993, 1996), we treated institutional life as the lived experience of rules, and institutions as always-decomposable resources, rearranged and redeployed as a result of action itself? This would mean setting aside depictions of institutions as structural constraints on action, temporal pathways of regularity, exogenous mechanisms of socialization, or ingrained patterns of cognition. [...] Order, as well as change, would become understandable outgrowths of action in and through institutions.” (BERK; GALVAN, 2009, p. 543). 
geradas por esta ecologia, que requer que atores engajam em 'criatividade situada”" (ANSELL, 2013, p. 57, tradução nossa). ${ }^{5}$

Com um foco maior em como atores enfrentam problemas morais, a "sociológica da crítica" de Boltanski e Thévenot (1999) parte da ideia de que se vive simultaneamente em múltiplos “mundos” de justificação moral. Um mesmo ato pode ser justificável no mundo doméstico, por exemplo, porém inaceitável no mundo do mercado. O conflito entre essas "ordens de grandeza” produz o que os autores chamam de controvérsias. A partir dessa proposta, os autores descrevem um processo experimental de crítica social em que atores produzem "provas" (dados, documentos, leis) que lidam com controvérsias e, eventualmente, encontram saídas.

As ideias discutidas anteriormente são apenas algumas entre uma diversidade de abordagens sociológicas e na ciência política que reafirmam o insight central de Joas de que a ação ocorre não como negação de estruturas, mas a partir delas, como enfrentamento crítico de um mundo problemático. Essa concepção ajuda a explicar a ação inserida em estruturas por duas razões. Por um lado, entendem-se as estruturas ou instituições não como ordens que automaticamente se reproduzem, mas como contextos que criam rotinas e crenças e distribuem recursos de maneira frequentemente problemática. Isso significa que não é incomum que o ator seja obrigado a usar a capacidade criativa para decidir o que fazer. Por outro lado, esses atos criativos não são superações heroicas em que o ator consegue se livrar das estruturas em que se situa. Pelo contrário, as mesmas rotinas (hábitos), crenças e recursos são a matéria-prima que o ator vai ter que usar para lidar com os problemas.

Tal concepção de ação, em que atores frequentemente são obrigados a agir criativamente com os instrumentos cognitivos e materiais disponibilizados pelo contexto problemático em que se situam, descreve ação em geral, e não somente o ativismo. As próximas seções especificam o ativismo como um subtipo de ação criativa. Para tal, trazem alguns conceitos da literatura de movimentos sociais.

5 "Institutional change arises as the product of heterodox circumstances generated by this ecology, which requires actors to engage in 'situated creativity'” (ANSELL, 2013, p. 57). 


\section{Confronto e ação coletiva}

Embora raramente dialogue explicitamente com o pragmatismo, ${ }^{6}$ boa parte da literatura sobre movimentos sociais também reconhece, pelo menos implicitamente, a qualidade dupla da ação que defendo anteriormente, ou seja, a ação é ao mesmo tempo criativa e inserida em estruturas. A própria ideia de movimento social sugere a coexistência de instituições que colocam alguns grupos sociais em condições de desvantagem estrutural e a possibilidade de que esses mesmos grupos possam promover transformações. Para explicar como atores com pouca força podem almejar à transformação, a literatura de movimentos sociais - especialmente aquela associada à chamada "teoria do processo político" - traz dois conceitos importantes: o confronto político e a ação coletiva.

A ideia de confronto surge na literatura de movimentos sociais como ponto de partida da própria discussão sobre o que distinguiria um movimento de outro tipo de agregação social. Vários autores clássicos da literatura colocaram conflitos no cerne da definição de movimento social. Touraine (1978) definiu movimentos como atores sociais envolvidos em lutas para a direção da história, o que ele chamava de historicidade. Em cada momento, o desenvolvimento histórico dependeria de conflitos específicos. Melucci (1989) definiu movimentos como uma ação coletiva que gira em torno de um conflito com "um adversário que reivindica os mesmos bens ou valores" (1989, p. 29). Esses dois autores reservavam o termo "movimento social" apenas para conflitos que eles consideravam centrais na sociedade ou, nos termos de Melucci, "sistêmicos”. Tilly (1978) não fazia essa distinção, estando mais interessado na disseminação generalizada do que chamava de "política contenciosa" (contentious politics), definida como:

6 Para exceções, ver Cefaï (2009) e Gross (2010). 
interação episódica, pública, coletiva entre reivindicadores e seus objetos quando a) pelo menos um governo é um reivindicador, objeto de reivindicação ou parte de uma reivindicação; e b) as reivindicações, se cumpridas, afetariam os interesses de pelo menos um dos reivindicadores. (MCADAM; TARROW; TILLY, 2001, p. 5, tradução nossa). ${ }^{7}$

Para Diani (1992), o foco de autores como Tilly e colegas em confronto político esconde a natureza conflituosa de muitas lutas culturais que não se manifestam em relações com governos. Para ele,

atores de movimento social se engajam em conflitos políticos e/ou culturais, com a intenção de promover a mudança social em nível sistêmico ou não sistêmico ou se opor a ela. (DIANI, 1992, p. 11, tradução nossa). ${ }^{8}$

Em resumo, todas essas discussões sugerem que movimentos envolvem disputas em torno de ordens sociais instituídas, ou seja, instituições. Alguns movimentos buscam transformar instituições existentes; outros o que Touraine (1999) chamou de movimentos históricos - lutam contra mudanças institucionais consideradas indesejáveis.

Defino as ideias que mobilizam essas lutas como causas contenciosas. Mais especificamente, proponho definir uma causa contenciosa como um objetivo que envolve a defesa ou a crítica de mudanças nas instituições que organizam as relações de poder na sociedade. Ao envolver, assim, relações institucionalizadas de poder, uma causa contenciosa precisa ser defendida contra forças poderosas de estabilidade ou mudança. Quando se trata de políticas públicas, causas contenciosas tendem a se operacionalizar

7 “[...] Episodic, public, collective interaction among makers of claims and their objects when (a) at least one government is a clamant, an object of claims, or a party to the claim; and (b) the claims would, if realized, affect the interests of at least one of the claimants.” (MCADAM; TARROW; TILLY, 2001, p. 5).

8 "Social movement actors are engaged in political and/or cultural conflicts, meant to promote or oppose social change either at the systemic or non-systemic level.” (DIANI, 1992, p. 11). 
na forma de modelos alternativos de vida ou de política pública que, se implementados, implicariam em mudanças profundas de práticas sociais estabelecidas e de relações de poder (TATAGIBA; ABERS; SILVA, 2018). Destarte, já que instituições são regras sociais que tendem a se reproduzir, pode-se dizer que causas contenciosas têm a ver, por definição, com mudança institucional, seja no sentido favorável, seja contrário.

Como distinguir uma causa contenciosa de outro tipo de ideia que mobiliza atores? Na essência da ideia de causa está a crítica ou defesa das instituições básicas que os atores entendem como causadoras das condições sociais ou políticas que detestam ou prezam. Se o fenômeno social identificado realmente tem esse poder causal a ele atribuído não é importante para esta análise: ser uma causa é uma interpretação dos atores que a defendem. Assim, uma ideia se torna uma causa contenciosa quando seus defensores acreditam que algo fundamental da sociedade ou das relações de poder está ameaçado ou em necessidade de defesa. Mesmo assim, é provável que não exista uma linha clara entre uma causa contenciosa e outros objetivos que atores podem defender, até porque sempre haverá disputas sobre as causas dos problemas sociais existentes ou sobre a relevância de diferentes assuntos.

A segunda dimensão de ação salientada pela literatura de movimentos sociais é a mobilização coletiva: movimentos envolvem a reunião de vários atores em torno de objetivos comuns. O debate sobre ação coletiva parte do reconhecimento de que Olson (1965) tinha certa razão: não é possível explicar ação coletiva coordenada entre atores em prol de um bem maior a partir dos pressupostos racionalistas e individualistas que predominam na ciência política e na economia. A capacidade de superar os dilemas de ação coletiva identificadas pela abordagem de escolha racional foi explicada de diversas maneiras, todas envolvendo situar atores em contextos mais amplos, como organizações (MCCARTHY; ZALD, 1977), redes sociais (SNOW et al., 1980; MCADAM, 1986) e dinâmicas políticas (TARROW, 1994). Outros enfatizam os contextos simbólicos: pessoas se mobilizam a partir de suas crenças sobre quais são os problemas mais importantes que a sociedade enfrenta e como resolvê-los (SNOW et al., 1986), ou ainda sobre identidades coletivas (MELUCCI, 1996), pela mobilização de emoções (JASPER, 2011), por meio de de rotinas conhecidas (TILLY, 2008), ou pela combinação entre fatores (MCADAM; MCARTHY; ZALD, 1996; 
MCADAM; TARROW; TILLY, 2001). Em resumo, essa literatura rica se dedicou intensamente a explicar por que e como atores agem coletivamente.

Vários dos autores descrevem processos de mobilização em termos muito próximos à ideia que discuto anteriormente, de que ação surge a partir de contextos, e não apesar deles. Para Melucci (1989, p. 25), por exemplo, a ação coletiva envolve um processo cognitivo por meio do qual indivíduos interpretam os contextos:

ação coletiva é [...] o produto de orientações propositais desenvolvidas em um campo de oportunidades e constrangimentos. Indivíduos agindo coletivamente constroem sua ação ao definir em termos cognitivos estas possiblidades e limites. (tradução nossa). ${ }^{9}$

Tilly (2008) também reuniu atenção para as estruturas sociais com o reconhecimento de que movimentos são criativos (GROSS, 2010). Ele usa o conceito de "repertório" para descrever o rol de rotinas e práticas conhecidas e socialmente aceitas para a ação coletiva (marchas, abaixo-assinados, barricadas, etc.) e "performance”, para descrever um ato especifico de empregar uma rotina:

a metáfora teatral chama a atenção para o caráter agrupado, apreendido, porém improvisado das interações entre pessoas quando eles fazem e recebem reivindicações. Reivindicar normalmente parece jazz e commedia dell'arte mais que a leitura ritual de escrituras. (TILLY, 2008, p. 14, tradução nossa). ${ }^{10}$

Tanto Melucci quanto Tilly exemplificam a maneira com que estudiosos de movimentos sociais exploram a mútua constituição de agência

9 "Collective action is [...] the product of purposeful orientations developed within a field of opportunities and constraints. Individuals acting collectively construct their action by defining in cognitive terms these possibilities and limits [...]” (MELUCCI, 1989, p. 25).

10 "The theatrical metaphor calls attention to the clustered, learned, yet improvisational character of people's interactions as they make and receive each other's claims. Claim making usually resembles jazz and commedia dell'arte rather than ritual reading of scripture." (TILLY, 2008, p. 14). 
e estrutura: movimentos reproduzem práticas históricas (repertórios), porque são essas que as pessoas conhecem e legitimam. Ao mesmo tempo, improvisam. Aliás, o sucesso de muitos movimentos amiúde depende da sua capacidade de surpreender (TARROW, 1994).

\section{Definindo ativismo institucional}

Com o apoio conceitual do pragmatismo e das teorias sobre movimentos sociais, construo o conceito de ativismo institucional como um tipo específico de ação criativa. Essa iniciativa acompanha uma pequena literatura fora do Brasil que vem usando o termo "ativismo institucional” (PETTINICCIO, 2012; BANASZAK, 2010), ou termos próximos como "ativismo interno" (OLSSON; HYSING, 2012). Alguns desses autores tratam de funcionários eleitos, como deputados negros ou mulheres que defendem os direitos dos grupos aos quais pertencem (SANTORO; MCGUIRE, 1997). Outros enfatizam que servidores concursados ou nomeados podem agir como ativistas. Alguns definem ativistas como trabalhadores governamentais que fazem parte de redes da sociedade civil e "agem estrategicamente de dentro da administração pública para mudar política e ação governamentais em linha com um compromisso de valor pessoal” (OLSSON; HYSING, 2012, p. 258, tradução nossa). ${ }^{11}$ Outros, como Pettinicchio (2012) e Banaszak (2010) sugerem que servidores públicos podem ser ativistas mesmo sem fazerem parte de redes de movimentos sociais externos ao Estado. Apesar de trazer contribuições importantes, nenhuma dessas definições realmente explora o que seria característica do ativismo institucional em relação a outras formas de ação no interior de instituições.

A maior parte do trabalho a ser feito aqui se relaciona à definição da primeira parte do conceito "ativismo", termo muito utilizado na literatura de movimentos sociais, porém raramente definido (JOYCE, 2014). O primeiro passo nesse sentido foi tomado na discussão sobre pragmatismo:

11 "[...] acts strategically from inside public administration to change government policy and action in line with a personal value commitment.” (OLSSON; HYSING, 2012, p. 258). 
ativismo pode ser entendido como um subtipo de ação criativa, ou seja, envolve agir reflexivamente, usando a capacidade crítica e a inteligência humana, a partir de contextos que produzem problemas, constrangimentos e recursos que possibilitam a ação. Essas características são, como Joas (1996) mostra, intrínsecas a ação intencional em geral.

A partir da discussão sobre movimentos sociais, proponho que ativismo, como subtipo de ação criativa, tem duas características especiais. Primeiro, ativismo é ação orientada para a defesa de causas contenciosas, como definidas na seção anterior. Sejam causas favoráveis ou contrárias a mudanças na organização institucional das relações de poder, essa parte do conceito incorpora o caráter conflituoso em geral associado aos movimentos sociais. Isso não quer dizer que todas as práticas ativistas sejam conflituosas: um ator pode perseguir uma causa por meio de práticas negociadoras ou conciliatórias. Mas a orientação da ação em torno de uma causa significa que mesmo práticas convencionais ou cooperativas têm como objetivo avançar a perspectiva ou agenda de um lado do confronto.

Segundo, entendo que ativismo envolve a ação coletiva. Ou seja, embora muitas vezes pessoas que têm muita iniciativa própria e comprometimento sejam consideradas ativistas, a discussão anterior chama a atenção para o ativismo como uma prática em grupo. A natureza coletiva do ativismo remete ao problema do conceito "heroico" da ação criticado anteriormente. Se ativismo evoca a imagem de pessoas com pouco poder individual lutando contra forças poderosas, a ação coletiva seria uma maneira de reunir recursos e capacidades para esse empreendimento. Em geral, ativismo é realizado por atores que, uma vez que agem coletivamente em prol de causas, participam de movimentos sociais, entendidos como um tipo de rede (DIANI, 1992). Mas a ação coletiva do ativismo também pode ocorrer por fora de movimentos sociais por meio de outros tipos de redes, como de servidores públicos ou grupos de profissionais.

Esse percurso conceitual, resumido no quadro 1, leva à seguinte definição de ativismo: ação coletiva em prol de causas contenciosas, entendidas como projetos que colocam as instituições em questão, seja para transformá-las, seja para defendê-las contra ameaças percebidas. Entendo, assim, que ativismo é por definição um tipo de ação que sempre envolve instituições. 
Quadro 1: Bases do conceito de ativismo

\begin{tabular}{|c|c|c|}
\hline \multicolumn{2}{|c|}{ Conceitos } & $\begin{array}{c}\text { Fontes de inspiração } \\
\text { teórica }\end{array}$ \\
\hline \multicolumn{2}{|c|}{ Ação e estruturas se constituem mutuamente } & \multirow{3}{*}{$\begin{array}{l}\text { Giddens, Bourdieu, } \\
\text { Sewell }\end{array}$} \\
\hline Contextos estruturais & Atores são ao mesmo & \\
\hline são “problemáticos” & "inseridos em contextos & \\
\hline \multicolumn{2}{|c|}{$\begin{array}{l}\text { Ação criativa é inteligente e situada; contexto } \\
\text { (normas e crenças sociais, distribuições de recursos } \\
\text { materiais, redes de relacionamentos) ao mesmo } \\
\text { tempo constrange e propicia instrumentos }\end{array}$} & \multirow[t]{2}{*}{ Pragmatismo } \\
\hline \multicolumn{2}{|c|}{ Ativismo é um subtipo de ação criativa } & \\
\hline \begin{tabular}{l|} 
Ativismo é orientado por \\
causas contenciosas (ideias \\
que defendem ou contestam \\
instituições que organizam \\
relações de poder)
\end{tabular} & $\begin{array}{l}\text { Ativismo envolve } \\
\text { ação coletiva }\end{array}$ & $\begin{array}{l}\text { Literatura de } \\
\text { movimentos sociais }\end{array}$ \\
\hline
\end{tabular}

Da definição de ativismo para o conceito de ativismo institucional é um passo curto. A palavra institucional aqui se refere mais ao local da luta do que ao objeto: ativismo institucional seria então a ação coletiva em prol de causas contenciosas quando realizada por atores em instituições. Pode envolver ação coletiva com outros atores governamentais, com atores não governamentais, ou ambos. ${ }^{12}$

Estudar o ativismo institucional promete trazer várias contribuições para o estudo de ativismo mais geral. Toda ação - e, portanto, todo ativismo - é situada em contextos que constrangem e facilitam a ação simultaneamente. $\mathrm{O}$ ativismo no interior de instituições é de certa maneira mais

${ }^{12}$ Também entendo que ativismo pode ocorrer no interior de instituições não governamentais, como em empresas ou instituições religiosas. Embora esse tipo de ativismo não seja o objeto deste livro, deixamos a definição em aberto por hora na esperança de estimular estudos sobre esses tipos de arenas. 
constrangido do que o ativismo fora delas, já que a lógica hierárquica das organizações governamentais impõe muitas regras e limites sobre o que o ator pode fazer. Agir contra a agenda dos governantes a partir de postos governamentais pode ser especialmente difícil e exigir o que Olsson (2016) chama de subversão institucional. Ao mesmo tempo, o ativista institucional tem acesso a certos tipos de recursos que o extragovernamental não tem: publicar um protocolo a ser implementado por múltiplas instituições governamentais pode, por exemplo, ter um efeito enorme em favor de uma causa. $\mathrm{O}$ ativismo institucional pode, então, ser entendido como um caso especial de ativismo em que tanto os limites quanto os recursos para ação são especialmente grandes.

Estudar o ativismo institucional também é interessante da perspectiva do estudo das instituições estatais, por duas razões. Primeiro, ao explorar um tipo de ação que é (por definição) contestatória, esse livro torna visível um tipo de conflito que a literatura sobre processos governamentais tende a ignorar. Se estudos brasileiros sobre "presidencialismo de coalizão" apresentam o Estado brasileiro como uma arena de disputa entre múltiplos grupos políticos, o estudo do ativismo adiciona o papel de atores que podem ser marginalizados da coalizão governamental. Segundo, ao focar em ação coletiva, a presente obra contribui para debates sobre a natureza “relacional” do Estado (MARQUES, 2006), mostrando que servidores não somente operam em redes sociais, mas também em alguns casos agem juntos na construção de modelos alternativos.

\section{O projeto de pesquisa e a estrutura do livro}

Este livro resulta de um projeto de pesquisa por meio do qual propus analisar o ativismo institucional a partir da realização de estudos de caso em que atores burocráticos buscaram influenciar o desenho e a implementação de políticas públicas no Brasil. Procuro entender o ativismo institucional tanto como variável dependente (o que leva os atores a se engajarem no ativismo?), quanto como variável independente (quais são os efeitos do ativismo sobre as políticas?), mas principalmente em seu aspecto processual. Ou seja, além de entender as causas e os efeitos do ativismo, desejo 
compreender melhor como o ativismo institucional opera: quais as estratégias mais usadas? Quais recursos são mobilizados? Como essas respostas variam entre atores em diferentes tipos de posições (cargos comissionados versus servidores permanentes) ou com diferentes tipos de trajetórias e redes profissionais (pessoas com experiência de luta em movimentos sociais fora do Estado, pessoas sem este tipo de experiência)? Qual a diferença entre o ativismo institucional em torno de políticas públicas criadas com muita ou pouca participação de movimentos sociais externos ao Estado?

A escolha metodológica do estudo de caso aprofundado foi proposital, pois essa abordagem é a melhor para compreender a ação situada. Se a criatividade envolve o improviso no uso de recursos materiais, simbólicos e relacionais encontrados nas instituições em que o ator se situa, é preciso compreender a relação entre atores e instituições para entender o que fazem. Conforme classicamente definido por Yin (1984), o estudo de caso - em que um único ou vários casos são selecionados para estudo aprofundado - envolve a compreensão de um fenômeno de forma holística, em toda sua complexidade e inserido em um contexto. A realização de estudos de caso sobre uma política pública oferece a oportunidade de compreender os problemas contextualizados que os atores enfrentam. Somente assim é possível enxergar a criatividade das soluções inventadas ou os esforços contidos em atos aparentemente nada inovadores.

Contextualizar o ativismo por meio do estudo de caso aprofundado, no entanto, tem custos. É preciso não apenas entrevistar os atores identificados como potenciais "ativistas", mas traçar suas redes de interação, conhecer seus parceiros e aliados, às vezes em outras instituições. Também exige conhecer os fatores que limitam o ativismo e as forças que se opõem a ele. O pesquisador precisa assim conhecer a fundo as organizações em que os atores trabalham por meio de entrevistas não somente com os identificados como ativistas, mas com outros tipos de informantes. Ainda precisa coletar e analisar documentos oficiais e comentários públicos e levantar literaturas secundárias sobre a instituição, a política pública e o subsistema de política em tela. Em geral, um bom estudo de caso envolve dezenas de entrevistas aprofundadas com atores diversos. Esta estratégia de pesquisa naturalmente limita o número de casos que um único pesquisador poderá realizar. 
Para atingir um número de casos que permitisse certa comparabilidade, optei por orientar um conjunto de teses e dissertações; cada uma das quais contribuiria para a exploração conceitual e empírica do ativismo institucional ao mesmo tempo que constituiria uma obra em si, resultado de anos de pesquisa de cada autor. Assim, em vez de seguir um roteiro único, em que cada estudo testasse a mesma hipótese a partir da mesma base teórica, cada estudo teve uma iniciativa exploratória própria, que buscaria desenvolver insights teóricos sobre o problema do ativismo institucional a partir de diferentes experiências e em diálogo com diferentes literaturas discutidas anteriormente. Embora todos os orientandos fossem influenciados pela discussão teórica que eu desenvolvia, aquela discussão também foi evoluindo em interação com as pesquisas deles e contou com suas importantes contribuições.

Cada capítulo deste livro é baseado no marco conceitual discutido anteriormente e dialoga com outras abordagens para aprofundar teoricamente diferentes aspectos do fenômeno em tela. O livro foi dividido em três partes, cada uma delas buscando explorar uma dimensão do problema teórico do ativismo institucional.

\section{O ativismo institucional situado na história}

A primeira parte do livro examina dois casos em que redes sobrepostas de atores localizados em diferentes tipos de instituições construíram novos modelos de política pública nas décadas anteriores ao governo Lula. As redes e competências criadas durante aquele passado foram fundamentais para dar suporte ao ativismo institucional em prol dessas políticas depois de 2003.

No capítulo 1, Lucas Amaral examina o ativismo institucional na criação do Programa de Aquisição de Alimentos (PAA), política instituída no primeiro governo Lula para ser o marco central do combate à fome por meio de compras públicas da agricultura familiar. O texto reflete sobre como o conceito de enquadramentos interpretativos pode ser útil para nos ajudar a entender a complexidade e historicidade das causas contenciosas que mobilizam o ativismo institucional de burocratas, principalmente quando os ativistas não são oriundos de movimentos sociais, mas tem um perfil, em 
geral, mais acadêmico e técnico. O PAA, segundo Amaral, é uma solução para os problemas colocados à agricultura familiar e à segurança alimentar e nutricional no Brasil nas décadas anteriores. Pode ser entendido como o resultado de um trabalho de acoplamento de dois enquadramentos distintos, o do fortalecimento da segurança alimentar e nutricional e o do fortalecimento da agricultura familiar. Amaral mostra como esses enquadramentos foram sendo articulados ao longo das décadas anteriores à eleição de Lula por uma rede sobreposta de defensores localizada em diversas instituições estatais e não estatais. Dessa forma, o texto do autor contribui para este livro ao problematizar a relação entre ativismo e causas contenciosas, mostrando a utilidade do conceito de enquadramentos interpretativos no entendimento das causas que orientam o ativismo institucional.

O capítulo 2, de Igor Brandão, analisa o efeito das trajetórias profissionais de um grupo específico de atores no processo de construção institucional da Política Nacional de Resíduos Sólidos (PNRS). Para explicar como a inclusão de catadores foi adotada como componente central de um modelo alternativo de política de gestão de resíduos no Brasil, Brandão acompanha o trabalho de atores técnicos e políticos em diferentes arenas ao longo de três décadas: organizações não governamentais, governos locais, fóruns temáticos, organismos internacionais, o governo federal, entre outros. Em diálogo com literaturas sobre circulação de elites, redes de governança, e mudança institucional, o autor argumenta que as trajetórias constituídas a partir da experiência em arenas do Estado e da sociedade civil produziram um "efeito ricochete", gerando competências e reconhecimentos tais que habilitaram esse grupo de atores a mediar a mudança do regime brasileiro de políticas de resíduos.

Ambos os estudos situam o ativismo institucional do período petista na história de lutas institucionais e não institucionais de grupos de atores que vinham construindo não somente ideias, mas também redes e capacidades no período anterior. Esses recursos contribuiriam decisivamente para criar apoio político para tais agendas. Os estudos atentam para o fato de que causas são construções históricas e de que a capacidade de ativistas influenciarem as políticas públicas é frequentemente criada a longo prazo. Os grupos de burocratas ativistas que defenderam esses modelos (bem como outros discutidos em outras partes do volume) foram formados ao 
longo de décadas de experimentação, em governos locais, em entidades não governamentais, por meio de projetos de pesquisa e extensão universitários, e em outras arenas.

Os capítulos mostram que o processo de experimentação opera em múltiplos níveis. Por um lado, é por meio de várias experiências anteriores que os atores constroem os conceitos básicos de um modelo alternativo. Por outro lado, esses processos experimentais também promovem a criação de capacidades técnicas e de redes de apoio que podem ser mobilizadas futuramente. Assim, em consonância com a perspectiva pragmatista, esses estudos demonstram que a experimentação não somente produz aprendizado no sentido de aperfeiçoar conhecimentos, mas também transforma o terreno de ação em que ocorre a ação criativa.

\section{O ativismo institucional situado em contextos}

Se a primeira parte do livro situa o ativismo institucional em histórias de luta, a segunda parte mostra o valor de enxergar o ativismo como situado em contextos que fornecem matéria-prima para a ação.

No capítulo 3, Marilia Oliveira analisa a atuação de um conjunto de burocratas oriundos do movimento ambientalista que assumiram cargos no Ministério de Meio Ambiente sob o comando de Marina Silva. O capítulo busca explicar como esses atores conseguiram promover uma política pública de substancial impacto, o Plano de Prevenção e Combate ao Desmatamento na Amazônia (PPCDAm). Seguindo a proposta de Tatagiba, Abers e Silva (2018), Oliveira analisa esse processo como fruto da interação entre vários níveis de análise: o regime (a coalizão política que incorporou Silva ao governo Lula), o subsistema de política pública (política ambiental) e o movimento social (ambientalista). O argumento central é que os ambientalistas conseguiram reunir capacidade técnica com capacidade político-partidária. A primeira se acumulava a partir do trabalho anterior em Organizações Não Governamentais ambientalistas altamente profissionalizadas, de maneira semelhante ao que foi visto nos casos do PAA e da gestão de resíduos sólidos. A segunda vinha da relação entre segmentos do movimento ambientalista com o Partido dos Trabalhadores 
e com o governo Lula. A participação de membros do movimento em posições chaves da coalizão política é fator importante para explicar a implementação do programa.

No capítulo 4, Luiz Vilaça estuda um grupo de procuradores do Ministério Público Federal envolvidos na construção da barragem hidrelétrica de Belo Monte. Ele procura explicar por que um grupo deles se tornou defensor ferrenho das comunidades atingidas pela obra. Vilaça testa e descarta as duas teses dominantes na literatura para explicar os compromissos de burocratas, a autosseleção de pessoas com determinados valores no momento da entrada no serviço público e a socialização por uma cultura organizacional após a contratação. O autor argumenta que o comprometimento de alguns procuradores com a causa das comunidades afetadas é resultado de um terceiro fator, o contato com as populações afetadas após chegar à cidade. Assim, ao mostrar que o compromisso com causas derivou da interação com atores da sociedade no cotidiano do trabalho dos procuradores, o capítulo contribui para este debate sobre como a inserção do ator em um contexto afeta suas identidades e preferências.

O capítulo 5, de Ana Karine Pereira, examina o mesmo caso, a partir de outra ótica. Para entender como atores estatais mobilizam recursos existentes nas instituições em que trabalham, a autora explora como analistas ambientais responsáveis por emitir pareceres sobre a concessão de licenciamento ambiental da hidrelétrica de Belo Monte tentaram diminuir os impactos sobre comunidades locais. Para tal, buscaram recursos em duas dimensões do contexto institucional, a autonomia (entendida como a capacidade de agir) e a discricionariedade (entendida como liberdade de agir). A autora mostra que a discricionariedade em torno do processo de licenciamento ambiental, resultado da ambiguidade das regras sobre os procedimentos técnicos a serem realizados, permitiu que os técnicos interpretassem seu papel no processo de aprovação da licença de maneira criativa. A falta de autonomia, no entanto, limitou o alcance dessas ações. Desse modo, a análise da discricionariedade e da autonomia serve como uma janela útil para entender a dupla face das estruturas institucionais, que operam ao mesmo tempo como constrangimentos e como recursos que possibilitam a ação. 
No capítulo 6, Mariana Cartaxo aponta para a percepção dos ativistas institucionais sobre sua capacidade de agir ao examinar como servidores da política de AIDS interpretam mudanças no contexto organizacional de seu trabalho. Desde os anos 1990, a política nacional de AIDS tem sido caracterizada pela construção conjunta de uma rica rede de atores estatais e não estatais (RICH, 2013). O estudo de Cartaxo examina o impacto, em 2009, da criação do Departamento de IST, AIDS e Hepatites Virais (Diahv) do Ministério da Saúde. A partir da obra de Hallett e Ventresca (2006), a autora explora como atores que "habitam" instituições as interpretam simbolicamente. Ela mostra como a criação do departamento abalou a crença entre servidores de que tinham autonomia para criar as "redes de sociabilidade" que viabilizavam a política. Assim, esse estudo ajuda a entender a maneira como servidores ativistas comprometidos com um modelo alternativo de gestão agem a partir de suas crenças sobre mudanças institucionais.

Examinar lutas que ocorrem no interior de instituições coloca em xeque pressupostos de boa parte da literatura sobre movimentos sociais que compreende as instituições políticas como "estruturas de oportunidades" externas aos movimentos. Em texto recente, com Silva e Tatagiba (TATAGIBA; ABERS; SILVA, 2018), proponho redefinir oportunidades políticas como estruturas relacionais em que atores são inseridos. A intenção é mostrar que contextos não devem ser entendidos como condições externas que limitam a ação, e sim como um conjunto de relações em que o ator participa.

Ao mostrar que ativistas fazem parte das relações sociais que compõem o contexto, os textos dessa parte do livro dão sustento a essa proposta. No caso do combate ao desmatamento (capítulo 3), os atores do movimento ambientalista faziam parte, mesmo de maneira marginalizada, do regime político vigente, especialmente em função da liderança de Marina Silva, ator ao mesmo tempo partidário e ambientalista. Nos casos de Belo Monte (capítulos 4 e 5), o ativismo dos técnicos de licenciamento ambiental e dos procuradores é dificultado não tanto por instituições anônimas quanto pela força de outros atores (criativos) no governo que defendiam o avanço acelerado da obra.

Os textos também mostram a maneira complexa por meio da qual os contextos criam condições para a ação. No texto de Pereira (capítulo 5), regras ambíguas criam possiblidades para ação discricionária e instituições 
que distribuem poder para outros atores diminuem a influência dos ativistas, mas nenhum desses fatores instrucionais determina o que os atores vão fazer. Foi por meio de interações com outros atores estatais e não estatais que os técnicos de licenciamento ambiental construíram suas estratégias criativas. O texto de Cartaxo sobre a política de AIDS (capítulo 6) também acentua a natureza indeterminada do arranjo institucional em que atores se situam ao chamar a atenção para como grupos de atores constroem simbolicamente interpretações sobre as estruturas institucionais e sobre o efeito delas em sua capacidade de agir.

\section{O ativismo institucional em ação}

Na última parte do livro, os capítulos oferecem importantes análises não somente para entender os antecedentes e condicionantes do ativismo, mas também para explorar como o ativismo acontece, ou seja, para identificar práticas e estratégias típicas do ativista que age no interior de instituições.

No capítulo 7, Rafael Viana explora uma política desenhada em proximidade com movimentos populares, o Programa Minha Casa Minha Vida - Entidades (MCMV-E). Desde o início do governo Lula, o movimento de moradia discutiu com o Ministério das Cidades a implementação de um modelo alternativo de produção de habitação popular baseado na autogestão por entidades de moradores. Essas experiências foram atropeladas pela criação do Programa Minha Casa Minha Vida em 2009, que se organizava em torno de um modelo completamente diferente, de construção por empreiteiras. Em resposta a críticas dos movimentos, o MCMV-E foi criado baseado no modelo autogestionário. Viana examina o papel de burocratas do programa - a maioria dos quais não era originária dos movimentos - na defesa deste modelo. Em diálogo com o pragmatismo francês, Viana contribui para o estudo de “como” opera o ativismo, mostrando o papel de ativistas institucionais como mediadores e tradutores entre Estado e movimentos sociais em torno da controvérsia entre diferentes modelos de produção de habitação popular.

No capítulo 8, Ana Marusia Pinheiro Lima lança o olhar para longe da burocracia federal, examinando o papel de servidores em legislaturas 
locais na condução de "Parlamentos Mirins”, programas implementados por câmaras de vereadores em que crianças e adolescentes interpretam o papel de políticos. No único capítulo do livro baseado em um estudo de múltiplos casos (foram selecionados cinco programas após um levantamento mais amplo do universo), a autora analisa como essa agenda, aparentemente pouco contestatória, acaba avançando apenas em função da luta de servidores municipais que a interpretam como uma causa contenciosa. O foco deste capítulo são as estratégias que ativistas empregam para garantir a sobrevivência dos Parlamentos Mirins. A autora mostra que os defensores desses programas precisavam mobilizar recursos e redes de apoio tanto dentro do parlamento quanto em entidades externas, e manejar complexas relações hierárquicas entre burocratas e parlamentares.

O capítulo 9, de Paula Pompeu Fiuza Lima, apresenta o único caso incluído no livro em que os atores não identificavam sua agenda como uma causa contenciosa: a averiguação cadastral do Programa Bolsa Família (PBF). A inclusão desse estudo se provou útil para investigar a diferença entre ativismo e outras formas de ação criativa na burocracia. Enquanto alguns órgãos do governo federal passaram por um influxo de ativistas de movimentos sociais no início do governo Lula, o PBF se destacou pela alta qualificação técnica e pela ausência de participação social. Havia, no entanto, uma controvérsia importante no interior do PBF em torno da qual os atores se mobilizavam: qual erro cadastral deveria ser alvo central da averiguação, a inclusão indevida ou a exclusão indevida? Se, no primeiro momento, a pressão política para aumentar o número de beneficiários valorizava a preocupação com exclusões indevidas, em contextos de contenção de recursos e de fortalecimento das forças conservadoras, as acusações de fraude na inclusão se tornaram mais salientes. O foco do capítulo é em como, nesses contextos cambiantes, os atores experimentavam com diferentes soluções técnicas para garantir a legitimidade da averiguação cadastral.

A comparação entre esses últimos casos facilita pensar um pouco a diferença entre o ativismo institucional e outras formas de ação criativa. A ampla literatura sobre burocracia, especialmente a de nível de rua, já demonstra que empregados públicos exercem discricionariedade e agem a partir de valores (LIPSKY, 2010; MAYNARD-MOODY; MUSHENO, 2003; DUBOIS, 2010). A literatura sobre burocracia de médio escalão cita 
diversas práticas realizadas por esse tipo de trabalhador, como intermediar superiores, pares e subordinados; organizar e disseminar informações; negociar, lidar com conflitos, alocar recursos, entre outras (LOTTA; PIRES; OLIVEIRA, 2014, p. 472). Nos estudos apresentados aqui, todos envolvendo burocratas de médio escalão, também se encontram relatos de práticas semelhantes, independentemente da existência do que se demarcou como ativismo. Tanto os defensores do empoderamento das entidades de moradia (capítulo 7), quanto os técnicos do cadastro da Bolsa Família (capítulo 9) buscaram lidar com a diminuição de apoio político para suas agendas por meio de processos de experimentação criativa no desenho do programa. Isso sugere que nem sempre ativistas utilizam estratégias diferentes do que as empregadas por não ativistas, algo já detectado por Banaszak (2010).

Como o ativismo institucional se diferencia, então, de outras formas de ação criativa nas instituições? Novamente, a comparação do caso do Bolsa Família com outros exemplos pode ser de grande ajuda. Políticas públicas normalmente envolvem controvérsias (ZITTOUN, 2014). Uma causa pode ser entendida como um tipo específico de controvérsia, aquele que gira em torno de diferentes valores sobre estruturas institucionais de poder. Assim, pode-se dizer que, embora houvesse controvérsias em todos os casos, nem sempre elas poderiam ser tipificadas como causas. A controvérsia identificada por Paula Pompeu no capítulo 9 (entre priorizar evitar erros de inclusão versus erros de exclusão no momento da averiguação cadastral) não se trata de uma causa. Trata-se de uma controvérsia de ordem moral significativa, mas sua solução não passa por uma transformação fundamental na organização do poder. Curiosamente, os dois lados da controvérsia construíram justificativas em torno do que Boltanski e Thévenot (1999) entenderiam como uma mesma ordem de grandeza. Aqueles que defendiam a inclusão à base de autodeclaração valorizavam a criação de uma meta operacional que possibilitasse a maior cobertura do programa em menor tempo; já quem se preocupava em evitar inclusões indevidas justificava essa posição em termos de limitações de recursos: cada indivíduo incluído indevidamente estaria ocupando a vaga de outro que precisaria mais. A divergência não tinha a ver com diferentes entendimentos sobre as estruturas institucionais de poder, e sim sobre qual seria a lógica de custo e benefício mais adequada para garantir o mesmo resultado. 
De maneira diferente, o MCMV-E (capítulo 7) propôs reorganizar relações de poder na gestão pública ao empoderar entidades populares na implementação, algo que tem em comum com o PAA (capítulo 1) e com a agenda inclusiva de resíduos sólidos (capítulo 2). A implementação desses modelos alternativos implicaria então não somente em diferentes desenhos de políticas, mas também em mudanças de alocação de autoridade sobre a política. Essas propostas claramente podem ser entendidas como causas. Comparando os casos anteriormente citados ao do Bolsa Família, talvez não surpreenda que o trabalho "experimental” descrito por Pompeu pareça ser um processo de adaptação relativamente tranquilo em comparação com as lutas para transformar percepções sobre a natureza do bem público em que funcionários do MCMV-E se engajavam. Os defensores da causa autogestionária questionavam as próprias bases dos argumentos custo-benefício que prevalecem no serviço público e que foram usados para justificar modelos empresariais de produção de moradia. Para eles, o empoderamento de entidades populares seria mais importante do que a lógica da eficiência. Ou seja, a causa da autogestão envolveu lutas sobre a distribuição de poder e não apenas sobre o desenho adequado da política pública.

Na defesa de políticas mais contenciosas discutidas nesta seção (MCMV-E e os Parlamentos Mirins), os autores identificam duas estratégias distintas. Primeiro, os atores embarcaram na construção de redes mais amplas. Os atores que se organizaram para adaptar a averiguação do PBF se restringiam principalmente a um círculo fechado de técnicos. Nos casos do MCMV-E e dos Parlamentos Mirins, ganhar apoio para as políticas exigiu a construção de redes com atores em instituições mais diversas, como órgãos federais e subnacionais, no caso do MCMV-E, e entidades da sociedade civil no caso dos Parlamentos. Segundo, nesses dois estudos, os autores descrevem táticas em que os ativistas buscaram desarmar a própria natureza contenciosa do modelo de política proposto. Para o MCMV-E, isso envolveu a disseminação de novas ideias no interior da burocracia. No caso dos Parlamentos Mirins, demandou a busca por diversos patrocínios políticos para o programa, de maneira a desassociá-lo de um interesse político específico. 


\section{8. À procura do possível}

Nesta introdução, busquei apresentar um marco conceitual que foi desenvolvido com um grupo de estudantes do Programa de Pós-Graduação em Ciência Política da Universidade de Brasília ao longo de vários anos de debates. Se cada capítulo é de algum modo inspirado em uma proposta do conceito de ativismo institucional apresentado pela orientadora alguns anos atrás, cada autora e autor também ajudou a refinar e aprofundar esse conceito em um processo rico de construção coletiva. Esta introdução tentou repassar para o leitor o caminho percorrido, passando por teorias institucionalistas, a sociologia da ação, o pragmatismo, teorias de movimentos sociais, de políticas públicas e da burocracia. Esta busca por sintetizar teorias institucionalistas e de movimentos sociais não é só minha: outros autores vêm percebendo o potencial de melhor entender a relação entre ação e estrutura por meio do encontro entre várias perspectivas (MCADAM; SCOTT, 2005; SCHNEIBERG; LOUNSBURY, 2008; FLIGSTEIN; MCADAM, 2012). Essa bricolagem conceitual pode parecer um pouco dispersa, mas foi necessária para enfrentar o desafio de analisar um tipo de ação que não respeitava as fronteiras conceituais existentes.

Além de interpretar o passado, acredito que a perspectiva proposta aqui nos ajudará a pensar sobre o que pode acontecer na próxima fase histórica, já em curso no momento de publicação desta obra. A ideia central que tentei passar nesta introdução é que ativismo envolve buscar em contextos institucionais os recursos e relacionamentos que podem ser usados para avançar uma causa contenciosa. Se o contexto institucional é, na verdade, uma configuração relacional de atores, a mudança de contexto é uma mudança naquela configuração. Ao longo dos últimos anos, surgiram no Brasil novas organizações políticas à direita que mobilizam parte da população e que ganham cada vez mais acesso às instituições governamentais. Com a vitória da extrema direita nas urnas, o contexto mudou profundamente.

A mobilização de atores ideologicamente à direita deve também ser compreendida como ativismo. Causas contenciosas podem ser conservadoras, envolvendo não somente a defesa de mudança, mas a crítica a mudanças em curso ou propostas que podem reorganizar as relações de poder na sociedade. Como os estudos incluídos neste volume demostram, a luta pela 
ampliação de direitos e igualdade política e social já enfrentava oposição nas gestões anteriores. Embora os governos petistas tenham criado algumas oportunidades, a presença crescente de defensores de outros interesses e ideias na coalizão governamental significou que sempre foi necessário lutar para manter e avançar as políticas de inclusão e empoderamento de grupos marginalizados. A partir de 2019, as possibilidades de agir em prol dos direitos sociais e ambientais de dentro das estruturas burocráticas se tornou muito mais difícil.

Assim, este livro sai do prelo em um contexto completamente diferente daquele em que a pesquisa foi realizada, com boa parte das políticas públicas estudadas se encontrando hoje em processo de franco desmonte. Neste contexto, há duas questões centrais para acompanhar. Primeiro, em que medida ativismo institucional à direita se diferencia do ativismo em defesa da inclusão política e social? Segundo, como servidores públicos comprometidos com políticas de inclusão e direitos lidarão com o fortalecimento dos adversários no interior da burocracia federal? Sem dúvida, vive-se hoje em um período de retrocesso dessas agendas. No entanto, o estudo do ativismo é por natureza menos um rastreamento do provável do que uma procura do possível. Os radares continuarão ligados em busca do improviso inesperado.

\section{Referências}

ABERS, Rebecca Neaera; OLIVEIRA, Marília Silva. Nomeações políticas no Ministério do Meio Ambiente (2003-2013): interconexões entre ONGs, partidos e governos. Opinião Pública, v. 21, n. 2, p. 336-364, 2015.

ABERS, Rebecca Neaera; SERAFIM, Lizandra; TATAGIBA, Luciana. Repertórios de interação estado-sociedade em um Estado heterogêneo: a experiência na era Lula. Dados - Revista de Ciências Sociais, v. 57, n. 2, p. 325-357, 2014.

ABERS, Rebecca Neaera; SILVA, Marcelo Kunrath; TATAGIBA, Luciana. Movimentos sociais e políticas públicas: repensando atores e oportunidades políticas. Lua Nova: Revista de Cultura e Política, n. 105, p. 15-46, 2018. 
ANSELL, Chris. Ecological Explanation. In: BERK, Gerald; GALVAN, Dennis C.; HATTAM, Victoria (org.). Political Creativity: Reconfiguring Institutional Order and Change. Philadelphia: University of Pennsylvania Press, 2013. p. 55-77.

BANASZAK, Lee Ann. The women's movement inside and outside the State. [S.l.]: Cambridge University Press, 2010.

BERK, Gerald; GALVAN, Dennis. How people experience and change institutions: a field guide to creative syncretism. Theory and society, v. 38, n. 6, p. 543-580, 2009.

BOLTANSKI, Luc; THÉVENOT, Laurent. The Sociology of Critical Capacity. European Journal of Social Theory, v. 2, n. 3, p. 359-377, 1999.

BOURDIEU, Pierre. Outline of a theory of practice. Translated by Richard Nice. [S.l.]: Cambridge University Press, 1977.

CEFAÏ, Daniel. Como nos mobilizamos? A contribuição de uma abordagem pragmatista para a sociologia da ação coletiva. Dilemas: Revista de estudos de conflito e controle social, v. 2, n. 4, p. 11-48, 2009.

COLLIER, Ruth Berins; COLLIER, David. Shaping the political arena: critical junctures, the labor movement, and regime dynamics in Latin America. Princeton, NJ: Princeton University Press, 1991.

DAGNINO, Evelina; OLVERA, Alberto J.; PANFICHI, Aldo. Para uma outra leitura da disputa pela construção democrática na América Latina. In: DAGNINO, Evelina; OLVERA, Alberto J.; PANFICHI, Aldo (org.). A disputa pela construção democrática na América Latina. São Paulo: Paz e Terra, 2006. p. 13-92.

DAHL, Robert Alan. Who governs? Democracy and power in an American city. New Haven: Yale University Press, 1961.

DEWEY, John. Human Nature and Conduct. New York: The Modern Library, 1922.

DEWEY, John. How We Think. [S.l.]: Forgotten Books, 1933. 
DEWEY, John. Art as Experience. New York: Minton, Balch \&amp; Company, 1934.

DIANI, Mario. The concept of social movement. The sociological review, v. 40, n. 1, p. 1-25, 1992.

DIMAGGIO, Paul. Interest and agency in institutional theory. In: ZUCKER, Lynne G. (org.). Institutional patterns and organizations: culture and environment. Cambridge, MA: Ballinger Publishing Company, 1977. p. 3-32. DOWBOR, Monika. Arte da institucionalização: estratégias de mobilização dos sanitaristas (1974-2006). 2012. 288 f., il. Tese (Doutorado em Ciência Política) - Faculdade de Filosofia, Letras e Ciências Humanas, Universidade de São Paulo, São Paulo, 2012.

DUBOIS, Vincent. The bureaucrat and the poor: encounters in French welfare offices. London: Ashgate, 2010.

FLIGSTEIN, Neil; MCADAM, Doug. A theory of fields. New York: Oxford University Press, 2012.

GIDDENS, Anthony. The constitution of society: outline of the theory of structuration. [S.l.]: University of California Press, 1984.

GOLDSTONE, Jack A. Bridging institutionalized and noninstitutionalized politics. In: GOLDSTONE, Jack A. (org.). States, parties, and social movements. Cambridge, NY: Cambridge University Press, 2003. p. 1-24. GROSS, Neil. Charles tilly and American pragmatism. The American Sociologist, v. 41, n. 4, p. 337-357, 2010.

GUIGNI, Marco; PASSY, Florence. Contentious politics in complex societies: new social movements between conflict and cooperation. In: GIUGNI, Marco; MCADAM, Doug; TILLY, Charles (org.). From contention to democracy. Boulder: Rowman \& Littlefield, 1998. p. 81-108.

HALLETT, Tim; VENTRESCA, Marc J. Inhabited institutions: social interactions and organizational forms in Gouldner's Patterns of Industrial Bureaucracy. Theory and society, v. 35, p. 213-236, 2006. 
HOCHSTETLER, Kathryn; KECK, Margaret E. Greening Brazil: environmental activism in State and society. Durham and London: Duke University Press, 2007.

JASPER, James M. Emotions and social movements: twenty years of theory and research. Annual Review of Sociology, v. 37, n. 1, p. 285-303, 2011. JOAS, Hans. The creativity of action. Chicago: University of Chicago Press, 1996.

JOYCE, Mary C. Activism success: a concept explication. 2014. 107 f., il. Thesis (Master's degree) - Department of Communication, University of Washington, Washington, DC, 2014.

KINGDON, John W. Agendas, alternatives, and public policies. [S.l.]: Harper Collins College Publishers, 1995.

LAWRENCE, Thomas B.; SUDDABY, Roy; LECA, Bernard. Institutional work: actors and agency in institutional studies of organizations. Cambridge: Cambridge University Press, 2009.

LIPSKY, Michael. Street-Level Bureaucracy, 30th Anniversary Edition: Dilemmas of the Individual in Public Service. New York: Russell Sage Foundation, 2010.

LOTTA, Gabriela Spanghero; PIRES, Roberto Rocha C.; OLIVEIRA, Vanessa Elias. Burocratas de médio escalão: novos olhares sobre velhos atores da produção de políticas públicas. Revista do Serviço Público, v. 65, n. 4, p. 463-492, 2014.

MAHONEY, James. The legacies of liberalism: path dependence and political regimes in Central America. Baltimore: John Hopkins University Press, 2001.

MARQUES, Eduardo Cesar. Redes sociais e poder no Estado brasileiro: aprendizados a partir das políticas urbanas. Revista Brasileira de Ciências Sociais, v. 21, n. 60, p. 15-41, 2006. 
MAYNARD-MOODY, Steven Williams; MUSHENO, Michael Craig. Cops, teachers, counselors: stories from the front lines of public service. Ann Arbor: University of Michigan Press, 2003.

MCADAM, Doug. Recruitment to high-risk activism: the case of Freedom Summer. American journal of sociology, v. 92, n. 1, p. 64-90, 1986.

MCADAM, Doug; MCCARTHY, John D.; ZALD, Mayer N. Introduction: Opportunities, mobilizing structures, and framing processes - toward a synthetic, comparative perspective on social movements. In: MCADAM, Doug; MCCARTHY, John D.; ZALD, Mayer N. (org.). Comparative perspectives on social movements: political opportunities, mobilizing structures, and cultural framings. New York: Cambridge University Press, 1996. p. 1-22.

MCADAM, Doug; SCOTT, W. Richard. Organizations and Movements. In: DAVIS, Gerald F. et al. (org.). Social movements and organization theory. New York: Cambridge University Press, 2005. p. 4-40.

MCADAM, Doug; TARROW, Sidney G.; TILLY, Charles. Dynamics of contention. Cambridge: Cambridge University Press, 2001.

MCCARTHY, John D.; ZALD, Mayer N. Resource mobilization and social movements: a partial theory. American journal of sociology, v. 82, n. 6 , p. 1212-1241, 1977.

MELUCCI, Alberto. Nomads of the present. Philadelphia: Temple University Press, 1989.

MELUCCI, Alberto. Challenging codes: collective action in the information age. [S.l.]: Cambridge University Press, 1996.

MEYER, David S. Social movements and public policy: eggs, chicken, and theory. In: MEYER, David S.; JENNESS, Valerie; INGRAM, Helen M. (org.). Routing the opposition: social movements, public policy, and democracy. Minneapolis: University of Minnesota Press, 2005. p. 1-26. 
OLIVEIRA, Marília Silva de. Movimento para as instituições: movimento ambiental, partidos políticos e a liderança de Marina Silva. 2016. 303 f., il. Tese (Doutorado em Ciência Política) - Instituto de Ciência Política, Universidade de Brasília, Brasília, 2016. OLSON, Mancur. The logic of collective action: public goods and the theory of groups. Cambridge, MA: Harvard University Press, 1965.

OLSSON, Jan. Subversion in institutional change and stability: a neglected mechanism. London: Palgrave Macmillan, 2016.

OLSSON, Jan; HYSING, Erik. Theorizing inside activism: understanding policymaking and policy change from below. Planning theory \& practice, v. 13, n. 2, p. 257-273, 2012.

PETTINICCHIO, David. Institutional activism: Reconsidering the insider/ outsider dichotomy. Sociology compass, v. 6, n. 6, p. 499-510, 2012.

RICH, Jessica A. J. Grassroots bureaucracy: intergovernmental relations and popular mobilization in Brazil's AIDS policy sector. Latin American politics and society, v. 55, n. 2, p. 1-25, 2013.

SANTORO, Wayne A.; MCGUIRE, Gail M. Social movement insiders: the impact of institutional activists on Affirmative Action and comparable worth policies. Social problems, v. 44, p. 503-519, 1997.

SCHNEIBERG, Marc; LOUNSBURY, Michael. Social movements and institutional analysis. In: GREENWOOD, Royston et al. (org.). The sage handbook of organizational institutionalism. Thousand Oaks, CA: Sage, 2008. p. 648-670.

SKOCPOL, Theda; RUESCHEMEYER, Dietrich; EVANS, Peter B. (org.). Bringing the State back in. [S.l.]: Cambridge University Press, 1985.

SEWELL JR, William H. A theory of structure: duality, agency, and transformation. American journal of sociology, v. 98, p. 1-29, 1992. 
SILVA, Marcelo Kunrath. Espaços e Repertórios: a atuação dos movimentos sociais através das fronteiras da sociedade civil e do Estado. In: SCHERER-WARREN, Ilse; LÜCHMANN, Lígia Helena H. (org.). Movimentos sociais e engajamento político: trajetórias e tendências analíticas. Florianópolis: Editora UFSC, 2015. p. 133-160.

SNOW, David A. et al. Frame alignment processes, micromobilization, and movement participation. American sociological review, v. 51, n. 4, p. 464-481, 1986.

SNOW, David A.; ZURCHER JR, Louis A.; EKLAND-OLSON, Sheldon. Social networks and social movements: a microstructural approach to differential recruitment. American sociological review, p. 787-801, 1980.

TARROW, Sidney G. Power in movement: social movements, collective action and politics. Cambridge: Cambridge University Press, 1994.

TATAGIBA, Luciana; ABERS, Rebecca; SILVA, Marcelo Kunrath. Movimentos sociais e políticas públicas: ideias e experiências na construção de modelos alternativos. In: PIRES, Roberto Rocha C.; LOTTA, Gabriela Spanghero; OLIVEIRA, Vanessa Elias (org.). Burocracia e políticas públicas no Brasil: intersecções analíticas. Brasília: Enap/Ipea, 2018. p. 105-138. TILLY, Charles. From mobilization to revolution. Reading, MA: Addison-Wesley Pub. Co., 1978.

TILLY, Charles. Contentious performances. [S.l.]: Cambridge University Press, 2008.

TOURAINE, Alain. La voix et le regard. Paris: Les Édition du Seuil, 1978. YIN, Robert K. Case study research: design and methods. London: SAGE, 1984. ZITTOUN, Philippe. The political process of policymaking: a pragmatic approach to public policy. [S.l.]: Springer, 2014. 


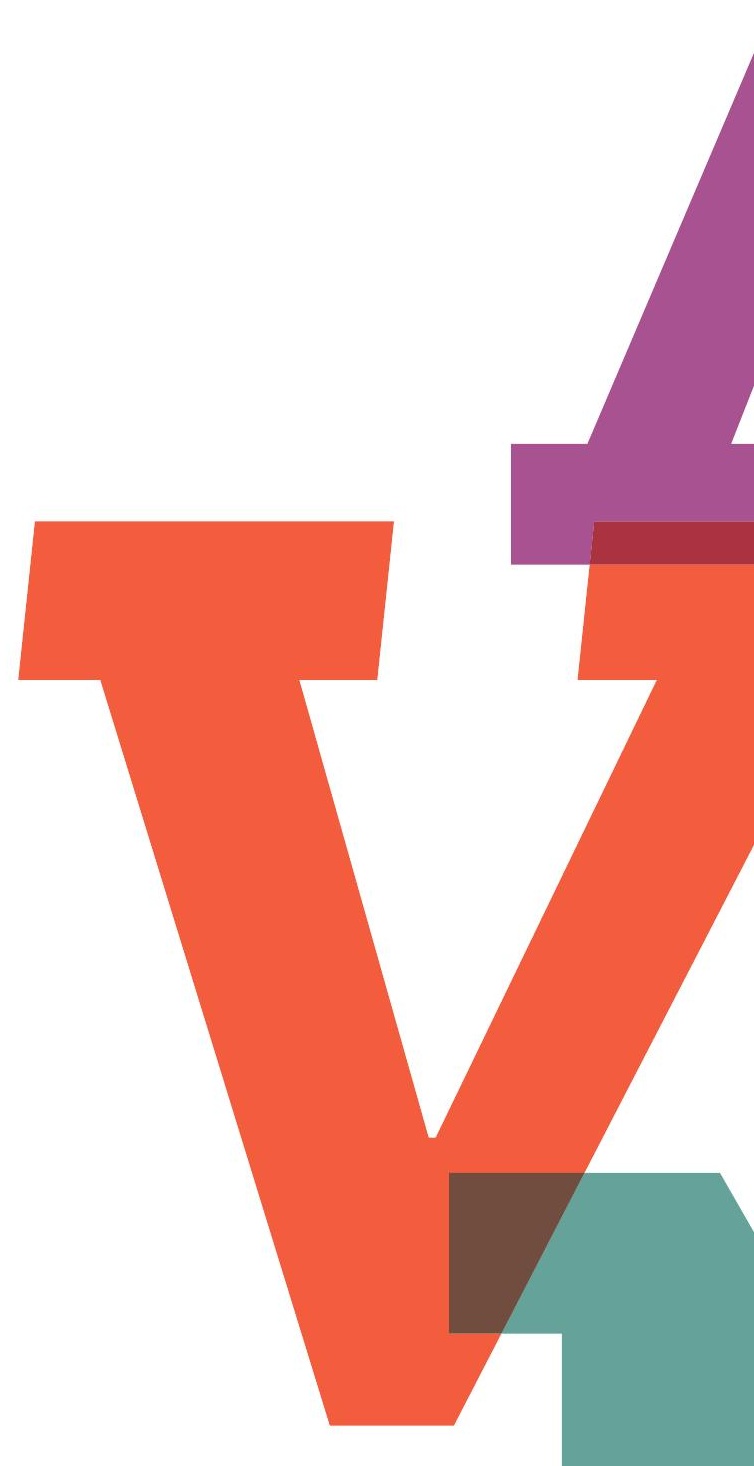




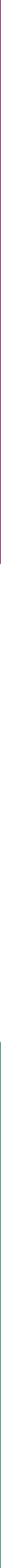




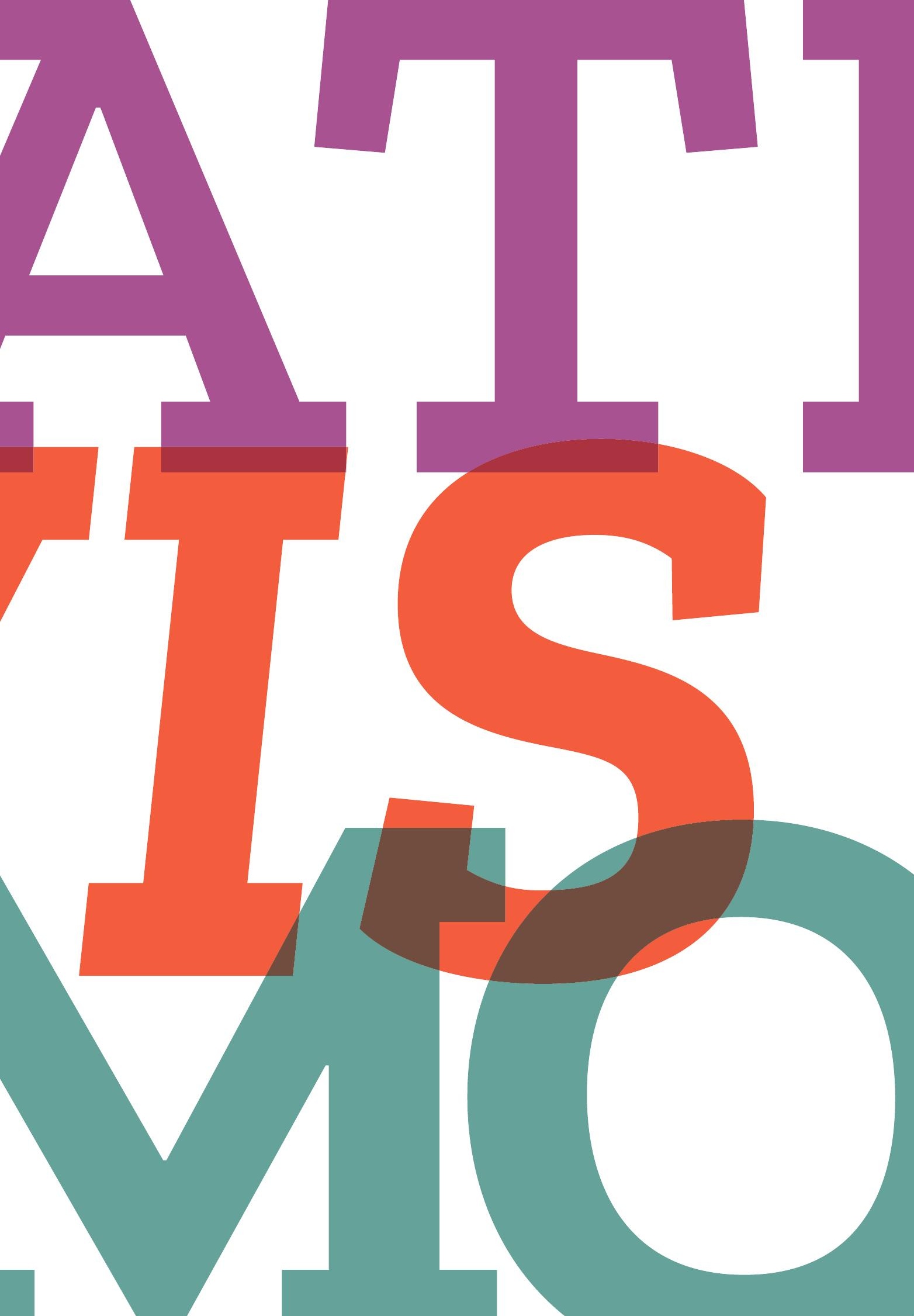




\section{Capítulo 1}

\section{Ativismo institucional e enquadramentos interpretativos: discutindo as causas do ativismo de burocratas na criação do programa de aquisição de alimentos}

Lucas Alves Amaral

O objetivo deste capítulo é descrever e analisar a relação entre práticas de ativismo institucional no âmbito do Programa de Aquisição de Alimentos (PAA) e as ideias que mobilizam tais práticas, o que Abers, na introdução deste livro, chama de causas contenciosas. Para a autora, causas são objetivos que são defendidos contra algo (opositores, uma ordem institucional, um contexto político, etc.), seja para provocar mudanças, seja para garantir a manutenção de ordens institucionais. O meu argumento central neste texto é de que determinadas causas que orientam a ação contestatória do ativismo 
institucional devem ser vistas por meio do conceito de enquadramentos interpretativos, conceito que pode ser compreendido introdutoriamente como: "conjuntos de significados e crenças orientados à ação" (BENFORD; SNOW, 2000, p. 614, tradução nossa). ${ }^{1}$ De antemão, esse conceito nos ajuda a entender o como atores realizam agências situadas orientados por ideias e percepções da realidade institucional em que estão inseridos.

Nas ciências sociais, o conceito de enquadramentos interpretativos, oriundo do interacionismo simbólico de Erving Goffman (1974, 2012), ganhou destaque nos estudos de movimentos sociais, principalmente com Benford e Snow (2000), como forma de elucidar de que maneira ações coletivas constroem sistemas organizados de princípios para orientar sua ação (na gestão da linguagem, na comunicação de suas lutas políticas, na orientação estratégica de repertórios de ação, etc.) (OLIVEIRA, 2015). Deslocar o olhar para como ativismos que não ocorrem no âmbito de movimentos sociais, mas no interior de instituições do Estado, orientam-se por enquadramentos interpretativos nos parece uma estratégia coerente com a operacionalidade do conceito de ativismo institucional, já que este subverte a classificação da literatura sobre institucionalização e contestação.

Classicamente, a contestação era uma prática prevista para movimentos sociais, havendo uma separação dos espaços dos movimentos sociais e dos espaços dos atores da política institucional, entre eles, os burocratas (RECH; SILVA, 2016). Acoplar o “ativismo”, que é uma prática de agentes na defesa de causas, ao "institucional”, que é uma localização e um posicionamento dos agentes nas instituições políticas é, portanto, um grande ganho analítico na discussão sobre a complexidade das dinâmicas entre Estado e sociedade civil. O mesmo, a meu ver, pode ocorrer com a operacionalização do conceito de enquadramentos interpretativos na análise do ativismo institucional de burocratas, o que busco realizar aqui. ${ }^{2}$

O estudo de caso sobre a criação do PAA me levou a procurar quais as causas defendidas pelos burocratas que exerceram ativismo institucional na criação do programa, de onde se originaram essas causas e como tais causas

1 “[...] action-oriented sets of beliefs and meanings.” (BENFORD; SNOW, 2000, p. 614).

2 Esta proposta foi mais densamente desenvolvida em minha tese de doutorado (AMARAL, 2018). 
funcionavam como orientadoras de uma ação fundamental, criar o programa. $\mathrm{O}$ conceito de enquadramentos interpretativos me ajudou a sistematizar as ideias que funcionavam como causas que estes atores pareciam defender: o que chamo de enquadramentos do fortalecimento da agricultura familiar (FAF) e do fortalecimento da segurança alimentar (FSAN), como será visto a seguir.

Para descrever esses enquadramentos e as práticas de ativismo ancoradas neles na criação do PAA, exponho e analiso neste capítulo informações coletadas do estudo de caso sobre o ativismo institucional praticado no arranjo político-institucional ${ }^{3}$ do Programa de Aquisição de Alimentos. Foco em seu processo de criação, momento em que o contexto político favoreceu a ocupação de cargos na burocracia federal por atores diversos, técnicos oriundos de organizações da sociedade civil, partidários do Partido dos Trabalhadores (PT) ou de partidos coligados ao PT e, no caso do PAA, principalmente, acadêmicos e gestores públicos atuantes outrora em políticas locais relacionadas com o programa. Na análise empreendida foram utilizadas 21 entrevistas, realizadas entre 2015 e 2016, com burocratas que atuaram no Ministério do Desenvolvimento Social (MDS), na Companhia Nacional de Abastecimento (Conab), no Ministério de Desenvolvimento Agrário (MDA) e com representantes de organizações da sociedade civil atuantes no Conselho Nacional de Segurança Alimentar e Nutricional (Consea) até 2016. ${ }^{4}$

\section{Ativismo institucional, causas e enquadramentos interpretativos}

A partir da atuação de seus partidários “dentro do Estado”, movimentos sociais agem estrategicamente dentre uma miríade de repertórios de ação na ocupação de cargos burocráticos, exercendo ativismos em prol de suas causas coletivas (SANTORO; MCGUIRE, 1997; ABERS; SERAFIM;

3 Entendo o "arranjo político-institucional” como “o conjunto de regras, mecanismos e processos que define a forma particular como se coordenam atores e interesses na implementação de uma política pública específica” (PIRES; GOMIDE, 2016, p. 8).

${ }^{4}$ O marco temporal se dá devido ao impeachment da ex-presidenta Dilma Rousseff (PT), processo que reconfigurou o arranjo político-institucional do programa e a própria política nos anos seguintes. 
TATAGIBA, 2014). Assim, na trajetória do conceito de ativismo institucional, o termo foi usado para "descrever o que pessoas fazem quando assumem cargos em burocracias governamentais com os propósitos de fazer avançar agendas políticas ou projetos propostos por movimentos sociais” (ABERS; TATAGIBA, 2015, p. 73, tradução nossa). ${ }^{5}$ No entanto, alguns autores no Brasil, em especial Abers (2015, 2018, neste livro), vêm problematizando o conceito para além do vínculo de ativistas com movimentos sociais, demonstrando que o ativismo institucional diz respeito a ações que partem de compromissos com causas coletivas. Isso quer dizer que mesmo que movimentos sociais possam ter influência na produção histórica das causas que produzem ativismo institucional, nem sempre ativistas institucionais são ou foram membros desses movimentos. Abers (2015), por exemplo, mostra que a atuação ativista de burocratas no Programa Bolsa Verde aponta para a adesão desses atores às causas ambientalistas que tangenciam o Programa e não necessariamente para sua participação prévia ou simultânea em movimentos ambientalistas.

Esses achados me levaram a perceber que o ativismo institucional de burocratas no estudo de caso sobre o PAA mobilizava causas coletivas oriundas de ideias produzidas historicamente de modo complexo e de modo interativo por múltiplos atores e fontes (acadêmicos, partidos, documentos, estudos, outras políticas públicas e, também, movimentos sociais). A princípio, tais causas pareceram dificilmente sistematizáveis, já que não estavam necessariamente atreladas ao vínculo dos sujeitos que as defendiam a movimentos sociais, embora - no caso do PAA - alguns movimentos populares tenham colaborado historicamente na produção dessas ideias que se transformaram em causas. $\mathrm{O}$ conceito de enquadramentos interpretativos, então, permitiu-me sistematizar as principais ideias orientadoras dessas causas e entender as práticas de ativismo institucional no PAA. Enxergo o ativismo institucional, portanto, como um tipo particular de ação que envolve “a perseguição de oportunidades para defender

5 “[...] to describe what people are doing when they take jobs in government bureaucracies with the purpose of advancing the political agendas or projects proposed by social movements.” (ABERS; TATAGIBA, 2015, p. 73). 
causas contenciosas” (ABERS, 2019, p. 21, tradução nossa). ${ }^{6}$ Na versão do conceito que aqui utilizo, burocratas podem realizar práticas de ativismo por meio de "compromissos individualizados” (ABERS, 2015), ${ }^{7}$ embora suas causas se refiram a ideias produzidas historicamente de modo coletivo.

Ao refletir sobre a associação entre ativismo institucional, causas e enquadramentos interpretativos busquei contribuições teóricas que problematizassem a relação entre ideias e ação institucional, as quais apresento e discuto adiante. Os conceitos a seguir são elos importantes para a proposta teórica que guia minhas análises.

Em primeiro lugar, segundo Hay (2008) e Schmidt (2008), expoentes do institucionalismo construtivista, os sujeitos inseridos em instituições devem ser considerados agentes complexos que, ao mesmo tempo, são transformados e transformam as instituições em que estão inseridos. Esses sujeitos são estratégicos nas suas ações institucionais, visando realizar objetivos complexos, contingentes e constantes. Na realização de objetivos, alguns contextos favorecem determinadas estratégias em relação a outras, por isso é importante estar atento aos contextos em que os atores estão inseridos, como no caso da criação do PAA: o primeiro mandato do ex-presidente Luís Inácio “Lula” da Silva (PT), considerado um momento de alto influxo de sujeitos oriundos da sociedade civil (de fora) para dentro do Estado (D’ARAÚJO, 2007).

Para Hay (2008) e Schmidt (2008), os atores elaboram percepções dos contextos que embora sejam sempre incompletas são frutos das ideias que os orientam normativamente sobre seus modos de agir, a partir do que entendem o que "deveria ser”, produzir “ordem” ou "transformação”. Mas como são produzidas essas ideias? Elas advêm das orientações normativas dos atores e de suas noções sobre quais estratégias de ação tomar em contextos incompletos. Dito isso, é preciso compreender, além das ideias que orientam as ações, o que é a ação institucional dos atores propriamente dita. Nesse sentido, a definição de agência de Emirbayer e Mische (1998) me parece uma contribuição relevante. Segundo os autores, a agência é

6 “[...] pursuit of opportunities to defend contentious causes.” (ABERS, 2019, p. 21).

7 A autora toma o conceito de Lichterman (1995). 
Um engajamento temporalmente construído por atores de diferentes ambientes estruturais, os quais, por meio da interação entre hábito, imaginação e julgamento, tanto reproduzem, quanto transformam tais estruturas em resposta interativa aos problemas colocados pelas situações históricas mutantes. (EMIRBAYER; MISCHE, 1998, p. 970, tradução nossa). ${ }^{8}$

Os autores apontam que a agência tem três dimensões e todas são igualmente relevantes. São elas: a dimensão deliberativa, a reprodutiva e a projetiva. Assim, a agência que promove a mudança ou a manutenção institucional não deve ser vista somente na ótica de uma mudança radical e advinda de crises, mas também na ótica de ações que promovem pequenas mudanças paulatinas e incrementais, ou da agência que se configura como inação e até mesmo como resistência estratégica à mudança. Para Emirbayer e Mische, a agência no âmbito das instituições deve ser compreendida, portanto, a partir da variável "tempo" (passado, presente e futuro), podendo ela ser classificada como: $i$ ) reprodutiva, definida por orientações do passado por meio do hábito; ii) deliberativa, por partir de julgamentos e deliberações sobre o presente em relação ao passado; ou iii) projetiva, já que parte de julgamentos e projeções para o futuro a partir de questionamentos das continuidades entre passado e presente.

Em terceiro lugar, Bevir e Rhodes (2006) complementam a noção de agência apresentada anteriormente ao produzir reflexões sobre as diferenças entre agência e autonomia. Para eles, os sentidos e os significados das ações dos atores sociais emergem das instituições em que estão inseridos. Dessa forma, a agência não necessariamente se confunde com a noção de autonomia dos atores em relação a essas instituições, nem sequer se distancia totalmente delas. Indivíduos autônomos podem ter experiências, razões e adotar crenças e ações fora de todos os contextos em que estão

8 "The temporally constructed engagement by actors of different structural environments... which, through the interplay of habit, imagination, and judgment, both reproduces and transforms those structures in interactive response to the problems posed by changing historical situations.” (EMIRBAYER; MISCHE, 1998, p. 970). 
inseridos. Por outro lado, atores podem apenas agir e dar razão a novas formas sociais em relação às instituições em que estão inseridos, fazendo isso unicamente em interação com seu posicionamento nessas instituições. Assim, os autores definem o conceito de agência como "agência situada". A partir do exposto, afirmo que é possível definir ativismo institucional como um tipo de agência situada (BEVIR; RHODES, 2006) que é influenciada pela variável tempo (EMIRBAYER; MISCHE, 1998), ou seja, pode ser projetiva, deliberativa e reprodutiva.

Por fim, agrego ao modelo teórico até aqui discutido o próprio conceito de enquadramento interpretativo, que é mais consistente do que o simples termo “ideias” discutido por Hay (2008) e Schmidt (2008), conforme citado anteriormente. A intenção de agregá-lo busca identificar quais ideias orientam esta agência situada que é o ativismo institucional. Destarte, o conceito de enquadramentos interpretativos, agora de modo mais amplo, pode ser elaborado assim: sistemas cognitivos e normativos coerentes que definem pontos de vista, mecanismos de formação de identidade, princípios de ação, prescrições metodológicas e práticas para sujeitos em contextos específicos (SUREL, 2000; MENDONÇA; SIMÕES, 2012; NUNES, 2013; OLIVEIRA, 2015). Agrega-se a essa definição o que Benford e Snow (2000) sugerem em relação às três etapas constituintes de enquadramentos interpretativos: i) o diagnóstico e a construção do problema; ii) a proposição de soluções; e iii) a organização de ações e de engajamento orientada para a resolução do problema e operação das soluções. A meu ver, a partir dessa exposição, os enquadramentos interpretativos podem ter a função de inspirar e legitimar agências situadas se os utilizamos na análise do ativismo institucional. Para identificá-los é preciso observar as três etapas propostas por Benford e Snow - em primeiro lugar, o problema e as soluções -, e analisar como se dá a última delas, que pode ser entendida como uma agência situada quando aplicada a burocratas atuando como ativistas institucionais. 


\section{Ativismo institucional em prol do fortalecimento da agricultura} familiar e do fortalecimento da segurança alimentar: a criação do PAA

Segundo Grisa e Trinches (2015), o Programa de Aquisição de Alimentos (PAA) introduziu no Brasil uma nova lógica no campo das políticas de agricultura familiar e de segurança alimentar por meio da revisão do papel das compras governamentais como instrumento de incentivo à construção de reserva de mercado para pequenos produtores brasileiros, e, simultaneamente, com foco na destinação desses alimentos para melhoria da qualidade da alimentação de público vulnerável em termos de segurança alimentar e nutricional. É possível afirmar, portanto, que o PAA é organizado por problemas e soluções de dois enquadramentos interpretativos fundamentais: o fortalecimento da agricultura familiar (FAF) e o fortalecimento da segurança alimentar e nutricional (FSAN). A criação do PAA, que, como será visto, envolve ativismo institucional de burocratas, pode ser vista como o resultado de engajamento orientado para resolução do problema e operação das soluções do FAF e do FSAN.

Se buscamos resgatar interações históricas que produziram o enquadramento do FAF encontramos que este se ancora em lutas de organizações da sociedade civil e movimentos sociais agrários desde a década de 1970, bem como em estudos acadêmicos e produção de documentos diversos e experiências de políticas locais nas décadas seguintes. O FSAN, por sua vez, tem suas raízes em movimentos sociais e, principalmente, em produções técnicas e acadêmicas sobre a fome no Brasil. Embora as interações que produziram o FSAN fossem independentes do FAF, ambos se entrecruzaram na década de 1990. Já na década de 2000, uma conjunção de fatores levou acadêmicos, políticos do Partido dos Trabalhadores, gestores públicos locais e representantes de organizações da sociedade civil a se mobilizarem em torno de debates em prol da união das soluções dadas aos problemas oriundos desses dois enquadramentos interpretativos, o que culminou na construção do Programa Fome Zero, ${ }^{9}$

9 Conti (2016, p. 73) aponta que o Projeto Fome Zero quando foi assumido como programa de governo passou a ser chamado Programa Fome Zero e, posteriormente, assumiu a 
no âmbito do Instituto Cidadania. ${ }^{10} \mathrm{~A}$ oportunidade política do contexto de disputa eleitoral que o PT viveria com a candidatura de Lula em 2002 contribuiu para formação de alianças entre diferentes atores e possibilitou a formalização do Fome Zero, de onde são retiradas as principais referências do PAA. Sujeitos diversos, principalmente acadêmicos participantes desse processo, vieram a ocupar cargos na burocracia federal do primeiro mandato presidencial do PT em 2003.

\section{O fortalecimento da agricultura familiar}

No Brasil, o fomento e estruturação da produção da agricultura familiar, bem como a atenção à promoção de boa qualidade alimentar e nutricional da população, foram temas historicamente relegados a segundo plano pelas políticas públicas. Por um lado, foram negligenciados diante da lógica econômica de modernização conservadora da agricultura nacional; por outro, foram relegados dadas as condições socioculturais e políticas da realidade brasileira, marcada por desigualdade social, altos índices de pobreza e orientação da discussão do tema da alimentação a partir do caráter assistencial e emergencial da fome. Segundo Grisa e Schneider (2015), as políticas para a agricultura até a década de 1970 foram marcadas por uma estratégia nacional-desenvolvimentista na tentativa dos governos de construir a economia nacional. Já na década de 1960, essa estratégia começou a apresentar sintomas de crise, observada nas dificuldades no abastecimento alimentar da população, além de aumento da inflação, e no

identidade de estratégia Fome Zero "por entender-se que se tratava de uma estratégia de governo distinta dos programas que a compunham”. Chamo o Fome Zero de Programa ou apenas de Fome Zero ao longo deste texto. Entendo que os enquadramentos do FAF e FSAN foram acoplados formalmente neste documento.

${ }^{10}$ INSTITUTO CIDADANIA. Projeto Fome Zero: uma proposta de política de segurança alimentar para o Brasil. São Paulo: Instituto Cidadania, 2001. 
esgotamento da capacidade de importar bens necessários à industrialização do País (que, por sua vez, demandava investimentos em exportações para criar divisas) e [...] na emergência de críticas ao padrão dependente e excludente seguido pela industrialização. (GRISA; SCHNEIDER, 2015, p. 129).

Em resposta a essa crise, o governo militar introduziu no país a estratégia de modernização tecnológica da agricultura, privilegiando os grandes produtores e relegando os pequenos à marginalidade.

O fim da ditadura militar, que se configurou na reorganização do território brasileiro e na intensificação da participação dos movimentos sociais na esfera pública, trouxe novas demandas e novos atores para a cena da agricultura brasileira. Destacam-se a mobilização da sociedade civil a favor da reforma agrária durante a Assembleia Constituinte por meio da "Campanha Nacional pela Reforma Agrária”, o Movimento dos Sem Terra (MST), o Movimento dos Atingidos por Barragens (MAB), o Movimento dos Pequenos Agricultores (MPA), o Movimento de Mulheres Trabalhadoras Rurais (MMTR), a Confederação Nacional dos Trabalhadores da Agricultura (Contag), a Comissão Pastoral da Terra (CPT) e a Federação de Órgãos para Assistência Social Educacional (Fase), o Instituto Brasileiro de Análises Sociais e Econômicas (Ibase), criado em 1971 e que participou ativamente da campanha "Ação da Cidadania contra a Fome, a Miséria e pela Vida”, liderada pelo sociólogo Herbert de Souza, o "Betinho" (DELGADO, 2010; OLIVEIRA, 2015).

Na década de 1980, a medida governamental orientadora para a agricultura nacional foi a Política de Garantia de Preços Mínimos (PGPM), que visava estabilizar os preços dos alimentos para os consumidores e garantir a renda para os agricultores por meio do uso de estoques públicos. Novas demandas por políticas que não visassem apenas créditos ou regulação dos preços começaram a surgir no cenário social. Assim, desde os anos 1980, reações e reivindicações de movimentos sociais foram frequentes e incisivas em torno de melhores condições de vida e da bandeira da reforma agrária no país. Demandavam-se políticas diferenciadas de crédito e de assistência técnica e legislação trabalhista a favor dos pequenos produtores (GRISA, 2012; GRISA; SCHNEIDER, 2015; PORTO, 2014). 
A década de 1990 foi marcada por uma política governamental menos interventora nos mercados agrícolas. A partir do governo Collor e, em seguida, nos governos Itamar Franco e Fernando Henrique Cardoso, reformas administrativas e privatizações deram o tom da intervenção do governo no país. Nesse contexto, uma série de órgãos reguladores foram extintos e o volume de crédito rural concedido à agricultura nacional foi tímido e constante. Foi nessa conjuntura que surgiu a Companhia Nacional de Abastecimento (Conab), uma das principais executoras do PAA.

Simultaneamente, alguns conflitos fundiários ocorreram com violência pelo Brasil, entre eles, os eventos que resultaram numa série de mortes no confronto entre trabalhadores Sem Terra e policiais militares. Em decorrência desses eventos, várias reivindicações e contestações da sociedade civil passaram a gerar pressão sobre o governo federal em prol de políticas de crédito, melhoria de preços e incentivos à comercialização (GRISA; SCHNEIDER, 2015); entre elas, reinvindicações anuais chamadas de "Grito da Terra”. O Grito da Terra se tornou um evento anual de mobilizações de todos os movimentos sociais agrários do país que passaram a exigir políticas específicas para a "agricultura familiar” - categoria que ganha ressonância social.

No contexto de produção de ações e ideias dos movimentos sociais, o conceito de agricultura familiar ganhou destaque em produções acadêmicas nacionais e internacionais, reunindo os atores sociais do campo em torno de suas agendas políticas. ${ }^{11}$ Com ele, o marco de abordagem sobre a pequena produção no Brasil é transformado. Antes, as produções acadêmicas em geral tendiam a enxergar os pequenos produtores (ou campesinato) como um segmento subdesenvolvido dentro do sistema de desenvolvimento econômico nacional - o que identificamos como o "problema” do enquadramento interpretativo do FAF. A categoria "agricultura familiar”, ao contrário, tende a considerar os aspectos positivos do segmento, tais como seu papel de "significativo desenvolvimento da produção de alimentos no

${ }^{11}$ Segundo Picolloto (2014, p. 67), uma pesquisa inovadora produzida em articulação com a Confederação Nacional dos Trabalhadores na Agricultura (Contag) por José Graziano da Silva e uma equipe de pesquisadores no final da década de 1970 foi muito relevante na contribuição acadêmica da importância da pequena produção no Brasil. 
Brasil e em grande parte do mundo desenvolvido” (PICOLOTTO, 2014, p. 68). A categoria faz parte da solução encontrada na organização do FAF.

Várias pesquisas acadêmicas sobre a agricultura familiar no Brasil passaram a ser nomeadas sob o rótulo de "Sociologia do Novo Rural", deslocando referências setoriais anteriores que confundiam agricultura com grande produção e monocultura. No debate acadêmico, por meio de pesquisas e produções em rede com organismos governamentais e internacionais, argumentou-se que a agricultura familiar tinha um papel importante no desenvolvimento nacional. A categoria também foi mobilizada por atores sociais, principalmente pelo sindicalismo dos trabalhadores rurais; e foi, ainda, utilizada em ações do Estado por meiode políticas públicas (PICOLOTTO, 2014), tal como o Programa de Fortalecimento da Agricultura Familiar (Pronaf). O Pronaf é uma política

destinada a fornecer créditos com baixa taxa de juros de custeio e investimento aos agricultores familiares ou suas organizações, ficando sua execução a cargo, basicamente, de bancos públicos federais, com destaque ao Banco do Brasil. (OLIVEIRA, 2015, p. 33).

Observa-se que ideias sobre a solução dos problemas da agricultura familiar vão sendo elaboradas, entre elas o fornecimento de créditos para pequenos produtores. No entanto, as soluções não param por aí.

Müller (2007) aborda experiências de compras públicas da agricultura familiar na década de 1990 desenvolvidas por prefeituras governadas pelo PT - em especial, Belo Horizonte e Porto Alegre - que ofereceram um novo modelo de solução ao problema do FAF: a garantia de mercado para agricultores familiares. Aliás, já na década de 1980 no estado de São Paulo uma experiência de compra pública da agricultura familiar com destinação a merenda escolar também foi realizada no governo Franco Montoro.

Assim, o enquadramento dado à agricultura familiar no Brasil anteriormente ao PAA vai construindo soluções, tal como a demanda dos movimentos sociais por políticas públicas predominantemente crediárias e compensatórias. A produção interativa que ocorre nas lutas sociais, nos debates acadêmicos surgidos na década de 1980 e nas políticas implementadas na década de 1990, engendra o enquadramento do FAF, acrescentando outras ideias às 
soluções como, por exemplo, a garantia de mercado, mas, principalmente, o incentivo ao associativismo e à valorização dos modos de vida dos agricultores familiares, conclusão advinda das entrevistas que realizei. Inclui-se ao FAF a noção de que fortalecer a agricultura passa por construir condições de autonomia e "empoderamento" para os pequenos agricultores familiares.

Dito isso, a partir dos processos interativos apresentados, é possível afirmar que o conjunto de ideias acadêmicas, o surgimento do Pronaf, as iniciativas de movimentos sociais e organizações da sociedade civil, bem como as iniciativas de compras públicas da agricultura familiar na década de 1990 contribuíram para a construção dos princípios organizadores de ação que sustentam o enquadramento interpretativo do FAF. Após esforço de sistematização, defendo que as ideias-chave (ou seja, as soluções apresentadas ao problema da agricultura familiar no Brasil) deste enquadramento são: i) foco na "produção" de alimentos como resposta à vulnerabilidade e à marginalização histórica dos agricultores familiares; ii) o incentivo aos “modos de vida comunitária”, ou seja, a organização dos agricultores familiares por meio de associações e cooperativas, bem como a sua "participação política”; iii) as garantias de crédito e de mercado como soluções prioritárias para os problemas da agricultura familiar no Brasil. Para colocar tais soluções em prática, ações estratégicas passam a ser fundamentais, a principal delas, a criação de políticas públicas que contribuam para a realização das ideias-chave apresentadas anteriormente. É aí que a luta por criar o PAA se encaixa como estratégia de ação orientada pelo enquadramento do FAF, principalmente pelas ideias-chave 1 e 2 expostas anteriormente.

\section{O fortalecimento da segurança alimentar e nutricional}

O enquadramento do FSAN, por sua vez, pode ter sua construção histórica situada nas décadas de 1980 e 1990, por meio de uma série de interações mediadas por contribuições acadêmicas, estudos sobre a fome no Brasil e, principalmente, pela interação entre organizações da sociedade civil por meio da "Ação da Cidadania Contra a Fome”, do Fórum Brasileiro de Segurança Alimentar e Nutricional (uma rede de organizações da sociedade civil), das universidades e de partidos políticos, em especial, o 
PT. Inicialmente, o principal problema do FSAN foi a fome no Brasil. Até a década de 1980, a temática da alimentação era debatida a partir da escassez de alimentos que grupos sociais sofriam no país. Discutia-se, portanto, se a produção nacional seria suficiente para alimentar a nação. Percebe-se, desde aí, um cruzamento entre os problemas da fome e da agricultura no país, e esta última (embora geralmente oriunda de grandes proprietários) despontava como uma resposta para a fome nacional.

Grisa (2012) aponta que a segurança alimentar e nutricional se tornou um referencial setorial de política pública no Brasil no governo Sarney por meio do documento "Segurança Alimentar: proposta de uma política contra a fome”, elaborado por uma equipe de técnicos a convite da Superintendência de Planejamento do Ministério da Agricultura. Conti (2016), por sua vez, assinala que a partir da década de 1980 organizações sociais e acadêmicos produziram uma pesquisa cujos principais resultados foram publicados na obra "Raízes da fome” (MINAYO, 1985). Em 1986 foi realizada a $1^{\text {a }}$ Conferência Nacional de Alimentação e Nutrição em conjunto com a $8^{\text {a }}$ Conferência Nacional de Saúde, com participação ativa da sociedade civil e instituições governamentais. Como resultado, foi gerado o documento "Política Nacional de Segurança Alimentar e Nutricional”. A concepção de segurança alimentar e nutricional cunhada no documento e no evento dava ênfase à autossuficiência alimentar nacional e ao acesso universal aos alimentos, além de sinalizar as diretrizes de uma política nacional de segurança alimentar e a constituição de um Conselho Nacional de Segurança Alimentar (GRISA, 2012) que, de fato, veio a existir em 1993 e, posteriormente, em 2003. ${ }^{12}$ Observa-se aqui uma ampliação das soluções dadas aos problemas da segurança alimentar no país, não apenas focada no combate genérico à fome, mas visando soluções específicas voltadas para isso, tal como a constituição de um Conselho e, posteriormente, a constituição de um sistema integrado de segurança alimentar e nutricional no país.

É importante salientar que as soluções do FSAN se ampliam com o diagnóstico, consolidado na Conferência de 1986, de que

${ }^{12}$ Em 2019 foi anunciada a extinção do Consea, após sua reativação em 2003. 
a fome e a insegurança alimentar [no Brasil] derivavam da incapacidade de acesso aos alimentos, diferentemente da compreensão [...] de que a segurança alimentar dependia estritamente da capacidade de produção agrícola e do abastecimento alimentar de um país. (GRISA, 2012, p. 189).

Dessa forma, a questão ganha um matiz político, envolvendo o tema da desigualdade social e da diversidade cultural no Brasil.

Após a derrota de Lula (PT) nas eleições de 1989, estruturou-se um movimento chamado "Governo Paralelo" que funcionou entre 1990 e 1992 com o objetivo de propor políticas públicas inovadoras. Esse movimento também foi criado como resposta ao período Collor, em que as despesas com alimentação do Governo Federal foram reduzidas em mais de 25\%. À época foi lançado o documento "Política Nacional de Segurança Alimentar”, organizado por Lula e José Graziano da Silva (CONTI, 2016). Nesse documento, o entrecruzamento com a pauta da aquisição de alimentos da agricultura familiar já se fazia presente. O documento foi apresentado ao governo Collor, que o rejeitou. No entanto, “foi parcialmente assumido pelo governo Itamar Franco - e mais tarde se tornou a base do Programa Fome Zero" (CONTI, 2016, p. 70).

Em 1992, acadêmicos e organizações da sociedade civil se reuniram numa ampla pesquisa sobre a fome no Brasil, publicada na obra Mapa da Fome: subsídios à formulação de segurança alimentar (PELIANO, 1993). Naquele ano, no movimento que demandou o impeachment do então presidente Fernando Collor - os “caras pintadas", comandados pelo "Movimento Ética na Política” - surgiram lideranças e atores que se organizaram em torno da campanha "Ação da Cidadania contra a Fome, a Miséria e pela Vida” (CONTI, 2016). Em 1993, uma rede de pessoas e organizações, sob a liderança de Betinho, lançaram essa ação coletiva para dar visibilidade à questão da fome no país. A campanha estimulou a participação popular e a articulação de diferentes setores da sociedade civil por meio da criação de comitês locais que atuavam arrecadando e doando alimentos, bem como despertando a conscientização para o problema. Após o impeachment de Collor, alguns atores que haviam se organizaram em torno do “Governo Paralelo” criaram o Instituto Cidadania, uma organização não 
governamental (ONG) próxima às redes técnicas do Partido dos Trabalhadores e de representantes da academia e de organizações da sociedade civil que tinha grande influência e coordenação de Lula.

Ainda na década de 1990, durante o governo Itamar Franco, foi colocado em operação o primeiro Conselho de Segurança Alimentar e Nutricional (Consea), que reunia sociedade civil e representantes de instituições governamentais para debater o tema da alimentação no Brasil. Nesse tempo, ocorreram os primeiros debates sobre compras públicas de alimentos da agricultura familiar como política agrícola no âmbito federal, que poderia contribuir com entidades socioassistenciais para fortalecer o combate à fome no país. Esse debate era influenciado pela experiência de gestores e representantes de ONGs sobre o tema.

Com a eleição de Fernando Henrique Cardoso (FHC), os rumos das políticas de segurança alimentar mudaram no Brasil. O novo governo lançou o programa "Comunidade Solidária” e substituiu o Consea pelo Conselho da Comunidade Solidária. O programa conferiu selo de prioridade a 16 políticas públicas em diferentes áreas: mortalidade infantil, alimentação escolar, agricultura familiar etc. Nesse período de desmobilização dos atores articulados no "Ação da Cidadania contra a Fome” e no primeiro Consea, em 1998, foi criado o Fórum Brasileiro de Segurança Alimentar e Nutricional. O Fórum mobilizou encontros nacionais defendendo propostas de FSAN no país, bem como atuou no sentido de divulgar ideias de recriação do Consea.

O Fórum cumpriu um importante papel de articulador de acadêmicos e ativistas em torno do FSAN. Nesse sentido, por meio do Fórum, começou a ser inserida no Brasil uma agenda internacional sobre o tema da segurança alimentar e nutricional que contou com a participação de representantes de organizações da sociedade civil brasileira. Cabe destaque à Cúpula Mundial de Alimentação ocorrida em 1996, em Roma, que "começou a trazer o direito à alimentação como um elemento forte e inovador”, segundo entrevistado. ${ }^{13}$

${ }^{13}$ Entrevista XVIII [17.11.2016]. Entrevistador: Lucas Alves Amaral. Skype, 2016. 1 arquivo .mp3 (112min 44s). 
Já nos anos 2000, atores advindos do universo acadêmico, das interações do Governo Paralelo e do Fórum Brasileiro de Segurança Alimentar e Nutricional reuniram-se no âmbito do Instituto Cidadania para produzir um projeto de segurança alimentar que articulasse a complexidade das experiências vividas na última década a partir do acúmulo das reflexões sobre a fome no Brasil. Em 2001, o "Projeto Fome Zero: uma proposta de Política de Segurança Alimentar para o Brasil” foi lançado.

Para finalizar, defendo que o conjunto das iniciativas em rede com atuação de diversos atores sociais e acadêmicos (Ação da Cidadania Contra a Fome, Fórum Brasileiro de Segurança Alimentar e Nutricional, Consea e Instituto Cidadania), bem como os documentos e diagnósticos das décadas de 1980 e 1990, contribuíram para construir os princípios e ideias que sustentam o referencial interpretativo do FSAN. Assim, defendo que as soluções apresentadas ao problema da segurança alimentar e nutricional no Brasil - colocado como o problema da fome até os anos 2000 - são: i) foco no fortalecimento da segurança alimentar e nutricional por meio de ações emergenciais de combate à fome a partir de uma dimensão assistencial; ii) construção de sistemas de gestão entre União, estados e municípios nas ações, em articulação com o Consea federal e Conseas estaduais. Os temas da ênfase na diversificação alimentar, da valorização da diversidade alimentar regional e do combate a outros problemas alimentares que não só a fome, tal como a obesidade, vieram a se tornar soluções posteriores, já nos anos 2000, principalmente por influência de discussões no Consea e durante a implementação do PAA. Por fim, assim como no FAF, percebo que a luta por criar o PAA se encaixa como estratégia de ação orientada pelo enquadramento do FSAN, ou seja, como "causa” do ativismo institucional na criação do Programa.

\section{A criação do PAA}

Segundo Müller (2007), os movimentos sociais, sobretudo os populares do campo, de um modo geral não visualizaram no PAA uma política interessante no momento de sua criação. As soluções da questão agrária obtidas no acesso à crédito em relação ao Pronaf eram as suas estratégias centrais de interlocução com o governo no primeiro ano do primeiro 
mandato presidencial de Lula. O PAA visava garantir mercado aos agricultores e carregava consigo a bandeira do combate à fome, temas que ainda não faziam parte das soluções gerais demandadas pelos movimentos do campo no Brasil à época da criação do programa. Em sua dissertação, Müller (2007) demonstra, portanto, que os movimentos populares do campo não tiveram papel de destaque na criação do programa, tendo se mobilizado mais na sustentação do PAA e na reivindicação pela ampliação do Programa após 2005, conclusão considerada contraintuitiva por muitos. A autora analisa a rede de burocratas que teria criado o PAA e demonstra em sua análise de redes sociais, como constatei depois, que, em sua maioria, esses sujeitos eram oriundos principalmente do universo acadêmico e da própria gestão pública, já que alguns participaram de políticas locais de compras públicas da agricultura familiar nos anos 1980 e 1990. Ou seja, segundo Müller (2007), a rede principal de burocratas que participou ativamente da criação do PAA não é oriunda de movimentos sociais, o que minha pesquisa de campo confirmou.

Ao me deparar com as conclusões da autora, perguntei-me se o PAA teria sido criado única e exclusivamente por interesse do PT, ou da influência do discurso de posse de Lula que atestava ser prioridade de seu governo o combate à fome. Aos poucos pude constatar que, embora o PT e o Instituto Cidadania (ligado ao partido) foram centrais para unir atores diversos na criação do Projeto Fome Zero, os burocratas que contribuíram ativamente na criação do PAA não eram membros do partido. Pelo contrário, segundo os entrevistados, uma minoria tinha vinculação formal com o partido, embora seja possível afirmar que a maioria possuía afinidades normativas com o programa do governo federal à época, dada sua vinculação com as ideias-chaves dos enquadramentos do FAF e do FSAN que se configuravam como causas da criação do PAA. É possível afirmar que esses sujeitos eram, à época, apoiadores do partido. Perguntei-me, então, quais seriam os atores que teriam ocupado cargos na burocracia do novo governo federal em 2003 contribuindo na criação do programa e como teria se dado sua atuação burocrática no processo de criação do PAA. Interessava-me perceber se nesse processo haveria ou não ocorrido ativismo institucional e, em caso afirmativo, como e por quê (ou seja, orientado por quais causas). Vejamos os achados derivados dessas questões. 
Em primeiro lugar, nos relatos sobre o processo de criação do PAA, o perfil de pessoas que ocupavam cargos-chave na burocracia de instituições centrais no novo governo e que foram citados como responsáveis pela criação do PAA era formado, de fato, tal como constatou Müller (2007), em sua maioria, por acadêmicos e gestores que participaram de programas locais de compras públicas da agricultura familiar nas décadas de 1980 e 1990. Além disso, alguns representantes de organizações da sociedade civil atuantes no Fórum Brasileiro de Segurança Alimentar desempenhavam funções na burocracia federal. O que era comum a todos esses sujeitos, isso sim, era o fato de todos terem atuado no processo de criação do Programa Fome Zero no âmbito do Instituto Cidadania em meados de 2000 e 2001. Assim, em segundo lugar, é possível afirmar que o Instituto Cidadania e o Programa Fome Zero foram o espaço e o programa agregadores de uma rede de atores diversos oriundos de diferentes espectros sociais. Defendo que esta agregação se dá, centralmente, pelo compartilhamento entre esses sujeitos de preocupações comuns relativas a seus vínculos aos enquadramentos do FAF e do FSAN.

Em terceiro lugar, em consonância com a última afirmação, os entrevistados de minha pesquisa que foram atuantes na criação do PAA afirmaram firmemente que os burocratas envolvidos na criação do PAA se orientaram por “preocupações genuínas” com os problemas ou da agricultura familiar no país ou da fome no Brasil, ou ambos os problemas conectados, já que tais questões foram acopladas por meio de uma solução no PAA: as compras públicas da agricultura familiar para destinação de alimentos a entidades socioassistenciais. Isso me colocava diante da noção de compromisso com causas. No entanto, parecia-me que essas causas não eram as causas defendidas pelos movimentos sociais naquele contexto. Os movimentos agrários demandavam crédito continuamente nos últimos anos da década de 1990 e início dos anos 2000, e não a garantia de mercado para agricultores familiares por meio de compras públicas.

Isso o que chamo agora de “preocupações genuínas” derivavam das trajetórias pregressas dos burocratas atuantes na criação do PAA no universo acadêmico, na gestão pública e em áreas técnicas de organizações da sociedade civil. Ou seja, é possível afirmar que tais preocupações, em geral, não se conectavam exclusivamente ou prioritariamente com os movimentos sociais 
agrários ou com a Ação da Cidadania Contra a Fome, movimento ligado ao FSAN. Essas afirmações são elucidadas no trecho de entrevista a seguir.

Eu acho que o que acontece é que as pessoas que vinham trabalhando [na criação do PAA em 2003] eram pessoas que tinham uma vinculação com movimentos muito parcial, mais pelo trabalho como técnicos. Então, por exemplo, o [nome] não era indicado de nenhum movimento, nem no MDA nem aqui, nem o [nome], nem nenhum dos secretários. Então eram técnicos, com experiência acadêmica, que trabalhavam com agricultores familiares e com movimentos sociais. Agora, não eram pessoas que vinham indicadas necessariamente dos movimentos. Era da trajetória da carreira mesmo. [...] E mesmo os burocratas que já trabalhavam lá antes, que vinha do Ministério da Agricultura, do grupo de criação do Pronaf, eram técnicos que em algum momento foram envolvendo um ativismo no trabalho, parcerias com agricultores e movimentos, mas ninguém era indicado por movimentos. Eu vejo por exemplo, [nome] foi uma pessoa que trabalhou desde o início da criação do Pronaf, na área de crédito, e ele saiu agora, nessa leva que saiu do MDA com a extinção do Ministério. O [nome] era servidor do RS também... Claro, sempre teve uma militância, mas veio cedido para cá e trabalhou a vida inteira aqui. Claro que ele tinha um compromisso com a agricultura familiar, foi criando vínculos, com os movimentos, mas ele não era bancado por nenhum movimento e o ativismo dele não foi menor por conta disso. ${ }^{14}$

Com o passar das entrevistas e análise das mesmas, constatei que os relatos sobre os eventos que antecederam a criação do PAA remontavam a um dos primeiros encontros do Consea, Conselho reativado no início do primeiro mandato de Lula, que iniciou seu governo com um discurso de posse que colocava o combate à fome entre suas prioridades. Em resumo, o

${ }^{14}$ Entrevista XI [18.08.2016]. Entrevistador: Lucas Alves Amaral. Brasília, 2016. 1 arquivo .$m p 3$ (63min 50s). 
documento “Diretrizes de Segurança Alimentar ao Plano Safra 2003/2004”, foi apresentado pelo conselheiro Plínio de Arruda Sampaio, que teria recebido apoio técnico ${ }^{15}$ de Guilherme Delgado, do Instituto de Pesquisa Econômica Aplicada (Ipea) e acadêmico especializado nas temáticas agrárias e políticas sociais. O documento objetivamente previa recursos do Plano Safra (plano orçamentário, criado em 2003, voltado às safras da produção agrícola nacional) para compras públicas da agricultura familiar que destinassem os produtos comprados ao combate à fome. Esse evento é contado como uma espécie de "mito de criação" do Programa de Aquisição de Alimentos por vários entrevistados.

Ao que parece, ainda, a fala do conselheiro teria incomodado gestores e ministros empossados no governo que representavam interesses conflitantes com a proposta. Esse incômodo já apontava para algumas resistências que o PAA enfrentaria para vir a existir formalmente. As resistências aqui já apontam para a natureza contenciosa em que o ativismo institucional mobiliza suas causas.

Na primeira reunião [...] do Consea, que foi aberta pelo Lula e com presença de Ministros, os diversos de todos os Ministérios que faziam parte do Consea, um conselheiro, Plínio de Arruda Sampaio, pediu a palavra e colocou a seguinte questão: "nós temos um desafio, porque se o Fome Zero vai possibilitar o acesso aos alimentos por parte de um contingente maior, visto que muitas pessoas se alimentam precariamente, é preciso que a gente também identifique quem vai produzir esses alimentos. Não deveriam ser os mesmos produtores que hoje já estão consolidados. Deve-se construir uma proposta voltada para a agricultura familiar, inclusive agricultores mais familiares, que eles próprios também estão vulneráveis à fome, deve-se abrir este mercado para eles”. Então ele propôs um plano de safra para a agricultura familiar, até hoje se chama assim, no qual nós temos o nascedouro do PAA, porque junto com o fortalecimento do Pronaf cria-se então a ideia de um programa de compras institucionais,

${ }^{15}$ Apoio orientado pelos enquadramentos do FAF e do FSAN que pode, inclusive, ser entendido como uma prática ativista em prol desses enquadramentos. 
justamente pensando, de saída, em abastecer instituições, organizações sociais que atendiam populações carentes, esse tipo de coisa, com produção da agricultura familiar. ${ }^{16}$

É justamente após este momento “iniciático”, relatado no trecho anterior, que os relatos sobre a criação do PAA passam a apontar para o que considero práticas de ativismo institucional de burocratas.

José Graziano da Silva - referência acadêmica em estudos sobre as temáticas da agricultura familiar, bem como da segurança alimentar no Brasil - foi um participante ativo na produção do Programa Fome Zero e assumiu o Ministério Extraordinário da Segurança Alimentar (Mesa) no início do governo Lula em 2003. Como foi visto, o pesquisador havia liderado com Lula a construção do documento "Política Nacional de Segurança Alimentar” durante o Governo Paralelo. Esse documento serviu como mecanismo de pressão aos governos Collor e Itamar Franco.

Como ministro do Mesa, Graziano da Silva solicitou o estudo de estratégias para a reversão de recursos do Programa Comunidade Solidária, coordenado por Ruth Cardoso nos governos de Fernando Henrique Cardoso, para o projeto de compras da agricultura familiar (a semente do PAA) que estava em construção. Diante do desafio de criar o Programa era necessário reestruturar o Comunidade Solidária, orientando seus recursos.

No comecinho do governo já recebeu a encomenda de pensar em um programa de compras. O Graziano, eu me lembro bem deste momento, foi bem marcante para mim, que foi quando o Graziano liga para o Valter Bianchini e fala: "nós vamos converter o recurso que era da Comunidade Solidária”, que era do FHC, que a esposa dele coordenava a área social, a Ruth Cardoso, e tinha um orçamento lá e tal e vamos converter isso em compras na agricultura familiar". A gente passou 6 meses, de janeiro a julho, discutindo como fazer isso, porque a 8.666 [Lei de Licitações] não permite selecionar. "Como vamos fazer isso por meio de licitação?” Então era esse marco legal que impedia.

${ }^{16}$ Entrevista XVIII [17.11.2016]. Entrevistador: Lucas Alves Amaral. Skype, 2016. 1 arquivo .mp3 (112min 44s). 
Então ali neste primeiro momento a gente recebeu esta encomenda. Então é esta a trajetória [...] Então, apesar das diretrizes [propostas no Consea] serem consideradas o documento inaugural, houve uma autonomia grande do ministro [José Graziano da Silva] no sentido de propor o PAA, completamente dentro das diretrizes, mas com uma abrangência e uma autonomia maior em relação à política agrícola, até porque os recursos na época eram integralmente recursos manejados pelo Mesa. ${ }^{17}$

Além da atitude proativa de Graziano da Silva em relação ao orçamento, após a proposta discutida no Consea exposta anteriormente o ministro teria solicitado a criação de um Grupo de Trabalho (GT) interministerial formado por MDA, Mesa, Conab, Ipea e Consea. A iniciativa e a produção desse GT apontam para como operou o ativismo institucional desempenhado naquele contexto: por meio da reunião de uma equipe interministerial alinhada pelas soluções-chave dos enquadramentos do FAF e do FSAN, e tendo uma ação estratégica derivada desses enquadramentos interpretativos a ser realizada a criação do PAA. Esse processo se deu em meio a uma grande preocupação com a celeridade de construção de uma oportunidade a partir das propostas de Diretrizes de Segurança Alimentar ao Plano Safra 2003/2004.

O processo em pauta não pode ser descrito como a simples constituição de mais um GT interministerial, pois esteve ancorado na junção de soluções-chave dos referenciais interpretativos inovadores no interior do Estado brasileiro até os anos 2000, o FAF e o FSAN. Essa inovação fica expressa na fala a seguir, quando o entrevistado compara um modelo “antigo” de atuação burocrática a um modelo “novo”, ensejado pelos novos burocratas. Nomeia-se esse grupo de burocratas como "a equipe de governo do Lula com seu time”.

Não era a galera que estava aqui [antes]. A galera que estava aqui resistente, no modelo anterior, modelo antigo. A gente teve que ir rompendo com isso. Quem trouxe isso

${ }^{17}$ Entrevista V. [10.11.2015]. Entrevistador: Lucas Alves Amaral. Brasília, 2015. 1 arquivo .mp3 (64min 10s). 
foi a equipe de governo do Lula com seu time, suas forças políticas que vieram para dentro do Estado. ${ }^{18}$

A atuação burocrática no GT demandou o que Emirbayer e Mische (1998) chamaram de ação reprodutiva: a própria criação do GT interministerial. Ou seja, a utilização dos dispositivos normativos e institucionais disponíveis no contexto. Além disso, essa atuação ocorreu por meio de agências projetivas, no sentido de produção de esforços para a transformação da ordem vigente por meio do estudo e da utilização do processo legislativo na criação de um novo marco institucional futuro.

Segundo Müller (2007), a equipe ligada à Secretaria Executiva do Ministério Extraordinário formulou o primeiro texto de redação do PAA com a intenção estratégica de "esperar” pela possibilidade de sua instituição no Legislativo brasileiro. Assim, observa-se que burocratas vinculados ao Mesa, por meio da liderança de Graziano da Silva, desempenharam papel central na atuação do GT de criação do PAA:

A equipe mais diretamente ligada à Secretaria Executiva do Mesa formulou um texto de redação simples, e ficou aguardando até que uma lei de assunto semelhante fosse enviada à Câmara de Deputados, para inserir os pontos sobre o PAA. Foram cerca de três meses entre a redação do texto e sua inserção em uma Lei. (MÜLLER, 2007, p. 89).

Foi necessário um amplo trabalho de estruturação de alternativas legais e viáveis para a caracterização legal de um programa de compras públicas da agricultura familiar e doação para entidades da rede de assistência social brasileira. Nas palavras de alguns dos entrevistados, foi necessário “cavar” uma "brecha” em uma lei de outro tema para a institucionalização do PAA. Os termos sugerem tanto entraves institucionais para a possibilidade de uma lei que viabilizasse o programa quanto a necessidade de envolvimento engajado dos burocratas a ponto de fazê-los romper com os

${ }^{18}$ Entrevista V. [10.11.2015]. Entrevistador: Lucas Alves Amaral. Brasília, 2015. 1 arquivo .mp3 (64min 10s). 
protocolos básicos que se esperam de sua função e insistir em agências situadas projetivas, deliberativas e estratégicas num contexto contencioso.

Para o Programa de Aquisição de Alimentos vir a existir foi necessário, portanto, criar um mecanismo legal de compras públicas que não precisasse atravessar os processos rígidos previstos na Lei de Licitações. Esse foi o maior entrave jurídico à criação da política. O principal debate sobre tal entrave atravessava os limites do escopo do próprio poder Executivo. Seria necessário recorrer ao Legislativo para a criação de uma lei. Acreditava-se, no entanto, que o Congresso Nacional não aprovaria uma regra que propusesse exceção à Lei de Licitações para compras públicas de uma minoria social como os agricultores familiares. Primeiro, a bancada ruralista poderia ver na exceção um conflito de interesses para os grandes produtores agropecuários brasileiros. Segundo, o lobby das merendas possuía forte influência junto aos deputados (MÜLLER, 2007). Além disso, discursos da oposição e da grande mídia sugeriam uma possível inabilidade do governo para a execução eficaz de políticas públicas.

Os membros do GT, no entanto, enxergaram uma "janela de oportunidade” a ser aproveitada no contexto de início do governo Lula. Alguns fatores apontavam para isso: o plano de governo estava alinhado com o FAF e o FSAN, oriundos de interações históricas complexas e fonte de apoios diversos; os ocupantes de cargos na burocracia estatal do arranjo político-institucional recém-criado haviam participado da criação do Programa Fome Zero, tendo consigo metas bem claras para a criação do PAA; a existência de um canal de mobilização e aproximação de organizações da sociedade civil do governo (o Consea) que criava mecanismos de pressão externa no Legislativo; por fim, a possibilidade de inclusão do futuro PAA no orçamento federal por meio do Plano Safra, uma oportunidade orçamentária vultuosa e concreta. Dito isso, fazia-se necessária uma estratégia - que pode ser identificada no relato a seguir, de um interlocutor de Grisa (2012) que participou desse processo -, indicada pelas agências de "correr contra o tempo", de "articulação” no Legislativo e de construção de "legitimidade” nas práticas ensejadas pelo GT.

E aí nós tivemos que correr porque o Plano Safra tem um calendário, então em um mês este Grupo de Trabalho que foi constituído - Ipea, Conab, MDA e Mesa - nós fizemos uma proposta - as Diretrizes ao Plano Safra - que já entrou 
na segunda reunião do Consea em fevereiro. Ao entrar no Consea, foi um pouco surpresa, não estava esperando que viesse uma coisa articulada, com a legitimidade, que já vinha apoiada pelas áreas técnicas destes três Ministérios. Aí eles pediram mais um mês. Na reunião seguinte em março, ele foi aprovado como diretrizes ao Presidente da República. (GRISA, 2012, p. 218).

Diante dos entraves apresentados, os burocratas do GT se muniram, também, de agências discursivas para negociar e se articular às redes de parlamentares da bancada do PT no Legislativo com o intuito de estudar e refletir alternativas para a criação de uma lei. Nas palavras de Müller (2007, p. 89) iniciou-se "uma intensa negociação entre os deputados da base, a Secretaria Executiva do Mesa, a Casa Civil e os Ministérios”. No entanto, além do impedimento legislativo de tramitação de uma lei que previsse exceções à Lei de Licitações, havia a variável “tempo" como um desafio à criação do PAA, pois existia uma ordem central do núcleo político do governo de que tais ações fossem rápidas. Como resultado desse processo, o GT durou apenas de janeiro a julho de 2003, considerando-se o tempo de sua mobilização e atuação, tendo obtido êxito ao contribuir com a criação e inserção do artigo 19 (a criação do PAA) ${ }^{19}$ na Lei no 10.696 de 2003 que "dispõe sobre a repactuação e o alongamento de dívidas oriundas de operações de crédito rural, e dá outras providências”.

Porque isso foi uma coisa que eu até não sabia, que eu aprendi com a prática, que era uma coisa que se fazia muito. Você queria passar determinada proposta que no fundo mereceria ser uma lei, mas para agilizar no Congresso Nacional você enxertava ela em outra lei e ela passava ali dentro. ${ }^{20}$

${ }^{19}$ Art. 19. Fica instituído o Programa de Aquisição de Alimentos com a finalidade de incentivar a agricultura familiar, compreendendo ações vinculadas à distribuição de produtos agropecuários para pessoas em situação de insegurança alimentar e à formação de estoques estratégicos (Regulamento).

${ }^{20}$ Entrevista XVIII [17.11.2016]. Entrevistador: Lucas Alves Amaral. Skype, 2016. 1 arquivo .mp3 (112min 44s). 
Basicamente, o objetivo da lei citada é organizar o Programa Especial de Crédito para a Reforma Agrária (Procera). Mas em seu artigo 19 se deu, "entre outras providências”, a criação do Programa de Aquisição de Alimentos. Tal artigo originou um marco legal importante para as soluções-chave do FAF e do FSAN nas políticas públicas brasileiras. Este pequeno e frágil artigo 19 é o ápice de um processo de inserção, na estrutura institucional do Estado brasileiro, de soluções dadas aos problemas fundamentais do FAF e do FSAN; é fruto de compromissos com as causas derivadas desses enquadramentos interpretativos. Assim, o vínculo maior dessas causas orientadoras de ativismo institucional não se deu somente com movimentos sociais, mas sobretudo com ideias produzidas interativamente por múltiplos atores, dentre os quais se incluem os movimentos sociais.

\section{Considerações finais}

Do ponto de vista da proposta teórica deste capítulo, pode-se concluir que a articulação entre ativismo institucional e enquadramentos interpretativos nos mostra a complexidade das causas que mobilizam o ativismo institucional de burocratas na implementação de políticas públicas, apontando para a história e a contribuição de múltiplos atores a essas causas. É justamente por isso que é possível afirmar, a partir deste estudo de caso, que o conceito de enquadramentos interpretativos é útil na identificação dos processos históricos dos quais advêm causas coletivas defendidas por burocratas que não são membros de movimentos sociais.

Nesta análise do ativismo institucional na criação do Programa de Aquisição de Alimentos nota-se explicitamente que, mesmo que movimentos sociais possam ter influência na produção histórica das causas que produzem ativismo institucional, nem sempre ativistas institucionais são ou foram membros diretos desses movimentos sociais. Atores oriundos da gestão pública, do universo acadêmico e de organizações da sociedade civil em geral podem praticar ativismo institucional quando ocupam cargos burocráticos, orientados pela identificação de problemas, produção de soluções e engajamento com práticas - processos oriundos dos enquadramentos interpretativos. Suas preocupações são coletivas e podem ser consoante às preocupações 
de movimentos populares, mas seus vínculos podem ser vistos como vínculos a enquadramentos interpretativos, que partem de problemas, soluções e orientações para a ação estratégica em contextos contenciosos.

No que tange ao estudo de caso aqui descrito, observou-se que o ativismo institucional na criação do PAA se deu por meio da estruturação de um Grupo de Trabalho interministerial criado depois de debates no Consea e a partir do fomento de José Graziano da Silva, do Mesa. Por meio do GT uma série de ações com vistas à construção de um marco legal do PAA foi empreendida. “Cavar” um "enxerto” numa lei de outro tema foi uma saída possível diante dos entraves do contexto à operacionalização prática das soluções-chave do FAF e FSAN por parte dos burocratas orientados por tais enquadramentos.

De acordo com a tipificação de ativismos institucionais empreendida por Brandão e Vilaça (2017, p. 12) pode-se classificar o ativismo dos burocratas do GT de criação do PAA como um "ativismo disruptivo de tipo estruturante”: "um esforço de engenharia baseado em objetivos estruturantes para promover grandes mudanças no desenho de políticas públicas”. A agência é “estruturante” pois os objetivos dos burocratas do GT foi promover uma mudança significativa no quadro da legislação brasileira, introduzindo uma alternativa à Lei de Licitações, bem como promover a inclusão de soluções centrais aos enquadramentos do FAF e do FSAN que ainda não encontravam eco em políticas públicas federais no Brasil. Além disso, o ativismo do GT pode ser entendido como “disruptivo” porque o esforço empregado pelos burocratas atuantes neste GT envolveu justamente criar e introduzir, por meio do PAA, um novo modelo de política pública que pode ser considerada paradigmática, por unir soluções importantes para o fortalecimento da agricultura familiar e da segurança alimentar e nutricional numa mesma política. Assim, as soluções-chave do FAF e do FSAN que não tinham espaço no âmbito do Estado passam a operar de modo especial no PAA.

Por questões de espaço, não analisei aqui dois processos interessantes no estudo realizado sobre a criação e implementação inicial do PAA. Primeiramente, identifiquei o privilegiamento do FAF em relação ao FSAN na orientação das agências burocráticas nos primeiros anos de implementação do programa. Esse processo partia do entendimento que a finalidade central do programa seria, além da reserva de mercado, contribuir com o 
associativismo dos agricultores familiares - solução que foi agenciada fortemente por burocratas situados no Mesa e na Conab, que eram as estruturas centrais de gestão e operação do PAA no seu desenho inicial. No entanto, esse processo mudou radicalmente a partir da extinção do Mesa em 2004, derivada, dentre outras razões, de uma crise no governo, e a consequente criação do Ministério do Desenvolvimento Social e Combate à Fome (MDS) e sua ascendência à coordenação do Programa. A criação do MDS envolveu a chegada de uma nova comunidade de atores burocráticos no âmbito da implementação do PAA, que, aos poucos, passou a privilegiar as soluções-chave do FSAN em detrimento das soluções-chave do FAF, mudando a lógica de implementação do PAA em relação ao seu projeto original. Assim, embora o PAA seja, a princípio, uma saída prática para os problemas e soluções tanto do FAF quanto do FSAN, o modo de operá-lo é fonte de controvérsias entre os burocratas implementadores do programa ao longo de sua trajetória.

Por fim, esta análise mostrou como os enquadramentos do FAF e do FSAN foram sendo articulados, ao longo das décadas anteriores à eleição de Lula em 2003, por uma rede sobreposta de defensores localizada em diversas instituições estatais e não estatais. Sustento a tese de que o PAA pode ser entendido como o resultado de um trabalho de acoplamento desses dois enquadramentos distintos. ${ }^{21}$ Esse acoplamento, no entanto, é instável em sua implementação. De todo modo, os burocratas que produziram ativismo institucional contribuíram não só para a criação institucional do PAA, mas para as colagens ideacionais do programa que já vinham sendo tecidas e são formalizadas no Programa Fome Zero. Os processos aqui indicados são melhor analisados em Amaral (2018) e serão objeto de futuras reflexões.

${ }^{21} \mathrm{O}$ acoplamento é um mecanismo de junção de duas ou mais ideias e guias de ação, processo que também é fortemente influenciado pela interação social em contextos específicos (GOFFMAN, 2012). O processo de acoplamento introduz uma nova "laminação" de significados nos enquadramentos anteriores, que não deixam de existir, mas passam a compor novas possibilidades provocadas pela junção. Um terceiro enquadramento misto surge dos frames anteriores. O processo de acoplamento é dinâmico e não se esgota em um evento ou não intenção de sujeitos isolados. 


\section{Referências}

ABERS, Rebecca Neaera. Bureaucratic activism: pursuing environmentalism inside the Brazilian state. Latin American Politics and Society, v. 66, n. 2, p. 22-44, may 2019.

ABERS, Rebecca Neaera. Ação criativa em ecologias complexas: a construção da autoridade prática de políticas associativas. 2018 (no prelo).

ABERS, Rebecca Neaera. Ativismo na burocracia? O médio escalão do Programa Bolsa Verde. In: CAVALCANTE, Pedro; LOTTA, Gabriela (org.). Burocracia de médio escalão: perfil, trajetória e atuação. Brasília: ENAP, 2015. p. 143-176.

ABERS, Rebecca Neaera; SERAFIM, Lizandra; TATAGIBA, Luciana. Repertórios de interação Estado-sociedade em um Estado heterogêneo: a experiência na era Lula. Dados - Revista de Ciências Sociais, Rio de Janeiro, v. 57, n. 2, p. 325-57, 2014.

ABERS, Rebecca Neaera; TATAGIBA, Luciana. Institutional Activism: Mobilizing for Women's Health from Inside the Brazilian Bureaucracy. In: ROSSI, Federico M.; von BÜLOW, Marisa (org.). Social Movement Dynamics: New Perspectives on Theory and Research from Latin America. London: Ashgate, 2015, p. 73-101.

AMARAL, Lucas Alves. Entre ativismos, enquadramentos e controvérsias: as ideias e as agências de burocratas no Programa de Aquisição de Alimentos (PAA). 2018. 212 f., il. Tese (Doutorado em Ciência Política) - Instituto de Ciência Política, Universidade de Brasília, Brasília, 2018. BENFORD, Robert; SNOW, David. A framing process and social movements: an overview and assessment. Annual Review of Sociology, n. 26, p. 611-639, 2000. 
BRANDÃO, Igor Dias Marques Ribas; VILAÇA, Luiz Henrique Doria. Ativismo burocrático na construção de Belo Monte e na inclusão socioprodutiva de catadores de materiais recicláveis. Artigo. In: ENCONTRO INTERNACIONAL DE PARTICIPAÇÃO, DEMOCRACIA E POLÍTICAS PÚBLICAS, 3., 30 mai. a 2 jun., Universidade Federal do Espírito Santo, Vitória, 2017.

BRASIL. Presidência da República. Conselho Nacional de Segurança Alimentar e Nutricional. Diretrizes de segurança alimentar e do desenvolvimento agrário para o Plano Safra 2003-2004 (Subsídios técnicos do CONSEA). Brasília, 2003.

BRASIL. Presidência da República. Lei n. 8.666, de 21 de junho de 1993. Regulamenta o art. 37, inciso XXI, da Constituição Federal, institui normas para licitações e contratos da Administração Pública e dá outras providências. Diário Oficial da União, p. 8269, 22 jun. 1993. Disponível em: http:// legislacao.planalto.gov.br/legisla/legislacao.nsf/Viw_Identificacao/lei\%20 8.666-1993?OpenDocument. Acesso em: 3 nov. 2017.

COMPANHIA NACIONAL DE ABASTECIMENTO. Programa de Aquisição de Alimentos - PAA: Legislação básica. Brasília: 2013.

CONTI, Irio Luiz. Organizações sociais e políticas públicas: inserção da Fetraf-Sul nas políticas públicas de segurança alimentar e nutricional. 2016. 329 f., il. Tese (Doutorado em Desenvolvimento Rural) - Faculdade de Ciências Econômicas, Universidade Federal do Rio Grande do Sul, Porto Alegre, 2016.

D’ARAÚJO, Maria Celina (org.). Governo Lula: contornos sociais e políticos da elite no poder. Rio de Janeiro: Centro de Pesquisa e Documentação de História Contemporânea do Brasil, 2007.

DELGADO, Guilherme. Pesquisa de avaliação da concepção e implementação do Programa de Aquisição de Alimentos (PAA): relatório de avaliação do PAA. Projeto BRA 03/034. Brasília: Companhia Nacional de Abastecimento/ Programa das Nações Unidas para o Desenvolvimento, 2013. 
DELGADO, Guilherme. O papel do rural no desenvolvimento nacional: da modernização conservadora dos anos 1970 ao Governo Lula. In: DELGADO, Guilherme. Brasil rural em debate: coletânea de artigos. Brasília: Conselho Nacional de Desenvolvimento Rural Sustentável/ Núcleo de Educação à Distância, 2010. p. 28-78.

EMIRBAYER, Mustafa; MISCHE, Ann. What is Agency? The American journal of sociology, Chicago, v. 103, n. 4, p. 962-1023, jan. 1998.

GOFFMAN, Erving. Frame analysis. New York: Harper, 1974.

GOFFMAN, Erving. Os quadros da experiência social: uma perspectiva de análise. Petrópolis: Editora Vozes, 2012.

GRISA, Catia. Políticas públicas para a agricultura familiar no Brasil: produção e institucionalização das ideias, 2012. 280 f. Tese (Doutorado em Ciências Sociais) - Programa de Pós-Graduação em Desenvolvimento, Agricultura e Sociedade, Universidade Federal Rural do Rio de Janeiro, Rio de Janeiro, 2012.

GRISA, Catia; KATO, Karina Y. Martins; FLEXOR, Georges Gerard. Capacidades estatais para o desenvolvimento rural no Brasil: análise das políticas públicas para a agricultura familiar. Sociedade e cultura, Goiânia, v. 20, n. 1, p. 13-38, 2017.

GRISA, Catia; SCHNEIDER, Sergio. Três gerações de políticas públicas para a agricultura familiar e formas de interação entre sociedade e Estado no Brasil. Revista de Economia e Sociologia Rural, Brasília, v. 52, supl. 1, p. 125-146, 2015.

GRISA, Catia; TRINCHES, Rozane Maria. Entre mudanças e conservadorismos: uma análise dos programas de aquisição de alimentos (PAA e PNAE) a partir da retórica da intransigência. Revista Nera, Presidente Prudente, ano 18, n. 26, edição especial, p. 10-27, 2015.

HAY, Colin. Constructivist Institutionalism. In: BINDER, Sarah A.; RHODES, Roderick. A. W; ROCKMAN, Bert A. The Oxford Handbook of Political Institutions. Oxford: Oxford University Press, 2008. 
INSTITUTO CIDADANIA. Projeto Fome Zero: uma proposta de política de segurança alimentar para o Brasil. São Paulo: Instituto Cidadania, 2001. LICHTERMAN, P. Beyond the Seesaw Model: public commitment in a culture of self-fulfillment. Sociological Theory, v. 13, n. 3, p. 275-300, 1995. MENDONÇA, Ricardo Fabrino; SIMÕES, Paula Guimarães. Enquadramento: diferentes operacionalizações analíticas de um conceito. Revista Brasileira de Ciências Sociais, v. 27, n. 79, p. 187-235, jun. 2012.

MINAYO, C. S. Raízes da fome. Petrópolis, RJ: Editora Vozes, 1985.

MÜLLER, Ana Luiza. A construção das políticas públicas para a agricultura familiar no Brasil: o caso do Programa de Aquisição de Alimentos. 2007. 128 f., il. Dissertação (Mestrado em Desenvolvimento Rural) - Programa de Pós-Graduação em Desenvolvimento Rural, Universidade Federal do Rio Grande do Sul, Porto Alegre, 2007.

NUNES, Jordão Horta. Interacionismo simbólico e movimentos sociais: enquadrando a intervenção. Revista Sociedade e Estado, Brasília, v. 28, n. 2, p. 257-277, mai./ago. 2013.

OLIVEIRA, Jonatan Alexandre. Políticas públicas para agricultura familiar: o caso do Programa de Aquisição de Alimentos (PAA) no estado de São Paulo, Brasil. 2015. 103 f., il.Dissertação (Mestrado em Geografia) - Instituto de Geociências Exatas, Universidade Estadual de São Paulo, São Paulo, 2015.

PELIANO, Ana Maria T. M. (Coord.). O mapa da fome: subsídios à formulação de uma política de segurança alimentar. Brasília: Ipea, 1993. (Documento de política, n. 14).

PICOLOTTO, Everton L. Os atores da construção da categoria Agricultura Familiar no Brasil. Revista de Economia e Sociologia Rural, Piracicaba, v. 52, supl. 1, p. 63-84, 2014. 
PIRES, Roberto; GOMIDE, Alexandre. Capacidades estatais e democracia: a abordagem dos arranjos institucionais para análise de políticas públicas. In: PIRES, Roberto; GOMIDE, Alexandre. Capacidades estatais e democracia: arranjos institucionais de políticas públicas. Texto para Discussão. Brasília: Ipea, 2014. p. 15-28.

PORTO, Sílvio Isoppo. Programa de Aquisição de Alimentos (PAA): política pública de fortalecimento da agricultura familiar e da agroecologia no Brasil. 2014. 132 f., il. Dissertação (Mestrado em Agroecologia) - Programa Oficial de Postgrado em Agroecología, Universidad Internacional de Andalucía, Espanha, 2014.

RECH, Carla Michele; SILVA, Marcelo Kunrath. Ativismo institucional como categoria analítica para o estudo das práticas políticas dos movimentos sociais no Brasil. SEMINÁRIO NACIONAL DE SOCIOLOGIA DA UFS, 1., 2016, Aracaju. Anais [...] Aracaju: Universidade Federal do Sergipe, 2016. SANTORO, Wayne A.; McGUIRE, Gail M. Social movement insiders: the impact of institutional activists on affirmative action and comparable worth policies. Social Problems, v. 44, n. 4, p. 503-519, nov. 1997.

SCHMIDT, Vivien A. Discursive institutionalism: the explanatory power of ideas and discourse. Political Science, Palo Alto, v. 11, p. 303-326, jun. 2008. SUREL, Yves. The role of cognitive and normative frames in policy-making. Journal of European Public Policy, v. 7, n. 4, p. 495-512, 2000. 


\section{Capítulo 2}

\section{Efeito ricochete: ${ }^{1}$ \\ trajetórias \\ técnico-políticas e \\ a criação de novos modelos de políticas públicas}

Igor Brandão

A literatura sobre as relações entre movimentos sociais e políticas públicas tem destacado três papéis para a sociedade civil em processos de construção institucional. Primeiro, o de democratizar a produção de políticas em um ambiente de governança cada vez mais complexo. Segundo, o de suprir o Estado com capacidades para produzir políticas efetivas. E, terceiro, o de mobilizar atores para pressionar representantes e burocratas em favor de pautas defendidas por organizações da sociedade (ABERS; KECK, 2017; ABERS et al., 2018; CARLOS et al., 2017). Recentemente, autoras têm investigado também como o ativismo e as trajetórias de atores

1 Usei o termo ping-pong para me referir ao mesmo efeito em trabalhos anteriores (cf. BRANDÃO, 2018). 
vinculados a movimentos sociais afetam a mudança de políticas (ABERS, 2018; GUTIERRES, 2018; OLIVEIRA, 2016; RICH, 2019).

No entanto, pouco se sabe sobre como trajetórias individuais se transformam em elementos que incidem nas políticas públicas. Este capítulo busca preencher tal lacuna por meio do estudo de caso de uma mudança de política ocorrida no contexto do processo de construção do regime brasileiro de políticas de resíduos (BRANDÃO; GUTIÉRREZ, 2016, 2018). A mudança contribuiu para o desenho da moldura do regime, constituído, entre outros arranjos e institucionalidades, pelas Leis Federais 11.445/2007 e 12.305/2010, relativas às Políticas Nacionais de Saneamento Básico (PNSB) e Resíduos Sólidos (PNRS).

Inspirado por estudos distintos sobre os efeitos políticos da circulação de pessoas em espaços de poder (SCHNEIDER, 1994; GUTIÉRREZ, 2010; BIANCHI; ALIAGA, 2012; ABERS; KECK, 2013; SOUZA, 2016; PORTO DE OLIVEIRA, 2017), entendo o termo “trajetórias técnico-políticas” como os caminhos profissionais trilhados por especialistas de um setor de política ao longo de suas vidas. E, seguindo Abers na introdução deste livro, interpreto o conceito de ativismo institucional como um tipo de ação criativa capaz de mediar relações e ideias entre atores situados no Estado e na sociedade civil.

O principal argumento do capítulo é que um grupo de especialistas em saneamento ambiental e assistência social se habilitou a mediar o processo de criação de um novo modelo de gestão integrada de resíduos sólidos urbanos (Girsu) no Brasil. Modelos de políticas públicas podem ser compreendidos aqui similarmente ao que Deborah Stone $(1989,2012)$ chamou de "narrativa". ${ }^{2}$ Narrativas dizem porque um problema ocorre, sobre o que ele diz respeito, quem deve ser culpado, e o que pode ser feito para solucioná-lo. Símbolos e números conectados de maneira coerente transformam uma condição em problema sobre o qual alguma ação deve ser realizada. E foi por meio da elaboração de uma narrativa específica sobre o problema da gestão municipal de resíduos no Brasil que aquele grupo de especialistas mediou o processo de criação de um novo modelo Girsu. Dessa maneira, incidiu sobre a mudança de política que resultou na PNSB e na PNRS.

2 Tradução livre de storytelling e framing, entendidos aqui como sinônimos. 
A análise se baseia em pesquisa de campo realizada entre 2014 e 2017 (BRANDÃO, 2018), cuja coleta de dados se deu por meio da participação em 15 eventos e reuniões públicas, da leitura de documentos públicos e privados, e da avaliação qualitativa de 90 entrevistas aprofundadas com dois tipos de interlocutores - pessoas que participaram da construção do regime brasileiro e pessoas que possuíam expertise relacionada ao manejo de resíduos sólidos nos níveis nacional e internacional.

Na seção seguinte, discuto o papel de trajetórias técnico-políticas como elementos fundamentais para a transformação de políticas públicas. Depois, descrevo o processo histórico de criação de um novo modelo Girsu no Brasil, sua experimentação no nível municipal e a constituição de uma comunidade de especialistas em seu suporte. Em seguida, analiso a articulação da coalizão discursiva Lixo e Cidadania e suas ações para transportar aquele modelo para uma escala maior, nacional. Por fim, concluo que a mudança foi construída, em parte, por atores que migraram entre organizações estatais e não estatais em níveis de governo distintos, compartilharam objetivos mais amplos com atores situados fora do Estado e, assim, mediaram a criação do novo modelo.

Argumento ainda que sem essa mediação o modelo provavelmente não teria sido incorporado ao regime brasileiro de políticas de resíduos. Na prática, além de cultivar alianças com catadores e membros de organizações da sociedade civil, especialistas mobilizaram recursos em favor da ação de seus apoiadores externos, criando oportunidades de acesso a círculos estatais de desenho da política.

\section{O efeito ricochete e a mudança de políticas públicas}

A partir de perspectivas analíticas opostas, Pareto e Gramsci analisaram o papel da “circulação de elites” na produção de mudanças políticas mais amplas (BIANCHI; ALIAGA, 2012). Schneider (1994), de outra maneira, argumentou que a circulação interburocrática de uma elite de funcionários públicos entre empresas estatais contribuiu para a mudança da política industrial brasileira na década de 1970. O fluxo de pessoas hábeis entre cargos de alto e médio escalão teria produzido um efeito compensatório 
para a baixa institucionalização da burocracia federal, dotando-a de capacidades para mudar a política econômica brasileira naquele contexto.

Gutiérrez (2010), por sua vez, tratou indiretamente da "circulação de pessoas” ao analisar como especialistas na gestão da água mediaram relações e ideias entre técnicos, partidos e políticos profissionais. Aqueles atores teriam empregado seu conhecimento técnico e suas habilidades políticas para assumir posições organizacionais específicas e dali impulsionado as propostas de reforma que defendiam. Souza (2016) enfatizou, ainda, que a circulação de consultores por conferências nacionais sobre políticas setoriais favoreceu o aprendizado da mediação e resultou na obtenção de "capacidades estatais conversacionais”. Esse processo teria disseminado práticas metodológicas inovadoras para organizar processos participativos no interior do Estado brasileiro. Mais recentemente, Porto de Oliveira (2017) argumentou que a circulação internacional de "paradiplomatas” promoveu a difusão do orçamento participativo ao redor do mundo. Tais estudos revelaram como a circulação de pessoas que carregam ideias e experiências práticas entre espaços de poder pode afetar as políticas públicas.

Mas como trajetórias podem habilitar pessoas a agir como mediadores em processos de mudança de políticas? Atores políticos efetivamente circulam por diversas organizações na sociedade civil, no Estado e no mercado, e em diferentes escalas (doméstica e internacional). Ao longo de suas trajetórias, não somente podem carregar ideias e aprender novas habilidades, mas também se posicionar em diferentes redes de relações. Abers e Keck (2017) argumentam que ideias sobre políticas públicas são concebidas em, pelo menos, três tipos de ambientes: debates entre especialistas e não especialistas, nos quais ideias são defendidas; disputas políticas, nas quais ideias que não são específicas para os especialistas entram em discussão; e experimentos práticos em lugares particulares. Nesses espaços, atores (indivíduos e organizações) desenvolveriam capacidades e conquistariam reconhecimento dentro de uma área de política, o que os habilitaria a influenciar o comportamento de outros atores, ampliando suas redes de relações em apoio a suas ideias. Esse processo seria um tipo de aprendizado construtivo que cria poder, autoridade prática.

Enquanto Abers e Keck (2017) defendem que as trajetórias das pessoas, em última instância, são as fontes da autoridade na prática, argumento que 
trajetórias técnico-políticas habilitam sujeitos a mediar o processo de criação de novos modelos de políticas públicas. A força que tais trajetórias exercem sobre certas políticas, por meio da mediação desempenhada por tais atores, denomino efeito Ricochete. Mais especificamente, o processo de habilitação que o constitui se dá por meio de três mecanismos: i) o aprendizado técnico e político sobre como negociar propostas concretas, criar alternativas contextualizadas e traduzir ideias em soluções práticas; ii) a constituição de uma rede de relações entre atores posicionados em organizações estatais e não estatais, em defesa do modelo; e iii) a mobilização de recursos humanos e materiais entre a sociedade civil e o Estado por meio dessa rede.

A decomposição do efeito Ricochete objetiva complementar o aparato analítico de Abers e Keck (2013; 2017), explicitando como atores constroem poder na prática para transformar políticas. Ao acumularem estoques de recursos ao longo de suas trajetórias, destacadamente competências (técnicas e políticas) e posicionamentos em redes de relações entre a sociedade civil e o Estado, certos atores se habilitam a mobilizar recursos a favor de determinados modelos de políticas e em detrimento de outros.

A literatura sobre mudança de políticas públicas tem demonstrado que a complexidade de problemas públicos por si só não determina como as pessoas se engajam na elaboração de propostas para solucioná-los (PETERS; ZITTOUN, 2016). Na prática, atores posicionados em organizações do Estado e/ou da sociedade civil não somente consideram o que fazer, mas como fazê-lo dentro de um contexto de oportunidades e constrangimentos políticos, materiais e institucionais (BRANDÃO, 2018; BRANDÃO; VIANA, 2018; BRANDÃO; VILAÇA, 2017). É por isso que uma compreensão mais apurada sobre como pessoas se habilitam a lidar estrategicamente com tais elementos é fundamental para a interpretação do processo de mudança de políticas.

Parte dessa literatura tem destacado o papel de mediadores na elaboração de propostas de solução para problemas públicos complexos. Mediadores da mudança de políticas públicas podem ser definidos como "intermediários nas interfaces de vários grupos [com] acesso a informações, ideias e posições” (HECLO, 1978 apud HOWLETT et al., 2017, 
p. 235, tradução nossa). ${ }^{3}$ Enquanto o modelo das coalizões de defesa destaca como o processo de negociação da mudança de política pode resultar em aprendizado - quando mediadores costuram consensos entre coalizões com crenças antagônicas (SABATIER, 1988; INGOLD; VARONE, 2012; JENKINS-SMITH et al., 2014) -, o modelo dos múltiplos fluxos enfatiza como o aprendizado afeta a mudança da política - quando mediadores conectam fluxos políticos a propostas de solução, aproveitando janelas de oportunidade (KINGDON, 1995; ZAHADIADIS, 2014; KNAGGÅRD, 2015). Na prática, tais atores usam suas formações e informações técnicas para mediar conhecimentos e relações de poder entre os protagonistas da mudança da política (GUTIÉRREZ, 2010).

No entanto, quando experimentam propostas para soluções conhecidas na teoria, sujeitos aprendem, elaboram e negociam alternativas em torno das quais se aglutinam coalizões discursivas (HAJER, 1993; FISCHER, 2003, 2009; ANSELL, 2011). Para Hajer (1993, p. 47, tradução nossa) tais coalizões são como "aglomerados de conjuntos de linhas de histórias, de atores que contam tais histórias, e de práticas que se conformam a tais linhas de histórias, organizados em torno de um discurso". ${ }^{4}$ Assim, o processo de mudança de políticas é constituído por disputas discursivas entre coalizões nas quais especialistas e não especialistas participam de jogos de linguagem sobre como circunscrever problemas públicos e a eles “colar” soluções específicas. Tais disputas se estabelecem tanto na definição do que é o problema e de quais são suas soluções apropriadas quanto em sua propagação, em busca de legitimação perante um público mais amplo (ZITTOUN, 2014).

Esse processo discursivo de mudança de políticas públicas, entretanto, é marcado também por experimentações práticas que produzem aprendizado, redes de relações, e cumprem papel importante na construção de uma narrativa sobre a política. É aqui que o debate sobre como trajetórias técnico-políticas incidem na mudança de políticas públicas pode ser

3 “[...] middlemen at the interfaces of various groups [with] access to information, ideas, and positions.” (HECLO, 1978 apud HOWLETT et al., 2017, p. 235).

4 “[...] the ensemble of a set of story lines, the actors that utter these story lines, and the practices that conform to these story lines, all organized around a discourse.” (HAJER, 1993, p. 47). 
abastecido por insights produzidos por estudos que analisaram os efeitos da circulação de atores entre espaços de poder.

\section{A criação de um modelo de política em escala local}

Limpeza urbana (LU) e gestão integrada de resíduos sólidos urbanos (Girsu) são as principais narrativas sobre as políticas de resíduos vigentes historicamente no Brasil. Ambas podem ser entendidas dessa maneira porque consistem em conjuntos de práticas variáveis sob o mesmo rótulo, inclusive comportando significados inconsistentes acerca de quais e como diferentes elementos podem ser incorporados ao manejo de resíduos sólidos urbanos.

Enquanto a narrativa da LU ignora o valor econômico, ambiental e social dos resíduos e se refere ao conjunto de ações pelas quais o "lixo” produzido nas cidades é transportado para depósitos - frequentemente inadequados distantes das regiões centrais, com foco na higiene do ambiente urbano e sem preocupação explícita com a integração dos processos e das pessoas envolvidas (SCHAMBER; SUÁREZ, 2007), a narrativa Girsu se refere a esforços para integrar pessoas, máquinas e a infraestrutura das cidades no manejo das etapas de geração, separação, coleta, triagem, recuperação, tratamento e disposição final dos resíduos (PHILIPPI JR. et al., 2012), reconhecendo o valor dos catadores e dos resíduos (GONÇALVES-DIAS, 2009; MNCR, 2012).

Quando a narrativa Girsu surgiu na Europa e nos Estados Unidos durante a década de 1970, defendia-se a redução da quantidade de resíduos gerada, o fim dos lixões e sua destinação adequada em aterros sanitários (DEMAJOROVIC, 1995). Em um contexto de “modernização ecológica”, governos e organizações da sociedade civil passaram a defendê-la como solução ambientalmente adequada para o problema da produção de resíduos nas cidades (SCHEINBERG, 2003). No entanto, nos anos 1980, a expansão urbana produziu escassez de áreas disponíveis para o funcionamento de aterros, enquanto a mobilização de comunidades vizinhas ${ }^{5}$ bloqueava o uso de áreas com essa destinação (BLUMBERG; GOTTLIEB, 1989;

5 Esses movimentos são conhecidos na literatura como Not In My Backyard - NIMB. 
LUTON, 1996). A narrativa Girsu passou então a promover o abandono dos aterros - cujas capacidades se esgotavam rapidamente - e da incineração, incentivando, por outro lado, métodos de tratamento térmico controlados como forma de aumentar a eficiência e mitigar os riscos de poluição do meio ambiente (KREITH; TCHOBANOGLOUS, 2002).

No Brasil, entretanto, municípios enfrentavam graves dificuldades financeiras para construir e administrar aterros sanitários. Inclusive, aqueles financiados com recursos federais se tornavam lixões em seguida, pela incapacidade de investimento das prefeituras em sua manutenção. Diante desses constrangimentos, alguns municípios encontraram soluções consorciadas para administrá-los. Não obstante, padeciam com a escalada dos custos pagos pelos serviços terceirizados de coleta seletiva, o que limitava as possibilidades de expansão e acelerava o esgotamento dos aterros (JACOBI, 2006; BESEN, 2011).

A narrativa da LU predominou historicamente sobre a da Girsu nos municípios brasileiros. Consequentemente, tanto a administração pública quanto as empresas prestadoras de serviços se especializaram no transporte de resíduos, restringindo suas práticas à coleta e à disposição final em áreas afastadas dos centros urbanos. Na lógica de que quanto maior a quantidade de resíduos transportados e aterrados tanto maiores os rendimentos das firmas prestadoras de serviço, nenhum incentivo era produzido para a redução da geração de resíduos, tampouco para a separação do material reciclável na origem pelos cidadãos. Atribuía-se a catadores em situação de rua parte da responsabilidade pela degradação gerada pelo "lixo" espalhado nas cidades, sem o reconhecimento do valor ambiental, social e econômico de sua atividade produtiva. Da mesma maneira, catadores em situação de lixão eram confundidos com os próprios resíduos com os quais trabalhavam.

Muitos catadores encontram-se em situação de rua, mas apenas parte da população em situação de rua trabalha com a catação de materiais recicláveis (FERRO, 2011; SILVA et al., 2013; SILVA, 2017). E, embora seja uma atividade exercida há séculos (BIRKBECK, 1978), as primeiras organizações brasileiras de catadores surgiram durante a redemocratização do país, entre 1982 e 1990. Naquele período, ativistas católicos e socioambientalistas ligados ao Partido dos Trabalhadores (PT) atuaram na formação das primeiras associações e cooperativas em São Paulo, Porto Alegre 
e Belo Horizonte (DEMAJOROVIC; LIMA, 2013; GRIMBERG, 1994; MAGERA, 2003; LIMA, 2004; SCHIOCHET, 2012).

Em seguida, nas primeiras administrações municipais lideradas pelo PT naquele contexto, atores com distintas formações assumiram posições em burocracias municipais, setores como saneamento e limpeza urbana, meio ambiente e assistência social (CUNHA, 2002; DIAS, 2002; GRIMBERG; BLAUTH, 1998; JACOBI; TEIXEIRA, 1997; MARTINS, 2003). Posicionados ali, expandiram suas redes de relações, negociaram propostas concretas e mobilizaram recursos para construir um modelo alternativo de políticas de resíduos no Brasil. Ao migrarem de organizações da sociedade para organizações estatais e multiplicarem seus vínculos, puderam aprender novos saberes técnicos e políticos, adaptar o modelo Girsu internacional à realidade brasileira e se articular de maneira mais ampla em defesa de uma narrativa mais inclusiva.

A mediação exercida por tais atores permitiu que a inclusão social de catadores por meio da incorporação de associações e cooperativas aos sistemas municipais de manejo de resíduos, assim como a gestão compartilhada (tanto com a sociedade quanto entre municípios), passassem a ser defendidas como soluções melhores para mitigar quatro problemas: a degradação ambiental causada pelos lixões; a exclusão social dos catadores; a incapacidade financeira dos municípios para gerir sistemas próprios; e a falta de participação social nas decisões governamentais no setor de resíduos urbanos. A incorporação de associações e cooperativas de trabalho aos sistemas municipais foi defendida como uma estratégia para a reconstrução de vínculos sociais e o desenvolvimento da consciência política dos catadores, além de promover a diminuição dos custos da terceirização do sistema (JACOBI, 2006).

A implementação do modelo se diversificava no Brasil. Conforme apareciam desafios práticos, novas soluções foram sendo criadas e experimentadas. Variavam a quantidade de catadores vinculada a associações e cooperativas participantes dos programas municipais, as possibilidades de incorporação de catadores autônomos aos programas, os tipos de vínculo existentes entre as representações estatais e as organizações da sociedade civil envolvidas, assim como a maneira pela qual municípios passaram a se associar para gerir a infraestrutura necessária ao tratamento de resíduos.

À medida que as cidades brasileiras começaram a experimentar soluções baseadas nessa narrativa inclusiva, ativistas e técnicos de organizações 
internacionais passaram a contribuir para seu desenvolvimento aqui e em outros países do sul global. Nesse sentido, o Grupo de Trabalho Colaborativo sobre Gerenciamento de Resíduos Sólidos em Países de Renda Média e Baixa (CWG) ${ }^{6}$ conectou especialistas brasileiros a uma rede internacional, ampliando a circulação daquelas pessoas e suas práticas pelo mundo (DIAS, 2009; GUTBERLET, 2008; SCHEINBERG; ANSCHTZ, 2007).

Em suma, aqueles atores defenderam uma versão diferente da narrativa Girsu internacional surgida em meados dos anos 1970, em detrimento da visão associada à LU predominante no Brasil. A combinação criativa de ideias desenvolvidas por organizações internacionais com práticas associadas ao cooperativismo, já aplicadas por ativistas em cidades como São Paulo, Porto Alegre e Belo Horizonte, entre outras, se difundiu para inúmeros municípios no Brasil. Pode-se dizer que os experimentos municipais passaram a se desenvolver pelos esforços de atores que navegaram estrategicamente as fronteiras entre diferentes subsistemas de políticas públicas, ocupando posições tanto em organizações estatais quanto na sociedade civil. Tais atores constituíram uma comunidade de especialistas engajados em difundir essa narrativa inclusiva da política, enquanto na prática aperfeiçoavam-na de acordo com as necessidades de cada município.

\section{Ampliando a escala do modelo alternativo para o nível federal}

Como visto na seção anterior, o período pós-1988 foi marcado pelo experimentalismo municipal de políticas setoriais. Especialistas, religiosos e ativistas se reuniam em distintos fóruns e frentes para discutir propostas e articular atores em torno de uma agenda ampla de implementação de direitos à cidadania instituídos pela Constituição. Sob tal perspectiva, os papéis da sociedade civil, do Estado e do mercado adquiriram centralidade em espaços como o Fórum Nacional pela Reforma Urbana (FNRU), criado em 1987, o Fórum Nacional de Estudos sobre a População de Rua (FNPR), criado em 1993, o Fórum Nacional de Prevenção e

${ }^{6}$ Collaborative Working Group on Solid Waste Management in Low and Middle-Income Countries. 
Erradicação do Trabalho Infantil (FNPETI), criado em 1994, a Frente Nacional pelo Saneamento Ambiental (FNSA), criada em 1997, e o Fórum Nacional Lixo e Cidadania (FNLC), criado em 1998 (SCHERER-WARREN, 2007). Essas instâncias reuniam pessoas cujas trajetórias profissionais se associavam à defesa de causas voltadas à justiça social e à preservação do meio ambiente.

Algumas dessas pessoas, com experiência em administrações municipais do PT, passaram a circular entre as cidades administradas pelo partido e debater o novo modelo Girsu em congressos e seminários de especialistas promovidos por entidades como a Abes e o Instituto Pólis. Quando governou o Distrito Federal entre 1995 e 1998, Cristovam Buarque, por exemplo, nomeou pessoas que haviam passado pelas burocracias de cidades como São Paulo, Santo André e Belo Horizonte. Elas traziam consigo o aprendizado técnico e político adquirido em negociações e debates pelos quais haviam passado, e mais uma vez expandiam suas redes de relações que poderiam mobilizar recursos em suporte da narrativa inclusiva.

Outro passo importante na construção do modelo alternativo ocorreu quando a Superintendência de Limpeza Urbana (SLU-BH) recebeu, após experiência exitosa em Belo Horizonte, o Prêmio Gestão Pública e Cidadania da Fundação Getúlio Vargas (FGV), concedido em parceria com a Escola de Governo John F. Kennedy, de Harvard, em 1996. Naquela ocasião, um dos membros do júri que concedeu o prêmio foi Agop Kayan, então diretor do Fundo das Nações Unidas (Unicef) no Brasil, o mesmo que convidaria Heliana Kátia Campos, diretora da SLU-BH, para liderar uma ação nacional em favor da "erradicação do trabalho infantil com o lixo” no país. Era a vez do modelo Girsu alternativo, baseado naquela narrativa inclusiva, repercutir nacional e internacionalmente.

Depois de visitar lixões em municípios brasileiros, a agora consultora do órgão internacional convidou pessoas vinculadas a organizações da sociedade civil e às prefeituras de Porto Alegre e Belo Horizonte para participar da elaboração de um programa nacional. Essa articulação resultou em uma pesquisa realizada pelo Centro de Estudos em Saneamento Ambiental - Água e Vida, ${ }^{7}$ que estimou a quantidade de crianças

7 O Água e Vida surgiu quando engenheiros sanitaristas que trabalhavam nas gestões do PT em São Paulo e Santo André se desligaram do consórcio do ABC paulista, em 1993. 
trabalhando em lixões no Brasil. O estudo concluiu que o problema derivava da precariedade dos sistemas municipais de manejo dos resíduos.

Pessoas que participaram dos experimentos inclusivos das administrações municipais petistas passaram a ser contratadas pelo Unicef para trabalhar como consultores do projeto. Criou-se então o Fórum Lixo e Cidadania (FNLC) para debater a questão do "trabalho infantil no lixo" e articular ações de atores governamentais e não governamentais em defesa da narrativa inclusiva sobre o modelo Girsu alternativo. Surge daí, em 1998, uma coalizão discursiva de atores heterogêneos patrocinada pelo Unicef. Dessa articulação, promoveu-se uma modificação sutil no discurso criado a partir dos experimentos municipais, enfatizando a barbárie do trabalho infantil nos lixões.

A coalizão Lixo e Cidadania passou a agir em diversas frentes. Primeiro, buscou sensibilizar as burocracias federais sobre a importância de destinar recursos para a implementação de seus objetivos, condicionando o repasse à adesão dos municípios. Em seguida, estimulou a adesão de prefeitos mobilizando-os para realizar planos de gestão integrada inclusivos e, assim, conseguir recursos federais destinados à construção de aterros geridos de maneira consorciada. Terceiro, incentivou o estabelecimento de parcerias entre prefeituras e organizações da sociedade civil com o intuito de prover assessoramento técnico à organização de associações e cooperativas de catadores. Impulsionou, ainda, réplicas estaduais e municipais do FNLC e defendeu o modelo Girsu alternativo via campanha publicitária em meios de comunicação de massa (ABREU, 2007; DIAS, 2009).

Estrategicamente, aqueles atores transportaram para o nível federal uma narrativa criada para um problema municipal. Nesse esforço criativo de adaptá-la a uma escala de ação mais ampla, nacional, a erradicação do trabalho infantil com o lixo dependeria de um esforço nacional para o encerramento de lixões, a construção de aterros sanitários compartilhados por municípios vizinhos e a contratação de organizações de catadores para a prestação de serviços de recuperação dos materiais recicláveis. Debatia-se uma legislação nacional que, por um lado, regulasse a responsabilidade de grandes geradores de resíduos e, por outro, incentivasse os municípios a adquirir recursos para policiar o descarte ambientalmente inadequado de resíduos nas cidades, implantando a coleta seletiva. Em resumo, defendia-se a implementação de sistemas municipais integrados com a participação da sociedade. 
A secretaria executiva do FNLC foi exercida pelo Água e Vida, que deu suporte à coalizão discursiva que sustentava a narrativa inclusiva sobre o modelo Girsu alternativo. Articularam-se ali pessoas vinculadas a entidades governamentais e não governamentais com o objetivo de discutir soluções possíveis e implementar ações coordenadas para os problemas enfrentados no setor de resíduos por estados e municípios. O Unicef patrocinou também a assessoria técnica para projetos pilotos de encerramento de lixões por meio do Programa Lixo e Cidadania, desenhado para que municípios pudessem implementá-lo conforme suas próprias necessidades.

Na prática, consultores visitaram parlamentares e burocratas de alto e médio escalão em órgãos federais envolvidos com a gestão de resíduos, como, por exemplo, o Ministério do Meio Ambiente (MMA), a Secretaria de Desenvolvimento Urbano da Presidência (Sedu-PR), a Caixa Econômica Federa (CEF) e a Fundação Nacional de Saúde (Funasa). O objetivo era torná-los receptivos especialmente à eliminação do trabalho infantil e a uma regulamentação nacional acerca do pós-consumo, bem como convencê-los a destinar recursos da União aos municípios, garantindo a viabilização do Programa Lixo e Cidadania.

A coalizão discursiva Lixo e Cidadania lançou ainda a campanha “Criança no Lixo, Nunca Mais”, promovendo uma exposição de arte a céu aberto produzida com sucatas pelo carnavalesco Joãozinho Trinta, no Rio de Janeiro, e com aparições do ator e comediante Renato Aragão na programação da TV Globo. O nome da campanha fazia alusão ao famoso livro de Dom Paulo Evaristo Arns sobre a tortura promovida pelas forças de segurança do regime militar. Concomitantemente, entidades como a Associação Nacional de Serviços Municipais de Saneamento (Assemae) e a Associação Brasileira de Engenharia Sanitária e Ambiental (Abes) se articularam à FNSA, em defesa da gestão pública do saneamento básico no país e contra a privatização das companhias estaduais de água e esgoto.

Um desdobramento dessa mobilização foi a criação, no início de 1999, ${ }^{8}$ da Secretaria de Qualidade Ambiental nos Assentamentos Humanos (SQA)

8 Informação corroborada por declaração do Ministro do Meio Ambiente à época, Sarney Filho, durante audiência pública na Câmara Federal acerca da PNRS sob relatoria de Emerson Kapaz (2001-2002). 
do Ministério do Meio Ambiente (SQA-MMA), que passou a financiar projetos de capacitação e elaboração de planos de gestão integrada de resíduos sólidos. Outro, foi a organização do I Encontro Nacional de Catadores, Técnicos e Agentes promovido pela Associação de Catadores de Materiais Recicláveis de Belo Horizonte (Asmare) em conjunto com a Federação das Associações de Recicladores do Rio Grande do Sul (Farrgs) e a Cooperativa de Catadores de Materiais Recicláveis de São Paulo (Coopamare), com apoio do Fórum Nacional dos Estudos sobre a População de Rua (FNEPR). Dessa articulação surgiu o Movimento Nacional dos Catadores de Materiais Recicláveis (MNCR) (ABREU et al., 2001; DIAS, 2002).

A coalizão impulsionou também a criação de Fóruns Lixo e Cidadania locais. Trabalhos próximos aos catadores passaram a ser desenvolvidos em estados e municípios, integrando ações de organizações governamentais e não governamentais e promovendo a sensibilização de legisladores locais sobre o tema. O Unicef, entretanto, retirou-se das iniciativas em meados de 2001, sendo seu papel substituído parcialmente pelo GTZ, ${ }^{9}$ com recursos do Fundo Nacional do Meio Ambiente e com o apoio de convênio estabelecido entre o Água e Vida e a SQA-MMA. Elaborou-se, em seguida, um relatório de balanço de suas ações, apontando os avanços conquistados e os passos futuros para consolidar o modelo inclusivo de gestão de resíduos emergente no país (ABREU, 2002).

A efetividade da campanha impulsionada para ampliar a escala do modelo inclusivo para o nível nacional pôde ser constatada em 2002, ainda no governo de Fernando Henrique Cardoso: além dos recursos federais destinados aos municípios para a implementação do Programa Lixo e Cidadania, a profissão "catador de material reciclável” foi reconhecida na Classificação Brasileira de Ocupações (CBO).${ }^{10}$ Pela primeira vez, dados sobre as pessoas que executavam a atividade no país passariam a fazer parte das estatísticas, aumentando a visibilidade do problema e permitindo que

9 O Deutsche Gesellschaft für Technische Zusammenarbeit (GTZ), a Organização Alemã para a Cooperação Técnica, em janeiro de 2011, fundiu-se a duas outras, dando origem ao Deutsche Gesellschaft für Internationale Zusammenarbeit (GIZ).

${ }^{10}$ Portaria ${ }^{\circ} 397 / 2002$. 
políticas pudessem ser elaboradas com parâmetros mais claros. Naquele momento, os atores vinculados à coalizão discursiva Lixo e Cidadania, defensores da narrativa inclusiva que sustentava o modelo Girsu alternativo, esperavam que o governo Lula, recém-eleito, adotasse o programa patrocinado anteriormente pelo Unicef e mais: que fosse expandido para todo o território brasileiro.

\section{A mediação da mudança da política por meio da fronteira entre sociedade e Estado}

A chegada do PT à Presidência da República em 2003 nutriu expectativas não somente nos atores que apoiavam a coalizão discursiva Lixo e Cidadania, mas em todos os atores que atuaram em prol da efetivação de direitos à cidadania inscritos na Constituição de 1988. Duas mudanças organizacionais da administração pública federal marcaram aquele momento. Em primeiro lugar, a criação de novas institucionalidades e a alteração da funcionalidade de outras já existentes. Em segundo, a renovação dos quadros de pessoal, por meio da contratação de profissionais com experiências associadas tanto ao trabalho de organizações de movimentos sociais quanto às gestões lideradas até então pelo PT em estados e municípios (ARAÚJO; LAMEIRÃO, 2009; CUNHA, 2012; CARDOSO JR.; BARBOSA, 2017; LOPEZ et al., 2014; ABERS; SERAFIM; TATAGIBA, 2014; SILVA; OLIVEIRA, 2011).

Apesar do êxito em transportar a narrativa Girsu com ênfase no combate ao trabalho infantil para uma escala nacional, a saída do Unicef da coalizão provocou a necessidade de angariar recursos públicos para manter as ações do Fórum Nacional e do Programa Lixo e Cidadania. Também por isso a expectativa daquela rede de especialistas engajados era a de que o novo governo adotasse o programa oficialmente e o ampliasse. É nesse contexto que atores ligados àquela coalizão discursiva vão ocupar cargos em burocracias federais, contribuindo para a construção de oportunidades para mediar a mudança de política que resultou, entre outras coisas, na promulgação da PNSB e da PNRS. 
Dada a priorização de políticas sociais pelo governo Lula - especialmente o Fome Zero e o Bolsa Família -, aqueles especialistas voltaram a enfatizar a narrativa do modelo Girsu como um meio de promover a inclusão social de catadores nas cidades, em detrimento do destaque discursivo anterior dado à erradicação do trabalho infantil com o lixo. Foi nesse sentido que atores ligados à coalizão Lixo e Cidadania assumiram cargos na burocracia federal e articularam a criação do Comitê Interministerial de Inclusão Social dos Catadores de Lixo (Ciisc) ${ }^{11}$ (PEREIRA; TEIXEIRA, 2011). O comitê surgiu com três funções: implementar o "Projeto Interministerial Lixo e Cidadania: Combate à Fome Associado à Inclusão de Catadores e à Erradicação de Lixões”; articular as políticas setoriais e monitorar os programas voltados à "população catadora de lixo"; e definir mecanismos de monitoramento e avaliação dessas ações integradas nas localidades.

As ações implementadas e articuladas pelo Ciisc se pulverizaram entre o Ministério das Cidades (MCidades), o Ministério do Desenvolvimento Social e Combate à Fome (MDS), o Ministério do Trabalho e Emprego (MTE), o MMA, a Petrobras e o Banco Nacional de Desenvolvimento Econômico e Social (BNDES). Algumas delas, inclusive, passaram a ser executadas em parceria com a Fundação Banco do Brasil (FBB), com a Funasa e com a Caixa. Ao longo do tempo, estabeleceu-se uma dinâmica de cooperação e conflitos entre os atores daquela coalizão discursiva, derivadas dos desafios de coordenação de ações voltadas à construção do modelo Girsu alternativo.

No início de 2004, Patrus Ananias, ex-prefeito de Belo Horizonte (1993-1996), assumiu o comando do MDS. Ele nomeou Heliana Kátia Campos para liderar a Secretaria de Articulação Institucional e Parcerias (Saip) que passou a compartilhar a coordenação do Ciisc com Marcos Montenegro, da Secretaria Nacional de Saneamento Ambiental (SNSA), do MCidades, seu marido, que havia participado de gestões municipais do PT em Santo André, Belo Horizonte e Brasília, além do FNRU e da FNSA. A equipe da Saip contava com Maria de Fátima Abreu e Nina Vélez, enquanto a da SNSA contava com Teia Magalhães e Sônia Dias. Todos eles com trajetórias técnico-políticas constituídas pela migração

${ }^{11}$ Ver Decreto s/n de 11 de setembro de 2003. 
entre organizações do Estado e da sociedade civil nas áreas de saneamento, resíduos e assistência social, com envolvimento tanto com os Fóruns Lixo e Cidadania quanto com os experimentos de implementação do modelo alternativo Girsu em administrações do PT.

Na prática, a escalada do modelo ao nível nacional se consolidou por meio de programas e convênios com organizações da sociedade civil e municípios. As primeiras ações orçamentárias voltadas ao manejo dos resíduos sólidos urbanos e à inclusão de catadores apareceram no Plano Plurianual (PPA) de 2004. Introduziu-se o Programa Resíduos Sólidos Urbanos (PRSU-8007) ${ }^{12}$ ali com ações focadas nas diversas dimensões do modelo defendido pela coalizão discursiva Lixo e Cidadania. ${ }^{13}$ Além da possibilidade de estabelecer convênios diretamente com a União, organizações da sociedade civil puderam financiar o assessoramento técnico a redes de cooperativas de catadores em inúmeros estados do país por meio do Programa Petrobras Fome Zero (SOTO, 2011).

Essa canalização de recursos, principalmente para organizações da sociedade civil, contribuiu para a coordenação de ações entre atores dentro e fora do Estado, em favor da aprovação das leis da PNSB e da PNRS, entre 2007 e 2010. Ambas institucionalizaram a possibilidade de contratação de cooperativas e associações de catadores por municípios, com dispensa de licitação. Diferentemente do modelo fundamentado na narrativa LU, baseado na terceirização de serviços públicos para empresas de coleta e tratamento de resíduos, essa legislação responsabilizaria objetivamente grandes negócios por parte da geração de resíduos, o que anteriormente onerava demasiado os poderes públicos municipais.

As leis da PNSB e da PNRS foram apoiadas tanto por catadores quanto por municípios porque fortaleceriam os primeiros enquanto desoneraria os últimos, ao mesmo tempo em que significaria novos custos para empresários de diversos setores. Por um lado, aquela institucionalidade provocaria a redução da

12 Sigla contida no respectivo PPA.

${ }^{13}$ O Governo Federal introduziu outro programa orçamentário voltado ao setor de resíduos sólidos após a aprovação da PNRS, chamado Programa Resíduos Sólidos (PRS-2067), no PPA 2012-2015. 
quantidade geral de materiais coletada, transportada e disposta por empresas contratadas pelo poder público municipal nas cidades. Por outro, favoreceria cooperativas de catadores como empreendedoras sociais no mercado da reciclagem.

O gráfico 1, a seguir, mostra o volume de recursos transferidos para organizações da sociedade civil ${ }^{14}$ e entes federados entre 2004 e 2015. Quatro informações chamam a atenção: o predomínio de recursos transferidos para unidades subnacionais, aproximando-se do montante transferido para organizações da sociedade apenas no segundo governo Lula; a sensível realocação de recursos de entes federativos para organizações da sociedade civil entre 2007 e 2010, durante os debates em torno da PNSB e da PNRS; o aumento nas transferências de recursos para entes federados no período imediatamente posterior à aprovação da nova legislação, em atendimento ao prazo estabelecido pela nova legislação para municípios e estados elaborarem seus planos de gestão de resíduos sólidos - até agosto de 2012; e, por fim, o baixo volume de recursos destinado às ações dos programas de resíduos sólidos durante o período, representando apenas 0,02\% do total transferido para unidades subnacionais e organizações da sociedade civil.

Gráfico 1: Transferência de Recursos da União Programas RSU e RS (2004-2015)

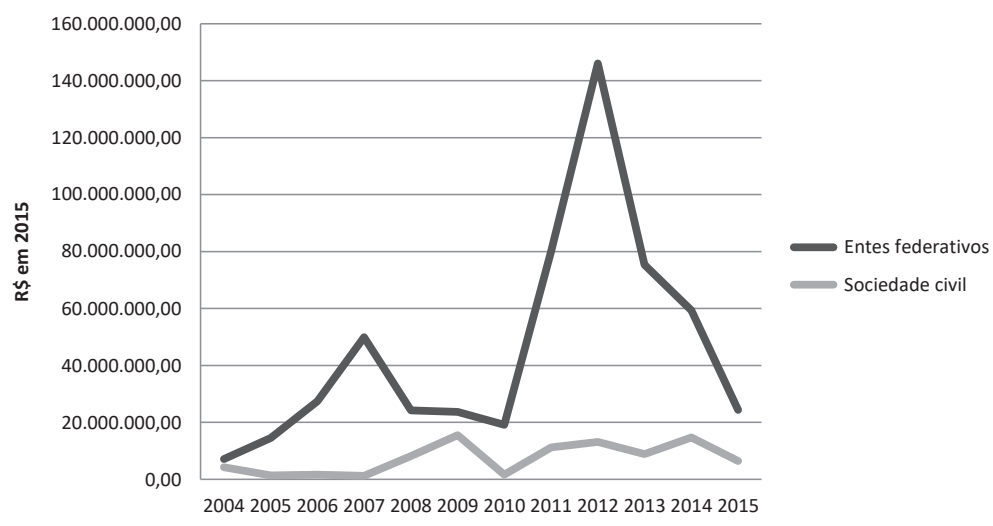

Fonte: Elaboração própria a partir de dados do Portal da Transferência.

${ }^{14}$ Valores corrigidos pelo IPCA - Índice de Preços ao Consumidor, calculado pelo Instituto Brasileiro de Geografia e Estatística (IBGE). 
Na prática, tais recursos contemplaram o financiamento de infraestrutura para a gestão de resíduos, para a contratação de planos de manejo integrado e para o assessoramento técnico à estruturação de associações e cooperativas de catadores no país. A execução de tais ações se deu por meio da articulação entre burocracias da administração pública direta - principalmente SNSA-MCidades, ${ }^{15}$ SQA-MMA, SNAS-MDS, Secretaria Nacional de Segurança Alimentar e Nutricional (Sesan-MDS) e Secretaria Nacional de Economia Solidária (Senaes-MTE) - com organizações da administração indireta, especialmente a FBB, a Funasa, a Petrobras, o BNDES e a Caixa Econômica Federal.

Diferentes convênios foram firmados nesse contexto com o intuito de fortalecer as associações e cooperativas de catadores vinculadas ao MNCR, promovendo encontros nacionais, oferecendo cursos de formação de lideranças em empreendimentos de economia solidária e patrocinando estudos que consolidassem dados para políticas voltadas ao estreitamento de vínculos identitários entre os catadores, ${ }^{16}$ em defesa da narrativa inclusiva que sustentava o modelo Girsu alternativo.

Aqueles atores vinculados à coalizão discursiva Lixo e Cidadania que haviam assumido posições na Saip-MDS mediaram ainda a articulação entre organizações executoras de convênios e o MNCR, para elaborarem um estudo sobre a situação das organizações vinculadas ao movimento, em parceria com o Grupo de Estudos de Relações Intersetoriais da Faculdade de Ciências Econômicas da Universidade Federal da Bahia (Geri-FCE-UFBA) (DAMASIO et al., 2006). O estudo estimou o custo da geração de postos de trabalho para os catadores e, em seguida, passou a ser mobilizado por esses atores para defender a incorporação do modelo Girsu alternativo à legislação federal sobre saneamento e resíduos sólidos.

Em resposta a essa mobilização, Lula e Patrus Ananias promulgaram o Decreto $n^{0}$ 5.940/2006, formalizando o programa piloto de Coleta Seletiva Solidária da Esplanada para toda a administração pública federal.

\footnotetext{
${ }^{15}$ Em 2007, a SQA-MMA se transformou em Secretaria de Recursos Hídricos e Ambiente Urbano (SRHAU).

${ }^{16}$ Informações corroboradas por inúmeros editais de fomento.
} 
Depois, o BNDES anunciou uma linha de financiamento de seu Fundo Social para o fortalecimento de organizações de catadores. Em seguida, foi a vez da Câmara Federal aprovar o texto final da PNSB, sancionada em janeiro de 2007, autorizando a contratação, com dispensa de licitação, de associações e cooperativas de catadores por prefeituras.

Burocratas atuantes no Ciisc, por exemplo, negociaram programas com o MNCR e com organizações de assessoramento técnico a catadores e traduziram ideias em práticas, por meio da canalização de esforços para a realização de eventos e cursos de capacitação para cooperativas e associações de catadores. É nesse contexto que o MNCR formalizou sua associação nacional como braço jurídico para promover assessoramento técnico e executar projetos de fomento voltados à organização política e produtiva dos catadores no país. Convênios dessa natureza financiaram a realização de Festivais Lixo e Cidadania e eventos internacionais Expocatadores. ${ }^{17}$ Nesses encontros, burocratas, especialistas, catadores e apoiadores do MNCR debatiam diferentes dimensões do modelo Girsu alternativo. Essa dinâmica de interação não somente estimulou a circulação de atores e o fortalecimento da narrativa inclusiva que dava suporte ao modelo, mas fomentou o aprendizado sobre a negociação de propostas, a tradução de ideias e a criação de alternativas.

Ainda que os Festivais Lixo e Cidadania e as Expocatadores tenham sido espaços não exclusivos para catadores, eles propiciaram estruturas para que lideranças regionais se reunissem nacionalmente para debater pautas coletivas e posicionamentos em relação à narrativa de apoio ao modelo Girsu alternativo. Embora tais ações possam ser interpretadas dentro de uma perspectiva neoliberal, de fomento à escala econômica das associações e cooperativas como prestadoras de serviços públicos, parte desses recursos foi distribuída dentro de uma narrativa política de fortalecimento do MNCR como organização de movimento social.

Além de carregar ideias e experiências práticas consigo ao longo de suas trajetórias, os especialistas que participaram dos experimentos com o modelo Girsu alternativo nas prefeituras administradas pelo PT (e se

${ }^{17}$ Informações corroboradas pelo Portal da Transparência da União e pelo Siconv. 
articularam, posteriormente, na coalizão discursiva Lixo e Cidadania) se mobilizaram dentro da administração pública federal para defender o modelo de política que criaram. Eles ocuparam cargos em diferentes níveis de governo e migraram entre organizações estatais e não estatais, expandindo suas redes de relações e aprendendo a negociar propostas alternativas perante os constrangimentos do contexto político-institucional vigente. Além disso, mobilizaram recursos para as aprovações de programas, decretos, leis, em suma, um regime de políticas públicas que incorporou o modelo Girsu alternativo, especialmente por meio da Lei Federal n ${ }^{0} 11.445$, da Política Nacional de Saneamento, e da Lei Federal nº 12.305, da Política Nacional de Resíduos Sólidos.

Durante e depois da tramitação das leis, membros do Ciisc realizaram seminários de avaliação para identificar gargalos e definir soluções para a implementação das políticas. Naquelas reuniões, burocratas forneceram informações a catadores para ajudá-los em suas mobilizações, enquanto catadores compartilhavam experiências sobre a implementação de programas com burocratas. Tais encontros propiciaram espaços para a prestação de contas assim como para o aprendizado daqueles atores sobre formas de traduzir ideias em práticas adaptáveis a contextos específicos. Desse aprendizado técnico e político também resultou a criação de alternativas por meio de negociações sobre propostas concretas e da mobilização de recursos em seu suporte.

\section{Conclusão}

Este estudo de caso explicou como trajetórias técnico-políticas incidiram no processo de criação de um modelo alternativo de gestão integrada de resíduos sólidos no Brasil. O efeito Ricochete habilitou especialistas engajados na construção do modelo a elaborar uma narrativa e empregar em seu apoio recursos de maneira criativa, mediando relações entre burocratas, políticos e membros de organizações da sociedade civil. Os três mecanismos que constituíram o efeito foram o aprendizado técnico e político sobre como negociar propostas concretas, criar alternativas contextualizadas e traduzir ideias em soluções práticas; a constituição de redes de relações 
entre atores migrantes entre organizações estatais e não estatais; e a mobilização de recursos humanos e materiais entre a sociedade civil e o Estado, em suporte à narrativa sobre o modelo Girsu alternativo.

Especialistas que participaram de administrações municipais do PT transitaram entre organizações situadas na sociedade civil e no Estado ao longo de suas trajetórias, circulando entre níveis de governo (nacional e internacionalmente). Assim, navegaram por meio das fronteiras entre subsistemas de políticas, habilitando-se a incidir coletivamente na mudança de política que resultou na PNSB e na PNRS. Ao ocuparem cargos em administrações locais e se engajarem na criação de uma narrativa coerente com o apoio de atores da sociedade, tais indivíduos experimentaram uma solução inclusiva para os problemas associados ao modelo de limpeza urbana historicamente vigente no Brasil. Anos depois, alguns desses atores ocuparam cargos na administração pública federal e, de diferentes posições, canalizaram esforços para que aliados internos e externos apoiassem aquela narrativa. Essa mediação pode ser interpretada como ativismo institucional porque reuniu de maneira criativa novos apoiadores do modelo que atuaram para sua incorporação nas Políticas Nacionais de Resíduos Sólidos e de Saneamento.

Depois da implementação das primeiras soluções integradas para a gestão municipal de resíduos sólidos nos anos 1980 e 1990, a inclusão dos catadores passou a constituir o principal elemento da narrativa sobre o modelo Girsu alternativo no nível federal, nos anos 2000. A condução dessa narrativa à escala nacional, por meio da combinação de ideias e práticas em defesa do meio ambiente e da justiça social, teve um marco importante no governo de Fernando Henrique Cardoso, em 2002, com o reconhecimento formal da atividade dos catadores pelo governo federal. A partir de 2003, esforços diversificados de pessoas que mediaram relações nas interfaces do saneamento ambiental e da economia solidária resultaram na criação de institucionalidades e programas em suporte daquele modelo.

Enquanto nos anos FHC a coalizão discursiva Lixo e Cidadania mobilizou a narrativa inclusiva em conjunto com atores da sociedade civil para sensibilizar as burocracias federais e o próprio governo sobre a importância de dedicar atenção e recursos ao tema, nos anos Lula apoiadores daquela narrativa ocuparam posições na administração pública federal, de onde contribuíram significativamente para a escalada do modelo. Diversas táticas 
foram empregadas de maneira exitosa, mesmo diante de limitações impostas pelo contexto político e jurídico- administrativo em que se encontravam.

Embora tenha conseguido o apoio de membros do alto escalão do governo federal em diversos momentos, especialmente do presidente Lula, essa rede de atores confrontou oposições significativas dentro e fora do Estado. Além de ter aprendido a negociar propostas concretas com atores políticos heterogêneos e criar alternativas contextualizadas, esse grupo de pessoas expandiu estrategicamente suas redes de relações e, por meio delas, mobilizou recursos humanos e financeiros para nutrir o apoio de atores estatais e não estatais. Ao longo de três décadas, arquitetaram oportunidades para o fortalecimento de grupos apoiadores da narrativa que sustentava o modelo Girsu alternativo.

Atores cujas trajetórias técnico-políticas se constituíram por múltiplos vínculos derivados da migração entre organizações estatais e não estatais proporcionaram acesso a círculos estatais de confecção de políticas como uma estratégia para cultivar alianças com catadores do MNCR e outros especialistas vinculados a organizações da sociedade. Dessa maneira, grupos de trabalho formados por burocratas e catadores foram criados para discutir estratégias de suporte à aprovação das leis da PNSB e da PNRS, nutridas por convênios e ações orçamentárias destinadas a programas de apoio à organização e mobilização dos catadores do MNCR.

\section{Referências}

ABERS, Rebecca Neaera. Bureaucratic activism: pursuing environmentalism inside the Brazilian state. Latin American Politics and Society, v. 66, n. 2, p. 22-44, mai 2019.

ABERS, Rebecca Neaera et al. Movimentos sociais e políticas públicas: repensando atores e oportunidades políticas. Lua nova: Revista de Cultura e Política, n. 105, p. 15-46, 2018.

ABERS, Rebecca Neaera; KECK, Margaret E. Practical authority: agency and institutional change in Brazilian water politics. Oxford: Oxford University Press, 2013. 
ABERS, Rebecca Neaera; KECK, Margaret E. Autoridade prática: ação criativa e mudança institucional na política das águas do Brasil. Rio de Janeiro: Fiocruz, 2017.

ABERS, Rebecca Neaera; SERAFIM, Lizandra; TATAGIBA, Luciana. Repertórios de interação estado-sociedade em um estado heterogêneo: a experiência na Era Lula. Dados - Revista de Ciências Sociais, Rio de Janeiro, v. 57, n. 2, p. 325-357, 2014.

ABREU, Maria de Fátima. Programa Nacional Lixo e Cidadania: conquistas, desafios e perspectivas. Brasília: MMA/SQA, GTZ, 2002.

ABREU, Maria de Fátima. Do lixo à cidadania: estratégias para a ação. In: Fórum Nacional Lixo e Cidadania. Brasília: Caixa, 2007.

ABREU, Maria de Fátima et al. Processo de constituição do fórum estadual Lixo \& Cidadania em Minas Gerais. In: Trabalhos técnicos. João Pessoa: Abes, 2001.

ANSELL, Christopher K. Pragmatist democracy: evolutionary learning as public philosophy. Oxford; New York: Oxford University Press, 2011. ARAÚJO, Maria Celina Soares d'; LAMEIRÃO, Camila. A elite dirigente do governo Lula. Rio de Janeiro: Fundação Getúlio Vargas, 2009.

BESEN, Gina Rizpah. Coleta seletiva com inclusão de catadores: construção participativa de indicadores e índices de sustentabilidade. 2011. 275 f., il. Tese (Doutorado em Saúde Pública) - Faculdade de Saúde Pública, Universidade de São Paulo, São Paulo, 2011.

BIANCHI, Alvaro; ALIAGA, Luciana. Pareto e Gramsci: itinerários de uma ciência política italiana. Análise social, v. 203, n. 47, p. 322-342, 2012. BIRKBECK, Chris. Self-employed proletarians in an informal factory: the case of Cali's garbage dump. World development, v. 6, n. 9-10, p. 11731185, 1978.

BLUMBERG, Louis; GOTTLIEB, Robert. War on waste: can America win its battle with garbage? Washington, DC: Island Press, 1989. 
BRANDÃO, Igor Ribas. Governar o desperdício: a inclusão de catadores no regime brasileiro de políticas de resíduos. 2018. xi, 245 f., il. Tese (Doutorado em Ciência Política) - Instituto de Ciência Política, Universidade de Brasília, Brasília, 2018.

BRANDÃO, Igor Ribas; GUTIÉRREZ, Ricardo A. Novos Regimes de Políticas de Resíduos na América Latina: Brasil e Argentina em perspectiva comparada. Anais. In: ENCONTRO ANUAL DA ANPOCS, 40., 2016, Caxambu/MG.. Anais...Caxambu/MG: ANPOCS, 2016.

BRANDÃO, Igor Ribas; GUTIÉRREZ, Ricardo A. La emergencia de nuevos regímenes de políticas de residuos sólidos en América Latina: los casos de la Argentina y Brasil. In: SCHAMBER, Pablo Javier; SUÁREZ, Francisco M. Recicloscopio V. Los Polvorines: Universidad Nacional de General Sarmiento, 2018. p. 247-284.

BRANDÃO, Igor Ribas. VILAÇA, Luiz Henrique. Ativismo burocrático na construção de Belo Monte e na inclusão socioprodutiva de catadores de materiais recicláveis. Anais. In: ENCONTRO INTERNACIONAL PARTICIPAÇÃO, DEMOCRACIA E POLÍTICAS PÚBLICAS, 3., 2017, Vitória/ES. Anais [...] Vitória/ES: Universidade Federal do Espírito Santo (UFES), 2017. BRANDÃO, Igor Ribas; VIANA, Rafael Rocha. Reconfigurar a ação pública: ativismo e criatividade política no Programas Cataforte e Minha Casa Minha Vida-Entidades. In: TATAGIBA, Luciana; TEIXEIRA, Ana Cláudia Chaves (org.). Movimentos sociais e políticas públicas. Araraquara: Editora Unesp, 2018 (no prelo).

CARDOSO JR., José Celso; BARBOSA, Sheila Cristina Tolentino. Boletim de análise político-institucional. Brasília: Ipea, 2017.

CARLOS, Euzeneia et al. Movimentos sociais e seus efeitos nas políticas públicas: balanço do debate e proposições analíticas. Civitas: Revista de Ciências Sociais, v. 17, n. 2, p. 360-378, 2017. 
CUNHA, Gabriela Cavalcanti. Economia solidária e políticas públicas: reflexões a partir do caso do programa Incubadora de Cooperativas, da prefeitura municipal de Santo André, SP. 2002. 163 f., il. Dissertação (Mestrado em Ciência Política) - Faculdade de Filosofia, Letras e Ciências Humanas, Universidade de São Paulo, São Paulo, 2002.

CUNHA, Gabriela Cavalcanti. Outras políticas para outras economias: contextos e redes na construção de ações do governo federal voltadas à economia solidária (2003-2010). 2012. 472 f., il. Tese (Doutorado em Ciência Política) - Instituto de Ciência Política, Universidade de Brasília, Brasília, 2012.

DAMASIO, Joao et al. Análise do custo de geração de postos de trabalho na economia urbana para o segmento dos catadores de materiais recicláveis. Salvador: Universidade Federal da Bahia, 2006.

DEMAJOROVIC, Jacques. Da política tradicional de tratamento do lixo à política de gestão de resíduos sólidos: as novas prioridades. Revista de Administração de Empresas, v. 35, n. 3, p. 88-93, 1995.DEMAJOROVIC, Jacques; LIMA, Márcia. Cadeia de reciclagem: um olhar para os catadores. São Paulo: Edições SESC, 2013.

DIAS, Sonia Maria. Construindo a cidadania: avanços e limites do projeto de coleta seletiva em parceria com a ASMARE. 2002. 204 f., il. Dissertação (Mestrado em Geografia) - Instituto de Geociências, Universidade Federal de Minas Gerais, Belo Horizonte, 2002.

DIAS, Sonia Maria. Trajetórias e memórias dos Fóruns Lixo e Cidadania no Brasil: experimentos singulares de justiça social e governança participativa. 2009. 391 f., il. Tese (Doutorado em Ciência Política) - Faculdade de Filosofia e Ciências Humanas, Universidade Federal de Minas Gerais, Belo Horizonte, 2009.

FERRO, Maria Carolina Tiraboschi. Desafíos de la participación social: alcances y límites de la construcción de la Política Nacional para la Población en Situación de Calle en Brasil. Buenos Aires: Flacso, 2011. 
FISCHER, Frank. Democracy and expertise: reorienting policy inquiry. Oxford: Oxford University Press, 2009.

FISCHER, Frank. Reframing public policy. Oxford: Oxford University Press, 2003.

GONÇALVES-DIAS, Sylmara L. F. Catadores: uma perspectiva de sua inserção no campo da indústria de reciclagem. 2009. 298 f., il. Tese (Doutorado em Ciência Ambiental) - Programa de Pós-graduação em Ciência Ambiental, Universidade de São Paulo, São Paulo, 2009.

GRIMBERG, Elisabeth. Estudo sobre a Cooperativa de Catadores Autônomos de Papel, Aparas e Materiais Reaproveitáveis (Coopamare) de São Paulo. São Paulo: Instituto Pólis, 1994.

GRIMBERG, Elisabeth; BLAUTH, Patrícia. Coleta seletiva de lixo: reciclando materiais, reciclando valores. São Paulo: Instituto Pólis, 1998.

GUTBERLET, Jutta. Recovering resources, recycling citizenship: urban poverty reduction in Latin America. Aldershot: Ashgate, 2008.

GUTIERRES, Kellen Alves. Estudo de trajetórias e interações socioestatais: mútua constituição entre movimento social e a política pública de assistência social. Lua Nova: Revista de Cultura e Política, n. 105, p. 81-114, 2018. GUTIÉRREZ, Ricardo A. When experts do politics: introducing water policy reform in Brazil. Governance, v. 23, n. 1, p. 59-88, 2010.

HAJER, Maarten A. Discourse coalitions and the institutionalization of practice: the case of acid rain in Great Britain. In: FISCHER, Frank; FORESTER, John (org.). The argumentative turn in policy analysis and planning. London: UCL Press, 1993. p. 43-76.

HOWLETT, Michael; MUKHERJEE, Ishani; KOPPENJAN, Joop. Policy learning and policy networks in theory and practice: the role of policy brokers in the Indonesian biodiesel policy network. Policy and society, v. 36, n. 2, p. 233-250, 2017. 
INGOLD, Karin; VARONE, Frédéric. Treating policy brokers seriously: evidence from the climate policy. Journal of public administration research and theory, v. 22, n. 2, p. 319-346, 2012.

JACOBI, Pedro Roberto (org.). Gestão compartilhada dos resíduos sólidos no Brasil: inovação com inclusão social. São Paulo: Annablume, 2006.

JACOBI, Pedro Roberto; TEIXEIRA, Marco Antonio Carvalho. Criação do capital social: o caso Asmare (Associação dos Catadores de Papel, Papelão e Material Reaproveitável de Belo Horizonte). Cadernos de gestão pública e cidadania, v. 2, p. 5-49, 1997.

JENKINS-SMITH, Hank et al. Belief system continuity and change in policy advocacy coalitions: using cultural theory to specify belief systems, coalitions, and sources of change. Policy studies journal, v. 42, n. 4, p. 484-508, 2014.

KINGDON, John W. Agendas, alternatives, and public policies. New York: Longman, 1995.

KNAGGÅRD, Åsa. The multiple streams framework and the problem broker. European journal of political research, v. 54, n. 3, p. 450-465, 2015. KREITH, Frank; TCHOBANOGLOUS, George (org.). Handbook of solid waste management. New York: McGraw-Hill, 2002.

LIMA, Jacob Carlos. O trabalho autogestionário em cooperativas de produção: o paradigma revisitado. Revista Brasileira de ciências sociais, v. 19, n. 56, p. 45-62, 2004.

LOPEZ, Felix Garcia; BUGARIN, Mauricio Soares; BUGARIN, Karina. Turnover of political appointments in Brazil: key indicators 1999-2012. International journal of cooperation studies, v. 22, p. 109-120, 2014.

LUTON, Larry S. The politics of garbage: a community perspective on solid waste policy making. Pittsburgh, PA: University of Pittsburgh Press, 1996. 
MAGERA, Márcio. Os empresários do lixo: um paradoxo da modernidade. [S.l.]: Editor Átomo, 2003.

MARTINS, Clitia Helena Backx. Trabalhadores na reciclagem do lixo: dinâmicas econômicas e políticas na perspectiva de empoderamento. 2003. 210 f., il. Tese (Doutorado em Sociologia) - Instituto de Filosofia e Ciências Humanas, Universidade Federal do Rio Grande do Sul, Porto Alegre, 2003. MNCR. Política Nacional de Resíduos e o Movimento Nacional dos Catadores de Materiais Recicláveis. In: JARDIM, Arnaldo; YOSHIDA, Consuelo Yatsuda Moromizato; MACHADO FILHO, José Valverde (org.). Política nacional, gestão e gerenciamento de resíduos sólidos. São Paulo: Manole, 2012.

OLIVEIRA, Marília Silva de. Movimento para as instituições: movimento ambiental, partidos políticos e a liderança de Marina Silva. 2016. 303 f., il. Tese (Doutorado em Ciência Política) - Instituto de Ciência Política, Universidade de Brasília, Brasília, 2016. PEREIRA, Maria Cecília Gomes; TEIXEIRA, Marco Antonio Carvalho. A inclusão de catadores em programas de coleta seletiva: da agenda local à nacional. Cadernos EBAPE.BR, v. 9, n. 3, p. 895-913, 2011.

PETERS, B. Guy; ZITTOUN, Philippe (org.). Contemporary approaches to public policy. London: Palgrave Macmillan, 2016.

PHILIPPI JR., Arlindo et al. Gestão integrada de resíduos sólidos. In: JARDIM, Arnaldo; YOSHIDA, Consuelo Yatsuda Moromizato; MACHADO FILHO, José Valverde (org.). Política nacional, gestão e gerenciamento de resíduos sólidos. Barueri, SP: Manole, 2012. p. 229-244. PORTO DE OLIVEIRA, Osmany. International policy diffusion and participatory budgeting. Cham: Springer International Publishing, 2017.

RICH, Jessica A. J. State-sponsored activism: bureaucrats and social movements in democratic Brazil. Cambridge: Cambridge University Press, 2019. 
SABATIER, Paul A. An advocacy coalition framework of policy change and the role of policy-oriented learning therein. Policy sciences, v. 21, n. 2-3, p. 129-168, 1988.

SCHAMBER, Pablo Javier; SUÁREZ, Francisco Martín (org.). Recicloscopio: miradas sobre recuperadores urbanos de residuos de América Latina. Los Polvorines: Universidad Nacional de General Sarmiento: Prometeo Libros, 2007. SCHEINBERG, Anne. The proof of the pudding: urban recycling in North America as a process of ecological modernisation. Environmental politics, v. 12, n. 4, p. 49-75, 2003.

SCHEINBERG, Anne; ANSCHTZ, Justine. Slim pickin's: supporting waste pickers in the ecological modernization of urban waste management systems. International journal of technology management \& sustainable development, v. 5, n. 3, p. 257-270, 2006.

SCHERER-WARREN, Ilse. Fóruns e redes da sociedade civil: percepções sobre exclusão social e cidadania. Política e sociedade, v. 11, p. 19-40, 2007. SCHIOCHET, Valmor. Economia solidária no Brasil: da democracia à autogestão. In: PHILIPPI JR., Arlindo (org.). Gestão de natureza pública e sustentabilidade. São Paulo: Manole, 2012. p. 985-1006.

SCHNEIDER, Ben. Burocracia pública e política industrial no Brasil. São Paulo: Sumaré, 1994.

SILVA, Marcelo Kunrath; OLIVEIRA, Gerson de Lima. A face oculta(da) dos movimentos sociais: trânsito institucional e intersecção Estado-Movimento - uma análise do movimento de economia solidária no Rio Grande do Sul. Sociologias, v. 13, n. 28, p. 86-124, 2011.

SILVA, Sandro Pereira. A organização coletiva de catadores de material reciclável no Brasil: dilemas e potencialidades sob a ótica da economia solidária. Rio de Janeiro: Ipea, 2017.

SILVA, Sandro Pereira et al. Situação social das catadoras e dos catadores de material reciclável e reutilizável. Brasília: Ipea, 2013. 
SOTO, Magda Martina Tirado. Análise e formação de redes de cooperativas de catadores de materiais recicláveis no âmbito da economia solidária. 2011. xiv, 214 f., il. Tese (Doutorado em Engenharia da Produção) - Instituto Alberto Luiz Coimbra de Pós-Graduação e Pesquisa de Engenharia, Universidade Federal do Rio de Janeiro, Rio de Janeiro, 2011.

SOUZA, Clóvis Henrique Leite de. Capacidades estatais para a promoção de processos participativos: uma análise da forma de organização de conferências nacionais. 2016. 194 f., il. Tese (Doutorado em Ciência Política) - Instituto de Ciência Política, Universidade de Brasília, Brasília, 2016. STONE, Deborah A. Causal stories and the formation of policy agendas. Political science quarterly, v. 104, n. 2, p. 281-300, 1989.

STONE, Deborah A. Policy paradox: the art of political decision making. New York: W.W. Norton \& Co, 2012.

ZAHARIADIS, Nikolaos. Ambiguity and multiple streams. In: ZAHARIADIS, Nikolaos. Theories of the policy process. Boulder, CO: Westview Press, 2014. p. 25-58.

ZITTOUN, Philippe. The political process of policymaking: a pragmatic approach to public policy. [S.l.]: Springer, 2014. 


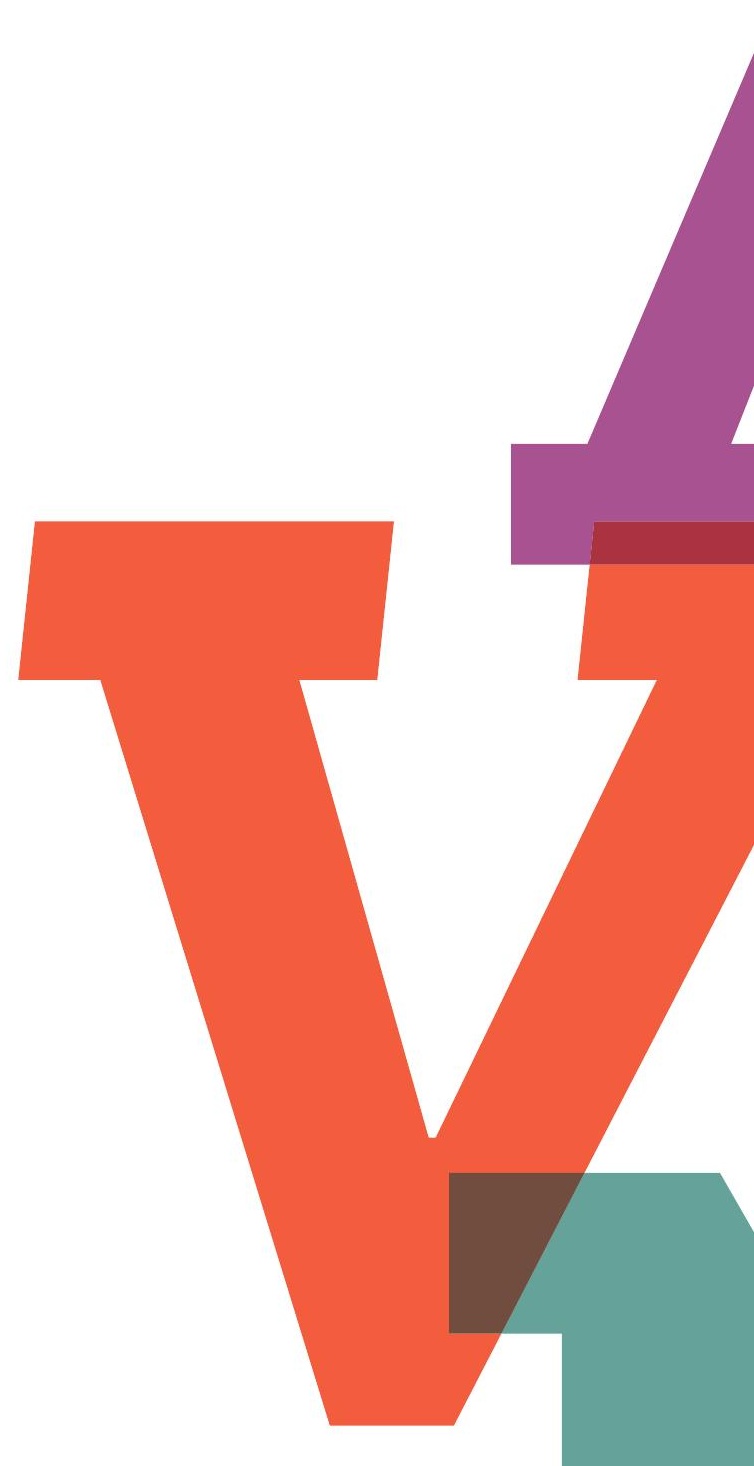




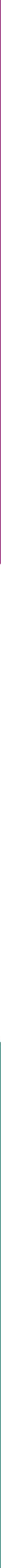




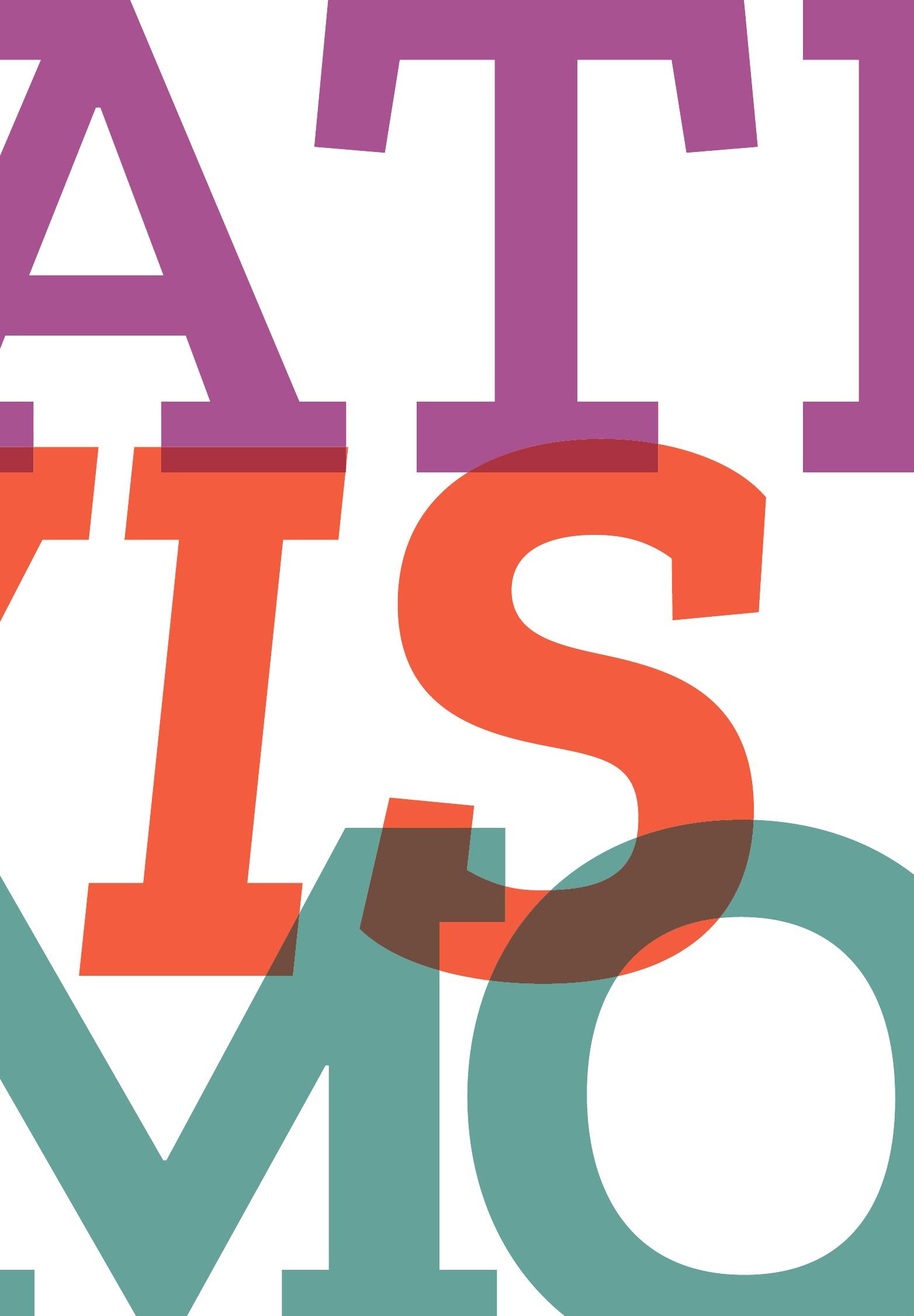




\section{Capítulo 3}

\section{Movimentos sociais,}

ocupação de cargos públicos e políticas públicas: uma relação de sucesso. $\bigcirc$ caso da produção do Plano de Prevenção e Combate ao Desmatamento na Amazônia - PPCDAM

Marília Silva de Oliveira

Entre os anos 2004 e 2014, o Brasil assistiu a um fenômeno improvável: a redução em 82,5\% da taxa de desmatamento florestal na Amazônia. Tal feito é avaliado como resultado de um investimento dedicado e ostensivo da equipe do Ministério do Meio Ambiente (MMA), a qual mobilizou esforços e conseguiu compromisso e apoio de outras áreas do governo - principalmente da Casa Civil da Presidência da República - para a elaboração e implementação 
do Plano de Prevenção e Combate ao Desmatamento na Amazônia (PPCDAm) e de outras medidas de contenção do desmatamento no bioma.

O PPCDAm foi criado em 2004, quando o registro da taxa de desmatamento na Amazônia chegou ao pico de $27.772 \mathrm{~km} 2$. Ainda que o sucesso da política tenha sido bastante comemorado (OLIVEIRA, 2016), ao longo desses 10 anos a base de apoio governamental ao plano variou diante de desafios e embates provocados por outros setores governamentais. Alguns deles expressavam abertamente interesses contrários àqueles necessários para promover a preservação da Amazônia, região para onde a agropecuária avança(va) sem freios, provocando novos desmatamentos e, por vezes, anulando o investimento da política florestal naquele bioma, assim como em outros. Ocorreram também oscilações importantes na dinâmica governamental e ameaças ao projeto político do partido no governo que afetaram sobremaneira a implementação do PPCDAm.

Diante desse cenário, como a equipe ambiental conseguiu elaborar e implementar a política de maior importância na área ambiental? Como conseguiu se sobressair num processo de disputas de projetos políticos internas ao governo? O argumento defendido é o de que os ambientalistas, egressos de organizações da sociedade civil, ao ocuparem cargos no MMA levaram suas experiências e conhecimentos para o governo e os aproveitaram para desenhar e implementar políticas públicas inovadoras. Com o PPCDAm, eles construíram um modelo alternativo de política pública com o envolvimento de diferentes atores e setores da sociedade, um modelo ausente na burocracia estatal calcado em conhecimento técnico e de causa que refletia um trabalho dedicado de mapeamento da região.

Se antes os ambientalistas tentavam influenciar o governo desde seus lugares na sociedade civil, agora, ocupando cargos de direção no MMA, eles próprios seriam os executores de suas propostas. Porém, no caso do PPCDAm, foi necessário juntar a capacidade técnica dos ambientalistas com uma capacidade político-partidária, garantida pela forte liderança de Marina Silva, que possuía poder de influência tanto dentro do movimento ambientalista quanto, principalmente, dentro de sua legenda partidária de então, o Partido dos Trabalhadores, que ocupava o governo no período analisado nesta pesquisa. 
Marina Silva foi nomeada Ministra do Meio Ambiente e trouxe importantes lideranças do movimento ambiental para assumir cargos no Ministério. As interações prévias de atores do movimento ambientalista com o sistema político, com o Partido dos Trabalhadores e, sobretudo, com Marina Silva foram decisivas para que acessassem o Estado de uma nova maneira e implementassem o PPCDAm. Foi observado que o funcionamento do subsistema da política ambiental, que conecta atores dos diferentes campos social, político e estatal, e a abertura do sistema político (ou regime) para os ambientalistas foram também elementos cruciais para que um novo modelo de políticas públicas pudesse ser implementado pelos ambientalistas no governo do Partido dos Trabalhadores.

O objetivo deste estudo é, portanto, analisar o processo de elaboração e implementação do PPCDAm a partir dos atores, que produziram o plano e foram responsáveis por ele durante os anos 2003 e 2008, e de suas trajetórias profissionais. No período em questão, Marina Silva foi Ministra do Meio Ambiente e formou uma equipe com fortes vínculos com atores da sociedade civil. A proposta é vincular o perfil dos responsáveis pela política pública com as características dessa política, defendendo que o PPCDAm é resultado de um projeto político compartilhado entre os atores egressos do movimento ambientalista e a líder sociopartidária Marina Silva. ${ }^{1}$

Os principais responsáveis por essa política foram lotados inicialmente na Secretaria de Biodiversidade e Florestas (SBF) e, a partir de 2007, na Secretaria Executiva do MMA. Por isso, os perfis profissionais observados serão principalmente dos ocupantes de cargos de Direção e Assessoramento Superior (DAS), níveis 5 e 6, nessas secretarias. Esses cargos correspondem à elite dirigente de um ministério (D’ARAÚJO, 2009). O nível DAS 6 corresponde ao primeiro escalão de funcionários, ou seja, os secretários que estão logo abaixo do ministro de Estado. O secretário-executivo é uma nomeação especial, mas aqui entra na lista de secretários. Já o nível DAS 5 se refere ao cargo de diretor de departamentos das secretarias. Os cargos

1 De acordo com Oliveira (2016), uma liderança sociopartidária é aquela que ativa os mecanismos de liderança (cf. MELUCCI, 1996) nos movimentos sociais e também exerce importante liderança na organização partidária a que pertence. 
DAS de níveis 4, 3, 2 e 1 são de caráter técnico e administrativo, enquanto os de níveis 5 e 6 são políticos.

Em 2005, o decreto federal $n^{\circ} 5.497$ estabeleceu que deveriam ser servidores públicos $75 \%$ dos nomeados a cargos DAS 1 a 3 e $50 \%$ dos nomeados a cargos DAS 4. Essas regras não incorrem sobre os níveis mais políticos, de maneira que os DAS 5 e 6 são considerados de livre nomeação. Apesar dessa liberdade, Lopez e Praça (2015a) observaram que a grande maioria da elite dirigente ou elite política dos ministérios é composta por burocratas de carreira do funcionalismo público.

Após identificar os secretários e diretores nomeados para a SBF e a Secretaria-Executiva, ${ }^{2}$ foram feitas buscas na internet com o objetivo de identificar as trajetórias profissionais desses atores. Por se tratarem de pessoas com reconhecida atuação na área ambiental e com formação acadêmica relevante, não foi difícil encontrar informações sobre suas experiências profissionais. Esse processo foi complementado por 43 entrevistas realizadas pela pesquisadora entre 2013 e 2015.

Além desta introdução, o capítulo está dividido em três partes. Primeiramente, é desenvolvida uma discussão com a literatura sobre ocupação de cargos públicos e sobre políticas públicas, com foco nas inovações que movimentos sociais, ao ocuparem cargos da elite dirigente das agências públicas, levam para a estrutura estatal e para as políticas públicas. Na sequência, o processo de ocupação de cargos públicos é descrito, considerando os elementos que possibilitaram que secretários e diretores fossem nomeados para o MMA. Conhecendo o perfil da elite dirigente do ministério, parte-se para a análise da elaboração e implementação do PPCDAm. Por fim, conclui-se que foram fundamentais para a implementação da política de maior sucesso na área ambiental: um regime político aberto e favorável para a ação de movimentos sociais, um subsistema de política pública que incluiu atores de diferentes setores, militantes de movimentos sociais com capacidades técnicas escassas na estrutura estatal, e a ação de uma líder sociopartidária, Marina Silva.

2 Agradeço ao Instituto de Pesquisa Econômica Aplicada (Ipea) que disponibilizou base de dados com os nomes de ocupantes de cargos DAS no MMA de 1999 a 2012. 
Este estudo contribui para o debate sobre ativismo institucional a partir do olhar analítico do perfil dos nomeados à elite dirigente do MMA. Mais especificamente, examina ativismo no sentido de ocupação de cargos públicos por pessoas oriundas de movimentos sociais. De acordo com a literatura sobre política de ocupação de cargos públicos, há dois perfis que sobressaem nas nomeações da elite dirigente dos órgãos estatais: o burocrata (capacidade técnica) e o político (capacidade política) (LOPEZ, 2015). Na ausência de capacidade política e/ou técnica burocrática, outros perfis podem ser acessados pelo Presidente da República a fim de compor sua equipe governamental. Nesse sentido, o caso aqui apresentado traz uma experiência interessante, pois trata tanto da busca do novo governo pelo perfil adequado dentro do movimento ambientalista quanto da ação de lideranças desse movimento para influenciar políticas públicas a partir da ocupação de cargos públicos. Um caso clássico de ativismo institucional.

\section{Ocupação de cargos públicos}

A ocupação de cargos de direção nas instituições públicas brasileiras é envolta em disputas e negociações por parte do governo e seus aliados, uma vez que influencia as diretrizes políticas, a implementação de políticas públicas, a dinâmica de relações entre os poderes Executivo e Legislativo e as interações entre Estado e sociedade (D’ARAÚJO, 2009; LOPEZ et al. 2013; LOPEZ, 2015). Os dirigentes exercem, dessa forma, controle sobre o sistema político, notabilizando a nomeação de dirigentes do governo como um dos principais recursos de divisão de poder na administração pública (LOPEZ et al., 2013). A articulação do chefe do governo, nesse sentido, é crucial para exercer o máximo possível de controle sobre o processo de formação de sua burocracia a fim de criar a estrutura que melhor atenderá a seu projeto político.

No Brasil, a disposição de cargos em níveis de DAS obedece à lógica do presidencialismo de coalizão. Com a prerrogativa e poder de coordenar as nomeações, o presidente eleito negocia apoio no Congresso Nacional, fornecendo cargos na burocracia federal aos partidos de sua base aliada, tentando, em contrapartida, formar uma coalizão que o apoie. Existe, desse 
modo, um trade-off entre controle partidário de agências governamentais e apoio partidário no Congresso (LOPEZ; PRAÇA, 2015b).

Tradicionalmente, as abordagens sobre ocupação de cargos públicos no país, no nível da elite dirigente, evidenciam dois perfis recorrentes de nomeações: o burocrata e o político (LOUREIRO et al., 2010). Para manter a autonomia do governo em relação a grupos específicos e diminuir os riscos de práticas de clientelismo e patronagem na administração pública, nomear burocratas com desenvolvida capacidade técnica é desejável (GEDDES, 1990). Porém, num sistema político caracterizado pela necessidade do chefe do poder Executivo de construir e buscar apoio da base aliada no poder Legislativo, a ocupação de cargos públicos pelo perfil político é imperativa (RAILE; PEREIRA; POWER, 2011). Essa prática gera conflitos e demanda do governo estratégias claras para a composição dos órgãos federais (LOUREIRO et al., 2010).

Geddes (1990) observou que as composições geralmente são guiadas por estratégia mista, estruturando alguns órgãos com predominância de perfil político e outros com características mais burocráticas. O político também pode optar por uma composição ainda mais diversificada em que os dirigentes podem vir de outras filiações institucionais, como de movimentos sociais, do setor privado, de sindicatos, dentre outras organizações da sociedade civil (D’ARAÚJO, 2009). Esse último perfil pode predominar em órgãos esvaziados de estrutura burocrática e cujos dirigentes habilitados tecnicamente se encontram na sociedade (HOCHSTETLER; KECK, 2007; LOPEZ; PRAÇA, 2015b).

A incorporação sistemática de lideranças sociais, de representantes de sindicatos e de outras organizações da sociedade civil em cargos da administração federal é uma prática recente no Brasil, utilizada desde que o Partido dos Trabalhadores chegou à Presidência da República em 2003 (D’ARAÚJO, 2009; ABERS; OLIVEIRA, 2015). Ainda assim, ela se concentrou em órgãos específicos da área social do governo (ABERS et al., 2014). A ocupação de cargos públicos por esses novos atores evidenciou a importância das redes e conexões entre atores sociais e políticos para a composição da burocracia federal. Com essa dinâmica, as fronteiras que teoricamente separavam atores sociais de atores estatais se tornaram assaz 
porosas e propuseram olhares mais diversificados para a política de ocupação de cargos públicos. ${ }^{3}$

Dentro da proposta de análises diversificadas sobre a composição do Estado, Marques (2006), ao observar burocracias no nível estadual, percebeu em seu interior estruturas de médio alcance que conformam atores diversos articulados em redes, acessando os instrumentos, recursos e dinâmicas próprias de um campo político específico, o qual ele veio a chamar de policy networks. Essas estruturas são formadas por elementos que se influenciam mutuamente, quais sejam: um conjunto articulado de atores, instituições públicas e padrões de relação (redes). As estruturas são dinâmicas, construídas historicamente e dependentes do contexto em que se inserem para adquirirem forma. Para o autor, elas compõem um denso tecido relacional no interior do Estado que "emoldura a dinâmica política e influencia fortemente a formulação e implementação de políticas públicas” (MARQUES, 2006, p. 15).

Marques apresentou um modelo de Estado relacional onde existe uma complexidade de interações sociais e organizacionais compondo as burocracias, o que afeta diretamente o processo das políticas públicas. A política de ocupação de cargos públicos pode ser analisada e explicada a partir de dinâmicas que não estão apenas relacionadas aos compromissos e acordos (formais ou informais) entre poderes Executivo e Legislativo, mas também em função de dinâmicas próprias e intrínsecas ao campo da política, aos atores e instituições envolvidas em interações que ocorrem em um contexto específico. Nesse sentido, o autor nos convida a observar a composição do Estado para além da análise dos atores tradicionais e a observar a influência que a burocracia estatal, envolvida em suas redes, exerce sobre as políticas públicas.

Abers et al. (2014) observaram que a ocupação de cargos públicos por militantes de movimentos sociais que levaram suas bandeiras na sociedade civil para o interior do Estado possibilitou experimentações com diferentes resultados, a depender das relações historicamente empreendidas entre os distintos grupos da sociedade civil e atores do Estado em cada setor, o que

3 Ver estudos como Abers e Oliveira (2015), Abers e Tatagiba (2015) e Oliveira (2016). 
reforça o argumento de Marques (2006). Elas argumentam que os ativistas, além de se esforçarem para construir e fortalecer espaços participativos, experimentaram variadas formas e canais de comunicação e negociação entre Estado e representantes de movimentos sociais. As autoras reconhecem que há uma composição estatal para além do perfil burocrático/político, e que os setores têm suas especificidades. Sugerem, ainda, uma diversificação de canais de interação na estrutura estatal que contribue para o fortalecimento do aspecto relacional do Estado. Nesse espaço de múltiplas práticas de interações socioestatais, os movimentos sociais exercem papel importante.

Os movimentos sociais podem ser definidos como um tipo de rede (DIANI, 1992; MELUCCI, 1996; DIANI, BISON, 2010) que, ao atravessarem as fronteiras do Estado e ocuparem cargos públicos, refletem suas redes constituintes no ambiente estatal. Eles podem atuar na burocracia referenciados num conjunto de interações confrontacionais que expressam "disputas relacionadas à forma de organização da vida em sociedade” (TATAGIBA et al., 2018, p. 108). Os autores defendem que movimentos sociais influenciarão o processo de produção das políticas públicas a partir dos seguintes aspectos: construção de modelos alternativos de políticas públicas ${ }^{4}$ e disputa entre modelos de políticas públicas com conflitos sobre as próprias instituições. Defendem, ainda, que a atuação dos movimentos sociais e os resultados alcançados são condicionados por três elementos: características do regime, dos subsistemas de políticas públicas e dos movimentos sociais.

Para Tatagiba et al. (2018), uma vez que as políticas públicas são construídas por meio de processos ideacionais, experimentais e relacionais, o que os movimentos sociais vivenciam enquanto sociedade civil será relevante para o processo de produção das políticas públicas, uma vez que se tornam os atores que as pensam e direcionam sua implementação. Quando esses atores assumem cargos de direção nas instituições públicas, carregando suas práticas políticas, experiências e redes para dentro do Estado, diversificam o processo de produção das políticas para além das abordagens

4 São estruturas ideacionais que buscam traduzir as ideias que conformam o projeto político do movimento em propostas de política pública. 
estritamente técnica (burocrática) ou político-partidária, podendo alcançar, dessa forma, uma legitimidade social renovada.

Conhecer o perfil dos responsáveis pela construção e implementação das políticas públicas se mostra relevante. Schneider (1994) assinala que o processo das políticas públicas terá racionalidades distintas em função da composição da aliança que elabora as diretrizes políticas. ${ }^{5}$ Devido à centralidade ocupada pelos burocratas, expõe o autor, é importante compreender quem eles são, de onde vêm, a educação que tiveram e a experiência profissional desenvolvida. Esses elementos são considerados fundamentais para compreender os impactos concretos desses dados sobre as políticas públicas (SCHNEIDER, 1994, p. 37).

Ao agrupar os diferentes argumentos anteriormente trazidos, deparamo-nos com os seguintes elementos para direcionar a análise empírica de implementação do PPCDAm: i) a composição de cargos públicos no Brasil é um processo de distribuição de poder que influencia o processo de produção das políticas públicas; ii) o Estado é uma estrutura relacional onde diversos atores se articulam em rede seguindo as dinâmicas próprias de um campo político específico; iii) a análise da ocupação de cargos públicos por militantes de movimentos sociais revela que suas bandeiras e projetos políticos são levados para o interior do Estado, possibilitando experiências com diferentes resultados, como a disputa e a construção de modelos alternativos de políticas públicas que refletem as relações historicamente engendradas entre Estado e sociedade; e, por fim, iv) a atuação dos movimentos sociais e resultados alcançados são condicionados pelas características do regime, dos subsistemas de políticas públicas e pelas características dos movimentos sociais.

5 Schneider (1994) analisa as carreiras de burocratas, em um exame mais amplo e estrutural do que a simples ocupação de cargos DAS de alto escalão, e seus efeitos para o processo de produção de políticas públicas no setor industrial brasileiro. Não analisamos carreiras burocráticas, mas os elementos destacados pelo autor nos serão úteis para compreender o desenho e implementação de políticas públicas na área ambiental por grupos que ocupam cargos políticos de direção na estrutura estatal. 


\section{Composição da Secretaria de Biodiversidade e Florestas do MMA}

A nomeação de Marina Silva como Ministra do Meio Ambiente foi celebrada pelo movimento ambientalista como um ato de muitos significados (ABERS; OLIVEIRA, 2015) por se tratar da segunda pessoa da equipe presidencial a ser indicada para um Ministério - a primeira havia sido Antonio Palocci, escolhido para chefiar a pasta econômica. Marina era a principal representante da causa ambiental no PT e essa seria a primeira vez que o Ministério ficaria sob a responsabilidade do partido no governo. Isto é, o partido se decidiu pelo controle governamental dessa agenda política. Ademais, Marina era uma importante referência nacional e internacional na luta pela proteção do meio ambiente e promoção do desenvolvimento sustentável, além de relevante parlamentar para o Partido dos Trabalhadores.

Ambientalistas, muitos dos quais participaram da preparação e elaboração do programa de governo do PT, enviaram uma carta ao presidente eleito solicitando a escolha de Marina Silva como responsável pela agenda ambiental. Ao todo, 140 organizações ambientalistas - apoiadas por cientistas, pesquisadores, representantes do setor empresarial e políticos que também assinaram a carta (OLIVEIRA, 2016) - se articularam em torno do documento. Dessa forma, parecia que os anseios políticos de parte do ambientalismo se realizavam da melhor maneira possível, pois Marina representava a possibilidade de implementação do projeto que vinha sendo compartilhado entre atores sociais e políticos.

Nas eleições de 2002, Marina Silva fora reeleita senadora da república pelo estado do Acre, onde iniciou sua militância política ao lado do seringueiro Chico Mendes. Após a morte de Mendes em 1988, Marina tomou para si a responsabilidade de dar continuidade à sua luta. Chico Mendes criou o Partido dos Trabalhadores naquele estado, o mesmo partido em que Marina faria sua história política até 2009 (OLIVEIRA, 2016). Em seu primeiro mandato no Senado, ela praticou um "legislar coletivo" (Entrevista 19, 7/3/2014), com o envolvimento de várias lideranças do movimento ambientalista e organizações da sociedade civil. Esses atores davam respaldo técnico a seus projetos e apoio político para as causas ambientais, ao passo que Marina Silva fazia a defesa de suas bandeiras e a representação política na Casa Legislativa, conforme narrou entrevistado: 
Marina tinha uma relação muito direta com a sociedade civil no âmbito do mandato do Senado [...] ela era, digamos, o porto seguro das nossas demandas no Senado, assim como nós éramos o aparato, o apoio dela, muitas vezes, de produção de subsídios, de propostas, de pareceres para a atuação dela. (Entrevista 2, 24/4/2013).

Após ser indicada ao posto de Ministra do Meio Ambiente, Marina Silva procurou organizações ambientalistas e os nomes mais expressivos da área para compor sua equipe, combinando esse perfil com o de representantes de seu partido com atuação na área ambiental (Entrevista 19, 7/3/2014). Os ambientalistas, por sua vez, também se articulavam para auxiliar o novo governo: após a indicação de Marina ao MMA, eles iniciaram articulações e discussões para a montagem da equipe ministerial (Entrevista 2, 27/4/2013).

Em dezembro de 2002, a nova ministra convocou uma grande reunião em Brasília com ativistas ambientais de diferentes frentes - partido, sociedade, governo, universidade - com a intenção de discutir sobre o cenário da política ambiental brasileira e sobre a nova estrutura do MMA. Na ocasião, também discutiram e indicaram pessoas estratégicas para cargos no Ministério que compartilhavam os ideais praticados por Marina Silva (Entrevista 37, 25/4/2014). Essa dinâmica sinaliza para um padrão de nomeações diferente, em que a organização da elite dirigente ambiental é discutida com lideranças ambientalistas de diferentes representações, em vez de concentrar apenas nas demandas partidárias ou no núcleo do governo. Demonstra igualmente um sistema político (regime) aberto para a influência de movimentos sociais.

O Instituto Socioambiental (ISA) assumiu a liderança da articulação política entre governo e movimento ambientalista, funcionando como um broker. ${ }^{6}$ Entre suas práticas políticas estratégicas, a ONG prezava pela indicação de pessoas de seus quadros para ocuparem cargos no poder público.

6 Broker: um ator que conecta outros atores que não estão diretamente relacionados um com o outro (DIANI, 2003, p. 107). 
O objetivo não era apenas ter um infiltrado no governo, mas cumprir a missão de implementar uma proposta. Entrevistado relatou que:

Nós, do ISA, sempre tivemos uma clareza de que fazia parte da nossa estratégia política contribuir com quadros em diferentes posições do poder público. [...] Quando a Marina foi para o Ministério, a gente imaginava que em algum momento viria uma demanda para cima de nós. [...] ao ceder quadros para o governo, você está cedendo quadros que foram formados em cima de uma história e de uma proposta, e a lógica da ida dessas pessoas para o governo é a consolidação dessa proposta, não uma trajetória individual. (Entrevista 2, 24/4/2013).

Conforme esperado, Marina Silva procurou a instituição para assumir uma secretaria no MMA. A ONG entendeu que sua contribuição seria na área de biodiversidade e florestas, porque era onde tinha uma pauta definida. Estabeleceram que não assumiriam nenhuma outra secretaria que não fosse nessa área. O ISA vinha articulando o processo de divulgação e proposição para implementação política das recomendações do Seminário de Macapá, realizado em 1999.

Esse seminário ocorreu no âmbito do subprojeto “Avaliação e identificação de ações prioritárias para a conservação, utilização sustentável e repartição de benefícios na Amazônia brasileira” coordenado por João Paulo Capobianco, um dos fundadores do ISA, e financiado pelo MMA, por meio do Projeto de Conservação e Utilização Sustentável da Biodiversidade Brasileira (Probio). Nesse período, o MMA era chefiado por José Sarney Filho e estava nas mãos do governo de Fernando Henrique Cardoso do Partido da Social Democracia Brasileira (PSDB), legenda cujo PT era principal opositor.

A coordenação do projeto possibilitou a Capobianco realizar um diagnóstico amplo das necessidades e emergências do bioma, que foram apresentadas publicamente no Seminário de Macapá. A metodologia do Seminário e do projeto pressupunha discutir com a sociedade civil os dados sistematizados sobre a situação da conservação da biodiversidade e da floresta amazônicas como também debater propostas de ações prioritárias para sua conservação. Durante o Seminário, inputs de diferentes perspectivas, vindas de setores 
diversos, foram agregados a esse esforço. As recomendações do Seminário de Macapá, dessa forma, tornaram-se referência para o trabalho do ISA.

De acordo com entrevistado (Entrevista 21, 2/4/2014), esse processo colocou a instituição em posição muito relevante em termos de discussão de políticas públicas, aproximando a ONG de diferentes atores governamentais e políticos. Após o resultado das eleições de 2002, o ISA tomou a iniciativa de organizar outro seminário em Brasília com a participação de diferentes organizações sociais de atuação na Amazônia, inclusive de sindicatos de trabalhadores rurais, para debater novamente as ações prioritárias para conservação do bioma e sistematizar contribuições para o novo governo. Com a realização desse seminário, a ONG assumia uma atitude ativa e propositiva diante do novo cenário político.

A instituição, em seu trabalho de advocacy em Brasília e em outros estados, desenvolveu uma relação fluida com a então senadora da república Marina Silva e com outros políticos do PT, o que a fazia crer que conseguiriam influenciar o novo governo com maior incisão. Com a nomeação de Capobianco para a Secretaria de Biodiversidade e Florestas, o projeto a ser implementado no MMA para o bioma amazônico estava rascunhado. Esse caso corrobora a defesa do argumento de que militantes de movimentos sociais carregam suas bandeiras, projetos e experiências para o interior do Estado quando são nomeados a assumirem cargos públicos. A partir desse momento, um modelo alternativo de política pública é gestado no MMA.

Capobianco é biólogo e, na ocasião de sua nomeação, era doutorando em agricultura e meio ambiente pela Universidade Estadual de Campinas. É ambientalista militante, fundador da Fundação SOS Mata Atlântica, da Rede de ONGs da Mata Atlântica e do Instituto Socioambiental, onde era coordenador do Programa Mata Atlântica e integrava seu conselho diretor quando foi nomeado para o MMA. Foi muito ativo em conselhos ambientais no estado de São Paulo e no Conselho Nacional de Meio Ambiente (Conama) e se destacava pelo conhecimento técnico sobre questões florestais e de conservação.

Para um dos secretários da gestão Marina Silva, três grupos diferentes compuseram o MMA em 2003: aqueles que vieram de ONGs; os que eram militantes ambientais no PT; e um grupo fiel à ministra que trabalhou mais diretamente em sua assessoria desde a experiência política no Acre e 
também no Senado Federal. Esse último grupo assumiu prioritariamente cargos de segundo escalão. Conforme narrou o secretário em questão, a composição do MMA "não era [de] gente que trabalhava com as mesmas pautas ou com as mesmas agendas” (Entrevista 12, 21/7/2014).

Marina nomeou Cláudio Langone, filiado ao Partido dos Trabalhadores, para o cargo de secretário-executivo do MMA. Langone, engenheiro químico e militante aguerrido do movimento estudantil, criou, estruturou e chefiou a Secretaria Estadual do Meio Ambiente do Rio Grande do Sul (Sema-RS) entre 1999 e 2002, durante o governo do PT no estado. Era presidente da Associação Brasileira de Entidades de Meio Ambiente (Abema) e nome conhecido do movimento ambiental.

Na cota do PT, ainda foram nomeados para o alto escalão Gilney Viana, para a Secretaria de Políticas para o Desenvolvimento Sustentável, e João Bosco Senra, para a Secretaria de Recursos Hídricos. Viana é médico epidemiologista, doutor na área de saúde e meio ambiente, político, um dos fundadores do PT nos estados do Mato Grosso e Minas Gerais, militante histórico da causa dentro do partido e nas legislaturas em que foi deputado. Junto a Marina Silva, ele estruturou e fortaleceu a Secretaria de Meio Ambiente e Desenvolvimento (Smad) do PT. Foi responsável pela área ambiental na transição do governo (2002-2003) e cotado para ser ministro do meio ambiente. Desenvolveu trabalho com movimentos sociais e ONGs no Mato Grosso. Senra, engenheiro civil e sanitarista, foi diretor-geral do Instituto Mineiro de Gestão da Água, Secretário de Meio Ambiente da prefeitura de Belo Horizonte (1993-1996) e Secretário de Meio Ambiente e Desenvolvimento do PT.

A Secretaria de Qualidade Ambiental e a Secretaria de Coordenação da Amazônia foram chefiadas, respectivamente, por Marijane Lisboa e Mary Allegretti. Lisboa vinha da ONG Greenpeace e contava com larga experiência profissional nos debates sobre transgênicos, resíduos sólidos e poluição. Assessorava Marina Silva em sua função legislativa no que se referia a esses temas. Mary Allegretti, que exercia a mesma função ministerial na gestão anterior, além de ter experiência em ONG, foi muito próxima de Chico Mendes e do Movimento dos Seringueiros no estado do Acre, muito caros à Marina Silva. 
É possível observar que o primeiro escalão do MMA foi composto por pessoas com cacife técnico e ou político e com experiência na área ambiental, mesmo aqueles que vinham do PT. Sua composição não se tratava de resultado de negociações para alcançar governabilidade no Congresso Nacional, mas refletia acordos construídos dentro da rede de atores importantes para aquele subsistema de política pública que se mostrava aberto para diferentes atores, dentre eles, representantes de movimentos sociais.

A Secretaria de Biodiversidade e Florestas (SBF), chefiada por Capobianco, comportava três diretorias. Capobianco nomeou para o cargo de diretor do Programa Nacional de Áreas Protegidas o servidor público Maurício Mercadante, engenheiro florestal com mestrado em ecologia, consultor legislativo para meio ambiente da Câmara dos Deputados e ex-funcionário da ONG Funatura. Mercadante era importante aliado dos ativistas ambientais na Câmara dos Deputados. A troca de informações técnicas e políticas beneficiava tanto o movimento quanto o servidor público no exercício de suas funções. Devido à sua experiência de trabalho com unidades de conservação, na Funatura, foi o principal protagonista na elaboração do Projeto que resultou na Lei do Sistema de Unidades de Conservação, a Lei do Snuc. Na Câmara dos Deputados, era seu defensor mais aguerrido. Paulo Kageyama, professor de engenharia florestal da Universidade de São Paulo, foi o diretor do Programa Nacional de Conservação da Biodiversidade. Apesar de ser acadêmico e de ter influência sobre muitos ambientalistas, Kageyama desenvolvia projetos com movimentos sociais e, enquanto acadêmico militante, contribuiu com o trabalho de definição de áreas prioritárias para a conservação na Amazônia, coordenado por Capobianco.

Carlos Vicente, engenheiro agrônomo com mestrado em economia, havia trabalhado em projetos com comunidades tradicionais no Acre e foi Secretário de Gestão de Florestas durante o primeiro governo petista (1999-2002) daquele estado, tendo proximidade com Marina Silva. No MMA, foi nomeado para o cargo de diretor do Programa Nacional de Florestas. Ao final de 2003, Vicente foi realocado para trabalhar no gabinete da ministra e Tasso Azevedo, que vinha da organização não governamental Instituto de Manejo e Certificação Florestal e Agrícola (Imaflora), assumiu sua função. A pauta de Azevedo para a proteção ambiental considerava principalmente estabelecer incentivos econômicos e certificações para o aproveitamento das florestas. Ele havia participado daquela reunião em dezembro de 2002 para pensar 
ações estratégicas para a política ambiental e se responsabilizou por elaborar ações na área florestal. O Departamento de Patrimônio Genético, vinculado à SBF, foi chefiado por Eduardo Velez Martin. Velez, à época, era mestre em ecologia e havia sido diretor do Museu de Ciências Naturais da Fundação Zoobotânica do Rio Grande do Sul (1999-2002).

A composição da diretoria da SBF em 2003 foi diversificada, com representantes da academia, de ONGs, e pessoas com experiência no governo estadual e federal (no poder Legislativo). Foi observado que os diretores eram comprometidos com causas e projetos que desenvolveram em suas experiências profissionais anteriores, o que sinaliza muito positivamente para uma composição baseada em referências profissionais e não apenas em acertos políticos (OLIVEIRA, 2016).

Em 2007, começo da segunda gestão do PT no governo federal, a Ministra empreendeu mudanças na estrutura organizacional do Ministério (MMA, 2007). Quatro novas secretarias foram criadas e ocorreu a divisão do Instituto Brasileiro de Meio Ambiente e Recursos Naturais (Ibama), quando as atribuições relativas à conservação das florestas foram repassadas para o recém-criado Instituto Chico Mendes de Biodiversidade (ICMBio). Foi criado ainda o Serviço Florestal Brasileiro (SFB).

Uma nova equipe assumiu cargos DAS, tanto na posição de secretários como de diretores. As alterações foram coordenadas principalmente por Capobianco, que de fato se tornou o braço direito da Ministra. Conforme informado por Gilney Viana ao site Repórter Brasil (THENÓRIO, 2007), a reestruturação refletiu a intenção política de fortalecer a estratégia de comando e controle do Ministério, que deu sustentação para a implementação do PPCDAm. Os três secretários do PT foram substituídos. Capobianco assumiu a Secretaria-Executiva. Na SBF, substituindo Capobianco, veio Maria Cecília Wey de Britto, engenheira agrônoma com importante experiência de trabalho no governo do estado de São Paulo, mesmo estado de onde veio Capobianco. Tasso Azevedo ficou responsável por dirigir o Serviço Florestal Brasileiro. O novo presidente do Ibama era Paulo Lacerda, ex-diretor-geral da Polícia Federal, o que sinalizava para a política de fiscalização, comando e controle a ser exercida pelo órgão, e o ICMBio foi presidido em caráter substitutivo por João Paulo Capobianco até a nomeação de Rômulo Mello para a presidência do instituto em 2008. 
Com a criação do Serviço Florestal Brasileiro, foram empenhados esforços para modernizar e tornar as florestas nacionais atraentes para o investimento do setor empresarial e promover o controle do uso da floresta no Brasil. Já para o desmembramento do Ibama, uma das razões apresentadas era fortalecer a área de licenciamento ambiental, desvinculando as funções que possuía em relação à gestão de áreas protegidas. Criar uma autarquia para gerenciar as áreas protegidas, para o MMA, era também uma forma de fortalecer institucionalmente essa função no governo (Entrevista 21, 2/4/2014). Essas ações foram pensadas também com o intuito de melhorar a implementação da principal política daquela gestão, o PPCDAm.

Ao analisar as trajetórias das pessoas que assumiram diretorias no MMA após a reestruturação, foram identificadas duas que possuíam ligação direta com Capobianco e/ou com ONGs em que o biólogo atuou antes de assumir cargos no governo, a saber: André Lima e Mauro Pires. Lima, advogado com experiência na área de florestas e desmatamento, foi nomeado para a Diretoria de Articulação de Ações da Amazônia, mas, por sua experiência profissional, passou para a Diretoria de Políticas para o Combate ao Desmatamento, vinculada à Secretaria-Executiva. Ele trabalhou com Capobianco na Fundação SOS Mata Atlântica e no ISA. As ações de combate ao desmatamento na Amazônia foram transferidas para a Secretaria-Executiva, sob a batuta de Capobianco. Afinal, esse projeto tinha um responsável claro.

A outra pessoa era Mauro Pires, que foi chefe de gabinete de Capobianco enquanto estava na SBF, mas na reestruturação assumiu diferentes diretorias de programa relacionadas ao bioma amazônico. Pires trabalhou no Instituto Sociedade, População e Natureza, foi articulador da Rede Cerrado de ONGs, consultor de projetos no MMA durante a gestão do PSDB e foi filiado ao PT. Apesar de diferentes experiências, construiu uma ligação forte com ONGs e seus representantes.

Na opinião da maioria dos entrevistados com algum tipo de vínculo ou experiência de articulação com o Ministério, Capobianco foi o secretário que mais se destacou nesse período e "foi o escolhido de Marina para se tornar o seu braço direito” (Entrevista 12, 21/7/2014). Esse espaço foi alcançado devido a uma confluência de intencionalidades e causalidades que foram importantes para desenvolver a política de maior destaque na história do MMA. As ações empreendidas naquele período para combater os níveis 
recordes de desmatamento na Amazônia foram assumidas e adaptadas pelos gestores que vieram para o MMA após a administração de Marina Silva, e, com algumas variações ao longo dos anos, conseguiram manter a taxa de desmatamento baixa, conforme será mostrado adiante. No rastro do relativo sucesso dessa política, outras ações na área de biodiversidade e florestas puderam ser desenvolvidas e elevaram a SBF ao posto de uma secretaria importante, perfil oposto ao que tinha em outras administrações do MMA anteriores a 2003 (Entrevista 24, 26/5/2015; Entrevista 27, 4/11/2013).

A formação da equipe ministerial pareceu refletir a dinâmica de uma rede de atores interconectados em torno de trajetórias e da defesa de agendas em comum e sugere estar baseada mais na militância e relevância de propostas defendidas do que na filiação institucional. O subsistema da política ambiental apresentava características que facilitavam uma ação coordenada entre atores de diferentes campos e setores - movimentos sociais, academia, partidos políticos, Estado - e isso foi importante para que ambientalistas acessassem o Estado. A liderança exercida por Marina Silva teve papel significativo pois seu projeto, carisma e compromisso com a pauta ambiental congregava diferentes grupos ao seu redor.

Outro elemento fundamental a ser considerado é a capacidade e conhecimento técnicos de Capobianco e da equipe que formou no MMA. Capobianco era uma das principais referências do tema florestal na sociedade civil, mas ele não era o único. Conforme exposto em entrevista anteriormente citada, o conhecimento técnico sobre a questão ambiental se encontrava principalmente na sociedade e não na burocracia do Estado ou nos partidos políticos. Com isso, é possível assumir que o movimento ambientalista possuía características que o cacifavam no debate político e de políticas públicas ambientais. Nesse sentido, conclui-se que os ambientalistas assumiram cargos no MMA devido à capacidade técnica destacada - o que importa tanto para a lógica de ocupação de cargos públicos como para a análise das características de movimentos sociais que ocupam esses cargos -, num subsistema de política pública que coordena a influência de atores de diferentes trajetórias dentro de um regime político aberto para movimentos sociais. Isso favoreceu o desenho e a implementação do PPCDAm. 


\section{Plano de Prevenção e Combate ao Desmatamento na} Amazônia (PPCDAM)

Em junho de 2003, o Instituto Nacional de Pesquisas Espaciais (Inpe) publicou dados relativos ao desmatamento na Amazônia ocorrido no período anual 2001-2002. O relatório indicava um aumento de 40\% no desmatamento em relação ao período anterior e sinalizava para o agravamento da situação no período seguinte, uma vez que o aumento havia acontecido em momento de contração econômica (BRASIL, 2004). Caso houvesse uma aceleração da economia, o impacto no desflorestamento poderia ser muito pior. ${ }^{7} \mathrm{O}$ MMA, a fim de fazer um diagnóstico cuidadoso das causas do desmatamento, buscou uma articulação com órgãos do governo federal e com a Casa Civil da Presidência da República. Em 3 de julho do mesmo ano, foi publicado o decreto presidencial sem número que estabeleceu um Grupo de Trabalho Interministerial (GTI) com a finalidade de propor medidas e coordenar ações que visassem a redução dos níveis de desmatamento na Amazônia (BRASIL, 2004).

Antes da criação do GTI, a Secretaria de Biodiversidade e Florestas, coordenada por Capobianco, havia realizado um seminário para análise dos dados do desmatamento, do qual participaram cientistas de distintas áreas e oito representantes da sociedade civil que trabalhavam com o tema. Durante o seminário foram qualificados os dados do desmatamento, especialmente no que se referia à sua espacialização e estabelecimento de correlações com atividades produtivas, políticas públicas e forças sociais, econômicas e políticas da região (BRASIL, 2004, p. 8). O MMA, junto ao Ibama, havia iniciado também a elaboração do Plano de Ação para a Prevenção e Controle do Desmatamento, Queimadas e Exploração Madeireira Ilegal (Padeq), envolvendo a participação de outros ministérios e também organizações da sociedade civil. O Padeq serviu como subsídio para a elaboração do Plano de Ação para Prevenção e Combate ao Desmatamento da Amazônia Legal (PPCDAm), lançado em março de 2004.

7 Em 2003, a taxa de desmatamento foi de $25.386 \mathrm{~km}^{2}$ e em 2004 aumentou para $27.772 \mathrm{~km}^{2}$, a maior desde 1995, que registrou um desmatamento recorde de $29.059 \mathrm{~km}^{2}$ (BRASIL, 2004). 
A ação de combate ao desmatamento foi coordenada, com demasiado envolvimento, por Capobianco. De acordo com um dirigente da SBF à época foi feito, na área de biodiversidade e florestas, um planejamento muito bem detalhado, com etapas definidas e estratégias claras, e isso deu à equipe da Secretaria capacidade de dialogar com o governo de maneira mais assertiva. A realização desse planejamento foi possível devido aos resultados do Projeto de Avaliação e Identificação de Ações Prioritárias para Conservação, Utilização Sustentável e Repartição dos Benefícios da Biodiversidade da Amazônia Brasileira, coordenado por Capobianco enquanto era funcionário do ISA, e sistematizado no Seminário de Macapá em 2000 (Entrevista 21, 2/4/2014). De acordo com Bensusan (2006, p. 8), o Seminário produziu resultados significativos:

Sete mapas regionais foram produzidos e 379 áreas foram definidas como prioritárias. Para cada uma dessas áreas prioritárias, foi elaborada uma ficha com informações sobre localização; principais características; grau de importância biológica por grupo temático; grau de importância em temas de serviços ambientais; grau de estabilidade (inserção de unidades de conservação ou terras indígenas); grau de instabilidade [...]. Também foram arroladas ações prioritárias relativas às unidades de conservação de uso indireto e uso direto; às populações tradicionais; ao uso econômico de áreas alteradas; às terras indígenas, aos polos de desenvolvimento; e à pesquisa científica. Os resultados desse seminário de consulta são o principal subsídio para a identificação de novas áreas de conservação e para nortear políticas de proteção e uso sustentável da biodiversidade no Brasil.

Esse quadro demonstra o quão bem informados e direcionados estavam Capobianco e sua equipe. A elaboração do PPCDAm, com a coordenação da Casa Civil, foi resultado desse direcionamento que a SBF tinha em suas ações e pela situação emergencial que trazia a ameaça de aumento ainda mais crítico no desflorestamento amazônico. Conforme narram dirigentes do Ministério, uma conjunção de fatores foi fundamental: 
Eu tenho a impressão de que isso [agenda de trabalho definida] não acontecia nas outras áreas do governo. Nós construímos isso. Pega o caso do desmatamento da Amazônia. Nós começamos de pouco, do comecinho, como tornar público os dados do Inpe. ${ }^{8}$ Depois, criar um GTI em que no decreto estivesse claro que o grupo estava organizado para reduzir o desmatamento na Amazônia, e isso saiu em decreto. O plano de desmatamento que foi organizado em tempo recorde e o presidente lançou esse plano. Garantimos que o plano fosse coordenado pela Casa Civil e não por nós que éramos mais fracos. Isso em função da ação e persistência da Marina. Ela fez o governo avançar de forma impressionante. Então, ela confiava na equipe dela, ela tinha boa interlocução com o governo e ela fazia disso uma batalha permanente. (Entrevista 21, 2/4/2014).

Na agenda do desmatamento, tem dois elementos aí, a Casa Civil coordenava, mas tinha no Capô[bianco] uma liderança que fazia tudo acontecer. Então era assim: o Capô usava a legitimidade da Casa Civil, mas quem pressionava era ele, com o aval da Marina, que tinha acesso direto ao Lula também. E, no começo, ao Zé Dirceu [Dirceu era ministro da Casa Civil à época]. A Marina tinha um acesso muito bom ao Zé Dirceu. Ele dava carta branca pra Marina. Ele conduziu [o plano] durante dois anos e Marina tinha bom acesso a ele e ao Lula. E o Capô aproveitou isso também e fez a coisa rodar e a gente tinha naquele período altas taxas de desmatamento [...]. (Entrevista 4, 8/4/2013).

Os depoimentos anteriormente citados revelam uma confluência de fatores do contexto político e um trabalho de militância e agência de Marina Silva e Capobianco que contribuíram para o desenvolvimento da agenda de combate ao desmatamento. O ponto inicial é, de fato, o preparo da equipe

8 Em 2004 foi criado o Sistema de Detecção do Desmatamento em Tempo Real (Deter) do Inpe. Esse sistema produz alertas diários de desmatamento aos órgãos de controle e fiscalização e também disponibiliza ao público geral relatórios elaborados mensal ou bimestralmente. Para o Ibama, os relatórios são diários. 
da SBF em diagnosticar e projetar ações para combater tal situação crítica, viabilizado pelo trabalho realizado previamente por atores da sociedade civil que levaram seu conhecimento para a burocracia estatal. O apoio de Marina Silva à causa que lhe era bastante cara - uma vez que a Ministra já revelara que sua prioridade era a Amazônia - cacifou politicamente o projeto até então técnico. O suporte alcançado com o núcleo político do PT no governo abriu as portas para, no início do mandato, definir uma ação interministerial importante, envolvendo órgãos de diferentes áreas no apoio à agenda emergencial. Por fim, o perfil de liderança de Capobianco e Marina Silva, juntos, “fazendo as coisas acontecerem” era determinante.

O GTI de combate ao desmatamento foi coordenado politicamente pela Casa Civil e tecnicamente pelo MMA, e foi composto por representantes de 13 Ministérios, envolvendo diferentes áreas do governo. Como primeiro passo, foram estabelecidos quatro subgrupos de trabalho para a elaboração de propostas estratégicas, a saber: $i$ ) ordenamento fundiário e territorial, coordenado pela SDS/MMA; ii) monitoramento e controle, coordenado pelo Ibama/MMA; iii) fomento a atividades produtivas sustentáveis, coordenado pelo SBF/MMA; e iv) infraestrutura, coordenado pela Secretaria de Coordenação da Amazônia (SCA/MMA). Esses se tornariam os eixos de trabalho do PPCDAm.

Na primeira fase de implementação do plano, de 2004 a 2008, ${ }^{9}$ o eixo ordenamento fundiário e territorial logrou êxito com a criação de mais de 25 milhões de hectares de unidades de conservação federais e a homologação de 10 milhões de hectares de terras indígenas. Os estados também empenharam esforços para a criação de áreas protegidas. Esse eixo estava sob a coordenação da Secretaria de Desenvolvimento Sustentável (SDS), mas a secretaria responsável pela consolidação do sucesso da primeira fase do PPCDAm foi exatamente a SBF com a estratégia de criar grandes hectares de unidades de conservação. Para Gilney Viana, em entrevista ao Repórter Brasil, a gestão de Marina Silva optou por um viés conservacionista e não

9 Na segunda fase, que se estendeu de 2009 a 2011, o eixo monitoramento e controle foi o responsável pela queda do desmatamento e, na terceira fase, de 2012 a 2015, seria desenvolvido o eixo fomento a atividades produtivas. Foi desenhada uma quarta fase que abordará instrumentos econômicos e terminará em 2020. 
houve espaço para a implementação dos instrumentos econômicos que Viana e sua SDS prezavam. Marina dava sinais de identificação prática, simbólica e política com um grupo específico no MMA.

A ação da equipe ambiental contribuiu para a queda vertiginosa da taxa de desmatamento ao longo dos anos. A exceção foi em 2008, quando a área desmatada voltou a crescer, mas recuperou a margem decrescente já no ano seguinte. De acordo com dados do gráfico a seguir, a taxa caiu de 22.772 $\mathrm{km}^{2}$, em 2004, para $4.848 \mathrm{~km}^{2}$, em 2014, constatando o sucesso da política. Em 10 anos, a área de floresta desmatada na Amazônia foi reduzida em 82,5\%. Esses dados posicionaram o Brasil em alto patamar nas discussões internacionais sobre mudanças climáticas e colocaram o país mais próximo do cumprimento da meta voluntária estabelecida pela Política Nacional sobre Mudança do Clima, que é de 36\% a 39\% em relação ao projetado para 2020. ${ }^{10}$

Gráfico 1: Taxas de desmatamento na Amazônia Legal medidas por meio do Prodes (Projeto de Monitoramento do Desflorestamento na Amazônia Legal), Inpe/MCTI

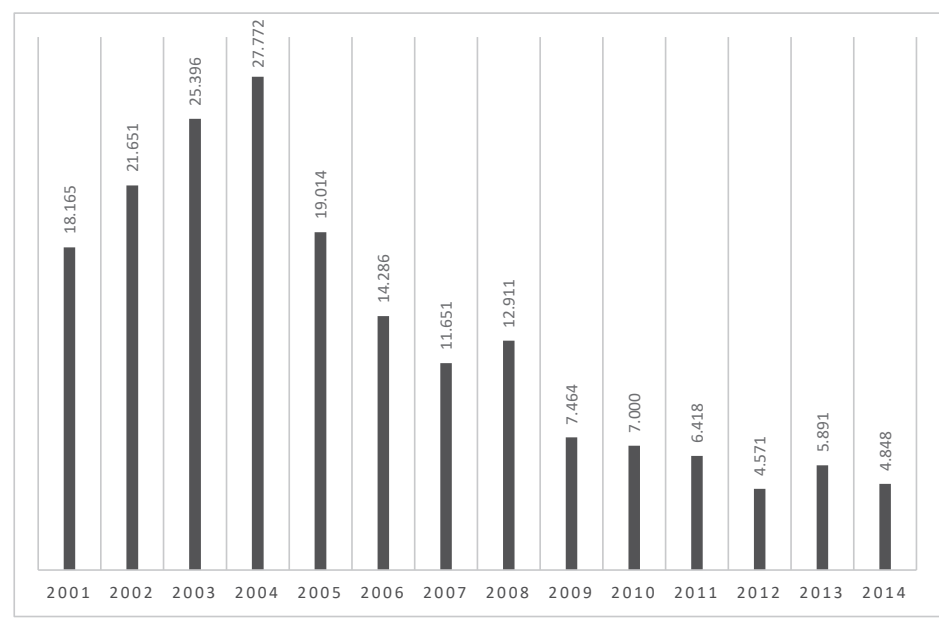

10 “Segundo o Decreto n 7.390/2010, que regulamenta a Política Nacional sobre Mudança do Clima, a linha de base de emissões de gases de efeito estufa para 2020 foi estimada em 3,236 GtCO2-eq. Assim, a redução absoluta correspondente ficou estabelecida entre 1,168 GtCO2-eq e 1,259 GtCO2-eq, 36,1\% e 38,9\% de redução de emissões, respectivamente.” (MMA, s.d.). 
O episódio de alta do desmatamento para 2008 já era esperado. Em julho de 2007, pouco antes do Inpe revelar os dados de desmatamento do período anterior (2005-2006), André Lima - que vinha do ISA e foi nomeado diretor do Departamento de Articulação de Ações da Amazônia, alocado na Secretaria-Executiva, para onde Capobianco havia migrado com a reforma ministerial - fez uma avaliação dos dados do desmatamento e concluiu que esse iria aumentar principalmente pelos seguintes motivos: aumento do preço de commodity agrícola, aumento do processo de grilagem e eleição municipal no ano seguinte. ${ }^{11}$ A estratégia de colocar o Ibama e a Polícia Federal na rua, fiscalizando e controlando, não funcionaria para aquele ano pois essa ação não estava mais sendo efetiva. Foi chamada, por isso, uma reunião de emergência com a presença de Dilma Rousseff, a então ministra da Casa Civil, e de ministros de outras áreas, como o do Ministério da Agricultura e Pecuária (Mapa).

Lima foi realocado no Departamento de Políticas para o Combate ao Desmatamento - também da Secretaria-Executiva do MMA - e em três meses preparou um pacote de ações a serem implementadas pelo governo. ${ }^{12}$ Em dezembro de 2007, o presidente Luiz Inácio Lula da Silva publicou o decreto 6.321, que dispunha sobre ações relativas à prevenção, monitoramento e controle do desmatamento na Amazônia e previa que o MMA editaria anualmente portaria com lista de municípios que desmataram na Amazônia, a "Lista Negra dos Municípios”.

Esse decreto foi acompanhado de resoluções do Instituto de Colonização e Reforma Agrária (INCRA) e do Banco Central que determinavam corte de crédito rural para os municípios da Lista Negra. Havia, ainda,

${ }^{11} \mathrm{O}$ ex-Ministro de Meio Ambiente, Carlos Minc, no período em que exercia o cargo (2008-2010), informou que, em momentos de eleições municipais, o desmatamento tende a aumentar em função da hesitação de governadores em aplicar multas e embargar terras para não gerar suscetibilidades políticas. O MMA publicou dados do desmatamento que confirmam a informação fornecida pelo ex-Ministro (PIRES, 2008).

${ }^{12} \mathrm{O}$ tripé da agenda de combate ao desmatamento era estruturado pelos dirigentes do Departamento de Políticas para o Combate ao Desmatamento/MMA (André Lima), do Serviço Florestal Brasileira (Tasso Azevedo) e da Diretoria de Áreas Protegidas do Ibama (Flávio Montiel). Todos vindos de ONGs. 
corresponsabilidade para as empresas que comprassem commodities de origem ilegal. Em abril de 2008, todas as normas estavam publicadas e, em 2009, conforme observado no gráfico 1 , o índice de desmatamento voltou a cair. Em termos de políticas públicas, o decreto foi bastante efetivo, mas no que se refere ao jogo político, foi prejudicial ao PT, conforme narra entrevistado:

[...] a gente conseguiu o resultado que queria que batia de frente com os interesses da Amazônia. Quem estava pagando campanha eleitoral na Amazônia? O desmatamento, é ele que pagou a campanha eleitoral de 2008. Com aquela pesquisa que a gente fez da lista dos municípios críticos, o PT perdeu eleição em municípios que a gente colocou como desmatadores. Isso gerou pressão em cima dos governadores. Tem município do MT que perdeu investimento. Teve indústria que ia implementar uma planta de alimentos, mas deixou de implementar porque o município estava na Lista Negra. Teve impacto forte na área econômica: 4 bilhões de reais de crédito que deixaram de ir para a Amazônia, para a pecuária. Então, nós mexemos pra valer. Os governadores ficaram furiosos porque teve uma intervenção forte. (Entrevista 4, 8/4/2013).

Outro entrevistado, também dirigente do MMA, faz relação direta desse evento político com a saída da Marina Silva do MMA, a ver:

Nós sempre fomos solidários com o governo, mas sempre na perspectiva nossa institucional. Isso não é muito comum, pois os Ministérios tentam agradar ao Palácio [do Planalto] com soluções rápidas para casos complicados e nós não éramos assim. Agora, quando isso mudou e nos fez sair do governo? Foi quando percebemos que haveria um retrocesso na agenda. Pois apesar de você ter dificuldades para avançar a agenda, para nós, estava valendo. Mas, no momento que percebemos que haveria um retrocesso - e esse retrocesso foi anunciado pelo presidente Lula, numa reunião com governadores da Amazônia, em que o Lula disse publicamente, respondendo ao Maggi, que mudaria o decreto de dezembro de 2007 que estabeleceu rigor enorme ao controle do desmatamento e também decidiu transferir o 
PAS [Programa Amazônia Sustentável] para a SAE [Secretaria de Assuntos Estratégicos] - naquele momento, pela primeira vez, ficou claro que haveria um retrocesso. Ele não deu chance para Marina, ele não negociou o decreto, ele anunciou publicamente que mudaria o decreto. Nós decidimos que não dava mais para ficar. A saída do governo, para nós, foi a forma que utilizamos para que ele não alterasse o decreto. Se saíssemos antes que ele alterasse o decreto, nós poderíamos conseguir o que queríamos. Se saíssemos depois, seria um fracasso. (Entrevista 21, 2/4/2014).

A primeira dessas duas narrativas expõe uma condição sine qua non para os partidos políticos: a importância do mercado eleitoral e a conquista de votos. O que os entrevistados revelam é que o governo estava disposto a sacrificar uma política pública eficaz para rever as perdas eleitorais que aconteceram em função do acirramento das normas de combate ao desmatamento na Amazônia. Essa política era o foco de atenção e de luta de Marina Silva e era o resultado de uma agenda que vinha da sociedade civil: uma política pública implementada por ambientalistas que confrontava diretamente a agenda da agricultura patronal, dentre outras pautas do governo, e se opunha aos interesses de empresários ruralistas.

Com a mudança de perspectiva do governo para atender ao agronegócio, Marina apresentou sua carta de exoneração do cargo de ministra em 13 de maio de 2008. Para um dirigente do MMA, ocorreu um processo de perda de legitimidade dentro do governo (Entrevista 4, 8/4/2013). Naquele período, a chanceler alemã Angela Merkel estava de visita ao Brasil e, perguntada sobre a saída de Marina Silva do governo, fez votos para que o presidente não mudasse a orientação ambiental. Os ambientalistas creditam a esse fato político a desistência do presidente de mudar o decreto, que permaneceu como estava e se tornou uma diretriz central (Entrevista 21, 2/4/2014).

Fato curioso no depoimento anteriormente citado é que o entrevistado, que formava o grupo de apoio, de defesa de projetos e de trajetória em comum com Marina Silva, colocou que eles eram solidários ao governo, mas que seguiam orientações próprias em suas funções no MMA, revelando certa independência do resto do governo. Ele complementou: 
Nossa permanência no MMA foi sempre avaliada numa perspectiva de custo benefício. Em vários momentos, tivemos crises, como a dos transgênicos. Em vários momentos, nós avaliamos as dificuldades e as possibilidades de avançar com a agenda socioambiental. [...] não houve nenhum caso que deixamos de lado um aspecto relevante para atender ao Palácio. Isso, obviamente, cria um desconforto. Vinha a pergunta: vocês são ou não do governo? Nós somos do governo, mas fazemos o procedimento certo [...] (Entrevista 21, 2/4/2014).

Tal situação vinha criando desgastes à permanência de Marina Silva e sua equipe no governo do PT. Representantes do partido revelaram que esse comportamento os afastou da gestão da ministra, tanto em termos de participação no seu ministério como em relação a apoio político (Entrevista 38, 5/6/2014; Entrevista 18, 28/11/2013). Com isso, a ministra se tornava mais livre para se associar a grupos da sociedade civil, mas se desgastava com seu partido. No segundo mandato do presidente Lula, que começou em 2007, Marina Silva foi a última ministra a ser anunciada. Na primeira gestão, ela fora a segunda.

Durante os cinco anos que coordenaram o MMA, Marina Silva e seu grupo alcançaram larga aprovação das ONGs ambientalistas. Conforme relataram entrevistados, essa gestão implementou o projeto da sociedade civil (Entrevista 5, 13/1/2015; Entrevista 30, 26/5/2015). Outro entrevistado revelou que, "já no primeiro ano, o sucesso do Plano de Prevenção e Combate ao Desmatamento deu um resultado tão forte para o governo que isso alavancou nossa credibilidade e a capacidade de trabalhar, e nós usamos esse cacife para alavancar várias áreas do governo” (Entrevista 21, 2/4/2014). Mas também houve críticas à gestão, como nos casos sobre os transgênicos e o licenciamento do Rio Madeira. ${ }^{13}$ Outras duas agendas importantes avançaram durante o período, em função do PPCDAm: a lei de gestão de florestas públicas e a estruturação da carreira burocrática de analista ambiental. Essa situação evidenciava a competência técnica e política de duas figuras extremamente ativas na área ambiental e da equipe que formaram.

${ }^{13}$ Para mais informações sobre esses casos, ver Oliveira (2016). 


\section{Considerações finais}

A nomeação de Marina Silva para chefiar a pasta ambiental do governo do Partido dos Trabalhadores configurou uma oportunidade importante para que lideranças do movimento ambientalista ocupassem posições políticas de destaque no MMA e implementassem uma agenda compatível com o projeto que defendiam na sociedade civil. Isso aponta para um regime político aberto à influência de movimentos sociais. A ministra, por sua vez, construiu reputação política e social, em nível nacional e internacional, tão positiva e importante que pesava a seu favor nas negociações necessárias com o núcleo do governo, o que lhe possibilitou também certa autonomia em relação à composição de seu ministério e às diretrizes governamentais a serem implementadas.

A equipe formada pela ministra - com trajetória compatível com seus ideais e com competência técnica das mais elogiosas - favoreceu a articulação técnica e política para o êxito da política de combate ao desmatamento na Amazônia. A liderança de Marina Silva e de Capobianco, pensando e articulando o plano, e a capacidade técnica da equipe no segundo escalão, como a ação estratégica de André Lima e os conhecimentos de Maurício Mercadante, foram essenciais para fazer o PPCDAm acontecer e obter sucesso em seus propósitos. A equipe responsável pelo desenho e condução do plano entre 2004 e 2007, tanto em nível de alto e médio escalão quanto da elite dirigente, foi prioritariamente formada por um perfil militante, de pessoas que acumularam experiências em organizações da sociedade civil, mas também com experiências no corpo estatal. Com isso, se observa que a variação de perfil do dirigente público pode ser benéfica à implementação de políticas públicas, especialmente se a expertise só é encontrada na sociedade. O subsistema da política ambiental funciona com a inclusão de atores de diferentes setores, numa ação em rede que vincula agentes de campo social e político.

A ocupação de cargos públicos por militantes de movimentos sociais possibilitou o desenho e a implementação de uma política inovadora e extremamente eficiente para os padrões da política ambiental brasileira. Essa política pública, o PPCDAm, é o resultado do acúmulo de experiências profissionais desses atores e de sua concepção de mundo, tanto que, quando ela foi ameaçada, aqueles por ela responsáveis preferiram não mais 
fazer parte do governo. É uma política que bate diretamente de frente com interesses econômicos, de caráter confrontacional marcante.

Para obter sucesso em sua implementação, foi necessária articulação entre capacidade técnica - característica marcante dos movimentos sociais no caso apresentado, especialmente de Capobianco - e política, garantida pela experiência de Marina Silva. Tudo isso ocorreu num regime político que se mostrava favorável à ação dos movimentos sociais, no qual o subsistema da política ambiental incluía atores de diferentes setores, e pela capacidade técnica e de articulação vinda dos movimentos sociais. Para o caso apresentado, conhecer o perfil dos ocupantes de cargos públicos foi crucial para entender o sucesso da política pública mais significativa da área ambiental no Brasil.

\section{Referências}

ABERS, Rebecca Neaera et al. Repertórios de interação estado-sociedade em um estado heterogêneo: a experiência na era Lula. Dados - Revista de Ciências Sociais, Rio de Janeiro, v. 57, n. 2, p. 325-357, 2014.

ABERS, Rebecca Neaera; OLIVEIRA, Marília Silva de. Nomeações políticas no Ministério do Meio Ambiente (2003-2013): interconexões entre ONGs, partidos e governos. Revista Opinião Pública, v. 21, n. 2, p. 336-364, 2015.

BENSUSAN, Nurit. Conservação da biodiversidade em áreas protegidas. Rio de Janeiro: Editora Fundação Getúlio Vargas, v. 1, 2006.

BRASIL. Ministério do Meio Ambiente. Plano de Ação para Prevenção e Controle do Desmatamento da Amazônia Legal. Brasília: Casa Civil, 2004. DIANI, Mario. The concept of social movement. The Sociological Review, v. 40, n. 1, p. 1-25, 1992.

DIANI, Mario; BISON, Ivano. Organizações, coalizões e movimentos. Revista Brasileira de Ciência Política, Brasília, n. 3, p. 219-250, 2010. 
D’ARAÚJO, Maria Celina. A elite dirigente do governo Lula: participação de Camila Lameirão. Rio de janeiro: CPDOC, 2009.

GEDDES, Barbara. Building 'state' autonomy in Brazil, 1930-1964. Comparative Politics, New York, v. 22, n. 2, p. 217-235, 1990.

HOCHSTETLER, Kathryn; KECK, Margareth. Greening Brazil: environmental activism in state and society. Durham: Duke University Press, 2007. LOPEZ, Félix Garcia. Cargos de confiança no presidencialismo de coalizão brasileiro. Brasília: Ipea, 2015. Volume 1.

LOPEZ, Félix Garcia et al. Partidos, facções e a ocupação de cargos de confiança no executivo federal (1999-2011). GT 3 Estudos legislativos: avanços e perspectivas. In: ENCONTRO ANUAL DA ANPOCS, 37., 2013. Anais [...] Águas de Lindóia/SP: ANPOCS, 2013.

LOPEZ, Félix Garcia; PRAÇA, Sérgio. Cargos de Confiança, partidos políticos e burocracia federal. Revista Iberoamericana de Estudos Legislativos, v. 4, p. 33-42, 2015 a.

LOPEZ, Félix Garcia; PRAÇA, Sérgio. Como são nomeados cargos de confiança no governo federal. In: BASSOTTI, Ivani Maria et al. (org.). Uma nova gestão é possível. São Paulo: FUNDAP, v. 1, $2015 \mathrm{~b}$.

LOUREIRO, Maria Rita; ABRÚCIO, Fernando Luiz; PACHECO, Regina Silvia. Burocracia e política no Brasil: desafios para a ordem democrática no século XXI. Rio de Janeiro: Editora FGV, 2010.

MARQUES, Eduardo César. Redes sociais e poder no Estado brasileiro: aprendizado a partir das políticas urbanas. Revista Brasileira de Ciências Sociais, v. 21, n. 60, p. 15-41, 2006.

MELUCCI, Antonio. Challenging codes: collective action in the information age. Nova York: Cambridge University Press, 1996. 
MMA. Reestruturação do MMA define com clareza competências de cada secretaria. 26/04/2007. Disponível em http://www.mma.gov.br/informma/ item/4061-reestruturacao-do-mma-define-com-clareza-competencias-decada-secretaria. Acesso em 08 ago. 2015.

MMA. Política Nacional sobre Mudança do Clima, s.d. Disponível em http://www.mma.gov.br/clima/politica-nacional-sobre-mudanca-do-clima). Acesso em 05 set. 2015.OLIVEIRA, Marília Silva de. Movimento para as instituições: movimento ambiental, partidos políticos e a liderança de Marina Silva. 2016. 303 f., il. Tese (Doutorado em Ciência Política) - Instituto de Ciência Política, Universidade de Brasília, Brasília, 2016.

PIRES, Carol. Eleições contribuem para aumento do desmatamento, diz Minc. Último Segundo. 29/09/2008. Disponível em: https://ultimosegundo. ig.com.br/brasil/eleicoes-contribuem-para-aumento-do-desmatamentodiz-minc/n1237690088412.html. Acesso em 05 set. 2015.RAILE, Eric; PEREIRA, Carlos; POWER, Timothy. The executive toolbox: building legislative support in a multiparty presidential regime. Political Research Quarterly, Utah, v. 64, n. 2, p. 323-334, 2011.

SCHNEIDER, Ben Ross. Burocracia pública e política industrial no Brasil. São Paulo: Editora Sumaré, 1994.

TATAGIBA, Luciana Ferreira; ABERS, Rebecca Neaera; SILVA, Marcelo Kunrath. Movimentos sociais e políticas públicas: ideias e experiências na construção de modelos alternativos. In: PIRES, Roberto; LOTTA, Gabriela S.; OLIVEIRA, Vanessa Elias de (org.). Burocracia e políticas públicas no Brasil: interseções analíticas. Brasília: Ipea/Enap, 2018.

THENÓRIO, Iberê. Restruturação do MMA prioriza comando e controle, avalia ex-secretário. Repórter Brasil, 27/04/2007. Disponível em http:// reporterbrasil.org.br/2007/04/restruturacao-do-mma-prioriza-comando-econtrole-avalia-ex-secretario/. Acesso em 08 ago. 2015. 


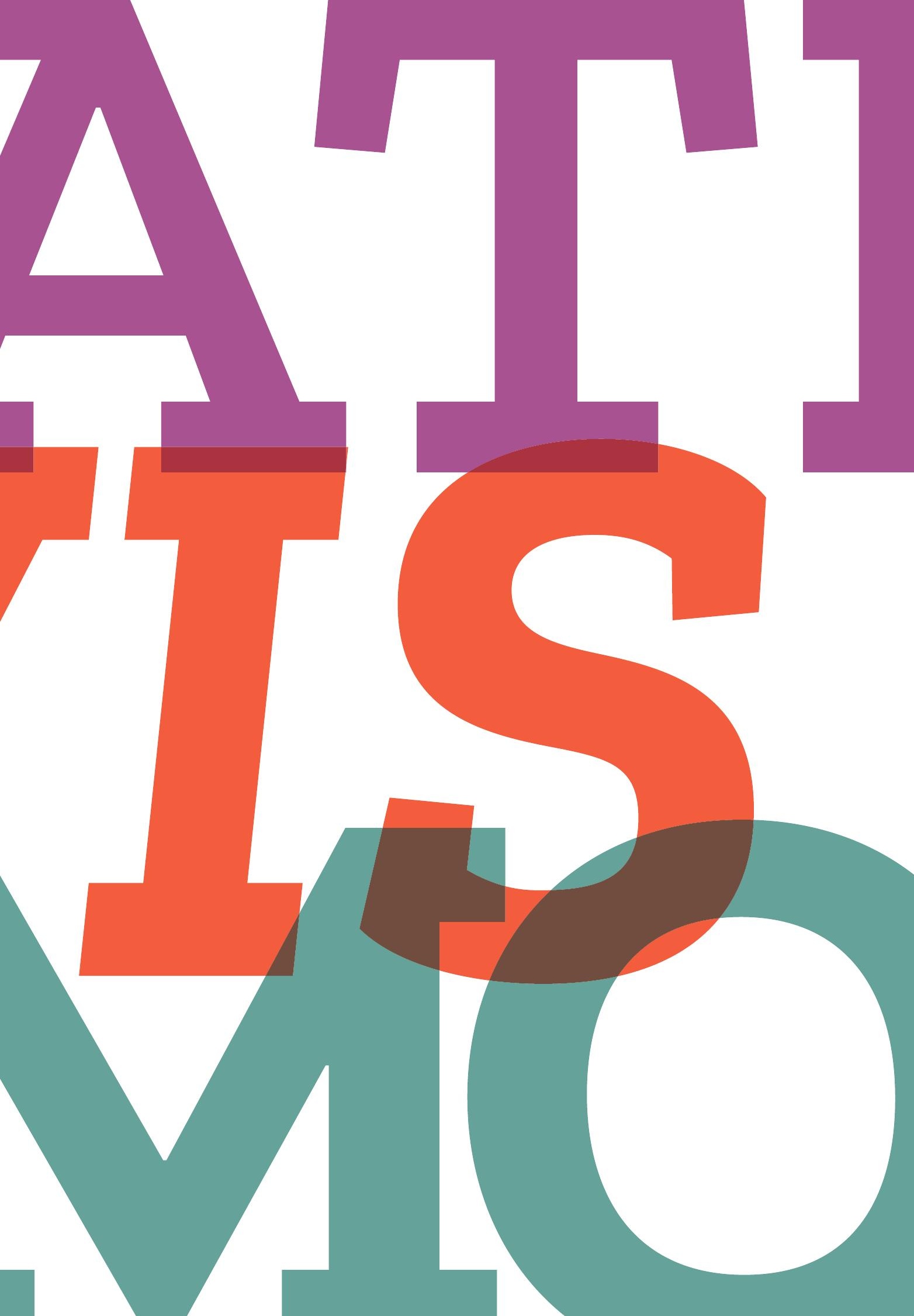




\section{Capítulo 4}

\section{Para além do gabinete: \\ $\mathrm{o}$ ativismo de procuradores no caso da Usina de Belo Monte ${ }^{1}$}

Luiz Henrique Vilaça

\section{Introdução}

Existe uma crescente preocupação em torno de ativistas que operam dentro de instituições (BANASZAK, 2010; PETTINICCHIO, 2012; ABERS, no prelo). Apesar de diversos estudos sobre os efeitos que esses ativistas têm em políticas públicas (RICH, 2013; ABERS; TATAGIBA, 2015; HYSING; OLSSON, 2017), os processos por meio dos quais burocratas se tornam ativistas foram pouco estudados. Neste capítulo, exploro

1 Agradeço os comentários e conselhos de Rebecca Abers, Marisa von Bülow, Carla Teixeira, Erin McDonnell, Terry McDonnell, Ann Mische, Rory McVeigh, Débora Rezende, Luciana Tatagiba e membros do grupo Repensando as Relações entre Sociedade e Estado (Resocie) e do grupo Studies in Politics and Movements. 
esse problema a partir de um estudo de caso sobre procuradores do Ministério Público Federal (MPF) no processo de formulação e implementação da usina hidrelétrica de Belo Monte (BM).

O Ministério Público (MP) é uma instituição intrigante. De apêndice do Poder Executivo e advogado do Estado, o órgão se tornou, no final do último século, independente - um “quarto poder” do Estado - e responsável pela defesa de interesses de grupos sociais diversos (COSLOVSKY, 2009). Procuradores se envolvem constantemente em disputas políticas, sendo chamados inclusive de "agentes políticos da lei” (ARANTES, 2002); no entanto, eles são incentivados a se comportarem de maneira cautelosa e a esconderem motivações políticas (COSLOVSKY, 2009). Além disso, grande parte deles (49\%) prioriza o trabalho mais tradicionalmente entendido como o papel do MP (investigações criminais), enquanto apenas 4\% dá prioridade para a defesa de minorias étnicas (LEMGRUBER et al., 2016). Neste trabalho, investigo a atuação de procuradores em conflitos étnicos e ambientais no caso da usina de Belo Monte (2001-2016).

A usina hidrelétrica de $\mathrm{BM}^{2}$ - localizada no rio Xingu, próximo à cidade de Altamira, no Pará - emergiu na agenda de agências estatais no Brasil na década de 1970 frente ao aumento do preço do petróleo no mercado internacional (DÓRIA, 1976). Desde o princípio, Belo Monte (que na época tinha o nome de Kararaô) foi extremamente contestada por atores diversos - como povos indígenas, organizações de movimentos sociais (OMS) e membros da comunidade acadêmica - devido aos possíveis impactos no ecossistema e nas comunidades locais (MAGALHÃES; HERNANDEZ, 2009). A mobilização intensa em torno da hidrelétrica - que culminou com um grande protesto em 1989, o $1^{\circ}$ Encontro das Nações Indígenas do Xingu - acabou levando o Banco Mundial, então financiador do projeto, a recuar, deixando os planos para a construção de Belo

2 Belo Monte foi apresentada como uma das três maiores hidrelétricas do mundo em termos de potência instalada, com 11.233 Megawatts (MW). Não há consenso, no entanto, em torno da capacidade efetiva da usina, uma vez que, devido à redução do reservatório em alguns períodos do ano, a capacidade instalada só seria "alcançada apenas por três meses no ano” (PEREIRA, 2014, p. 126). De acordo com Bermann (2012, p. 8), a capacidade média da usina deve girar em torno de 4.428 MW por ano. 
Monte engavetados por alguns anos (PEREIRA, 2014, p. 121). Durante a década de 1990, novos estudos foram realizados e um projeto revisado foi apresentado pela Eletronorte (BERMANN, 2012). A partir de então, Belo Monte passou a ganhar um lugar importante na agenda de diversas instituições estatais e foi aprovada no Congresso Nacional em 2005, teve seu licenciamento ambiental iniciado no ano seguinte e seus direitos de construção arrematados pelo consórcio Norte Energia ${ }^{3}$ em 2010. Ainda em meio a protestos, a usina foi inaugurada em $2015 .{ }^{4}$

O MPF começou a se envolver no caso em 2001, quando foi ajuizada uma primeira Ação Civil Pública (ACP) transferindo a competência do licenciamento ambiental da usina para um órgão federal (o Ibama). Desde então, o MPF vem sendo um dos atores mais presentes nas disputas canalizadas pela usina, tanto a partir de ações judiciais como extrajudiciais. As informações coletadas nesta pesquisa revelam que havia grandes diferenças entre os procuradores envolvidos no caso. Parte dos procuradores entendia a defesa de comunidades afetadas como o cerne de seu trabalho e lutava proativamente para defendê-las. Outros procuradores, no entanto, se apresentavam como atores "neutros” e “objetivos”, cuja função era somente a de fiscalizar o cumprimento da lei, e geralmente se restringiam aos instrumentos convencionais que um procurador tem à sua disposição.

Chamo esses procuradores, respectivamente, de ativistas e protocolares. ${ }^{5}$ Inspirado na definição de ativismo em Abers (2019) como "um

3 A Norte Energia (NE) representa o consórcio que ganhou o leilão da usina de Belo Monte - realizado pela Agência Nacional de Energia Elétrica (Aneel) em 2010.

4 Para mais informações sobre o histórico de implementação da usina, ver Pereira (2014).

5 A insistência dos procuradores em questionar a usina levou alguns deles a serem acusados de "ativistas". De acordo com entrevistados, trata-se de uma estratégia para deslegitimar e descreditar a ação dos procuradores (Entrevista 21, MPF, 2016; Entrevista 79, MPF, 2017). É importante ressaltar que o argumento desenvolvido neste trabalho de que procuradores constroem compromissos com causas não compartilha desta crítica. O caráter compromissado das ações dos procuradores não é considerado aqui como um desvio de sua atuação, mas como uma evidência de que o engajamento com causas não opera somente nas esferas da sociedade - e que a ideia de um Estado "neutro" e "imparcial” se desmancha na ação de servidores culturalmente situados (CASTILHO; LIMA; TEIXEIRA, 2014). 
certo tipo de ação que envolve a busca de oportunidades para defender causas contenciosas", mostro como esses dois tipos de procuradores variam crucialmente em (pelo menos) duas dimensões: $i$ ) o tipo de ideias que motivam os atores e ii) os tipos de táticas que acionam. Vale esclarecer que essa distinção pode ser melhor compreendida enquanto continuum e não como uma dicotomia. Procuradores ativistas não são sempre ativistas, assim como procuradores protocolares não se comportam dessa maneira o tempo todo. Procuradores "ativistas" e "protocolares” funcionam como tipos ideais - recursos analíticos que nos ajudam a compreender a realidade (WEBER, 1978). A pergunta central que este trabalho busca responder é: por que alguns procuradores se tornam ativistas e outros não?

Para responder a esta pergunta, lanço mão de três fontes de dados: i) 25 ações civis públicas; ii) 82 entrevistas semiestruturadas com atores-chave; e iii) observação de reuniões, em sua maioria entre procuradores e grupos atingidos e/ou OMSs. Mostro neste capítulo que a maior parte dos procuradores ativistas se tornou ativista após entrar no MPF. Em outras palavras, trata-se de um caso em que o efeito de self-selection tem baixo poder explicativo. Mostro ainda que o ethos organizacional do MPF no Pará, apesar de incentivar o ativismo de procuradores, não era condição suficiente para engajamento no ativismo, visto que procuradores situados nesse mesmo contexto organizacional tomaram rumos bastante diferentes. Argumento neste capítulo que procuradores se tornaram ativistas à medida que interagiam com comunidades afetadas pelo empreendimento e com movimentos sociais locais. Mais especificamente, argumento que por meio de práticas comunicativas, nas quais procuradores descobriam os problemas enfrentados por esses grupos e mediavam seus conflitos com tomadores de decisão da usina, procuradores internalizavam as demandas desses grupos, criando e fortalecendo compromissos com suas causas.

Este capítulo está dividido em seis seções, além desta introdução. Primeiro, reflito sobre a literatura de ativismo institucional e desenvolvimento de compromissos. Na segunda seção, apresento brevemente a trajetória do Ministério Público no Brasil, buscando reconstruir os processos que dão origem a esse órgão “defensor da sociedade” (ARANTES, 2002). Na seção seguinte, ilumino as diferenças no envolvimento entre procuradores ativistas e procuradores protocolares no caso de Belo Monte. Na quarta 
seção, explico o papel das trajetórias e do ethos organizacional do MPF no engajamento de procuradores com causas de grupos atingidos. Posteriormente, discuto como interações de descobertas e mediações desenvolviam e solidificavam o compromisso de procuradores. Por fim, apresento breves considerações finais onde resumo o argumento do capítulo e comento sobre possíveis linhas de pesquisas futuras.

\section{Ativismo dentro de instituições}

Existe uma crescente literatura em torno do papel de ativistas dentro de instituições. De fato, vimos surgir nos últimos anos uma variedade de termos para definir esses atores, tais como "inside activists" (BANASZAK, 2010; HYSING; OLSSON, 2017), “institutional activists” (SANTORO; MCGUIRE, 1997; PETTINICCHIO, 2012; ABERS; TATAGIBA, 2015), “activist bureaucrats” (RICH, 2013), “workplace activists” (SCULLY; SEGAL, 2002; RAEBURN, 2004), “tempered radicals” (MEYERSON; SCULLY, 1995) e “guerrilla governments” (O’LEARY, 2014). Estes autores se apoiam em diferentes definições; neste capítulo, sigo a proposta de Abers (2019) de conceitualizar ativistas institucionais a partir de duas dimensões: o tipo das ideias dos atores e as ações que eles promovem. Para ela, o ativismo é definido primeiramente pelo compromisso com uma causa - uma ideia que "da perspectiva de quem a defende, precisa ser protegida contra forças poderosas de estabilidade ou mudança” (ABERS, 2019, tradução nossa $)^{6}$ - e por um comportamento proativo ou criativo. De uma maneira geral, o principal foco desse grupo de pesquisadores tem sido investigar como burocratas ativistas influenciam políticas públicas (SANTORO; MCGUIRE, 1997). No entanto, pouca atenção tem sido dedicada à compreensão de como e por que alguns burocratas se tornam ativistas.

Uma primeira hipótese é que esses servidores já adentram instituições com compromissos prévios ou disposição para o ativismo, “carregando

6 “[...] from the perspective of believers, needs to be defended against powerful forces of either stability or change.” (ABERS, 2019). 
esse ativismo para dentro de suas carreiras” (GAGNE, 1996, p. 90, tradução nossa). ${ }^{7}$ Estudos precedentes encontraram evidência de self-selection (EISENSTEIN, 1989; RAEBURN, 2004; BANASZAK, 2010; ABERS, 2019). Banaszak (2010, p. 76, tradução nossa), por exemplo, notou que a maioria das ativistas radicais "já eram fortes feministas quando entraram no governo”. ${ }^{8}$ Similarmente, Hysing e Olsson (2017, p. 82, tradução nossa) argumentam que "em grande medida, pessoas já tem suas crenças e valores políticos definidos quando entram em uma organização”. ${ }^{9}$ Na literatura de movimentos sociais, uma das explicações para o engajamento no ativismo são as disposições que os indivíduos desenvolvem em suas trajetórias. Estudos apontam que experiências de vida (MISCHE, 2008) e participação em atividades promovidas por organizações de movimentos sociais, como protestos e ocupações (HIRSCH, 1990; GAMSON, 1991) podem levar a um comportamento ativista. O ponto central aqui é que essa variedade de experiências pode criar uma disposição para o ativismo (SILVA; RUKOWSKI, 2016).

Uma segunda hipótese se refere ao contexto organizacional no qual burocratas estão inseridos. Para alguns autores, organizações socializam atores de maneiras distintas, que podem levar ao desenvolvimento de compromissos (SCULLY; SEGAL, 2002). Afinal, "experiências de trabalho influenciam sistemas de crenças” (HOOGHE, 1999, p. 441, tradução nossa), ${ }^{10}$ visto que "organizações trabalham na socialização dos seus membros [...] possibilitando que indivíduos se identificam com determinados papéis” (FILLIEULE, 2010, p. 7, tradução nossa). ${ }^{11}$ Essa socialização pode ocorrer, por exemplo, por meio de "habitats organizacionais (grupos formais e redes informais)”, nos quais ativistas delineiam estratégias de ação e

7 "[...] feminists achieved their goals by carrying their activism into their careers." (GAGNE, 1996, p. 90).

8 "[...] were usually already strong feminists when they entered government." (BANASZAK, 2010, p. 76).

9 "Beliefs, values, and conceptions are certainly formed outside organizations to a large extent.” (HYSING; OLSSON, 2017, p. 82).

10 “Experiences in the workplace influence belief systems.” (HOOGHE, 1999, p. 441).

11 "Organizations also do a lot of work in socializing their members [...] which allows individuals to identify the different roles they face." (FILLIEULE, 2010, p. 7). 
compartilham experiências (KATZENSTEIN, 1998, p. 19, tradução nossa). ${ }^{12}$ Hysing e Olsson (2017, p. 83) apoiam (pelo menos em parte) esse argumento, notando que "algumas normas, valores e preferências são ajustadas e formadas por meio do envolvimento de indivíduos em organizações” (tradução nossa; ver também COSLOVSKY, 2011). ${ }^{13}$

Uma terceira hipótese foca nas interações estabelecidas pelos burocratas. Aqui, o mecanismo de engajamento no ativismo parece se sustentar em como ativistas são influenciados por seus “colegas das ruas” (RAEBURN, 2004, p. 39), que podem mobilizar atores dentro de instituições e persuadi-los a acreditar nos objetivos que promovem (BINDER, 2002, p. 222). O engajamento no ativismo é visto aqui como um processo intrinsicamente coletivo, porque "apesar da motivação estar enraizada em características psicológicas individuais, ela é construída e desenvolvida a partir de interações” (MELUCCI, 1989, p. 31, tradução nossa). ${ }^{14}$ Melucci (1989, p. 31) argumenta ainda que, por meio de interações, indivíduos "influenciam uns aos outros, negociam, e assim estabelecem frameworks conceituais e motivacionais para agir” (tradução nossa). ${ }^{15}$ Estudos anteriores evidenciaram que ativistas, em diversos momentos, se engajam em redes com organizações de movimentos sociais (BANASZAK, 2010; RICH, 2013; ABERS; TATAGIBA, 2015). Contudo, os processos por meio dos quais essas interações levam ao desenvolvimento de compromissos permanecem pouco claros.

12 “[...] organizational habitats (formal groups and informal networks).” (KATZENSTEIN, 1998, p. 19).

13 “[...] some norms, values, and preferences are adjusted and formed through individuals' involvement with organizations.” (HYSING; OLSSON, 2017, p. 83).

14 "While motivation is rooted in individual psychological traits, it is constructed and developed through interaction.” (MELUCCI, 1989, p. 31).

15 “[...] individuals interact, influence each other, negotiate and hence establish conceptual and motivational frameworks for action." (MELUCCI, 1989, p. 31). 


\section{Métodos}

O caso de Belo Monte emerge como cenário ideal para entender porque alguns burocratas se engajam em causas e outros não, visto que ele amplia a distância na variável dependente que busco explicar ao analisar casos de procuradores não compromissados e procuradores altamente compromissados. Para responder à pergunta de como alguns procuradores se tornaram ativistas, utilizei três fontes de dados. Primeiramente, analisei todas as ações judiciais ajuizadas pelo MPF no caso de Belo Monte entre 2011 e 2016 ( $\mathrm{N}=25)$, cuja maioria era composta por ações civis públicas (ACPs), um "instrumento jurídico que permite a representação, junto ao Poder Judiciário, de interesses coletivos, difusos e individuais homogêneos" (KERCHE, 2007, p. 274-275) ${ }^{16}$ Essas ações foram classificadas com base nas demandas de procuradores e nos argumentos usados para justificar essas demandas. Tais documentos me ajudaram a situar o quão central seria a defesa de comunidades impactadas na agenda de procuradores, bem como a entender os enquadramentos pelos quais procuradores tratavam esses grupos, e as ações que eles promoviam para defendê-los.

Como eu buscava entender as motivações, os valores e as práticas (PUGH, 2013, p. 50) de procuradores, também conduzi 82 entrevistas ao longo de um período de seis anos (2012-2018). As entrevistas foram conduzidas em formato semiestruturado e duraram em média 1-2 horas. Todas as entrevistas (à exceção de duas) foram gravadas e transcritas, com a permissão dos entrevistados. Uma vez que minha população de interesse não era grande, e porque procurei identificar casos que contrariassem o que eu buscava explicar (BECKER, 1998, p. 123), tentei entrevistar o maior número de procuradores possível. Primeiramente, compilei uma lista com todos os procuradores que assinaram ACPs no caso de BM (17). Entrei em contato com todos eles, e consegui entrevistar doze (dos quais cinco foram

${ }^{16}$ Vinte e duas das ações eram ações civis públicas. Duas outras eram ações de improbidade administrativa e uma era uma ação cautelar. 
entrevistados duas vezes) ${ }^{17}$ Entrevistei sete procuradores do escritório de Altamira, três de Belém e dois de Brasília.

Também entrevistei membros de comunidades afetadas $(\mathrm{N}=12)$ e de organizações de movimentos sociais $(\mathrm{N}=32)$, duas lideranças foram entrevistadas duas vezes, e uma delas três vezes. Fiz uma lista inicial de todas as OMSs envolvidas no caso de Belo Monte por meio de cartas públicas enviadas a autoridades e de estudos anteriores desenvolvidos sobre o caso (PEREIRA, 2014). As entrevistas remanescentes foram selecionadas via snow-ball (WEISS, 1995), ou seja, por meio de perguntas aos entrevistados sobre outras organizações envolvidas com o caso de Belo Monte que eu poderia entrar em contato. Um procedimento similar foi feito para estabelecer quais agentes estatais - além dos procuradores - seriam entrevistados. Consegui entrevistar 13 atores estatais, incluindo servidores do Ibama, da Fundação Nacional do Índio (Funai) e do Instituto Nacional de Colonização e Reforma Agrária (Incra) e da Defensoria Pública (da União e do estado do Pará). Finalmente, também entrevistei pesquisadores que colaboraram com o MPF $(\mathrm{N}=5)$ e um funcionário da Norte Energia. Os nomes dos entrevistados foram suprimidos para preservar sua identidade. Destarte, ao citar falas de entrevistados apenas listo o número da entrevista e (quando aplicável) a organização a qual o indivíduo faz parte.

De modo a triangular as informações obtidas nas entrevistas (TAYLOR; BOGDAN; DE VAULT, 1998), também observei quatorze reuniões (que duraram entre $1 / 2$ e 2 horas). Sete delas envolveram procuradores e organizações de movimentos sociais e/ou comunidades afetadas. Atores estatais de outros órgãos estiveram presentes em três dessas reuniões. O restante dessas reuniões ocorreu na Defensoria Pública (2), e entre organizações de movimentos sociais (5). A observação participante foi fundamental para comparar o que procuradores diziam que faziam com o que eles efetivamente praticavam (JEROLMACK; KHAN, 2014). Uma importante limitação deste estudo, no entanto, é que apenas consegui observar reuniões de um dos procuradores.

${ }^{17}$ Vale notar que nem todos os procuradores estavam trabalhando ativamente no caso de $\mathrm{BM}$ no momento em que foram entrevistados. Muitos deles haviam trabalhado no caso no passado e mudado de estado e/ou temática posteriormente. 


\section{Os meninos superpoderosos e a autonomia do MPF}

Em 2007, uma reportagem na revista Época comparou procuradores brasileiros à série de TV “As Meninas Superpoderosas”, na qual três meninas usam superpoderes para lutar contra vilões e proteger sua cidade. Esse artigo criticava as constantes intervenções de procuradores em projetos de energia, argumentando que "jovens com autonomia garantida por lei, os procuradores do Ministério Público mostram sua força e atravancam a infraestrutura do país” (PAUL, 2007).

O Ministério Público é realmente uma instituição singular no Estado brasileiro, principalmente após sua reforma institucional no final do último século. Uma série de leis durante as décadas de 1970 e 1980 - incluindo a Constituição Federal de 1988 - empoderaram significativamente procuradores, ao conferir-lhes "alto grau de independência funcional e controle completo sobre as ações que conduzem” (ARANTES, 2007, p. 329), abrindo a porta para que eles atuem como "agentes políticos da lei” (ARANTES, 2002, p. 80). As atribuições de procuradores visivelmente extrapolam a área criminal, visto que procuradores atuam em uma variedade de temáticas, "incluindo preservação ambiental, direitos de minorias, saúde pública, entre outras” (COSLOVSKY, 2011, p. 73, tradução nossa). ${ }^{18}$

Apesar de, formalmente, procuradores do MP possuírem a liberdade para se engajar em diversos conflitos políticos, pesquisas prévias revelam que a instituição cria uma variedade de incentivos para que os procuradores sejam cautelosos - isto é, justamente para que não se transformem em ativistas. O processo de seleção da organização, que consiste em uma série de exames, na prática avalia "se os candidatos se vestem de maneira apropriada e apresentam comportamento conservador, se eles escondem filiações políticas, e demonstram respeito a autoridade" (COSLOVSKY, 2011, p. 76-77, grifo nosso, tradução nossa). ${ }^{19}$ Esse processo de socialização

18 "[...] including environmental preservation, minority rights, public health, and more." (COSLOVSKY, 2011, p. 73).

19 "[...] whether candidates dress and behave conservatively, hide political affiliations, demonstrate unwavering respect for authority.” (COSLOVSKY, 2011, p. 76-77, grifo nosso). 
continua quando candidatos recebem treinamento e começam a trabalhar, visto que "a maioria das políticas gerenciais adotadas pelo MP prioriza diligência e consistência ao invés de criatividade, e cautela e processamento de casos no lugar de resolver problemas criativamente" (COSLOVSKY, 2011, p. 75-76, tradução nossa). ${ }^{20}$

Dentro desse ambiente organizacional, contudo, existem diferentes tipos de procuradores, que foram classificados em duas categorias por pesquisas anteriores: de um lado, o promotor $^{21}$ de fatos, que

indica a tendência de alargamento das funções dos promotores para muito além da esfera jurídica, tornando-os verdadeiros articuladores políticos nas comunidades em que trabalham. (SILVA, 2001, p. 140).

Do outro, aparece o promotor de gabinete, isto é, o “agente judiciário cuja prioridade é o trabalho 'processual' - propor e acompanhar medidas judiciais - e cuja ação na defesa dos interesses metaindividuais se dá, sobretudo, pela via judicial” (SILVA, 2001, p. 140, grifo da autora). Tanto para Silva quanto para Coslovsky, o principal fator que diferencia esses dois tipos de procuradores são as estratégias acionadas por eles: enquanto promotores de gabinete tendem a preferir ações judiciais, promotores de fato geralmente utilizam-se de meios extrajudiciais, como negociações e processos administrativos. Seu objetivo principal, afinal, é solucionar problemas.

Pouco foi dito, no entanto, sobre as diferentes motivações de procuradores. Que tipos de problemas eles buscam resolver e por quê? Apesar de Silva (2001, p. 138) argumentar que procuradores de fato se tornam "articuladores políticos” e priorizam “questões que abrangem um grande número de pessoas ou que estejam ligadas a políticas e programas públicos”, ela não mergulha

20 "Most managerial policies adopted by the MP reward diligence and consistency rather than creativity, and cautious case-processing rather than creative problem-solving." (COSLOVSKY, 2011, p. 75-76).

${ }^{21}$ A diferença entre promotores e procuradores refere-se ao âmbito no qual eles têm competência para atuar: promotores atuam no âmbito estadual, e procuradores no federal. 
a fundo em que tipos de questões são essas. Uma pergunta central para a compreensão desse órgão conhecido como "defensor público da sociedade" (ARANTES, 2002, p. 192), portanto, seria identificar os interesses sociais que os procuradores buscam defender (CRAWFORD, 2008, p. 627). No caso de Belo Monte, argumento que as diferenças entre procuradores não dependem apenas das estratégias e recursos que eles acionam, mas de suas motivações e percepções em torno do que significa ser um procurador da república.

\section{Lutando criativamente por causas: Procuradores ativistas no caso de Belo Monte}

Alguns procuradores vieram com mais sangue nos olhos para fazer o trabalho deles. E alguns procuradores tiveram uma atuação mais protocolar, não estavam com tanto sangue nos olhos. (Entrevista 76, Instituto Socioambiental, 2016).

Ao entrevistar membros de organizações de movimentos sociais em Belém e Altamira, logo percebi que o MPF era um grande aliado em suas lutas antibarragem e por melhores políticas de compensação. Para alguns, o MPF era “sempre parceiro" (Entrevista 42, Movimento dos Atingidos por Barragens, 2016). Outros ressaltam que "se hoje tem MPF, foi uma luta nossa junto também ao MPF para que tivesse aqui nessa região" (Entrevista 26, Movimento Xingu Vivo Para Sempre, 2016). No entanto, grande parte dos entrevistados, quando perguntados sobre sua percepção acerca do MPF, ressaltava o trabalho de alguns procuradores específicos, evitando generalizar. Era comum que lideranças e/ou comunidades atingidas ressaltassem o "engajamento" (Entrevista 30, Conselho Indigenista Missionário, 2016) ou o “compromisso” de determinados procuradores (Entrevista 34, Fundação Viver, Produzir e Preservar, 2016). Mas não era bem assim com todos os procuradores: “Muitas vezes não é o MPF, também depende das pessoas, então a gente já se deparou aqui com gente do MPF completamente avesso às lutas sociais” (Entrevista 18, Federação de Órgãos para Assistência Social e Educacional, 2016).

As entrevistas com procuradores corroboram essa percepção. Alguns desses procuradores desenvolveram compromissos com as lutas de 
comunidades afetadas pela barragem, tornando a luta pelo direito à compensação o motor central de seu trabalho. Chamo esses procuradores de ativistas. O conceito de ativismo é estruturado, segundo Abers (2019), em duas dimensões: o compromisso que atores constroem com determinadas causas e sua proatividade - e criatividade - ao lutar por elas.

A primeira dimensão se refere ao aspecto ideacional do ativismo. No caso de Belo Monte, a variação em torno desse eixo entre procuradores ativistas e protocolares era notável. Todos os procuradores ativistas mobilizaram a defesa de comunidades afetadas como a motivação central de seu trabalho - bem como a justificativa para uma presença tão intensa do MPF naqueles casos. Para algum deles, lutar por esses grupos é uma "missão de vida” (Entrevista 79, MPF, 2017). Outros entendiam que “o MPF lá em Altamira tinha uma função fundamental de dar voz à população” (Entrevista 77, MPF, 2017), de ser "o braço jurídico desse movimento [de atingidos por barragens]” (Entrevista 1, MPF, 2012).

Procuradores protocolares, por outro lado, buscavam se distanciar de qualquer tipo de vínculo ideacional, geralmente ressaltando a imparcialidade que rege o cargo de procurador e sua missão de fazer com que a lei seja cumprida. Como explica uma das entrevistadas: "É o nosso papel garantir que as coisas sejam feitas na legalidade, na minha opinião. É diferente de alguma coisa voltada a determinado lado” (Entrevista 53, MPF, 2016). De acordo com outro procurador, o MPF

deve garantir que a Constituição seja respeitada. A política em sua essência não faz parte do trabalho do MPF, porque política é sobre fazer leis, e o nosso papel é fazer com que elas sejam cumpridas. (Entrevista 81, MPF, 2018).

Nessa percepção, os procuradores não podem "se opor a um projeto político de poder, porque isso aí já vai para o campo da política”; pelo contrário, eles "têm que ser técnicos e objetivos e [...] ter uma visão equidistante da questão”, não podendo “adentrar no campo do comprometimento com aquele ou este movimento social” (Entrevista 28, MPF, 2016). Diferentemente de seus colegas ativistas, procuradores protocolares não se enxergam como atores compromissados. No entanto, o ativismo não envolve apenas essa dimensão ideacional, mas também um comportamento 
proativo (KELLY, 1999; PETTINICCHIO, 2012). Nessa segunda dimensão do ativismo, também encontrei grande variação.

Uma das principais armas de procuradores no caso de Belo Monte foram as ações judiciais. De fato, entre 2001 e 2016 procuradores (ativistas e protocolares) ajuizaram 25 ações. Apesar de não ser possível comparar sistematicamente esses dois tipos de procuradores nas Ações Civis Públicas (ACPs) - visto que $75 \%$ delas (20) foram assinadas por múltiplos procuradores ${ }^{22}$-, encontramos importantes padrões ao analisar seu conteúdo. As ações ajuizadas foram analisadas por meio do software NVivo 10 e classificadas em termos dos argumentos levantados por procuradores e das demandas que eles faziam.

A análise de conteúdo revelou que $84 \%$ das ações (21) mencionavam impactos em comunidades afetadas. Algumas das ações foram elaboradas especificamente para lidar com impactos em grupos sociais, como a ACP que buscava garantir o cumprimento de condicionante para os Jurunas do km $17 .{ }^{23}$ Em outras ações, esses impactos apareciam tangencialmente, tais como em ACP que tratava sobre os efeitos decorrentes de problemas na elaboração do Estudo de Impacto Ambiental. ${ }^{24}$ Procuradores buscavam proteger essas populações de diferentes maneiras, às vezes por meio de demandas mais disruptivas como, por exemplo, exigindo a suspensão do projeto (mencionado 2 vezes), exigindo mudanças nas políticas de compensação (13), inclusão de outros grupos nessas políticas (5) ou, ainda, o cumprimento de políticas de compensação já existentes (15). ${ }^{25}$ Em resumo, isso sugere que procuradores prestavam atenção especial às comunidades afetadas. Os efeitos dessas ações judiciais, contudo, foram bastante limitados. Embora diversas das ações tivessem conseguido paralisar o processo de implementação da usina por alguns dias, elas foram derrubadas em decisões judiciais posteriores (Entrevista 21, MPF, 2016), principalmente devido à suspensão de segurança, mecanismo

22 De acordo com entrevistados, essa era uma estratégia deliberada para fortalecer a credibilidade das ações (Entrevista 21, MPF, 2016).

${ }^{23}$ ACP n $^{\circ}$ 1655-16.2013.4.01.3903.

${ }^{24}$ ACP n $^{0} 25999-75.2010 .4 .01 .3900$.

${ }^{25}$ Cumpre lembrar que diversas das ações tinham múltiplas demandas, o que significa que usei mais de uma categoria para classificá-las. 
que interrompe o julgamento do mérito de ações judiciais por se tratar de um projeto de “interesse nacional” (Entrevista 11, MPF, 2015).

Quando olhamos para além dos tribunais, começamos a perceber algumas características que distinguem procuradores ativistas e protocolares. A fim de contornar os obstáculos do poder judiciário, tanto procuradores ativistas como protocolares buscavam acionar táticas extrajudiciais. Procuradores protocolares revelaram que eles constantemente negociavam com a Norte Energia e se utilizavam do inquérito civil como mecanismo de negociação. Procuradores ativistas, no entanto, davam um passo a mais. Quando os instrumentos tradicionais falhavam, eles iam além e acionavam táticas criativas.

Um exemplo é a articulação de procuradores ativistas para coordenar uma audiência pública na tentativa de convencer a Defensoria Pública da União (DPU) a se instalar na cidade de Altamira para lidar com os problemas de reassentamento de grupos atingidos por Belo Monte. ${ }^{26}$ Indivíduos afetados pela usina bateram à porta do MPF à medida que estavam sendo forçados a deixar suas casas, que seriam alagadas pela usina. Mas esse "não é caso para o MP, era caso para a Defensoria Pública. Quem trata do individual é a defensoria. No MP a gente trata de [...] casos que são coletivos. Só que a Defensoria Pública não estava lá” (Entrevista 14, MPF, 2016). Comovida com o sofrimento desses indivíduos, a procuradora ativista organizou uma audiência pública cujo objetivo

era trazer a Defensoria Pública da União para Altamira, porque não tinha Defensoria Pública, e o resultado foi esse, hoje eles estão lá [...] porque a opção foi justamente tratar de uma maneira diferente [e não ajuizar uma ação]. (Entrevista 14, MPF, 2015).

Outro exemplo é o caso dos ribeirinhos. Como a Norte Energia se recusava a compensar as duas casas que os ribeirinhos tradicionalmente

${ }^{26}$ Até 2015, Altamira não tinha um escritório da Defensoria Pública da União, apenas uma sede da Defensoria Pública do Estado do Pará que, apesar de também ter atuado no caso de Belo Monte, permaneceu quase inativa durante alguns anos pela falta de defensores na região (Entrevista 55, Defensoria Pública do Estado do Pará, 2016). 
têm - uma ao longo do rio e outra na cidade - a procuradora ativista organizou uma inspeção interinstitucional, convocando membros da comunidade acadêmica, de OMSs e de outras agências estatais para observar, no próprio local onde os povos ribeirinhos habitavam, a realidade do processo de desapropriação desse grupo. Ela conta que

a ideia da inspeção foi isso: a gente não tem condições de ouvi-los numa audiência pública. [...] Então a ideia foi ir para os locais deles para que eles pudessem falar nas condições, no tempo deles. (Entrevista 67, MPF, 2016).

Esses casos revelam uma diferença crucial entre procuradores ativistas e protocolares: apesar de ambos lançarem mão de estratégias extrajudiciais, procuradores ativistas eram persistentes e utilizavam táticas criativas para alcançar seus objetivos. Procuradores protocolares, no entanto, não concebiam ou usavam táticas criativas que fugissem do repertório de ação tradicionalmente associado ao trabalho de procuradores (Entrevistas 28 e 53, MPF, 2016; Entrevista 81, MPF, 2018). Apesar de também atuarem em problemas relacionados ao caso de Belo Monte, procuradores protocolares não se mostravam proativos para resolver os obstáculos que enfrentavam, tampouco priorizavam o caso. Vemos, portanto, que as ações e motivações de procuradores ativistas e protocolares são bastante diferentes. Mas o que explica essa variação?

\section{Trajetórias e socialização organizacional}

Estudos anteriores encontraram evidências que ativistas institucionais já eram ativistas antes de entrarem nas instituições em que trabalhavam (GAGNE, 1996; RAEBURN, 2004; BANASZAK, 2010; HYSING; OLSSON, 2017). No caso de Belo Monte, trajetórias não tiveram alto poder explicativo no ativismo engajado de procuradores. Dos cinco procuradores ativistas entrevistados, apenas um deles tinha envolvimento prévio com lutas de grupos atingidos por barragens (e com atividades relacionadas a movimentos sociais de maneira geral). Ele explica: 
Não foi o Ministério Público que me escolheu, fui eu que escolhi. Eu quero defender a população tradicional da Amazônia. Onde é que eu posso fazer isso melhor? Na advocacia? Não. Na defensoria? Não. No MPF. Aqui é o lugar por excelência onde se faz essa defesa, então eu disse: eu quero ir para aí. Então quando eu passo no concurso, já foi completamente direcionado, que aqui eu ia cumprir a minha missão. (Entrevista 79, MPF, 2017).

Nesse caso, fica claro como o procurador já chega ao MPF altamente compromissado com causas de grupos atingidos por grandes empreendimentos. Todos os outros procuradores ativistas, contudo, não eram ativistas antes de entrar para o MPF. Na realidade, procuradores evitavam ir para o MPF de Altamira devido ao alto custo de vida da cidade (Entrevista 12, MPF, 2015). Um procurador que se identificava com comunidades ribeirinhas afirmou que "a maioria dos procuradores [que vinha para Altamira] chegava do Sul, com uma realidade completamente diferente” (Entrevista 79, MPF, 2017). Portanto, eles tinham pouca ou nenhuma experiência com lutas de comunidades tradicionais, como povos indígenas ou ribeirinhos. Mas como eles desenvolvem compromissos após adentrarem o MPF?

Outra variável explicativa é o contexto organizacional no qual procuradores são socializados. A ideia por trás dessa hipótese é de que a socialização em um contexto organizacional que promove ativismo aumenta as chances de atores se tornarem ativistas (KATZENSTEIN, 1998; SCULLY; SEGAL, 2002; FILLIEULE, 2010). Em estudo sobre procuradores em São Paulo, Coslovsky (2011) argumenta que o ativismo de procuradores pode ser explicado por estruturas e processos organizacionais. Minha pesquisa mostrou que apesar do contexto organizacional ser um passo importante no desenvolvimento de compromissos, ele não é uma condição suficiente para engajamento no ativismo.

Todos os procuradores ativistas afirmaram que o MPF no Pará tinha um ethos diferente dos outros escritórios do MPF. Como mencionado anteriormente, procuradores no Brasil são geralmente treinados para esconder suas motivações políticas. Procuradores entrevistados disseram que sua experiência no Pará havia sido diferente, e que o MPF nesse estado era majoritariamente progressista e crítico à construção de hidrelétricas na 
Amazônia (Entrevista 21, MPF, 2016). Na realidade, mesmo antes de BM, o escritório do MPF em Belém já se mostrava altamente preocupado com a construção de hidrelétricas. Na época (2001), não havia escritório do MPF em Altamira. O MPF instalou uma sede em Altamira em $2006^{27}$ e, desde então, a maioria do trabalho relacionado a BM foi transferido de Belém para lá. Procuradores de Belém, contudo, permaneceram ativos no caso, principalmente por causa dos seus compromissos para ajudar comunidades afetadas (Entrevista 21, MPF, 2016; Entrevista 79, MPF, 2017).

Além disso, procuradores de Belém buscavam ajudar seus colegas de Altamira devido às altas taxas de rotatividade no escritório daquele município. ${ }^{28}$ De acordo com um deles,

foi por isso [rotatividade da PRM-Altamira] que nós dois nos mantivemos sempre tão ligados ao tema, para fazer essa memória. Independentemente de quem fosse o procurador que estava lá, a gente ajudava na transmissão até ele se empoderar daquele conhecimento e tocar sozinho. (Entrevista 21, MPF 2016).

Procuradores criaram inclusive um "grupo de trabalho" para discutir questões relacionadas a Belo Monte (Entrevista 79, MPF, 2017), estabelecendo assim "relações muito próximas e cooperativas" entre procuradores de Belém e Altamira (Entrevista 77, MPF, 2017). Como explica um dos procuradores:

Eu não consigo imaginar uma equipe como essa, engajada, capacitada. [...] Existe dentro do MP uma sensibilidade muito grande com relação a Belo Monte, a ponto de você ter um grupo, um centro de apoio, então você nunca está

27 A criação do escritório em Altamira foi motivada por intensos conflitos agrários e violência contra ativistas locais (Entrevista 78, MPF, 2016).

28 “O MPF de Altamira era considerado um gabinete de 'primeira lotação’ porque era habitado principalmente por procuradores recém-admitidos no MPF. A falta de infraestrutura da cidade, somada aos altos preços - principalmente após a construção da usina - não criava incentivos para procuradores escolherem vir para Altamira. Por isso, procuradores que iam para Altamira geralmente saíam quando tinham a oportunidade, e novos procuradores chegavam à cidade a cada dois anos em média.” (Entrevista 12, MPF, 2015). 
sozinho. Eu acho que isso talvez não aconteça em outras hidrelétricas, que às vezes o procurador fica lá mais sozinho. (Entrevista 14, MPF, 2015).

Procuradores em Belém não somente providenciavam suporte e ajudavam seus pares na análise dos casos em que trabalhavam, mas também socializavam seus colegas em um ambiente que problematizava a implementação de Belo Monte - bem como a construção de barragens de maneira geral - e enfatizava os impactos causados em grupos sociais locais. Um dos procuradores explica:

Como eu fazia, por exemplo, com os procuradores que chegavam do Sul, com uma realidade completamente diferente? Sabe qual era a tática? "Vai para a aldeia. Fica na aldeia”. [...] E quando voltava, voltava completamente mudado. Não tem pedagogia melhor do que essa de conhecer a realidade. $\mathrm{O}$ choque de realidade que levava era o suficiente para o cara vir e preparar a ação contra Belo Monte. (Entrevista 79, MPF, 2017).

Procuradores da PRM-Altamira eram, portanto, socializados em um ambiente que problematizava a implementação de BM e, ao mesmo tempo, ressaltava os impactos que a usina trazia a grupos atingidos. Procuradores entrevistados revelaram que esse suporte foi fundamental para que eles entendessem a complexidade das lutas políticas que estavam em jogo (Entrevistas 12 e 14, MPF, 2015). Isso parece apoiar a hipótese de que o engajamento no ativismo pode resultar de uma socialização organizacional (FILLIEULE, 2010; COSLOVSKY, 2011). No entanto, apesar de serem socializados em um ambiente que promovia o desenvolvimento de compromissos com causas relacionadas às lutas de grupos atingidos, nem todos os procuradores se tornaram ativistas. Durante minha última pesquisa de campo, em 2016, havia três procuradores trabalhando na PRM-Altamira. Desses três, um era claramente ativista, tendo inclusive recusado a possibilidade de sair de Altamira duas vezes para continuar atuando no caso de Belo Monte. Os outros dois, no entanto, se identificavam mais como neutros e imparciais (protocolares). Uma análise comparada entre esses 
procuradores nos permite, assim, dar mais um passo na compreensão sobre como servidores públicos se tornam ativistas. Os três procuradores não tiveram qualquer contato com lutas antibarragem ou experiências que os levassem a criar disposições para o ativismo antes de suas chegadas a Altamira. Além disso, eles foram socializados no mesmo ambiente organizacional. Afinal, o que explica o fato de alguns atores se tornarem ativistas e outros não quando "controlamos” pelas trajetórias e socialização organizacional?

\section{Descobertas e mediações}

A comparação entre os procuradores de Altamira revelou que o grau com que interagiam com comunidades afetadas e organizações de movimentos sociais variava dramaticamente. Durante minha ida à campo percebi, gradualmente, que grande parte dos grupos afetados entrevistados comunicava a procuradora ativista quando buscavam avançar suas demandas. Nas entrevistas, perguntava a membros de organizações de movimentos se eles haviam mantido algum tipo de relação com o MPF nos últimos anos em relação ao caso de Belo Monte. Em caso afirmativo, indagava-lhes com quais procuradores eles interagiam. Ao todo, entrevistei 36 ativistas de OMS em 2016 na cidade de Altamira, dos quais 26 informaram já ter interagido com a procuradora ativista. Ambos os procuradores protocolares, no entanto, só foram mencionados por 2 entrevistados cada um. Mas por que exatamente essas interações importam? E que tipo de interações procuradores estabelecem? As entrevistas e a observação de reuniões revelaram que procuradores estabelecem majoritariamente dois tipos de interação, que chamo aqui de descobertas e mediações.

Entendo por descobertas as práticas comunicativas nas quais procuradores ficam cientes dos problemas enfrentados por grupos afetados. À medida que descobrem os impactos que antes eram invisíveis, eles internalizam as demandas desses grupos e as colocam no topo de sua agenda. Já mediações dizem respeito às práticas comunicativas em que procuradores levam as demandas de grupos atingidos para as negociações com tomadores de decisão como, no caso de BM, em reuniões com funcionários da Norte Energia e servidores do Ibama e da Funai, responsáveis 
pela implementação da usina. ${ }^{29}$ Por meio de dessas práticas de mediação, procuradores solidificaram seus compromissos com as causas de grupos afetados, geralmente entendendo de quem era a culpa pelos problemas causados a essas comunidades. A figura 1 resume os processos pelos quais procuradores se tornavam ativistas.

Figura 1: Processos de engajamento em ativismo

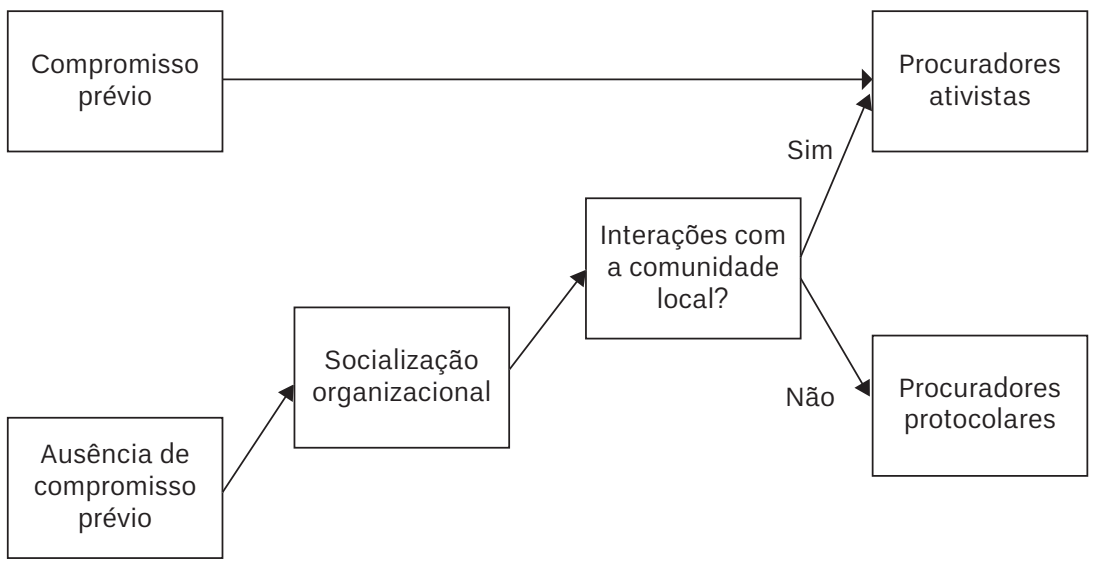

Como podemos ver, compromissos prévios são condições suficientes para o ativismo. Contudo, não foi uma variável com alto poder explicativo neste caso, visto que apenas um dos procuradores já se encontrava engajado com minorias étnicas antes de entrar para o MPF. Todos os outros procuradores que se tornaram ativistas seguiram um caminho similar: após serem socializados em uma organização que promovia o engajamento em comportamentos ativistas, eles interagiram com a comunidade local por meio de práticas de descobertas e mediações que os levaram a desenvolver e manter compromissos com as causas de grupos afetados pelo empreendimento.

${ }^{29}$ O conceito de mediação - também conhecido como brokerage - envolve a conexão entre dois ou mais atores previamente desconectados (MCADAM; TARROW; TILLY, 2001), ou parcialmente desconectados (MISCHE, 2008). Procuradores podem ser entendidos como mediadores à medida que conectam grupos afetados com outros atores que esses grupos não conseguiam atingir ou se sentiam ignorados por eles. 
Procuradores protocolares, apesar de serem socializados em um contexto organizacional semelhante, não mantiveram interações constantes com grupos afetados. Em outras palavras, práticas de descobertas e mediações não faziam parte de sua rotina de trabalho.

Todos os procuradores ativistas entrevistados interagiam constantemente com grupos afetados, ouvindo suas queixas e demandas e negociando com outros atores estatais envolvidos na implementação da usina. O MPF de Altamira, na realidade, se tornou o único aliado estatal dos grupos afetados e depositário de todas as suas esperanças, visto que esses grupos encontravam grande dificuldade de acesso à Norte Energia e a outros órgãos estatais, como o Ibama ${ }^{30}$ e a Funai. ${ }^{31}$ Insulados dos processos de negociação e decisão sobre Belo Monte, esses grupos voltaram sua atenção para o MPF, bombardeando procuradores com denúncias e informações sobre violações de direitos.

As entrevistas com procuradores ativistas revelaram que por meio das práticas de descobertas e mediações, eles internalizavam as demandas desses movimentos, construindo compromissos para lutar por suas causas. A procuradora ativista trabalhando em Altamira em 2016, por exemplo, contou que seu esforço em coordenar uma audiência pública na tentativa de convencer a Defensoria Pública a instalar uma sede em Altamira surgiu a partir da interação com grupos afetados:

Quando foi em setembro do ano passado [2014], me procurou uma senhora falando que ela queria uma casa, mas eles só estavam dando indenização, que a indenização para ela não dava, porque ela não conseguia comprar outra casa, e ela queria uma casa. [...] Aí eu falei para essa senhora: "a senhora espera lá fora, que eu vou com a senhora lá na empresa, pessoalmente”. [...] Aí cheguei com ela lá, aí como que funcionava na empresa,

${ }^{30}$ Até o final de 2015 - após a concessão da Licença de Operação (LO) de Belo Monte - o Ibama, por exemplo, não tinha nenhum servidor em Altamira que lidasse com o caso de Belo Monte. Consequentemente, diversos grupos da sociedade civil não conseguiam dialogar com o órgão: “você não tinha acesso ao Ibama, só via o prédio” (Entrevista 24, MXVPS, 2016).

31 Já a Funai, apesar de ter uma sede em Altamira envolvida no processo de Belo Monte, vive com pouquíssimos recursos: "Hoje se você chega dentro da Funai, para beber uma água tem que comprar, fazer vaquinha. Porque não tem recurso” (Entrevista 70, FUNAI, 2016). 
eu vi o seguinte: [...] a pessoa chega, aí ela recebe um papel com a avaliação da casa, quanto ela vai receber [...] Então não tem negociação nenhuma, porque você tem que aceitar o que eu estou te impondo. [...] Então quando eu vi isso, eu tive a nítida percepção de que a Norte Energia estava fazendo o papel dela, a Norte Energia é o empreendedor. Quem não estava lá era o Estado, quem não estava lá era a assistência jurídica gratuita que essa pessoa tinha que ter no momento da negociação. Então o erro estava aí. Então a audiência pública, o objetivo dela foi trazer o Estado para acompanhar as pessoas nas negociações. (Entrevista 14, MPF, 2015).

Podemos ver, portanto, como práticas comunicativas de descobertas foram o gatilho para o desenvolvimento de compromissos a favor dessas causas. Embora fosse apenas responsável por trabalhar em casos coletivos, descobrir a situação de remoção compulsória desses grupos levou a procuradora a se comprometer com a luta por melhores condições de reassentamento para eles, trazendo assistência jurídica para essas pessoas (Entrevista 14, MPF, 2015). O compromisso dessa procuradora foi fortalecido à medida que ela atuou como mediadora de conflitos de grupos afetados e tomadores de decisão no processo da usina. Uma das reuniões que observei ilustra esse efeito. Alguns dias antes da reunião, membros de OMSs entraram em contato com a procuradora, revelando que a empresa Norte Energia se recusava a fazer a manutenção dos equipamentos adquiridos para Unidades Básicas de Saúde (UBS) em povos indígenas. A procuradora, espantada, agendou uma reunião com funcionários da Norte Energia, chamando também representantes da Funai e da sociedade civil. Durante essa reunião, a procuradora perguntou aos funcionários da NE se eles cuidariam da manutenção dos equipamentos. Eles se negaram e disseram que isso era uma decisão da diretoria. A procuradora então disse que estava extremamente preocupada que essas UBS se tornassem “elefantes brancos” com nenhuma utilidade, ressaltando que o MPF e a NE teriam "uma discordância visceral nesse assunto" e que poderia ajuizar uma ACP incluindo danos morais caso a posição da empresa não mudasse. Por meio dessa prática de mediação, a procuradora então fortaleceu seu compromisso com comunidades indígenas que não estavam recebendo cuidados de saúde apropriados. 
Quando voltamos um pouco no tempo, vemos que interações - tanto práticas de descobertas como de mediações - foram descritas como relevantes por todos os procuradores ativistas entrevistados (que trabalharam no caso antes de minha ida à campo em 2016). A primeira ACP ajuizada pelo MPF no caso de BM em 2001, por exemplo, surgiu a partir de uma prática de descoberta na qual um procurador ativista visitou o povo indígena Juruna:

[...] a primeira ação de BM vai ser proposta depois de uma viagem minha à aldeia dos Juruna, na terra indígena Paquiçamba. [...] Quando eu vou nessa viagem ao Paquiçamba, um dos indígenas chega no meio da reunião com o que eles chamavam de palco de números, que era uma régua métrica. E tira aquela régua métrica da beira do rio e me entrega. Todo mundo ficou extremamente preocupado na reunião. [...] E aí quando eu volto para a procuradoria e faço as primeiras investigações [...] já estava sendo construída a terceira maior hidrelétrica do mundo já no final do EIA-Rima [Estudo de Impacto Ambiental/Relatório de Impacto Ambiental]. E aí foi a primeira ação. (Entrevista 79, MPF, 2017).

Podemos ver que, à medida que procuradores interagiam com comunidades afetadas pelo empreendimento, eles passaram a descobrir os impactos causados a esses grupos. De fato, todos os procuradores ativistas entrevistados ressaltaram a importância dos laços que eles desenvolveram com grupos afetados e organizações de movimentos sociais. Um dos procuradores ativistas explica:

A nossa relação com movimentos sociais [...] influencia a forma de desenvolver o pensamento, influencia a forma como vejo o direito, a forma como manuseio. [...] A relação com os movimentos sociais ajuda muitas vezes a abrir a cabeça do sujeito: “olha, o mundo urbano não é o único que existe. Tem esse mundo aqui que eu também tenho que entender”. (Entrevista 21, MPF, 2016).

Outro procurador ativista concorda: 
Acho que é fundamental dentro do MPF, sair do seu gabinete para entender a sociedade que te cerca. [...] A lógica do movimento social é fundamental porque a sociedade organizada te dá mobilidade na informação, [...] então acho que isso é fundamental. Tinha uma relação muito próxima deles. (Entrevista 77, MPF, 2017).

E ainda outro procurador ativista complementa:

a cabeça pensa onde os pés pisam. [...] Acho que um contato com a realidade local, você tem que ter, acho que isso que diferencia a atuação. Se você tem um contato com a realidade local, sua atuação muda. (Entrevista 78, MPF, 2017).

No caso de BM, práticas de descobertas e mediações faziam parte da rotina de procuradores ativistas, levando-os a desenvolver e manter compromissos com as comunidades afetadas pela usina. Procuradores protocolares, por outro lado, não interagiam com tanta frequência com grupos afetados ou com OMSs. Os próprios procuradores ativistas reconhecem que existe uma diferença na maneira como seus colegas abordam o trabalho na procuradoria:

Tem um pouco da personalidade de cada um, tem gente que é mais aberto ao diálogo, outros são mais fechados, gostam de trabalhar dentro do gabinete, receber a questão estritamente jurídica, só que eu não consigo dissociar a ideia da questão jurídica da questão social e política local. (Entrevista 77, MPF, 2017).

Entrevistas com organizações de movimentos sociais e grupos afetados corroboram com essa disparidade. Um dos membros da Cooperativa Mista dos Garimpeiros da Ressaca, Itata, Galo, Ouro Verde e Ilha da Fazenda (Coomgrif) conta que

nunca consegui falar com o [procurador]. Quando eu tentei falar com o [procurador], esse ano [2016], primeiro ele está de licença, depois voltou, aí encontrei com o [procurador], falei que tinha tentado falar com ele, estou aguardando até hoje. (Entrevista 48, COOMGRIF, 2016). 
Entrevistas com procuradores protocolares revelaram que eles não eram tão proativos quanto seus colegas ativistas. Sua rotina geralmente envolvia ficar dentro do gabinete. Apesar de interagirem às vezes com grupos afetados e movimentos, práticas de descobertas e mediação não faziam parte de sua rotina.

Figura 2: Processo de desenvolvimento de compromissos com minorias étnicas

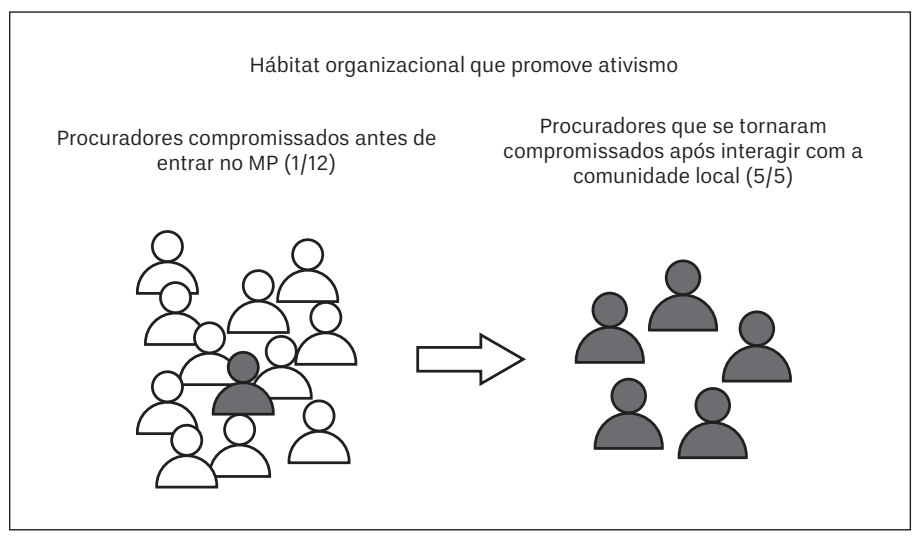

Para resumir, interações - e, mais especificamente, práticas de descobertas e mediações - são importantes porque, por meio delas, procuradores internalizam as demandas de grupos afetados, desenvolvendo e fortalecendo compromissos para defendê-los. A figura 2 resume o argumento deste capítulo. Ao contrário do que previam estudos anteriores (BANASZAK, 2010; HYSING; OLSSON, 2017), mostrei que ativistas institucionais não necessariamente entram para o Estado com compromissos prévios. A maior parte dos procuradores ativistas desenvolveu compromissos com causas após terem entrado no MPF. Situados em um contexto organizacional que promove ativismo, cinco procuradores saíram de seus gabinetes e passaram a interagir constantemente com a comunidade local, desenvolvendo e mantendo compromissos para lutar por suas causas. 


\section{Considerações finais}

Estudos sobre ativistas institucionais tendem a explicar o compromisso desses ativistas a partir de duas variáveis: disposições prévias, ou seja, a ideia de que burocratas já são ativistas antes de entrarem na administração pública, e socialização organizacional. Oberfield (2014) chama essas perspectivas de “disposicional” e "institucional”. Seu estudo argumenta que temos que olhar para esses dois fatores para entender a motivação de burocratas. Neste capítulo, mostrei que burocratas podem se tornar ativistas apesar de não terem disposição para isso. Mostrei ainda que a socialização organizacional não foi uma condição suficiente para o engajamento em comportamentos ativistas. Argumento neste trabalho que procuradores se engajavam no ativismo à medida que interagiam com a comunidade local, descobrindo seus problemas e mediando suas disputas. Por meio dessas práticas comunicativas, procuradores internalizaram os conflitos de comunidades afetadas, colocando-os em posição de evidência em suas agendas. Nesse sentido, este trabalho contribui para a literatura de ativismo institucional porque evidencia um caminho alternativo por meio do qual atores estatais podem se engajar em causas: a partir das interações que estabelecem com outros atores dentro e fora do Estado. Estudos futuros poderão investigar melhor o impacto de contextos organizacionais ao comparar ativistas institucionais situados em diferentes tipos de organização (que promovam ou desencorajem comportamentos ativistas, por exemplo).

Ao mostrar como procuradores se tornaram mediadores e desenvolveram compromissos com causas, este capítulo também contribui para o debate em torno dos mecanismos de mediação (também conhecido como brokerage). Diferentemente de estudos anteriores, que abordam como a mediação facilita processos de comunicação ou a criação de novos atores coletivos (MCADAM; TARROW; TILLY, 2001), foquei nos impactos não em quem é mediado, mas nos próprios atores que executam o papel de mediador. O potencial de gerar compromissos da mediação também coloca em xeque visões de mediadores como atores neutros (SABATIER, 1998) ou guiados por interesse próprio (INGOLD; VARONE, 2012), indicando que as motivações de brokers são melhor compreendidas não como premissas, mas como perguntas empíricas contextualmente situadas. 
Ademais, a trajetória que transforma procuradores em ativistas aqui exposta abre caminhos para o debate sobre como movimentos afetam o Estado e, mais especificamente, como movimentos fazem uso de instituições do sistema legal para promover suas agendas (ZEMANS, 1983; MCCANN, 1994). A crescente literatura sobre legal mobilization tem demonstrado que arenas legais emergiram como espaços-chaves por meio dos quais movimentos buscam produzir mudanças (LOSEKANN, 2013). Neste capítulo, expus como mobilizar e engajar procuradores pode ser uma tática eficiente para as OMSs. Em um caso no qual ações diretas - como protestos e ocupações - tiveram sucesso limitado, adiando a construção da usina por apenas alguns anos (Pereira, 2014), o trabalho de procuradores foi crucial para garantir que comunidades ribeirinhas afetadas pela usina fossem, pela primeira vez na história do Brasil, reassentadas na beira do rio, mantendo as condições de vida que tinham antes da barragem.

\section{Referências}

ABERS, Rebecca Neaera. Bureaucratic activism: pursuing environmentalism inside the Brazilian state. Latin American Politics and Society,v. 66, n. 2, p. 22-44, mai 2019.

ABERS, Rebecca Neaera; TATAGIBA, Luciana. Institutional Activism: Mobilizing for Women's Health from Inside the Brazilian Bureaucracy. In: ROSSI, Frederico; von BULOW, Marisa. Social Movement Dynamics: New Perspectives on Theory and Research from Latin America. New York: Routledge, 2015. p. 73-104.

ARANTES, Rogério Bastos. Ministério Público e Política no Brasil. São Paulo: Sumaré, 2002.

ARANTES, Rogério Bastos. Ministério Público na fronteira entre a Justiça e a Política. Justitia, São Paulo, v. 64, n. 197, p. 325-335, dez. 2007.

BANASZAK, Lee Ann. The women's movement inside and outside the State. New York: Cambridge University Press, 2010. 
BECKER, Howard S. Tricks of the trade. Chicago: University of Chicago Press, 1998.

BERMANN, Célio. O projeto da usina hidrelétrica Belo Monte: a autocracia energética como paradigma. Novos Cadernos NAEA, Belém, v. 15, n. 1, p. 5-23, jun. 2012.

BINDER, Amy J. Contentious Curricula: Afrocentrism and creationism in American public schools. Princeton: Princeton University Press, 2002. CASTILHO, Sérgio; LIMA, Antônio Carlos Souza; TEIXEIRA, Carla C. (Orgs). Antropologia das práticas de poder: reflexões etnográficas entre burocratas, elites e corporações. Rio de Janeiro: Contra Capa, 2014.

COSLOVSKY, Salo. Compliance and competitiveness: How prosecutors enforce labor and environmental laws and promote economic development in Brazil. Doctoral Dissertation. Massachusetts Institute of Technology, Massachusetts, 2009.

COSLOVSKY, Salo. Relational regulation in the Brazilian Ministério Publico: the organizational basis of regulatory responsiveness. Regulation and Governance, v. 5, n. 1, p. 70-89, Mar. 2011.

CRAWFORD, Colin. Defending public prosecutors and defining Brazil's (environmental) "public interest”: a review of Lesley McAllister’s "Making law matter: environmental protection and legal institutions in Brazil”. The George Washington International Law Review, v. 40, n. 3, p. 619-647, jan. 2008.

DÓRIA, Pedro. Energia no Brasil e dilemas do desenvolvimento: a crise mundial e o futuro. Petrópolis: Vozes, 1976.

EISENSTEIN, Hester. Femocrats, official feminism, and the uses of power: a case study of EEO implementation in New South Wales, Australia. Yale Journal of Law \& Feminism, v. 2, n. 1, p. 51-73, 1989.

FILLIEULE, Olivier. Some elements of an interactionist approach to political disengagement. Social Movement Studies, v. 9, n. 1, p. 1-15, 2010. 
GAGNE, Patricia. Identity, strategy, and feminist politics. Social Problems, v. 43, n. 1, p. 77-93, Feb. 1996.

GAMSON, William. Commitment and agency in social movements. Sociological Forum, v. 6, n. 1, p. 27-50, mar. 1991.

HIRSCH, Eric. Sacrifice for the Cause: Group processes, recruitment, and commitment in a student social movement. American Sociological Review, v. 55, n. 2, p. 243-254, apr. 1990.

HOOGHE, Liesbet. Supranational activists or intergovernmental agents? Explaining the orientations of senior commission officials toward European integration. Comparative Political Studies, v. 32, n. 4, p. 435-463, Jan. 1999. HYSING, Erik; OLSSON, Jan. Green inside activism for sustainable development: political agency and institutional change. Palgrave: Macmillan, 2017. INGOLD, Karin; VARONE, Frédéric. Treating policy brokers seriously: evidence from the climate policy. Journal of Public Administration Research and Theory, v. 22, n. 2, p. 319-346. Apr. 2012.

JEROLMACK, Colin; KHAN, Shamus. Talk is cheap: ethnography and the attitudinal fallacy. Sociological Methods and Research, v. 43, n. 2, p. 178-209, May 2014.

KATZENSTEIN, Mary Fainsod. Faithful and fearless: moving feminist protest inside the church and military. Princeton: Princeton University Press, 1998.

KELLY, James. Bureaucratic activism and the Charter of Rights and Freedoms: the Department of Justice and its entry into the centre of government. Canadian Public Administration, v. 42, n. 4, p. 476-511, 1999.

KERCHE, Fábio. Autonomia e discricionariedade do Ministério Público no Brasil. Dados - Revista de Ciências Sociais, Rio de Janeiro, v. 50, n. 2, p. 259-279, 2007.

LEMGRUBER, Julita et al. Ministério Público: Guardião da Democracia Brasileira? Rio de Janeiro: Centro de Estudos de Segurança e Cidadania, 2016. 
LOSEKANN, Cristiana. Mobilização do Direito como Repertório de Ação Coletiva e Crítica Institucional no Campo Ambiental Brasileiro. Dados Revista de Ciências Sociais, v. 56, n. 2, p. 311-349, 2013.

MAGALHÃES, Sônia; HERNANDEZ, Francisco (org.). Painel de especialistas. Análise crítica do estudo de impacto ambiental do aproveitamento hidrelétrico de Belo Monte, 29 out., Belém, 2009.

MCADAM, Doug; TARROW, Sidney; TILLY, Charles. Dynamics of contention. Cambridge: Cambridge University Press, 2001.

MCCANN, Michael W. Rights at work: pay equity reform and the politics of legal mobilization. Chicago: University of Chicago Press, 1994.

MELUCCI, Alberto. Nomads of the present: social movements and individual needs in contemporary society. Philadelphia: Temple University Press, 1989. MEYERSON, Debra E.; SCULLY, Maureen A. Tempered radicalism and the politics of ambivalence and change. Organization Science, v. 6, n. 5, p. 585-600, Sep./Oct. 1995.

BRASIL. Ministério Público Federal. Procuradoria da República no Pará. Processo Caso Belo Monte. Tabela de acompanhamento dos processos judiciais do Ministério Público Federal contra irregularidades no projeto e construção da usina hidrelétrica de Belo Monte, no Pará. Belém, PA, mar. 2016. Disponível em: http://www.mpf.mp.br/pa/sala-de-imprensa/ documentos/2016/tabela_de_acompanhamento_belo_monte_atualizada_ mar_2016.pdf/view. Acesso em: 12 abr. 2017.

MISCHE, Ann. Partisan publics: Communication and contention across Brazilian youth activist networks. New Jersey: Princeton University Press, 2008. OBERFIELD, Zachary. Becoming bureaucrats: socialization at the front lines of government service. Philadelphia: University of Pennsylvania Press, 2014. O'LEARY, Rosemary. The ethics of dissent: managing guerrilla government. Los Angeles: Sage, 2014. 
PAUL, Gustavo. Os meninos superpoderosos. Exame, Rio de Janeiro, 31 mai. 2007. Disponível em: http://www.acendebrasil.com.br/media/ imprensa/2007_05_31_Revista\%20Exame.pdf. Acesso em: 01 mai. 2017. PEREIRA, Ana. A construção de capacidade estatal por redes transversais: o caso de Belo Monte. Tese (Doutorado em Ciência Política) - Instituto de Ciência Política, Universidade de Brasília, Brasília, 2014.

PETTINICCHIO, David. Institutional activism: reconsidering the insider/ outsider dichotomy. Sociology Compass, v. 6, n. 6, p. 499-510, Jun. 2012. PUGH, Alison J. What good are interviews for thinking about culture? Demystifying interpretive analysis. American Journal of Cultural Sociology, v. 1, n. 1, p. 42-68, 2013.

RAEBURN, Nicole. Inside out: the struggle for lesbian, gay and bisexual rights in the workplace. Minneapolis, MN: University of Minnesota Press, 2004.

RICH, Jessica. Grassroots bureaucracy: intergovernmental relations and popular mobilization in Brazil's AIDS policy sector. Latin American Politics and Society, v. 55, n. 2, p. 1-25, 2013.

SABATIER, Paul. The advocacy coalition framework: revisions and relevance for Europe. Journal of European Public Policy, v. 5, n. 1, p. 98-130, 1998.

SANTORO, Wayne A.; MCGUIRE, Gail M. Social movement insiders: the impact of institutional activists on affirmative action and comparable worth policies. Social Problems, v. 44, n. 4, p. 503-519, nov. 1997.

SCULLY, Maureen; SEGAL, Amy. Passion with an umbrella: grassroots activists in the workplace. Research in the Sociology of Organizations, v. 19, p. 125-168, 2002.

SILVA, Cátia. Promotores de justiça e novas formas de atuação em defesa de interesses sociais e coletivos. Revista Brasileira de Ciências Sociais, v. 16, n. 45, p. 127-144, 2001. 
SILVA, Marcelo; RUKOWSKI, Bianca. Condições e mecanismos do engajamento militante: um modelo de análise. Revista Brasileira de Ciência Política, n. 21, p. 187-226, 2016.

TAYLOR, Steven J; BOGDAN, Robert; DEVAULT, Marjorie. Introduction to qualitative research methods. New Jersey: John Wiley \& Sons, 1998. WEBER, Max. Economy and society: an outline of interpretive sociology. Translated by G. Roth. Berkeley: University of California Press, 1978. WEISS, Robert. Learning from strangers: the art and method of qualitative interview studies. New York: Free Press, 1995.

ZEMANS, Frances Kahn. Legal mobilization: the neglected role of the law in the political system. American Political Science Review, v. 77, n. 3, p. 690-703, 1983. 


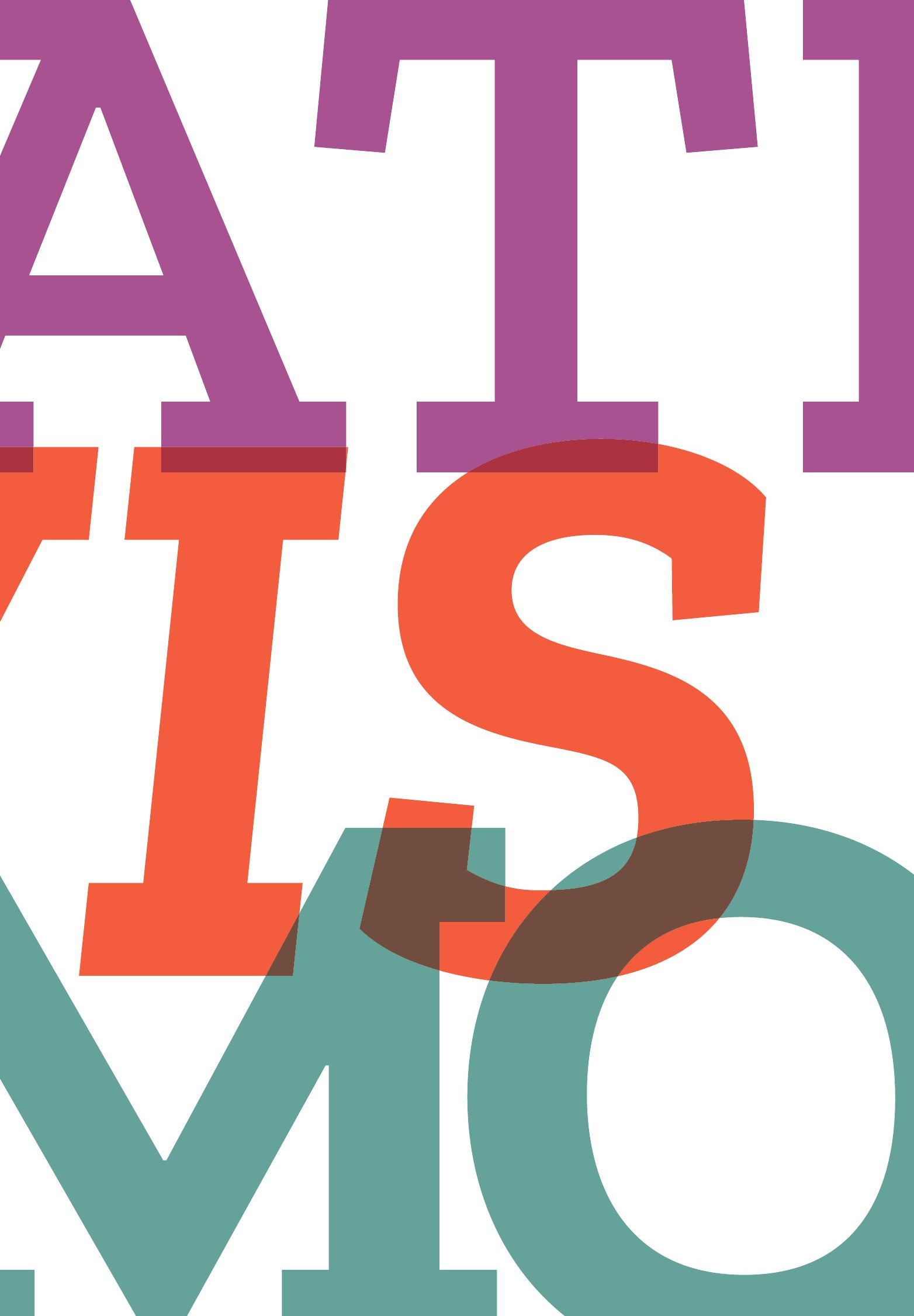




\section{Capítulo 5}

\section{Ativismo institucional em empreendimentos de infraestrutura: autonomia e discricionariedade no caso da Hidrelétrica Belo Monte}

Ana Karine Pereira

\section{Introdução}

Perspectivas sobre a lógica de atuação e o papel dos burocratas têm evoluído no campo das análises de políticas públicas, no sentido de discutir como atores estatais incorporam às suas rotinas institucionalizadas práticas de contestação política. Nesse contexto, a visão weberiana de um burocrata subordinado aos interesses dos políticos, neutro do ponto de vista ideológico, insulado dos interesses sociais e cujo principal instrumento é a técnica, tem sido questionada por abordagens em que o burocrata é visto 
como um ator que "faz política”, moldando as características da política pública (LIPSKY, 1980; LOTTA, 2014). A literatura sobre ativismo institucional intensifica esse debate ao analisar casos de militância política dentro da estrutura estatal, descrevendo o burocrata como um ator pautado por valores específicos. Desse modo, o burocrata passa a ser interpretado como um ator engajado em ações cujo objetivo é defender projetos políticos ou sociais entendidos como de natureza pública ou coletiva (ABERS, 2015). O fator que motiva a militância do burocrata pode estar relacionado à participação direta em movimentos sociais ou pode ser proveniente de compromissos individualizados, construídos a partir de trajetórias e vivências particulares (ABERS, 2015).

Esse novo olhar sobre a burocracia tem sido acompanhado pela necessidade de um aprofundamento do entendimento sobre os fatores que conferem maior liberdade à atuação do burocrata e os empoderam como atores capazes de influenciar o processo decisório de políticas públicas. Nesse enquadramento, os conceitos de discricionariedade e autonomia têm ganhado destaque. Enquanto o primeiro termo é associado à liberdade negativa e à possibilidade de ação dentro de uma estrutura de constrangimentos (ABERS; SANTIAGO, 2017; LOTTA; SANTIAGO, 2017); o segundo está relacionado à ideia de poder e de influência no processo político (ABERS; SANTIAGO, 2017; CARPENTER, 2001).

Este capítulo pretende contribuir para essa discussão ao analisar o que condiciona a ação dos burocratas em um contexto de mobilização e contestação política. Pretende-se explorar quais os efeitos da combinação de discricionariedade e autonomia burocrática na defesa de projetos políticos contenciosos por burocratas estatais. Mais especificamente, este texto tem como foco o ativismo realizado por analistas ambientais, no âmbito do licenciamento ambiental da usina de Belo Monte (BM), para a inclusão de demandas sociais no projeto da hidrelétrica. A partir das análises sobre autonomia e discricionariedade desses atores, é investigado o porquê desse ativismo ser assimétrico e concentrado. Assim, apesar de intensas e variadas, as mobilizações lideradas pelos técnicos da Diretoria de Licenciamento Ambiental (Dilic) do Instituto Brasileiro do Meio Ambiente e dos Recursos Naturais Renováveis (Ibama) foram centralizadas nas etapas iniciais do licenciamento ambiental e nas ações da diretoria. Além disso, o ativismo se 
desenvolveu de forma irregular na estrutura do Ibama, alcançando apenas a Dilic. Como consequência, essa mobilização dos técnicos ambientais não influenciou de forma significativa as decisões de outros órgãos que atuaram no processo da usina (PEREIRA, 2014).

Os dados apresentados neste capítulo são provenientes do estudo dos 34 primeiros volumes do processo de licenciamento ambiental, e de entrevistas semiestruturadas com 49 atores da burocracia estatal e da sociedade civil. As entrevistas foram realizadas nas cidades de Altamira (PA), Belém (PA) e Brasília (DF) entre os meses de junho de 2012 e julho de 2014.

Além desta introdução, o presente estudo encontra-se dividido em quatro outras seções. A segunda seção apresenta um debate conceitual sobre autonomia e discricionariedade, enfatizando suas diferenciações e efeitos no processo de produção de políticas públicas. A terceira discute a transformação do ativismo social em ativismo institucional no caso da usina de Belo Monte, revelando como demandas e mobilizações sociais foram incorporadas pelos burocratas ambientais. A quarta seção oferece um histórico de ativismo dos analistas ambientais, acionando, para isso, as categorias de discricionariedade e autonomia. A quinta seção resgata as principais conclusões da pesquisa realizada.

\section{Autonomia e discricionariedade: definições e efeitos para a produção de políticas públicas}

A interpretação sobre o papel da burocracia estatal e sua lógica de atuação tem sido permeada pelos debates sobre autonomia e discricionariedade (LOTTA; SANTIAGO, 2017). Esses conceitos ganharam evidência a partir do surgimento de novas perspectivas sobre a burocracia que questionam o modelo weberiano, segundo o qual o burocrata era interpretado como um ator implementador das decisões formuladas na esfera política, executando as decisões políticas como se elas correspondessem às suas próprias conviç̧ões (WEBER, 2004). Assim, novos estudos têm apontado a capacidade do burocrata de "fazer política" ao tomar decisões que afetam - formal ou informalmente - a execução da política pública, como o escopo e público alvo da política em questão (LOTTA, 2014). Apesar dessa nova ênfase, 
predomina ainda certa confusão conceitual em relação aos termos “discricionariedade" e "autonomia”, sendo comum sua utilização como conceitos sinônimos ou intercambiáveis (LOTTA; SANTIAGO, 2017). O objetivo desta seção é apresentar os avanços da literatura em relação à definição e diferenciação desses conceitos.

Os debates sobre discricionariedade burocrática alcançaram especial relevância no âmbito da "burocracia de nível de rua" porque, ao focarem nos burocratas implementadores de serviços públicos ou de aplicação de sanções, destacaram que esses atores possuem liberdade para tomar decisões sobre políticas públicas. Para essa perspectiva, a discricionariedade pode ser entendida como a existência de algum nível de arbitrariedade por parte do burocrata nos limites da lei, representando certa liberdade dentro de constrangimentos (LOTTA; SANTIAGO, 2017). Abers e Santiago (2017, p. 184) associam discricionariedade à ideia de liberdade negativa ao ressaltar que

a discricionariedade não nos diz muito sobre o que o funcionário vai fazer com a liberdade que tem. Trata-se de uma espécie de liberdade negativa, que possibilita ou facilita a ação, mas não determina que haverá ação ou em que sentido ela necessariamente ocorre.

Essa liberdade poderia ser proveniente das características das regras que regulamentam a rotina de trabalho dos burocratas implementadores - ambiguidade, abrangência, lacuna ou excesso de normativas. A possibilidade de tomar decisões sobre políticas públicas também seria consequência da própria natureza do trabalho desses atores: como esses atores atuam entregando serviços e em contato com a população, é comum que eles vivenciem situações de imediatismo e de falta de recursos que acabam fazendo com que eles precisem tomar decisões por conta própria para adaptar a política formulada ao contexto social que eles encontram (LOTTA, 2014; LIPSKY, 1980). Além disso, a atuação desses burocratas é inserida em um contexto de delegação de atividades em que é impossível ao principal monitorar todas as ações dos atores. Nesse cenário, surgem brechas para que o burocrata elabore uma interpretação própria da política formulada (LOTTA, 2014). 
A ideia de autonomia é definida a partir de um forte diálogo com os conceitos de poder, sendo entendida pela corrente neoweberiana como a capacidade de formular objetivos e prioridades políticas mesmo diante da oposição de elites sociais e em contextos econômicos desfavoráveis (SKOCPOL, 1985; SKOCPOL; FINEGOLD, 1992). Para essa abordagem, a autonomia seria fortalecida pelo conhecimento técnico dos burocratas e por sua atuação insulada dos grupos sociais. Carpenter (2001) apresenta uma definição semelhante, ao associar autonomia à capacidade de influência dos burocratas em relação às preferências e agendas de políticos e do público organizado. Para ele, a autonomia dependeria da diferenciação - entendida como a existência de preferências, ideologias e interesses da burocracia que a separaria dos atores políticos e de grupos sociais -, de capacidade técnica e criativa, e de legitimidade política ou de reputação construídas a partir da crença de que os burocratas podem oferecer soluções para problemas e ofertar benefícios de forma única. Abers e Santiago (2017) entendem a autonomia como a capacidade de influenciar o processo decisório, seja a partir do poder de persuadir os tomadores de decisão, seja a partir do poder de tomar decisões próprias. Para elas, a autonomia se refere "não apenas ao potencial de ação, mas a uma capacidade de agir" (ABERS; SANTIAGO, 2017, p. 184). Além dos aspectos individuais que possibilitam a autonomia, alguns autores enfatizam características organizacionais, como a posição ocupada na estrutura de poder da organização e o escopo e relevância das atribuições (HUPE, 2013; BATEY; LEWIS, 1982).

Não há consenso em relação aos efeitos da discricionariedade e da autonomia no processo de políticas públicas. Assim, a perspectiva de nível de rua tem enfatizado os efeitos relacionados a adaptações positivas da política a contextos e públicos específicos, produzindo customização e aperfeiçoamento (LOTTA, 2013; LIPSKY, 1980). Por sua vez, a autonomia burocrática em relação à esfera política é interpretada pela corrente neoweberiana como um elemento que pode produzir desvios na agenda governamental e nas políticas oficiais, prejudicando a fiel execução da política conforme ela foi criada (SCOKPOL, 1985). Essa visão disfuncional da autonomia é proveniente da interpretação weberiana de que cabe aos políticos eleitos elaborarem as políticas, e aos burocratas, implementarem-nas. Por outro lado, os neoweberianos avaliam a autonomia em relação aos grupos sociais como um fator positivo para a coerência das políticas públicas, 
ao evitar a captura das burocracias por múltiplos interesses existentes na sociedade. Essa captura levaria à fragmentação e à incoerência da ação estatal (SKOCPOL; FINEGOLD, 1992; EVANS; RUESCHMEYER, 1985). Para Evans (1995), a autonomia deveria ser complementada pela inserção e parcerias com os grupos sociais alvos de certas políticas. Segundo o autor, a "autonomia inserida” aumentaria a inteligência do Estado ao estimular a troca de informações entre atores sociais e burocratas.

Poucos estudos têm ressaltado a relação entre autonomia e discricionariedade e seus efeitos para o processo de políticas públicas. Uma exceção é o estudo de Abers e Santiago (2017) sobre a atuação de burocratas em questões de licenciamento ambiental no Brasil. De acordo com as pesquisadoras, enquanto esses burocratas agem em um contexto de intensa discricionariedade em relação aos pareceres que emitem, eles apresentam baixa autonomia tanto para influenciar as decisões de seus superiores como para exercer as amplas e diversificadas exigências de seu trabalho. A baixa autonomia do burocrata ambiental seria produto de fatores contingenciais da política ambiental, como o alto nível de interferência política e a temporalidade do licenciamento ambiental, que se insere em uma fase tardia do processo decisório de empreendimentos com impactos ambientais.

De forma semelhante, no caso da usina hidrelétrica de Belo Monte, os técnicos da Dilic atuaram com bastante discricionariedade no que diz respeito às suas competências técnicas: a elaboração do Termo de Referência (TR) para guiar os estudos de impacto ambiental; a análise do estudo de impacto ambiental; a elaboração de condicionantes ambientais; a elaboração de pareceres técnicos sobre a viabilidade da usina e sobre o cumprimento das condicionantes. Essa discricionariedade se refere tanto à liberdade para se posicionar em termos técnicos como contrários à aprovação das licenças ambientais, quanto à possibilidade de publicar e expressar essas análises. Entretanto, os técnicos atuaram em um contexto de forte pressão política exercida por outros órgãos e por instâncias superioras ao Ibama. Assim, esse conjunto de pareceres técnicos deu origem ao Relatório de Processo Ambiental, consolidado pela diretoria da Dilic e enviado à Comissão de Aprovação do Licenciamento, composta pelo diretor do Ibama e por diretores do órgão. Os pareceres dos técnicos tiveram pouca influência na decisão final sobre a emissão das licenças, revelando baixa capacidade de influência (ou autonomia) dos técnicos da Dilic em outras esferas do instituto. 


\section{A mobilização em torno da usina de belo monte: a transformação} do ativismo social em estatal

Os debates sobre a usina de Belo Monte remontam à década de 1970 e se inserem na estratégia do governo militar de construir um complexo de hidrelétricas no rio Xingu, como forma de diversificar a matriz energética brasileira em um contexto de crise do petróleo (DÓRIA, 1976). Os primeiros planejamentos de Belo Monte, conhecida naquele momento como Kararaô, ${ }^{1}$ posicionavam a usina como peça fundamental em um conjunto de hidrelétricas que, somadas, gerariam severos impactos sociais e ambientais, como o alagamento de 13 territórios indígenas (TI) e de uma área equivalente a $18.000 \mathrm{~km}^{2}$ (BRASIL, 2010, 2011; JAICHAND; SAMPAIO, 2013). Naquela conjuntura, o primeiro estudo de inventário da bacia do rio Xingu, finalizado em janeiro de 1980, apontava sete locais adequados à implementação de hidrelétricas, destacando a região da Volta Grande do Xingu, em que foram previstos dois aproveitamentos: a usina de Kararaô, que teria uma área alagada de $1.160 \mathrm{~km}^{2}$; e a usina de Babaquara, com área alagada entre 3.940 e $6.140 \mathrm{~km}^{2}$. Em conjunto, as duas usinas teriam uma potência instalada de cerca de 14.000 MW (ANA, 2009). ${ }^{2}$

Os debates em torno da necessidade, dos impactos e da viabilidade de Belo Monte catalisaram diversas mobilizações e desencadearam processos de conflito e de negociação, o que fez com que a usina se tornasse umas das hidrelétricas mais conhecidas do mundo. Por um lado, o governo militar ressaltava a necessidade da construção de grandes usinas hidrelétricas na Amazônia para viabilizar a implementação de diversos projetos desenvolvimentistas que dinamizariam a economia nacional e ajudariam a inserir a região amazônica no espaço produtivo do país (DÓRIA, 1976; LA ROVERE; MENDES, 2000); por outro, a implementação de uma grande usina em uma região com forte presença de populações indígenas, unidades de conservação e com grande biodiversidade alertou ambientalistas nacionais e internacionais, grupos indígenas e organizações de direitos humanos para seus severos impactos.

\footnotetext{
1 O nome da usina foi alterado no final do I Encontro dos Povos Indígenas do Xingu, em 1989.

2 Nota Técnica nº 129/2009/GEREG/SOF/ANA.
} 
Além disso, havia o receio de que as intenções de dinamização da economia e de melhoria da infraestrutura na região do Xingu teriam efeitos inversos, já que a atração de um grande contingente populacional sobrecarregaria a estrutura de serviços básicos da região, como os da área de saúde e educação, que já eram insuficientes para a população local à época. O histórico de atuação do governo federal na Amazônia aumentava esse receio: as hidrelétricas construídas na região nesse período - como Balbina, no rio Uatumã, no estado do Amazonas; e Tucuruí, no rio Tocantins, estado do Pará - foram planejadas e implementadas sem cuidados com questões ambientais e sociais (LA ROVERE; MENDES, 2000); o projeto de colonização da região, na década de 1970, cujo carro chefe foi a construção da rodovia Transamazônica, fracassou e foi abandonado pelo governo federal, deixando os colonos em uma região sem infraestrutura básica (SOUZA, 2006).

O histórico de ativismo em torno da usina hidrelétrica de Belo Monte tem início na década de 1980, sendo caracterizado pelo predomínio de atores da sociedade civil, pela articulação entre atores locais e internacionais e pela confrontação com o Estado. Esse ativismo foi protagonizado por movimentos sociais e por organizações da sociedade civil da região de influência do Xingu que se organizaram, na década de 1970, em resposta à implementação de diversos projetos de desenvolvimento planejados pelos governos militares. Nesse período, organizações foram fortalecidas ou criadas com o objetivo de denunciar a natureza autoritária desses projetos e suas consequências socioambientais (SILVA, 2008; SOUZA, 2006) como, por exemplo, a Prelazia do Xingu e o Conselho Indigenista Missionário (CIMI), ligados à ala progressista da Igreja Católica; também atuaram nessa frente grupos indígenas, a exemplo dos Kayapós; sindicatos rurais; movimentos das mulheres e organizações que defendiam um modelo alternativo de desenvolvimento para a região, como o Movimento pela Sobrevivência da Transamazônica (MPST).

O auge do ativismo contra a usina é representado pelo Primeiro Encontro dos Povos Indígenas do Xingu, em 1989. O encontro é considerado um marco do socioambientalismo brasileiro e foi organizado a partir da forte articulação entre os Kayapós e atores internacionais, como Friends of the Earth e Survival International (FISHER, 1994). O objetivo principal do evento era contestar a construção de um complexo de hidrelétricas 
planejadas para o rio Xingu, mas o escopo do debate acabou sendo ampliado para discutir um modelo de desenvolvimento para a Amazônia brasileira, os problemas ambientais da região e o caráter pouco participativo do processo decisório dos projetos do governo federal para a Amazônia. O evento, que durou uma semana, contou com a participação de 650 índios, 150 jornalistas, 300 ambientalistas, ONGs, representantes da mídia nacional e internacional, além de políticos e burocratas (MCCORMICK, 2011; SOUZA, 2006). Desse último grupo participaram o então presidente da Eletrobras, Antônio Muniz Lopes, o presidente do Ibama, Fernando César Mesquita, o prefeito de Altamira, Armindo Denadin, além de deputados federais.

O Primeiro Encontro dos Povos Indígenas do Xingu teve grande repercussão nacional e internacional. McCormick (2011) revela que, apesar da falta de abertura política por parte do Estado brasileiro no período, essa primeira mobilização foi capaz de dar visibilidade aos impactos que a usina causaria nos povos indígenas, suas consequências sociais e ambientais e os problemas de engenharia do projeto. A movimentação que culminou com o encontro de 1989 tem sido relacionada à suspensão do projeto no final da década de 1980 pelo governo brasileiro. Nas palavras de Carvalho (2006, p. 258):

O período desta aliança entre ambientalistas e indígenas, em um momento de grande visibilidade desses dois grupos e de grande pressão internacional sob o Banco Mundial devido ao seu pobre histórico ambiental, culminou no cancelamento do empréstimo para a Eletronorte.

Belo Monte reaparece na agenda governamental em 1993, quando técnicos do Departamento Nacional de Água e Energia Elétrica (Dnaee) e da Eletrobras se reuniram para analisar o projeto da usina, concluindo que seria necessária uma revisão dos estudos sobre a hidrelétrica para garantir sua viabilidade sociopolítica (MOYA; FRANCO; REZENDE, 2007). Neste sentido, em 1994, a Portaria n ${ }^{\circ} 769$ do Dnaee, determinou a criação de um grupo composto pelo Dnaee, pela Eletrobras e pela Eletronorte com o objetivo de tornar o projeto econômica, social e politicamente viável. Surgiu a proposta de alterar o sítio de barramento, o que minimizaria os impactos ambientais na qualidade da água do rio Bacajá, eliminaria a interferência do reservatório na terra indígena Paquiçamba, e diminuiria a área de inundação do reservatório do 
AHE Belo Monte, ${ }^{3}$ reduzindo os custos com relocações (BRASIL, 2010). Essas alterações foram incorporadas às revisões subsequentes dos estudos de inventário e de viabilidade da usina. ${ }^{4}$ A retomada de Belo Monte na agenda governamental foi formalizada com o lançamento do “Avança Brasil”, plano plurianual referente ao período de 2000 a 2003 que incluía a usina no portfólio dos projetos de infraestrutura (FEARNSIDE, 2002).

As alterações no projeto, interpretadas inicialmente como conquistas da mobilização contrária a usina, logo foram ressignificadas e associadas a novas ameaças. Assim, a redução do reservatório faria com que a potência instalada de produção de energia elétrica de 11,2 mil MW fosse alcançada por apenas três meses ao ano. Isso representaria um grande estímulo para, no futuro, o governo brasileiro investir na construção de outras hidrelétricas no Xingu para garantir a eficiência energética da usina, como era previsto nos planos iniciais da década de 1970 (BERMANN, 2002). O não alagamento de terras indígenas também passou a ser questionado, sendo visto como uma manobra do governo do período para afirmar que grupos indígenas não seriam afetados e, dessa forma, justificar a não realização de oitivas das comunidades indígenas. Além disso, o desvio da maior parte do fluxo de água do rio Xingu, em um trecho de cerca de $100 \mathrm{~km}$ na Volta Grande do Xingu, para uma área de florestas e de assentamentos de agricultores, afetaria diretamente os grupos indígenas Arara e Juruna do Paquiçamba. Esse desvio representaria o maior trecho de vazão reduzida provocado por hidrelétricas no Brasil (MAGALHÃES; HERNANDEZ, 2009). Com a reformulação do projeto, ameaças a outros grupos vulneráveis também começaram a ser evidenciadas, como os efeitos negativos na pesca e na produção agrícola em pequena escala (PEREIRA, 2014).

Nesse contexto, o ativismo contra a usina é retomado, mas em bases diferentes, surgindo uma forte articulação entre atores da sociedade civil e atores estatais, além do deslocamento da mobilização social para o interior de certas burocracias estatais, onde alguns funcionários públicos começaram

3 De acordo com o projeto atual da usina, a área de alagamento é de $516 \mathrm{~km}^{2}$.

4 A revisão do estudo de viabilidade ocorreu no ano de 2002; a atualização dos estudos de inventário, em 2007. 
a defender os interesses e demandas de grupos vulneráveis afetados pela usina. Assim, o embate e a confrontação em relação ao Estado, típicos do ativismo inicial, perde espaço para a realização de parcerias e redes entre atores situados dentro e fora do Estado. Nesse cenário, alguns burocratas (do Ministério Público Federal, do Ibama, da Funai e da Secretaria Geral da Presidência da República) começaram a questionar o projeto da usina e a tentar influenciar as decisões de órgãos da Administração Pública Federal.

A incorporação do ativismo em torno de Belo Monte por atores estatais é facilitada pelas reformas institucionais do período de redemocratização que culminaram em uma reconfiguração da legislação ambiental e do processo decisório de empreendimento com impactos ambientais. Essas legislações atuaram no sentido de fortalecer e ampliar as competências de órgãos estatais responsáveis pela defesa de interesses socioambientais (PEREIRA, 2013). Destarte, em julho de 1985 foi aprovada a Lei $n^{\circ} 7.347$, a Lei de Ação Civil Pública, que possibilita que interesses ambientais, do consumidor e difusos sejam defendidos legalmente. Tal lei aumentou consideravelmente os poderes do Ministério Público de intervir no processo decisório de empreendimentos com impactos ambientais, ao mesmo tempo em que facilitou o encaminhamento de demandas da sociedade civil para a esfera política (COSTA, 2010). Desde então, o órgão tem sido considerado um advogado ambiental e negociador da sociedade (HOCHSTETLER; KECK, 2007; MCALLISTER, 2004, 2008). A Lei $n^{\circ}$ 6.938/1981 criou um sistema nacional, integrado pelo Conselho Nacional do Meio Ambiente (Conama), e uma política nacional para o meio ambiente. Foi introduzida também a necessidade de licenças ambientais e de Estudos de Impacto Ambiental (EIAs) para projetos que causam alterações ecossistêmicas (HOCHSTETLER; KECK, 2007; COSTA, 2010). ${ }^{5}$

Paralelamente à reforma legislativa, ocorreu uma reestruturação dos órgãos com competências na área ambiental. Essa reforma foi impulsionada, no governo Sarney, por pressões internacionais, pelas críticas aos

5 Outras legislações que fortalecem e ampliam as competências de órgãos que atuam na área socioambiental são a Resolução do Conama n. 9/1987; o artigo 231 da Constituição Federal de 1988; e a Lei nº 7804 de 1989. 
projetos desenvolvimentistas e pelo comprometimento do governo com a redução do desmatamento na Amazônia. Assim, no ano de 1989, foi criado o Ibama com status de agência ambiental líder e com a função de coordenar e harmonizar as atividades relacionadas à proteção ambiental, anteriormente fragmentadas em diversos órgãos. Grande parte das novas normativas, que previam um processo decisório mais rigoroso para a aprovação de projetos com impactos ambientais, seria encabeçada pelo Ibama - como a análise de EIAs e a aprovação de licenças ambientais. Formalmente, o órgão representava um papel central no processo decisório de grandes empreendimentos, reportando-se diretamente à Presidência da República e englobando a Secretaria do Meio Ambiente (Sema) e o Conama (HOCHSTETLER; KECK, 2007). Em 1992, com a criação do Ministério do Meio Ambiente, o Ibama passou a ser uma autarquia subordinada ao novo ministério.

Essas reformas representaram o gatilho inicial que possibilitou que alguns burocratas passassem a defender um projeto político alternativo para a região amazônica, permitindo que certos atores localizados dentro do Estado questionassem uma política oficial a fim de defender interesses socioambientais e os direitos de populações vulneráveis. Desse modo, na fase de licenciamento, alguns analistas ambientais passaram a atuar constantemente no processo decisório da usina com o objetivo de defender o interesse de grupos minoritários e de diminuir ou reverter os impactos da usina nessas populações (PEREIRA, 2014). Essa militância ocorreu de forma sobreposta às mobilizações de diversas organizações da sociedade civil local e nacional. Em alguns momentos, é possível perceber uma articulação e certa influência do movimento social na atuação dos analistas ambientais como, por exemplo, o valor dado às manifestações de organizações da sociedade civil em audiências públicas no momento de elaboração de algumas condicionantes da LP; ou os impactos dos alertas da comunidade local sobre o TVR e as consequências sociais da usina na elaboração do Termo de Referência. Esse ativismo foi instrumentalizado, principalmente, a partir da elaboração de pareceres e de notas técnicas que ressaltavam os impactos socioambientais da usina e a impossibilidade de atestar sua viabilidade. Entretanto, esse ativismo foi assimétrico e concentrado nas etapas iniciais do licenciamento ambiental. A aplicação dos debates sobre autonomia e discricionariedade será utilizada, na próxima seção, para analisar essas características da mobilização institucional. 


\section{A atuação do Ibama: autonomia, parcerias e coordenação governamental}

A atuação do Ibama na construção da usina de Belo Monte teve início em 20 de março de 2006, quando a Eletrobras solicitou a abertura do processo de licenciamento ambiental da hidrelétrica junto ao órgão. Assim, a agência foi responsável pela análise e concessão da licença ambiental prévia, em 2010; de instalação, em 2011; e de operação, em 2016. Mais especificamente, dentro do Ibama, a Diretoria de Licenciamento Ambiental (Dilic) possui a competência de analisar os pedidos de licença e, no caso de hidrelétricas, a Coordenação de Energia Hidrelétrica e Transposição (Cohid) possui a atribuição de licenciar esses projetos, no âmbito da Dilic.

O licenciamento de Belo Monte se revelou um grande desafio para o Ibama por causa do grande volume de trabalho, dos prazos curtos, tendo em vista a complexidade do empreendimento, e, principalmente, das pressões sofridas pelo órgão advindas da sociedade civil e do governo. De acordo com um analista entrevistado, Belo Monte “é uma obra de interesse do Estado e de não interesse de vários outros grupos. Então tem pressão de todos os lados” (Brasília, 04/06/2014). ${ }^{6}$ O órgão sofreu pressões do governo para emitir licenças ambientais de forma rápida, o que consiste em uma tarefa difícil em se tratando de empreendimentos de grande complexidade. Por parte da sociedade, grupos sociais tendem a interpretar que o poder de decidir pela implementação do empreendimento se concentra no Ibama, demandando ações da autarquia ambiental. Essa situação acabou estimulando o surgimento de um forte ativismo dentro do Ibama, principalmente a partir de 2009, antes da emissão da licença prévia (LP). Esse ativismo foi motivado, especialmente, por duas questões: $i$ ) as fortes pressões do governo, representado especialmente pelas ações da Casa Civil da Presidência da República, e da Norte Energia, consórcio que possuía a concessão para implantação e operação da usina, que impediram que a agência elaborasse um entendimento aprofundado sobre os reais impactos da usina e sua viabilidade ambiental; ii) a constatação de que os impactos sociais da

6 Entrevista realizada no âmbito da pesquisa de doutorado de Pereira (2014). 
usina seriam extremamente graves, especialmente em uma região carente de serviços e equipamentos sociais básicos.

Como será detalhado nas seções seguintes, esse ativismo foi possibilitado pela discricionariedade dos analistas da Dilic, permitindo que esses atores reinterpretassem regras e ampliassem suas competências, atuando em intensa parceria com a sociedade civil e com outros atores governamentais. Não obstante, as iniciativas e as propostas que surgiram a partir desse ativismo foram limitadas por causa da baixa autonomia desses atores.

\subsection{A discricionariedade como condição do ativismo}

A discricionariedade dos analistas ambientas é proveniente, em grande medida, das características das normativas que regulam o setor ambiental. Nesse sentido, a falta de regulamentação e de definição de "viabilidade ambiental” permitiu que os burocratas do Ibama responsáveis pelo projeto de Belo Monte atuassem além das questões ambientais, incluindo também ações com o objetivo de mitigar ou impedir impactos sociais. Além disso, a pouca precisão dessas normativas ambientais possibilitou que analistas assumissem o papel de coordenadores de múltiplos atores - sociais e estatais - em torno da defesa de melhoria das condições sociais da região do Xingu.

De acordo com a Instrução Normativa n ${ }^{\circ} 184$ de $2008^{7}$ do Ibama, a autarquia ambiental atua dentro do processo de licenciamento: de um lado, como órgão responsável pela análise da viabilidade ambiental do empreendimento e, de outro, como agente condutor e coordenador de um processo que abarca diversos órgãos estatais, cada qual com sua competência. Ademais, a articulação do Ibama com vários órgãos estatais aparece como uma previsão do modelo de licenciamento ambiental regulamentado pela resolução nº 237 de 1997 do Conama. Nesse sentido, o artigo IV dessa resolução determina que:

7 Esta instrução organiza os procedimentos de licenciamento ambiental federal a partir da consolidação das normativas ambientais existentes. 
O Ibama fará o licenciamento de que trata este artigo após considerar o exame técnico procedido pelos órgãos ambientais dos Estados e Municípios em que se localizar a atividade ou empreendimento, bem como, quando couber, o parecer dos demais órgãos competentes da União, dos Estados, do Distrito Federal e dos Municípios, envolvidos no procedimento de licenciamento. (BRASIL, 1997).

A Instrução Normativa no 184 de 2008 prevê os momentos em que os "órgãos intervenientes" no processo de licenciamento devem atuar: no âmbito das discussões do Termo de Referência, ${ }^{8}$ do Estudo de Impacto Ambiental/Relatório de Impacto Ambiental (EIA-Rima) e antes da emissão da licença de instalação (LI). Entretanto, essas normativas não regulamentam como a coordenação entre Ibama e agências estatais deve ocorrer na prática no licenciamento ambiental. Assim, não são estabelecidos quais órgãos devem ser consultados nem o formato dessa interação, o que confere certa liberdade para os analistas ambientais definirem esses aspectos. De acordo com os entrevistados, no caso específico de BM, os analistas ambientais fizeram um esforço atípico para incluir um número variado de órgãos estatais, criando múltiplos momentos de diálogo. Com isso, órgãos que antes nunca haviam interagido no licenciamento ambiental tiveram participação garantida, a exemplo da inclusão do Ministério das Cidades para contribuir com a discussão sobre o reassentamento urbano.

Assim que o licenciamento foi iniciado, os analistas do Ibama convidaram várias agências estatais - como a Fundação Nacional do Índio (Funai), o Instituto do Patrimônio Histórico e Artístico Nacional (Iphan) e a Agência Nacional de Águas (ANA) - para a realização de vistorias na região de implementação do empreendimento e para participar de reuniões públicas com a comunidade a fim de colher subsídios para a elaboração do Termo de Referência. O envolvimento dessa grande diversidade de atores foi crucial para que a equipe técnica começasse a entender os principais impactos da obra como, por exemplo, o efeito da usina na população de

8 O TR é um documento que deve nortear a elaboração dos estudos ambientais de responsabilidade do empreendedor. 
peixes e os impactos no trecho de vazão reduzida (TVR). O TR estabeleceu diretrizes importantes que, inclusive, fizeram com que o empreendedor realizasse uma alteração importante no projeto de viabilidade de 2002, relacionada às vazões do TVR.

A interação entre diversos órgãos estatais foi intensificada mais uma vez no momento de análise do EIA-Rima, a partir de 2009, quando o Ibama solicitou a contribuição de várias instituições para que os estudos ambientais fossem abordados a partir de diversos pontos de vista relacionados com as competências desses órgãos. Dessa forma, o Instituto Chico Mendes de Conservação e Biodiversidade (ICMBio) deveria contribuir com a análise do EIA-Rima a partir de um olhar sobre as unidades de conservação; o Iphan deveria dar atenção ao patrimônio arqueológico; a Funai estudaria os documentos enfatizando os impactos em comunidades indígenas; a Secretaria de Vigilância Sanitária do Ministério da Saúde daria enfoque à relação entre a construção da hidrelétrica e a proliferação de vetores da malária. Já nesse momento, há uma articulação com burocratas da ANA, que enviaram sugestões sobre as vazões a serem mantidas no TVR.

No final de 2009, alguns meses antes da emissão da LP, uma grande variedade de órgãos estatais emitiu pareceres ao Ibama, apontando a viabilidade do empreendimento em relação às suas áreas de competência, mas estabelecendo condicionantes e recomendações que deveriam ser observadas pelo empreendedor. Essas condicionantes foram incluídas pelos analistas do Ibama nas condicionantes da LP.

De acordo com analistas ambientais entrevistados, ainda no período anterior à concessão da LP, a análise do EIA já deixara claro que a fragilidade social da região se mostrava como um impasse para a aprovação da LP. Exemplo disso é a situação precária da educação: alguns municípios afetados pela obra possuíam média de escolaridade de apenas dois anos, o que implicava em enormes dificuldades para capacitar e aproveitar a mão de obra local nos trabalhos ofertados na construção da usina. Segundo os entrevistados, essa situação criou um desconforto entre os analistas porque a falta de estrutura na região se revelava um grave problema, mas não poderia ser alegada como motivo para negação da LP: 
As nossas preocupações, se você olhar as conclusões dos pareceres técnicos da equipe, vai falar sempre dessa complexidade de tratar apenas nossa parte. Porque, de fato, a gente não pode extrapolar a nossa competência, que é atestar a viabilidade do empreendimento. E eu não posso dizer que o empreendimento é inviável porque a prefeitura não tem condições de arcar com médico no hospital. Não cabe a gente chegar a esse ponto. Mas neste caso é tão extremo... o impacto maior da área de socioeconomia que seria o afluxo populacional tão grande em uma região tão carente de segurança, educação, alimentação, habitação. (Brasília, 09/05/2014).

Nesse contexto, seria extremamente difícil para o empreendedor preparar a região para receber uma obra do porte de BM sem a ajuda do governo federal. De acordo com os entrevistados, uma das estratégias dos analistas do Ibama foi adotar uma postura política a fim de defender, dentro do governo federal - mais especificamente, junto ao Ministério do Meio Ambiente e a Casa Civil, que realizava a gestão dos projetos do Programa de Aceleração do Crescimento (PAC) -, a retomada e o aceleramento da implementação do Plano de Desenvolvimento Regional Sustentável do Xingu (PDRS-X). Os debates iniciais sobre o plano remontam aos anos de 2003 e 2004, no início da gestão do ex-presidente Lula. Entretanto, em 2009, a mobilização em torno do plano começava a perder força. De acordo com um entrevistado da Casa Civil (Brasília, 14/05/2014), os debates iniciais em relação ao plano elencavam como eixo condutor o objetivo de produzir desenvolvimento regional a partir da implementação de projetos sociais e ambientalmente sustentáveis, paralelamente à instalação da Usina Hidrelétrica de Belo Monte.

No período que antecede a aprovação da LP, diversos pareceres (como o Parecer $n^{\circ}$ 06/2010, de 26 de janeiro de 2010) dos analistas do Ibama ressaltavam a importância da implementação do PDRS- X, reforçando os esforços do setor elétrico e da Casa Civil para concretizar o plano. Como resultado, nessa mesma época, a Casa Civil e o setor elétrico iniciaram as primeiras ações para efetivamente implementar o plano, como 
a criação do Grupo de Trabalho Intergovernamental que tinha a missão de finalizar o projeto do PDRS-X.

Outra estratégia dos analistas do Ibama para enfrentar os possíveis impactos sociais da usina foi o estabelecimento de condicionantes denominadas “ações antecipatórias” (condicionantes de número 2.10 e 2.11 da LP), que previam medidas ligadas à infraestrutura e que deveriam ser implementadas pelo empreendedor antes do início das obras com o intuito de preparar a região para receber BM. Nesse mesmo contexto, foi inserida uma condicionante na LP relacionada ao TVR, resultado do trabalho conjunto entre analistas do Ibama e da ANA. Em decorrência disso, foi determinado que, nos primeiros anos de operação da usina, seria utilizado um hidrograma conservador.

Os meses anteriores à emissão da licença de instalação (LI) repetem o mesmo movimento ocorrido no período anterior a LP: uma intensa consulta e manifestação de órgãos variados quanto à emissão da nova licença. Como exemplo, em novembro de 2010, o Departamento de Produção Mineral do Ministério do Meio Ambiente declarou não haver óbices para a continuidade do licenciamento ambiental, mas exigiu a elaboração de um “programa de salvamento do patrimônio paleontológico” para ser executado durante a construção da usina. No mesmo período, o ICMBio encaminhou informações para o Ibama que tratavam da indicação de uma área para a criação de uma Unidade de Conservação. Em janeiro de 2011, o Iphan elencou uma série de condicionantes para a emissão da LI. No mesmo mês, a Funai afirmou não haver empecilhos para a emissão da licença de instalação das obras iniciais de BM, desde que as condicionantes tivessem sido garantidas.

Os analistas do Ibama também assumiram um papel de forte articulação e de "negociador" com atores da sociedade civil, extrapolando a previsão da legislação ambiental brasileira de que a interação, no âmbito do licenciamento ambiental, ocorreria via audiências públicas organizadas pela agência ambiental. Dessa forma, uma das primeiras ações do órgão ambiental após o início do licenciamento foi convidar a sociedade civil para reuniões públicas com o objetivo de informar a população sobre o licenciamento de BM e de colher subsídios para a elaboração do Termo de Referência.

A interação formal com a sociedade civil no processo decisório de BM ocorreu por meio de audiências públicas em novembro de 2009. 
Essas audiências aconteceram no âmbito do processo de licenciamento ambiental, tendo o objetivo de apresentar e discutir o EIA-Rima do projeto de Belo Monte, como previsto pela resolução nº 9/87 do Conama. Todavia, a equipe do Ibama não conseguiu finalizar a análise das sugestões e críticas provenientes das audiências, já que um memorando do presidente do Ibama solicitou que os técnicos interrompessem as análises referentes à LP devido aos prazos para a aprovação da licença. Assim, não houve nenhum tipo de sistematização do debate e das questões colocadas durante as audiências. Soma-se a isso a declaração dos técnicos do Ibama, expressas no Parecer Técnico $n^{0} 114 / 2009$, de que, devido aos prazos estipulados pela Presidência, os técnicos não haviam analisado "com profundidade” as contribuições das audiências públicas para a emissão da LP.

Analistas ambientais entrevistados revelam que, apesar disso, muitas questões levantadas foram incorporadas pela equipe técnica do Ibama. Por exemplo, a necessidade de qualificar a mão de obra para ser aproveitada na construção da usina foi algo que surgiu nas audiências e se transformou em uma das condicionantes da LP.

Os técnicos do Ibama também afirmam que a preocupação do órgão com a falta de infraestrutura na região do Xingu para receber BM surgiu, em parte, a partir de demandas expressas pela sociedade nas audiências públicas. A Nota Executiva n ${ }^{\circ}$ 001/2010 da Cohid/Cgene/Dilic/Ibama revela que:

Dentre as manifestações mais contundentes levantadas pela comunidade local na ocasião das audiências públicas foram as questões sobre a infraestrutura das cidades que receberão os maiores contingentes populacionais porventura da construção da UHE Belo Monte. Estas questões se basearam na necessidade de incremento nos sistemas de saúde, educação, saneamento básico, moradia e mobilidade urbana, que, considerando o estágio atual de Altamira/PA, por exemplo, não atendem à população local [...]. A migração de trabalhadores e suas famílias para preenchimento das vagas abertas por ocasião da construção da usina tornará a cidade de Altamira caótica e com pouca capacidade de suporte, potencializando os conflitos socioeconômicos. (IBAMA, 2010a, p. 15). 
Essa demanda foi um dos fatores que levou analistas do Ibama a incluírem a condicionante 2.10, em que são estabelecidas "ações antecipatórias” à implantação da usina, obrigando o empreendedor a investir, de acordo com a nota citada, em "realocação e readequação urbana com a construção de moradias adequadas, de alvenaria, com sistema de drenagem pluvial, esgotamento sanitário e vias pavimentadas” (IBAMA, 2010, p. 1). Foi estabelecido, ainda, que o empreendedor deveria financiar um sistema de saneamento básico que proporcionasse 100\% de tratamento de água e de esgoto para a toda a cidade de Altamira.

Além dessas interações de caráter mais institucional entre analistas ambientais e grupos da sociedade civil, ocorreram encontros informais, como a reunião entre grupos indígenas e o Ibama, no dia 14 de setembro de 2009, na Casa do Índio, em Altamira. Ademais, durante a primeira etapa do processo de licenciamento ambiental, foi bastante comum a visita e a realização de reuniões entre atores centrais na mobilização contra e a favor da usina - como o Fort Xingu e o Instituto Socioambiental (ISA) - e técnicos do Ibama.

Apesar da falta de sistematização e de formalização das diversas demandas e contribuições resultantes das interações constantes com a sociedade civil, a Nota Técnica n ${ }^{0} 7$ GAB/PRESI/Ibama, do dia 27 de novembro de 2009, avalia o conteúdo dos principais documentos gerados pela sociedade civil com potencial de indicação de políticas públicas e condicionantes de licença ambiental. O objetivo era prover a Dilic com elementos adicionais para a análise final das condicionantes necessárias à emissão da LP. Foram analisadas, principalmente, as contribuições do Painel de Especialistas - entregues aos analistas do Ibama na ocasião das audiências públicas - e o Requerimento dos Movimentos Sociais do Xingu e da Transamazônica.

Como resultado, algumas demandas e contribuições foram classificadas como condicionantes potenciais para serem incluídas na LP. Por exemplo, a adoção do hidrograma ecológico, os programas de controle físico do regime migratório da fauna e flora aquáticas, as ações de controle físico do regime migratório de espécies exóticas, os projetos de capacitação e de regularização para a atividade extrativista de peixes ornamentais na área de influência direta do projeto, entre outras. 


\subsection{A baixa autonomia como elemento limitador do ativismo}

A atuação dos analistas do Ibama no processo de Belo Monte é marcada por baixos níveis de autonomia, o que é explicitado pela incapacidade desses burocratas de influenciar questões centrais do processo decisório e de implementação da usina. Essa incapacidade é acompanhada pela constante interferência política nas decisões e atividades dos analistas ambientais. Assim, no contexto de análise da LP, em janeiro de 2010, foi realizada uma reunião entre Ibama, Eletrobras e Casa Civil, em que foram acordados prazos para a finalização da análise ambiental a fim de conceder a LP. Como resultado, os técnicos da Dilic criaram, no mesmo dia, um grupo de trabalho executivo composto por seis servidores a fim de realizar uma análise conclusiva, até o dia 18 de janeiro, de todos os documentos complementares enviados pela Eletrobras para embasar a licença ambiental, como o relatório complementar referente ao hidrograma ecológico e a qualidade da água.

Um dos desdobramentos da atuação desse grupo foi a publicação pela Dilic do Parecer $n^{\circ} 06$ de 2010, no dia 26 de janeiro de 2010, cujo objetivo era analisar a viabilidade da usina. Os técnicos concluíram que os estudos ambientais estavam completos, mas apontaram algumas deficiências no projeto da usina, como a existência de contradições sobre a entrega de energia produzida por Belo Monte ao Sistema Interligado Nacional. Já no dia 28 de janeiro de 2010, o Despacho n ${ }^{\circ}$ 05/2010 da Cohid aponta pendências para a emissão da LP. Soma-se a isso a Nota técnica $n^{\circ}$ 04/2010, que afirma não haver elementos suficientes para atestar a viabilidade ambiental do empreendimento até que sejam equacionadas as pendências apontadas no Parecer $n^{\circ} 6$ de 2010.

Apesar de esses pareceres indicarem um posicionamento dos técnicos do Ibama de que ainda não era possível emitir uma licença prévia, esta foi concedida pouco tempo depois, no dia primeiro de fevereiro de 2010. A licença foi emitida com validade de 2 anos e foi submetida ao cumprimento das condicionantes estabelecidas, totalizando 6 condicionantes gerais e 40 específicas.

Entrevistas realizadas com analistas ambientais envolvidos no processo de licenciamento de BM confirmam que houve um descompasso entre as análises dos técnicos da Dilic e a decisão pela emissão da LP naquele momento: 
Se você observar os pareceres, a equipe técnica não indicou, não foi favorável nem quanto a LP nem quanto a LI. E acabou... não sei se foi uma divergência, teve um entendimento técnico e nas instâncias superiores se fez outro entendimento, também técnico. São visões técnicas diferentes da maneira de conduzir o processo. Mas os pareceres técnicos da equipe, eles não indicavam [a aprovação da LP]. (Brasília, 04/06/2014).

A concessão da licença, nesse contexto, só foi possível porque a decisão final não é dos técnicos da Dilic. Segundo os entrevistados, antes da emissão da LP, havia um clima tenso entre os técnicos do Ibama pois, de um lado, era preciso analisar uma imensidão de documentos e vários impactos que a obra causaria; de outro, havia muita pressão dentro do Ibama para que a análise fosse concluída rapidamente. Pouco tempo antes da aprovação da LP foi publicado um memorando do presidente do Ibama solicitando que o processo de BM fosse fechado da maneira como se encontrava naquele momento. Posteriormente, os pareceres dos técnicos foram enviados para a diretoria da Dilic, que elaborou o Relatório do Processo Ambiental (RPL), encaminhado, em seguida, para a Comissão de Aprovação de Licenciamento, que possuía a competência de dar a decisão final sobre licenciamentos. Essa comissão é formada pelo presidente do Ibama e por várias diretorias do órgão.

A estratégia dos analistas da Dilic, diante desse cenário, foi o estabelecimento de condicionantes rigorosas que aumentassem a garantia da qualidade social e ambiental do projeto. Exemplo disso é a condicionante 2.1, que, diante da incerteza sobre qual seria a vazão ideal para o TVR, estabeleceu que o empreendedor deveria testar um hidrograma conservador nos primeiros anos de operação da usina e que, apenas depois desse período, seria escolhido o modelo de vazão para o trecho.

A emissão da Licença de Instalação também se insere em um contexto bastante polêmico. No período entre a concessão da LP e da LI, houve intensa fiscalização, e análise, do cumprimento das condicionantes estabelecidas pela LP, que deveriam ser concluídas como requisito para a aprovação da LI. Esse monitoramento foi coordenado pelo Ibama e contou com a atuação de órgãos estatais variados. Em agosto de 2010, por exemplo, 
a Funai enviou um ofício ( $\mathrm{n}^{\circ}$ 557/2010) para o Ibama sobre o andamento das condicionantes indígenas, concluindo que:

Diante do exposto, informamos que a Funai considera que as condicionantes não têm sido cumpridas de maneira satisfatória até o presente momento, comprometendo sua total execução quando da solicitação da próxima licença prevista no licenciamento ambiental, impedindo assim qualquer manifestação favorável da Funai em relação à continuidade do empreendimento. (FUNAI, 2010, fl. 2).

A partir de meados de 2010, os analistas da Dilic começaram a cobrar do empreendedor o cumprimento da condicionante $n^{\circ} 2.10$, estabelecida na LP, que previa a realização de ações antecipatórias de infraestrutura antes do início da implementação da usina. Conforme o acordado na LP, o ganhador do leilão de outorga deveria apresentar, em até 30 dias após a definição do concessionário de geração, a estratégia para garantir que toda infraestrutura prévia necessária fosse efetivamente implantada. Entretanto, até o dia 15 de junho, quase dois meses após a realização do leilão, nenhuma medida por parte do vencedor - a Norte Energia - havia sido tomada.

Uma reunião, ocorrida no dia 31 de agosto de 2010, com a presença da Eletronorte, da Companhia Hidrelétrica do São Francisco (Chesf), da Eletrobras, do Ibama, da Leme Engenharia e da Norte Energia reforça o argumento de que o período entre LP e LI foi marcado pela grande preocupação dos analistas ambientais com o cumprimento das condicionantes. Por um lado, os técnicos do Ibama afirmavam que as condicionantes estavam longe de serem atendidas, além de enfatizarem que as ações antecipatórias deveriam ser finalizadas antes do início das obras. Por outro lado, a Norte Energia e a Eletrobras ressaltavam que a construção do canteiro de obras deveria ser iniciada ainda em 2010, no período de seca da região (que se estende até novembro).

Diante do não cumprimento de diversas condicionantes estabelecidas na LP, a solução encontrada pelo empreendedor foi solicitar a LI apenas para as instalações iniciais do empreendimento, que corresponde à infraestrutura logística para subsidiar a construção da hidrelétrica (como o canteiro de obras, o alojamento, o acesso rodoviário etc.). Entrevistados do Ibama revelaram 
que o empreendedor utilizou o argumento em defesa de uma LI parcial a partir da necessidade de cumprir o cronograma estabelecido pela Aneel.

Entretanto, os técnicos do Ibama julgaram inviável a emissão da licença de instalação parcial naquele momento porque, como explicitado no Parecer $n^{\circ}$ 88/2010, as ações antecipatórias não tinham sido concluídas:

Para o atendimento desta ação antecipatória, o empreendedor deverá, pelo menos antes da emissão da LI das Instalações Iniciais, iniciar a implantação de saneamento em Belo Monte e em Belo Monte do Pontal e, concomitantemente às obras do empreendimento, iniciar as obras de saneamento em Altamira e em Vitória do Xingu. Destaca-se que as obras de saneamento básico incluem o tratamento de água para abastecimento, rede de distribuição de água tratada, coleta e tratamento de esgotos, drenagem urbana, coleta e disposição de resíduos urbanos. (IBAMA, 2010b, fls. 6-7).

Os técnicos do Ibama ressaltavam outras ações antecipatórias importantes que ainda não haviam sido iniciadas, como o Programa de Incentivo à Capacitação Profissional e o Programa de Orientação e Monitoramento da População Migrante. Em relação às 40 condicionantes específicas estabelecidas na LP, apenas 23 foram consideradas como necessárias para a emissão da primeira licença de instalação. Dessas, 21 ainda não tinham sido atendidas na data de elaboração do parecer, no dia cinco de outubro de 2010.

Em complementação ao Parecer $n^{0}$ 88/2010, foi publicado o Parecer $n^{\circ}$ 95/2010, em 20 de outubro de 2010. O novo documento continha uma análise do atendimento às condicionantes da LP e da solicitação da LI para as instalações iniciais do empreendimento de Belo Monte. Nesse momento, ainda restavam 12 condicionantes não atendidas pelo empreendedor, levando os técnicos do Ibama a afirmarem, mais uma vez, que: "em que pesem os avanços realizados, restam condicionantes e ações antecipatórias, necessárias à preparação da região, cujo não atendimento compromete o início da implantação das instalações iniciais. Desta forma, não é recomendada a emissão da LI” (IBAMA, 2010c, fl. 22).

Em 4 de janeiro de 2011, a Norte Energia enviou um documento ao presidente do Ibama em que é realizada uma clara pressão pela aprovação da LI: 
Ressalta-se que, pelas características estratégicas e prioritárias da UHE Belo Monte para manter o equilíbrio entre a oferta e a demanda de energia elétrica no país, a manutenção do cronograma das obras do empreendimento e cumprimento de prazos e acordos estabelecidos no contrato de concessão são imperativos, sob pena de graves riscos ao empreendedor e cumulativamente a sociedade. Assim, solicito a atenção de vossa Excelência, para que a emissão da Licença de Instalação do empreendimento venha ocorrer até 15 de fevereiro de 2011, permitindo a mobilização no mês de março para início efetivo das obras em abril deste ano. (NORTE ENERGIA, 2011, fl. 3.768).

Às vésperas da emissão da primeira LI, os analistas do Ibama publicaram, no dia 21 de janeiro de 2011, a Nota técnica n ${ }^{\circ}$ 08/2011. Dessa vez, foi constatado que uma condicionante não havia sido atendida e 12 condicionantes se enquadravam na categoria "parcialmente atendida” ou "em atendimento”. Algumas condicionantes parcialmente atendidas podem ser classificadas como de extrema importância, como é o caso da condicionante $n^{\circ}$ 2.6, que se referia à elaboração do Plano Básico Ambiental, contendo detalhamento dos planos, programas e projetos socioambientais previstos no EIA e suas complementações. Outros exemplos são as ações nas áreas de saúde, educação e saneamento.

O próximo passo foi o encaminhamento de todos esses pareceres e notas técnicas dos analistas ambientais da Dilic, além do Relatório do Processo de Licenciamento (RPL, produzido pela Dilic), para a Comissão de Avaliação de Licenciamento Ambiental, que deveria decidir sobre a emissão da LI. Apesar de várias condicionantes ainda não terem sido plenamente atendidas e das exigências contidas no próprio RPL da realização de vários ajustes no PBA, a primeira licença de instalação foi aprovada no dia 24 de janeiro de 2011. A licença de instalação para o restante da obra ocorreu no dia primeiro de junho de 2011. 


\section{Considerações finais}

A incorporação do ativismo em torno do projeto da usina de Belo Monte pelos analistas ambientais do Ibama foi condicionada pela discricionariedade e autonomia desses burocratas. Assim, a discricionariedade viabilizou o engajamento com outros atores e a mobilização de ideias, funcionando como um instrumento para que analistas reinterpretassem e ampliassem suas competências e atribuições no âmbito do licenciamento ambiental. Nesse contexto, os analistas assumiram uma posição política de articulação entre atores estatais e da sociedade civil. Essa interação, por sua vez, embasou e alimentou ações de mobilização variadas: forneceu informações para que os técnicos do Ibama defendessem a inclusão de condicionantes não apenas ambientais, mas também sociais, fortaleceu o projeto de retomada do PDRS-X e conferiu suporte para que os analistas ambientais questionassem, por meio de pareceres, a viabilidade da usina.

Essas mobilizações foram concentradas, especialmente, no contexto de aprovação da LP e da LI, alcançando principalmente ações de natureza interna à Dilic. Dessa forma, no âmbito da diretoria, os analistas tiveram liberdade para elaborar e publicar pareceres que questionavam a viabilidade da usina e que denunciavam suas consequências sociais. Também tiveram liberdade para elaborar condicionantes de caráter social, a exemplo das ações antecipatórias. Do mesmo modo, esses burocratas gozaram de discricionariedade para reformular sua lógica de trabalho, atuando como articuladores políticos em torno da defesa de um projeto de contenção dos impactos sociais da usina.

O ativismo desses analistas, entretanto, foi incapaz de alcançar e de influenciar de forma significativa os tomadores de decisão localizados fora da diretoria. Mesmo dentro da estrutura do Ibama, as manifestações e pareceres dos analistas não condicionaram as decisões da Comissão de Aprovação de Licenciamento. Nesse cenário, as ações antecipatórias foram implementadas com severos atrasos, inviabilizando em grande medida sua efetividade de preparar a região para receber a obra. Convém lembrar que as declarações e análises dos analistas da Dilic atestando a inviabilidade da LP e da LI foram desconsideradas.

Essa baixa autonomia dos analistas ambientais em um contexto de intensa discricionariedade é convergente com as análises de Abers e Santiago 
(2017) e reforça os achados das autoras de que estudos sobre autonomia devem considerar não apenas as características individuas dos atores, mas também as contingências da política pública. No caso de Belo Monte, essas restrições institucionais foram marcadas por forte interferência política no Ibama, o que inviabilizou o poder dos analistas da Dilic de influenciarem os tomadores de decisão de instâncias superiores. Assim, a combinação de forte discricionariedade com baixa autonomia produziu um ativismo concentrado e assimétrico, alcançando apenas as fases iniciais do processo de licenciamento ambiental e se limitando, principalmente, às ações da Dilic.

O estudo apresentado neste capítulo evidencia que as características do ambiente institucional das políticas públicas fornecem constrangimentos e também recursos para a ação política. No caso de Belo Monte, a discricionariedade representou uma condição de liberdade negativa que possibilitou a realização de ações criativas e contestatórias. Por outro lado, o contexto político - marcado pela agenda desenvolvimentista, por conflitos entre atores em torno da usina e pela fragilidade da Dilic no âmbito do Ibama e da Administração Pública - culminou em baixa autonomia, limitando os recursos que burocratas puderam acionar para concretizar seus projetos políticos. Por fim, o caso de Belo Monte revela a necessidade de diferenciar os conceitos de autonomia e discricionariedade para que se possa compreender a ação de burocratas (e seus resultados) que engajam em ativismo institucional.

\section{Referências}

ABERS, Rebecca Neaera. Ativismo na burocracia? O médio escalão do programa bolsa verde. In: CAVALCANTE, Pedro Luiz Costa; LOTTA, Gabriela S. (org.). Burocracia de médio escalão: perfil, trajetória e atuação. Brasília: Enap, 2015.

ABERS, Rebecca Neaera; SANTIAGO, Ariadne. A autonomia do burocrata técnico: o caso do licenciamento ambiental do Ibama. In: DE PAULA, Jean Marla P. et al. (org.). Burocracia federal de infraestrutura econômica: reflexões sobre capacidades estatais. Brasília: Ipea, 2017. 
ANA (Agência Nacional De Águas). Nota Técnica nº 129, de 30 de setembro de 2009. Trata das análises técnicas empreendidas pela ANA sobre a Declaração de Reserva de disponibilidade hídrica relativa ao aproveitamento hidrelétrico Belo Monte, a ser implantado no rio Xingu, na bacia hidrográfica do rio Amazonas, formulada pela Agência Nacional de Energia Elétrica. GEREG/SOF/ANA, Brasília, DF, 30 set. 2009.

BATEY, Marjorie V.; LEWIS, Frances M. Clarifying autonomy and accountability in nursing service. The Journal of Nursing Administration, Hagerstown, v. 12, n. 9, p. 13-18, 1982.

BERMANN, Celio. Energia no Brasil: para quê? Para quem? Crise e alternativas para um país sustentável. São Paulo: Editora da Livraria da Física, 2002. BRASIL. Decreto $n^{\circ}$ 7.340, de 21 de outubro de 2010. Institui o Plano de Desenvolvimento Regional Sustentável - PDRS do Xingu, o seu Comitê Gestor e dá outras providências. Diário Oficial da União. Poder Executivo, Brasília, DF, 22 out. 2010. Seção 1, p. 1.

BRASIL. Decreto n 7.577, de 11 de outubro de 2011. Dispõe sobre o remanejamento de cargos em comissão do grupo-direção e assessoramento superiores (DAS) e altera o anexo II ao decreto 7.063, de 13 de janeiro de 2010. Diário Oficial da União. Poder Executivo, Brasília, DF, 13 out. 2011. p. 11. BRASIL. Resolução no 237, de 19 de dezembro de 1997. Dispõe sobre licenciamento ambiental; competência da União, Estados e Municípios; listagem de atividades sujeitas ao licenciamento; Estudos Ambientais, Estudo de Impacto Ambiental e Relatório de Impacto Ambiental. Diário Oficial da União. Ministério do Meio Ambiente, Brasília, DF, 20 dez. 1997. Seção 1, p. 30841-30843.

CARPENTER, Daniel. The forging of bureaucratic autonomy: reputations, networks, and policy innovation in executive agencies, 1862-1928. Princeton, NJ: Princeton University Press, 2001. 
CARVALHO, Georgia. Environmental resistence and the politics of energy development in the Brazilian Amazon. The Journal of Environment Development, v. 15, n. 3, p. 245-268, set. 2006.

COSTA, Agnes. M. Sustainable dam development in Brazil: between global norms and local practices. Bonn: Deutsches Institut für Entwicklungspolitik, 2010.

DÓRIA, Pedro R. Energia no Brasil e dilemas do desenvolvimento: a crise mundial e o futuro. Petrópolis: Vozes, 1976.

EVANS, Peter. Embedded autonomy. Princeton: Princeton University Press, 1995.

EVANS, Peter; RUESCHEMEYER, Dietrich. The state and economic transformation: toward an analysis of the conditions underlying effective intervention. In: EVANS, Peter; RUESCHEMEYER, Dietrich; SKOCPOL, Theda. Bringing the State Back In. New York: Cambridge University Press, 1985.

FEARNSIDE, P. Avança Brasil: environmental and social consequences of Brazil's planned infrastructure in Amazonia. Environmental Management, v. 30, n. 6, p. 735-747, 2002.

FISHER, William. Megadevelopment, environmentalism, and resistence: the institutional context of Kayapó indigenous politics in central Brazil. Human Organization, v. 53, n. 3, p. 220-232, 1994.

FUNAI. Ofício n 557 de 2010, endereçado ao IBAMA. Ministério da Justiça. Brasília, DF, 2010.

HOCHSTETLER, Kathryn; KECK, Margaret E. Greening Brazil: environmental activism in state and society. Durham: Duke University Press, 2007. HUPE, Peter. Dimensions of discretion: specifying the object of street-level bureaucracy research. Der Moderne Staat, v. 6, n. 2, p. 425-440, 2013.

IBAMA. COHID/CGENE/DILIC. Nota Executiva n ${ }^{\circ}$ 001, de 2010. Ministério do Meio Ambiente. Brasília, DF, 2010a. 
IBAMA. COHID/CGENE/DILIC. Parecer nº 88 de 2010. Ministério do Meio Ambiente. Brasília, DF, 2010b.

IBAMA. COHID/CGENE/DILIC. Parecer n ${ }^{\circ} 95$ de 2010. Ministério do Meio Ambiente. Brasília, DF, 2010c.

JAICHAND; Vinodh; SAMPAIO, Alexandre Andrade. Dam and be damned: the adverse impacts of Belo Monte on Indigenous peoples in Brazil. Human Rights Quarterly, v. 35, p. 408-447, 2013.

LA ROVERE, Emilio; MENDES, Francisco. Tucuruí hydro power complex Brazil. Relatório de Pesquisa. World Commission on Dams. Cape Town, 2000.

LIPSKY, Michael. Street-level bureaucracy: dilemmas of the individual in public service. New York: Russell Sage Foundation, 1980.

LOTTA, Gabriela S. Agentes de implementação: uma forma de análise de políticas públicas. Cadernos Gestão Pública e Cidadania, São Paulo, v. 19, n. 65, jul./dez. 2014.

LOTTA, Gabriela S.; SANTIAGO, Ariadne. Autonomia e discricionariedade: matizando conceitos-chave para o estado de burocracia. Revista Brasileira de informação bibliográfica em Ciências Sociais, v. 83, p. 21-41, 2017.

MAGALHÃES, Sônia; HERNANDEZ, Francisco del Moral (org.). Painel de Especialistas. Análise crítica do Estudo de Impacto Ambiental do Aproveitamento Hidrelétrico de Belo Monte. Belém, PA, 29 out. 2009.

MCALLISTER, Lesley K. Making law matter: environment protection and legal institutions in Brazil. Stanford, CA: Stanford University Press, 2008. MCALLISTER, Lesley K. Environmental enforcement and the rule of law in Brazil. Berkeley: University of California, 2004.

MCCORMICK, Sabrina. Damming the Amazon: local movements and transnational struggles over water. Society and Natural Resources, v. 24, p. 34-48, Sep. 2011. 
MOYA, Carlos Alberto; FRANCO, Hélio Costa; REZENDE, Paulo Fernando. AHE Belo Monte: evolução dos estudos. Artigo apresentado no Comitê Brasileiro de Barragens. In: SEMINÁRIO NACIONAL DE BARRAGENS, 27., 3 a 7 jun., Belém/PA, 2007.

NORTE ENERGIA. Processo de licenciamento ambiental AHE Belo Monte, 4 jan. 2011. Consórcio Norte Energia, Eletrobras, Rio de Janeiro, 2011.

PEREIRA, Ana Karine. A construção de capacidades estatais por redes transversais. 2014. 265 f., il. Tese (Doutorado em Ciência Política) - Instituto de Ciência Política, Universidade de Brasília, Brasília, 2014.

PEREIRA, Ana Karine. Desenvolvimentismo, conflito e conciliação de interesses na política de construção de hidrelétricas na Amazônia brasileira. Texto para discussão. Brasília, Rio de Janeiro: Ipea, 2013.

SILVA, Maria Ivonete Coutinho. Mulheres Migrantes da Transamazônica: construção da ocupação e do fazer política. 2008. 374 f., il. Tese (Doutorado em Ciências Sociais) - Centro de Filosofia e Ciências Humanas, Universidade Federal do Pará, Belém, 2008.

SKOCPOL, Theda. Bringing the state back in: strategies of analysis in current research. In: EVANS, Peter; RUESCHEMEYER, Dietrich; SKOCPOL, Theda. Bringing the state back in. Cambridge: Cambridge University Press, 1985.

SKOCPOL, Theda; FINEGOLD, Kenneth. State capacity and economic intervention in the early new deal. Political Science Quarterly, v. 97, n. 2, p. 255-278, 1982.

SOUZA, Ana Paula Santos. O desenvolvimento socioambiental na Transamazônica: a trajetória de um discurso a muitas vozes. 2006. 140 f., il. Dissertação (Mestrado em Agricultura Familiar e Desenvolvimento Sustentável) - Núcleo de Ciências Agrárias e Desenvolvimento Rural, Universidade Federal do Pará, Belém, 2006.

WEBER, Max. Economia e sociedade. Brasília: Editora da UnB, 2004. Volume 2. 


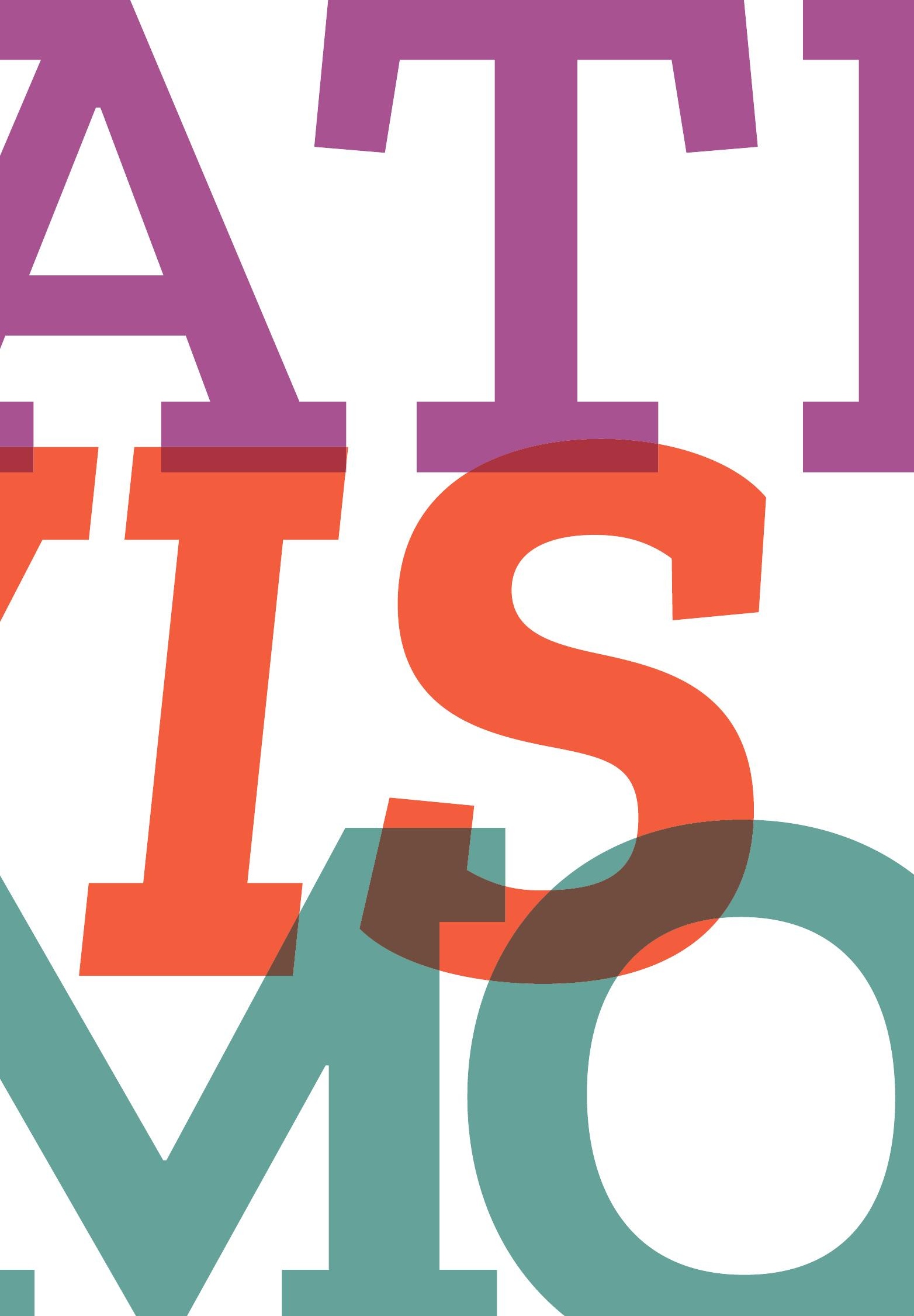




\section{Capítulo 6}

\section{Ativismo e construção de significado: a política de AIDS do governo federal ${ }^{1}$}

Mariana Gomes Cartaxo

\section{Introdução}

Os estudos sobre o Estado estão geralmente voltados para a compreensão dos fenômenos institucionais em seu nível sistêmico, ao direcionar o olhar para a estrutura e para os seus arranjos macro. A dimensão subjetiva dos atores que ocupam as instituições do governo ainda é um território analítico em processo de exploração. A literatura sobre interacionismo simbólico propõe uma expansão da análise da ação social para abarcar a construção de significados e a interação como processos constituintes das instituições humanas (HALLET; VENTRESCA, 2006). Isso implica em observar regras, normas

1 Este capítulo é uma versão retrabalhada de algumas das discussões levantadas em minha dissertação. Para discussões mais aprofundadas de outros temas, ver Cartaxo (2018). 
e processos que guiam as instituições com as pessoas que as aplicam e que também constroem significados sobre o lugar que ocupam.

No Brasil, a consolidação de um Estado heterogêneo (ABERS; SERAFIM; TATAGIBA, 2014) trouxe à tona uma dinâmica peculiar de construção institucional. No âmbito federal, a integração de burocratas no Estado acabou por incorporar uma série de atores provenientes de movimentos sociais nos quadros do funcionalismo público. Para além disso, o processo de concepção das políticas públicas na virada do século foi motivado pela mobilização de diversos grupos sociais, que depois de um longo período ditatorial passaram a ter espaço para suas demandas (MISCHE, 1997; MENICUCCI, 2007). Dessa forma, o contexto histórico local é extremamente significativo para se compreender as instituições e políticas públicas no país.

A política federal de AIDS é um dos exemplos de políticas que surgiram na onda de democratização do Brasil e que tiveram, em sua construção, a presença de diversos atores de movimentos sociais. Desde o início, o desconhecimento sobre a doença e a presença de figuras como o ativista Betinho deram uma carga emocional e simbólica muito forte para a urgência da resposta nacional ao vírus. O processo de incorporação desse problema de saúde pública ao Sistema Único de Saúde (SUS), contando com ajuda internacional e com a participação de ativistas na gestão (RICH, 2013), criou uma política altamente especializada e com uma estrutura forte e independente. Nos dias de hoje, o avanço técnico e científico ajudou a "normalizar" o problema na sociedade, mas não foi suficiente para lidar com esse grande desafio que afeta, segundo levantamento de 2017, 882 mil brasileiros (SVS/DIAHV/BOLETIM EPIDEMIOLÓGICO, 2017). Lidar com os resquícios de um passado nebuloso e enfrentar o futuro é o que movimenta a construção da resposta de vários dos atores alocados em instituições estatais. Nesse processo, muitos significados são criados sobre o papel da instituição em atender demandas contemporâneas.

A resposta do Estado brasileiro à AIDS é construída em sua maioria por gestores técnicos e pela diretoria do atual Departamento de Infecções Sexualmente Transmissíveis, AIDS e Hepatites Virais (Diahv). São esses burocratas os responsáveis por criar as diretrizes da política pública no âmbito federal e trabalhar na coordenação dos recursos para os estados e municípios. Por estarem em contato direto com movimentos sociais, os 
gestores muitas vezes são os responsáveis por traduzir os interesses da sociedade civil em aplicações concretas. Ao atuar nessa ponte, esses indivíduos precisam encontrar formas de aplicar a agenda dentro da estrutura administrativa do Ministério da Saúde.

Levando isso em conta, este capítulo pretende lançar luz sobre certas lacunas no funcionamento do Estado por meio do burocrata na política de AIDS e de suas interpretações sobre o papel da instituição. Partimos do pressuposto de que instituições são habitadas (HALLETT; VENTRESCA, 2006) e que, para compreendê-las, é preciso adentrar o mundo dos atores e captar suas impressões sobre os fenômenos institucionais. Dessa forma, voltamos nosso olhar para os gestores da política de AIDS e procuramos compreender como a origem ativista do órgão expressa e molda as narrativas empregadas por essas pessoas.

Com base em 21 entrevistas e na análise de documentos históricos, observamos os conceitos mobilizados pelos atores ao longo dos anos da política pública. A história ajudou a fundar uma narrativa interna de autonomia e independência organizacional em relação a outros quadros do Ministério da Saúde. Ao examinar as percepções subjetivas em momentos de transformação política, percebemos que, para esses atores, a mobilização dentro do Estado é construída principalmente por meio da socialização dos funcionários e por influência do histórico do departamento.

Partimos de uma mudança organizacional importante - a transformação do programa em departamento em 2009 - para entender as interpretações sobre dois momentos institucionais distintos. Procuramos analisar como as mudanças afetaram a ordem estabelecida, fundada especialmente pela legitimidade informal e por redes consolidadas de autonomia administrativa.

Considera-se que, ao estudar o ativismo como um conceito importante para se compreender os burocratas, a dimensão simbólica é fundamental para observar como as redes sociais e a interação entre os atores possibilitaram a construção de uma narrativa ativista. Para ampliar as possibilidades de compreensão dessa dimensão simbólica da ação, o ativismo também compõe as diferentes narrativas institucionais existentes. Somando-se às diversas pesquisas que trabalham sobre o tema de ativismo institucional no Brasil (VIANA, 2017; SANTIAGO, 2017; BRANDÃO; VIANA, 2016; BRANDÃO; VILAÇA, 2017; OLIVEIRA, 2016; VILAÇA, 2017), este 
capítulo pretende mobilizar a literatura sobre ação e construção de significado para avançar a análise sobre o ativismo dentro do Estado. Dessa forma, espera-se ultimamente ampliar os estudos sobre os atores que participam da gestão governamental, abrindo a "caixa preta do Estado" (ABERS; SERAFIM; TATAGIBA, 2014).

A presente pesquisa está dividida em três seções. Na primeira, apresentamos uma reflexão sobre o estudo da ação e a análise das instituições. Na seção seguinte, descrevemos a política de AIDS, reconstruindo historicamente a sua importância política e dando contexto a sua relativa autonomia institucional. Esclarecemos, ainda, a mudança institucional de programa para departamento e buscamos contextualizá-la dentro de um processo político mais abrangente. Na terceira seção, analisamos as interpretações dos burocratas sobre essa transformação, e como ela mobilizou diferentes interpretações dos gestores sobre o papel do Diahv e a atuação da política de AIDS dentro do Ministério da Saúde. Por fim, oferecemos, junto às considerações finais, algumas possíveis implicações de pesquisa.

\section{Instituições habitadas e a ação}

A agência é um conceito fundamental para se compreender o papel do indivíduo em processos institucionais. Ao utilizar esse conceito, partimos do pressuposto de que as pessoas têm a capacidade de agir sobre o meio de acordo com influências internas e externas. Compreender a construção e a mobilização dessas concepções pessoais é um passo importante para a análise de fenômenos sociais. A agência surge a partir dos conhecimentos do ator sobre as estruturas e de sua habilidade de aplicá-los a outros contextos. Essa possibilidade de mobilizar recursos dentro de um esquema de regras é implícita à ação social (SEWELL, 1992).

As estruturas moldam as configurações da agência por meio de marcadores sociais - tais como renda, gênero, classe, etnia, entre outros - que possam restringir ou possibilitar a ação. Cada característica da estrutura proporciona aos atores um conhecimento diferente acerca dos esquemas e estabelece acessos distintos aos recursos, isto é, "as estruturas e as agências humanas que as dotam são carregadas de diferenças de poder” (SEWELL, 
1992, p. 21, tradução nossa). ${ }^{2}$ A partir da proposta de Sewell, podemos entender como as formas de agir no mundo variam de acordo com as condições dos indivíduos, e como estas modulam suas capacidades e práticas.

Não obstante, o indivíduo, além de estar imerso em arranjos estruturais, também está fadado a viver em sociedade. A construção de relações sociais é um aspecto importante para se compreender a agência humana, e as redes são instrumentos poderoso para a ação. Nesse sentido, Emirbayer e Goodwin (1994) propõem incluir no debate a abordagem relacional, por meio de redes sociais. Essa perspectiva analítica permite a investigação de dimensões que constrangem e habilitam as relações entre os atores sociais dentro de um sistema. Os autores defendem um maior protagonismo das estruturas e dos papéis sociais dos atores.

Para esses teóricos, é preciso reconhecer que a estrutura possui um caráter relacional e que está embasada em arranjos concretos. A autonomia individual não é concebida sozinha, ela se faz possível por meio de várias estruturas e pela formação da identidade. Essa compreensão é importante para enxergar o papel da identidade ${ }^{3}$ e das relações em rede na prática individual dos atores (EMIRBAYER; GOODWIN, 1994).

Em meio ao intenso debate sobre o papel da agência, passou-se a questionar a visão monolítica e distanciada das instituições, onde os estudos institucionalistas focavam intensamente em regras e normas, sem olhar para os processos subjetivos por trás da construção institucional. Questionando essa perspectiva, DiMaggio (1988) defende que a institucionalização deve ser observada como um processo formado por meio da soma de esforços de atores que apoiam, entram em confronto e lutam por uma definição. Dessa forma, as instituições precisam ser reproduzidas constantemente pelos atores, e essa reprodução geralmente é problemática. A ideia de trabalho institucional, posteriormente desenvolvida mais a

2 "Structures, and the human agencies they endow, are laden with differences in power." (SEWELL, 1992, p. 21).

3 A identidade e os seus significados, nessa perspectiva, são uma forma importante de se compreender como uma organização opera a partir das pessoas que a ocupam. As instituições, segundo Hallett e Ventresca (2006, p. 215), “são habitadas por pessoas e suas ações” [“they are 'inhabited' by people and their doings.”] (tradução nossa). 
fundo por Lawrence, Suddaby e Leca (2009), é a de que o trabalho prático dos atores é o que permite que as instituições existam e continuem sendo mobilizadas e transformadas.

A sociabilidade tem implicações claras para as instituições ao influenciar como a burocracia funciona na prática (HALLETT; VENTRESCA, 2006). Hallett e Ventresca extraem dos estudos de Blumer a premissa de que as pessoas agem com base em significados derivados da interação social. Para eles, a ordem social é o resultado de interações dinâmicas ou negociações entre atores. A vida organizacional, deste modo, é produto de um trabalho interativo e constante de construção coletiva de significados sobre a instituição. Compreender os significados é especialmente importante para analisar políticas como a de AIDS, em que um emaranhado de atores de origem governamental e de movimentos sociais consolidaram uma estrutura organizacional bastante peculiar com relação a outras doenças. As redes construídas ao longo do processo de consolidação da política pública formaram sua própria atuação institucional.

A ordem social, para Hallett e Ventresca, é baseada em interações simbólicas entre os atores, e essa dinâmica lhes garante legitimidade informal. Essa legitimidade informal construída pelas redes tem uma forte relação com a atuação dos indivíduos e a autonomia percebida por eles. O conceito de autonomia é constantemente utilizado para descrever aspectos diferentes de uma instituição. Geralmente, buscamos compreender os elementos que possibilitam e facilitam a ação do burocrata e do lugar que ocupa frente às regras impostas. Pensando na construção de significados, nesta pesquisa estamos preocupados em descrever a ideia de autonomia como um debate em aberto entre os gestores e em detalhar como estes mobilizam diferentes conceitos para justificar o efeito das mudanças institucionais em seu trabalho.

Dessa forma, entendemos a questão da autonomia do Diahv como uma “controvérsia”, ${ }^{4}$ porque o tema mobiliza diferentes interpretações acerca do papel da política e de seus posicionamentos. A partir das entrevistas, percebemos

4 Utilizamos o conceito de Viana (2016, p. 16), que entende controvérsia como “diferentes entendimentos e posições por parte dos atores acerca de um problema público, em geral, ancorados em ordens de grandeza ou em racionalidades mais amplas”. 
que as mudanças pelas quais a instituição passou acabaram afetando as percepções sobre autonomia organizacional dos gestores em diferentes níveis.

Pensando nessa construção, a ideia de ativismo se torna especialmente relevante para se compreender quadros de certas políticas públicas. No Brasil, a formação de um Estado heterogêneo (ABERS; SERAFIM; TATAGIBA, 2014) deu espaço para que os movimentos sociais pudessem ocupar cargos na burocracia. Rich (2013) observa que, na política de AIDS brasileira, a formação de burocracias ativistas era bastante marcante. Durante esse processo, as alianças entre burocratas e sociedade civil ajudaram a consolidar o campo no Brasil e a estabelecer as primeiras respostas quando a doença ainda era uma incógnita - do ponto de vista clínico, mas também político e social. Além disso, as alianças com a sociedade civil eram estratégicas por permitir a atuação em lugares onde o Estado não tinha capilaridade suficiente para atuar.

Dentro do Ministério da Saúde, Rich (2013) destaca, ${ }^{5}$ ainda, que diversos ativistas do movimento de AIDS ingressaram na política no nível federal por serem os primeiros especialistas sobre um tema desconhecido. Ao estudar ativismo institucional, defendemos que é preciso voltar o olhar para os atores que, dentro de um ambiente burocrático, exercem sua agência com a intenção de trabalhar sobre uma agenda política. No recorte aqui proposto, voltamo-nos especialmente para as perspectivas do gestor e ao modo como ele cria os significados em diálogo com a história da instituição.

Os atores dentro das instituições são, afinal, os atores responsáveis por implementar e contestar agendas. A partir do diálogo entre diferentes visões, a literatura aqui citada permite observar como essas disputas ${ }^{6}$ se dão em um nível micro (dos atores individuais) e macro (de interesses e decisões mais amplas).

5 A autora nota, além do mais, como esse fenômeno dos ativistas burocratas é comum especialmente na América Latina, percebendo que esses atores tomam posições de liderança dentro da instituição e continuam mobilizando a agenda no Estado.

${ }^{6}$ Isto é, como o contexto acaba por afetar diretamente os atores e suas perspectivas sobre a própria agência. A maneira como o gestor enxerga o seu papel e a instituição em que trabalha é fundamental para compreender a forma como a política pública é organizada e legitimada. 
Transitando entre aspectos externos (estrutura e contexto histórico) e subjetivos (a agência dos gestores), o processo de institucionalização passa por uma mobilização constante dos atores que ocupam o órgão público. A reprodução dos quadros institucionais, feita por meio do trabalho prático dos atores, acontece com base em significados derivados da própria ação social (DIMAGGIO, 1988).

Assim como no trabalho de Gouldner (1954), revisitado por Hallett e Ventresca (2006), pretendemos observar dois momentos institucionais específicos e avaliar as diferentes reações dos envolvidos para extrair as interpretações sobre o papel da instituição. Com base na pesquisa realizada e na esteira de outros autores e autoras, entendemos que a construção da política de AIDS teve uma base ativista que foi determinante na consolidação da política e, dessa forma, a construção de significado para os gestores acabou influenciada por essa perspectiva. Como se verá adiante, por conta do ativismo e da liberdade de trabalho entre as redes hierárquicas consolidadas na instituição, a ideia de autonomia institucional entra em xeque após a mudança.

\section{A política de AIDS do governo federal}

Como ponto de partida, é necessário contextualizar, historicamente, a política de AIDS e como sua origem se entrelaça com a história dos movimentos de luta contra a AIDS no Brasil. Durante o processo de construção da política, há uma relação próxima entre o Estado e os movimentos sociais, além de forte influência de entidades e atores internacionais na consolidação do modelo de resposta nacional.

Em 1981, uma doença pneumática afetando uma série de homens homossexuais foi identificada pelo centro de controle de doenças norte-americano, o Center for Disease Control and Prevention (CDC) (UNAIDS, 2008). Naquele momento, ninguém imaginava que o advento dessa infecção viria a afetar o mundo tão profundamente. Conforme o vírus se disseminou e se tornou um problema mundial de saúde pública, cada país precisou adaptar seus recursos às diversidades e complexidades internas para lidar com a emergência da epidemia de HIV. No início, o desconhecimento das causas e origens do vírus 
criou receio nos governos, que temiam vincular-se ao tema. Por se tratar de uma infecção que afetava especialmente pessoas de grupos à margem da sociedade, as autoridades demoraram a reconhecer a epidemia como problema e responder à crise (UNAIDS, 2008).

A AIDS, ao combinar "comportamento sexual e doença” (GALVÃO, 2000), trouxe à tona uma série de questionamentos e embates entre diferentes concepções de saúde pública. Nesse contexto, a luta por dignidade de pessoas vivendo com HIV foi decisiva para legitimar uma resposta pública a ela.

Durante esse momento histórico, o Brasil passava pelo processo de redemocratização e começou a revisar seu sistema de saúde, que posteriormente foi transformado no atual Sistema Único de Saúde, o SUS. Após um período de repressão ditatorial, os movimentos sociais voltaram à tona clamando por mudanças na esfera política, em especial os grupos de gays, mulheres e pessoas negras (MACRAE, 1990), que dividiam espaço com grupos sindicais "tradicionais". A agenda da luta contra a AIDS, que de início se apresentou como pauta de grupos LGBTs, acabou incorporando diversos movimentos de pessoas à margem da sociedade.

Havia grande heterogeneidade nos movimentos que integravam essa agenda. A fala de um dos entrevistados ilustra essa questão ao notar que os atores que participaram da luta pela política de AIDS eram muito diferentes dos movimentos que protagonizaram a transição para a democracia.

Esse movimento inicial é um movimento que se inicia também no refluxo dos chamados movimentos sociais tradicionais - movimentos sindicais, movimentos corporativos - então esse movimento ele nasce [...] da construção da solidariedade, da ideia de responder a determinadas necessidades que estavam colocadas pelas populações que estavam sendo mais atingidas - movimentos de homossexuais, movimentos de usuários de drogas, movimentos de prostitutas - então esse [...] conjunto de atores era muito diferente dos atores que estavam na esteira [...] do processo de democratização, mas ao mesmo tempo fortalecia [...] o processo [...] porque colocava novas agendas. (Entrevista 1, 6 jan. 2011, Brasília). 
No Brasil, as primeiras matérias editadas sobre a doença nos jornais datam de 1981. Galvão (2000) destaca que a doença chegou antes na mídia do que nos registros oficiais, e isso é um fato importante para se compreender os primeiros anos da resposta. Antes mesmo de se consolidar uma política pública ou de haver informações claras sobre o vírus, a mídia desempenhou o papel de disseminadora de informações sobre o "câncer" ou "praga” gay que mais tarde se mostraram completamente infundadas. Para a autora, a mídia foi a principal responsável por moldar as primeiras respostas ao que ela chama de "mal de folhetim”. Em 1983, os primeiros grupos gays começam a se organizar ao redor da epidemia, pautados especialmente pelos noticiários. Destacam-se os grupos Somos e Outra Coisa. ${ }^{7}$

Esses grupos de militantes gays foram precursores ao cobrar do governo uma resposta adequada ao problema no estado de São Paulo (TEIXEIRA, 1997). Essa cobrança resultou em um grupo de trabalho que posteriormente deu origem ao primeiro programa de controle da AIDS no país (GALVÃO, 2000, p. 57). Em seguida, programas foram criados em mais dez estados brasileiros. Somente em 1985, o governo federal deu sua primeira resposta. Naquele ano, foi assinada a Portaria Federal do Ministério da Saúde $\mathrm{n}^{\circ} 236$ que determinava as diretrizes do "programa de controle da SIDA ou AIDS”. Em 1986, durante o governo Sarney, foi instituído o Programa Nacional de DST e AIDS no Ministério da Saúde, que só foi oficialmente consolidado em 1988. Desde o início, a política de AIDS ficou vinculada a outras DSTs/ISTs. ${ }^{8}$

A Constituição de 1988, além de estabelecer a participação social na saúde pública, também determinou a descentralização da gestão e das políticas de saúde no Brasil, atribuindo responsabilidades compartilhadas entre

7 As primeiras organizações lideradas por pessoas vivendo com HIV surgiram em 1985, o Grupo de Apoio à Vida (Gapa) o Grupo pela Valorização, Integração e Dignidade do Doente de AIDS (Grupo Pela Vida) e a Associação Brasileira Interdisciplinar de AIDS (Abia). Esta última era liderada por Herbert José de Sousa, o Betinho.

8 A sigla atualmente utilizada é Infecções Sexualmente Transmissíveis (ISTs), para destacar "[...] a possibilidade de uma pessoa ter e transmitir uma infecção, mesmo sem sinais e sintomas.” (DIAHV. Disponível em: http://www.aids.gov.br/pt-br/publico-geral/o-quesao-ist. Acesso em: 31 ago. 2018). 
os diferentes níveis de governo. A descentralização impacta diretamente a gestão da política de AIDS, haja vista que o programa nacional não pode intervir diretamente no nível local, deixando aos estados e municípios essa função. Isso torna a política de AIDS responsável por coordenar as diretrizes nacionais e formular e fomentar as políticas públicas sem, contudo, aplicá-las diretamente. Desde o início, a política nacional passou por diferentes designações e é um trabalho complexo identificar cada período e sua respectiva denominação. ${ }^{9}$ Contudo, a instituição contou com relativa estabilidade organizacional e de coordenação. Destaca-se o papel de Lair Guerra como primeira chefe de gestão, sendo pioneira na implementação da política (GALVÃO, 2000, p. 122-123).

O Banco Mundial destinou uma série de empréstimos a países de baixa e média renda a partir do final dos anos 1980 até o início dos anos 2000 para o combate à epidemia de AIDS. A temática era uma das agendas do banco, que tinha o enfoque especialmente em promover ações de prevenção nos países. Como em todo empréstimo promovido por essa organização internacional, os países deveriam entrar com uma contrapartida nacional somada ao montante do banco, e pagar o financiamento ao longo de até 15 anos. Esse foi um ponto de extrema importância para a resposta brasileira à AIDS, pois garantiu autonomia financeira para o funcionamento da política pública.

Lair Guerra foi a responsável por firmar o primeiro empréstimo do Banco Mundial no Brasil - o "Projeto de Controle de AIDS e DST" ou AIDS I, oficialmente sancionado em 1994 - que deu ao órgão recursos financeiros para ações de combate à epidemia. O projeto permitiu que a política tomasse o formato que tem hoje, com o incentivo e aproximação às organizações da sociedade civil e a criação de um "Setor de Articulação com ONG” (GALVÃO, 2000, p. 128). O primeiro projeto tinha o orçamento de 250 milhões de dólares - valores da época - com 160 milhões do Banco Mundial e 90 milhões de contrapartida do Tesouro Nacional.

Em 1996, durante o governo Fernando Henrique Cardoso, é aprovada a lei ${ }^{\circ}$ 9.313, de 13 de novembro de 1996, que autoriza a distribuição gratuita e universal de medicamentos antirretrovirais aos portadores do vírus HIV.

9 Consultar Galvão (2000, p. 18-19) para uma lista de nomes entre 1987 e 1996. 
Desde 1995, o Brasil fabricava o AZT (azidotimidina) ${ }^{10}$ nacionalmente, e outros medicamentos foram incorporados à produção nacional em seguida. Essa iniciativa acabou desagradando farmacêuticas internacionais, e o Brasil foi denunciado na Organização Mundial do Comércio (OMC) pelos Estados Unidos por violar as regras internacionais de patentes em 2001. Após o governo brasileiro ameaçar fazer o licenciamento compulsório da medicação, a queixa foi retirada (MINISTÉRIO DA SAÚDE, 2015).

Em 2005, o governo brasileiro recusou a ajuda financeira do programa do governo norte-americano Pepfar (Plano de Emergência do Presidente para a assistência à AIDS - President's Emergency Plan for AIDS Relief) por conta dos condicionantes ao empréstimo. Entre as exigências, o programa pedia a condenação pública da prostituição e a exclusão desse grupo da política. Além disso, tinha como diretriz o incentivo à abstinência, a chamada política do ABC (abstinence, be faithful, condomise - abstinência, fidelidade e preservativo), que foi considerada pelo órgão retrógrada e insuficiente para a resposta brasileira (DIAHV, 2015).

Desde sua instauração, o programa de AIDS brasileiro tem sido considerado um exemplo bem sucedido de prestação de serviços de cuidado em HIV com o engajamento da sociedade civil (PARKER, 2003; BERKMAN et al., 2005). Como a descentralização do sistema de saúde criou a necessidade de associação entre a burocracia central e movimentos sociais locais, esses grupos serviram de ponte para implementar as políticas de HIV na ponta (RICH, 2013). Além disso, o programa conta com espaços de incidência política da sociedade civil, sendo os principais a Comissão Nacional de DST, AIDS e Hepatites Virais (Cnaids) e a Comissão de Articulação com os Movimentos Sociais (Cams). O Brasil também esteve na vanguarda global ao fornecer tratamento universal gratuito e por ter garantido a produção de medicamentos antirretrovirais nacionalmente (PARKER, 2003).

10 “AZT ou ZDV, um dos primeiros nucleosídeos da transcriptase reversa (NRT) aprovados pela Food and Drug Administration (FDA) - a agência de vigilância sanitária dos Estados Unidos da América - em 1987, é um medicamento utilizado para retardar o desenvolvimento da AIDS” (UNAIDS, 2017). 
Uma característica do perfil gestor da política de AIDS no Brasil é a entrada de militantes de movimentos sociais nos quadros técnicos. A partir da década de 1990, vários membros de organizações da sociedade civil com atividades em HIV/AIDS passaram a integrar a equipe do programa nacional (GALVÃO, 2000, p. 101). Desde então, é comum que ativistas sejam convidados a compor quadros burocráticos.

É importante notar que a consolidação da política nesse primeiro momento deu base para as grandes transformações ao longo dos anos e permitiu que diversos atores se mobilizassem ao redor da pauta. O envolvimento e a incorporação de movimentos sociais na agenda do governo também são práticas que têm sido adotadas desde o início da política e um traço importante da identidade e da atuação da instituição.

\subsection{O Ministério da AIDS - consolidação da autonomia organizacional}

Conforme observamos ao longo do histórico, a identidade construída por várias lutas políticas e momentos de afirmação ajudou a criar uma forma de atuação da resposta à AIDS no Brasil, baseada na combinação entre especialização técnica e forte interação com movimentos sociais. A visibilidade da política, por conta do vírus e da reputação internacional da reação brasileira, acabou por criar ao redor da instituição uma aura de excepcionalidade dentro do Ministério da Saúde.

O arranjo administrativo e financeiro da política também reforçou seu caráter singular. Os recursos provenientes do Banco Mundial a partir de 1994 possibilitaram autonomia em relação aos recursos do governo federal. Nesse contexto, um dos ministros da saúde (entre 1996-1998) apelidou a instituição de "Ministério da AIDS", conforme relata a seguinte entrevista:

Esse ministro [Carlos] Albuquerque, [...] ele chamava o Programa de AIDS de Ministério da AIDS. Sempre quando marcava audiência com ele que ia na sua sala, ele vinha, abria a porta, e falava "Boa tarde, Ministro da AIDS". Era uma forma jocosa obviamente, era uma crítica, mas era uma forma meio de revanche. (Entrevista 20, 27 set. 2017). 
Nos primeiros anos da política, isso era especialmente enfatizado, tanto por conta da quantidade de recursos quanto pela capacidade e especialização técnica dos funcionários. Assim como o ministro da saúde anteriormente citado, uma das pessoas entrevistadas compara a organização da política a um ministério paralelo.

[Era] como se fosse um ministério paralelo, era assim que era entendida a resposta, porque você tinha toda uma estrutura repetida numa escala menor, você tinha comunicação numa escala menor, você tinha a área internacional numa escala menor. Você tinha de fato um ministério paralelo que também por conta dos PRODOCS ${ }^{11}$ funcionava de um jeito muito independente, muito com a participação do Banco Mundial. (Entrevista 5, 2 jun. 2012, Brasília).

Para melhor compreender o porquê dessa disposição peculiar da política, e como isso foi se transformando ao longo do tempo, é preciso observar a forma como os recursos do Banco Mundial para AIDS operavam no Brasil. Com o primeiro empréstimo do banco, foram definidas condições para a aplicação dos fundos. Entre elas, o estabelecimento de uma equipe técnica especializada para a implementação, o monitoramento e a avaliação das ações do programa.

No Brasil, desde o início do projeto, o recebimento dos repasses, a contratação de consultores e a especialização organizacional foram processos levados a cabo por meio da estrutura estatal para evitar que a política fosse descontinuada, a exemplo do que havia acontecido na Argentina (ROCHA, 2001). No caso portenho, os recursos foram implementados paralelamente ao Estado por uma equipe gestora própria do Banco Mundial, fora da alçada do Ministério da Saúde, conforme observado por um dos entrevistados:

O Banco Mundial quando chegou, queria criar, como fez na Argentina - e eu estive trabalhando na Argentina e vi realmente o desastre que foi o projeto Lusida - o Banco queria criar um projeto à parte da estrutura do Ministério [da Saúde] [...]. A Lair [Guerra] foi bastante incisiva nisso, ela

${ }^{11}$ Programa de Apoio a Projetos Institucionais com a Participação de Recém-Doutores. 
discordou completamente, e o programa passou a ser também o gestor do recurso do Banco Mundial. Na Argentina, o que aconteceu: criaram o projeto Lusida, e tinha o programa de AIDS, que corria em paralelo. Quando acabou o Lusida, o programa de AIDS praticamente não existia e continua a não existir praticamente, porque não havia recursos... e o Lusida acabou e todo mundo se dispersou. O programa de AIDS [no Brasil] não, o projeto do Banco acabou e o Ministério assumiu toda aquela estrutura que era antes financiada pelo Banco Mundial. (Entrevista 20, 27 set. 2017).

Essa identidade marcou de maneira profunda a atuação dos gestores e influenciou de forma direta a sua reação a mudanças. Como a política espelhava a estrutura de um programa de organização internacional, havia uma proposta de autossuficiência que foi absorvida pelo Ministério da Saúde.

A partir desse processo, a política ficou organizada em especialidades técnicas, e definiu-se uma rede hierárquica entre os gestores. Por ser um programa, havia certa flexibilidade para que isso acontecesse. Conforme explica uma das pessoas entrevistadas, essa especialização progressiva resultou em diferentes chefes de área, que se organizavam de acordo com as necessidades da epidemia. A partir do empréstimo AIDS 3, essa "superestrutura" foi consolidada oficialmente pela entidade, e os chefes tiveram seu poder legitimado.

O que acontece, quando você tem um empréstimo do Banco Mundial, lá na década de 1990, quando chega o primeiro empréstimo, o programa começa a se organizar estruturalmente. Essa estrutura segue uma lógica do que se dizia que era a lógica das epidemias, das endemias. A lógica das epidemias é você ter uma unidade de vigilância, uma unidade de assistência. Na verdade, do ponto de vista da vigilância é uma unidade de vigilância e o pessoal do planejamento, então você vai aí juntando... Qual foi o diferencial do Brasil nessa época: ele criou uma unidade de sociedade civil. Quando a gente começa a ter testes para fazer exame de HIV, pra fazer fluxograma de quantas vezes tira sangue -0 [teste] western blot - você começa a ter gente que lide com laboratório, [...] com o passar do tempo, essas áreas especializadas elas vão ganhando força. E aí chega um momento que num 
dos empréstimos, que se não me engano foi o AIDS 3, ele determina claramente essa superestrutura, esse organograma, que cada uma dessas unidades tem um chefe, só que ele era naquele momento chefe de verdade do programa. ${ }^{12}$

Outra característica importante dessa organização é que o coordenador do programa poderia ter interlocução direta com os estados e municípios, encaminhando os recursos do Banco Mundial e desenvolvendo as ações sem precisar passar pelo Secretário de Vigilância em Saúde, conforme mencionado pela entrevista a seguir:

Veja, quando você é programa você flutua, você pode ter 500 pessoas trabalhando pra você, 20 áreas, entendeu. O programa tinha várias áreas técnicas, mas o que acontece, essas áreas técnicas atuavam direto com estados e municípios sem que isso fosse a prática do SUS. Então já existia uma discussão que era o programa passar a atuar mais integrado ao SUS. Sempre foi SUS, mas atuar como se fosse, porque existe toda uma hierarquia do SUS, você tem que lidar com secretários [dentro do Ministério da Saúde, e nos estados e municípios]. Então alguns estados, o ponto focal de AIDS tinha mais poder do que o pessoal da atenção básica por exemplo, era muito poder, porque era muito dinheiro envolvido, os recursos iam [direto] para estados e municípios. ${ }^{13}$

Essa autossuficiência possibilitou que as ações do departamento fossem desenvolvidas em paralelo não só aos recursos financeiros do Ministério da Saúde, mas também sem a necessidade explícita de apoio técnico de outras unidades do órgão. Uma das consequências disso é que a especialização técnica dos quadros cria uma grande complexidade no processo decisório.

\footnotetext{
${ }^{12}$ Assim como em minha dissertação (CARTAXO, 2018), oculto o número da entrevista com vistas a preservar o anonimato da pessoa entrevistada

${ }^{13}$ Para manter o anonimato da entrevista, optou-se por omitir o seu número.
} 
Por outro lado, como explica uma das entrevistas, os saldos dessas decisões são positivos por serem resultado de um trabalho a muitas mãos.

O que eu digo é que essa estrutura que a gente tem é engomosa, ela é difícil de andar. Tudo parece lento, mas quando sai, sai muito bem feito, entendeu. Tudo que é produzido aqui é muito precioso. Agora, demora pra produzir, por causa desse diálogo interno, que é engomoso, é demorado. ${ }^{14}$

Por mais que houvesse robustez no desempenho da política pública, a condição de programa ainda trazia certa fragilidade com relação à continuidade da resposta à AIDS dentro do Ministério da Saúde. Sendo um programa, não havia estabilidade institucional, e por mais que houvesse flexibilidade interna, a política ainda estava no patamar mais baixo da hierarquia do Ministério da Saúde. Nesse momento, a diretoria começou a discutir com a Secretaria de Vigilância em Saúde a possibilidade de ascensão hierárquica da política de AIDS e de DST.

\subsection{A transformação em departamento}

Durante a gestão da diretora Mariângela Simão (2006-2010), a política de AIDS passou por uma grande transformação interna. Em 2009, o Programa de DST/AIDS do Ministério da Saúde passou a integrar a estrutura da Secretaria de Vigilância em Saúde (SVS) como departamento, não mais como programa. O Decreto $n^{\circ} 6.860$, de 2009, também definiu a incorporação do programa de Hepatites Virais a suas atribuições, centralizando a aquisição dos medicamentos desse agravo naquele órgão. Dessa forma, o programa tornou-se Departamento de Vigilância, Prevenção e Controle das IST, do HIV/AIDS e Hepatites Virais.

Ao longo de mais de 30 anos da política de AIDS, o Diahv passou por diversas mudanças organizacionais. A transformação em departamento aumentou o patamar da política de AIDS dentro do Estado. Ao integrar a Secretaria de Vigilância em Saúde, essa instituição se tornava não apenas

${ }^{14}$ Para manter o anonimato da entrevista, optou-se por omitir o seu número. 
uma política de governo, mas também uma política de Estado, garantindo a continuidade da resposta à epidemia de HIV em longo e médio prazo, a despeito de mudanças na condução do executivo nacional. As implicações dessa transformação são o terreno de interpretações divergentes dos gestores envolvidos.

Segundo entrevistas, o debate vinha sendo travado internamente ao longo de vários anos no Ministério da Saúde, mas apenas em 2009, durante a gestão de Mariângela Simão, a mudança se consolidou de fato, conforme explicado a seguir:

Primeiro que tem um entendimento errado, e provavelmente ainda tem, por parte de somente alguns setores da sociedade civil, de que teria sido uma perda virar departamento. [Isso] é uma bobagem, porque na verdade foi a institucionalização de um status dentro do Ministério, porque por exemplo à época [...] você tinha o Ministro da Saúde, [o] Secretário Executivo e os secretários das áreas específicas, e abaixo dos secretários, você tem os departamentos, e abaixo do departamento você tem os programas, certo? Então na verdade o interesse e a movimentação para que o programa que estava lá embaixo na cadeia alimentar do Ministério, mas estava bem do ponto de vista político, de que o programa fosse institucionalizado como departamento, começou na época do Alexandre Granjeiro [ex-coordenador], que quando estava [na direção] iniciou o processo, com a reforma administrativa do Ministério. (Entrevista 18, 12 set. 2017).

A partir desse acontecimento, o HIV passou a ter um status elevado em relação a outros agravos, e o Secretário de Vigilância em Saúde passou a ser o encarregado direto da pasta. Anteriormente, enquanto programa, a política estava subordinada ao Departamento de Vigilância Epidemiológica.

Ao mudar de patamar, o órgão também absorveu a responsabilidade das Hepatites Virais, assumindo novas funções. Após anos de funcionamento com um número considerável de funcionários divididos por áreas temáticas, mais um componente foi adicionado à logística da organização. Para que toda a estrutura fosse consolidada no quadro ministerial, no qual o 
organograma e o número de cargos de confiança são definidos por medida provisória, algumas adaptações foram feitas, como a fusão de coordenações existentes em áreas temáticas. Isso acabou dissolvendo e reagrupando a organização estabelecida em formato de programa, que englobava várias áreas temáticas. As redes pré-estabelecidas foram abaladas e os antigos chefes perderam a posição que outrora ocupavam.

A partir da transformação em Departamento, as responsabilidades foram limitadas a duas coordenações: i) Coordenação-Geral de Ações Estratégicas em IST, AIDS e Hepatites Virais; e ii) Coordenação-Geral de Vigilância e Prevenção de IST, AIDS e Hepatites Virais, com seis cargos de confiança. Isso não foi uma mudança fácil para os gestores, conforme esclarece o seguinte trecho:

Então essa política foi responsável por toda uma organização programática, por todo um grupo de pessoas, uma tomada de decisão muito forte, tinha muito dinheiro envolvido, os empréstimos do banco mundial, então isso aí fez toda uma diferença pra essa fortaleza. Aí você imagina colocar tudo isso aí dentro de um departamento. A princípio caberia, o que tinha que ser feito? Atuar dentro das regras do SUS, mas essa atuação foi um processo traumático, porque as pessoas que trabalhavam aqui na época tinham uma sensação de muita liberdade, muita autonomia. ${ }^{15}$

A entrevista a seguir explica como aconteceu essa mudança, quando o grande número de áreas temáticas ficou reorganizado dentro de três coordenações.

As áreas continuam existindo, mas precisaram ser submetidas a uma nova hierarquia interna. Com a criação do departamento não foram as ações que foram restringidas mas sim a estrutura organizacional. Anteriormente, tínhamos unidades e assessorias estruturadas em função das suas atribuições funcionais e com o Decreto n ${ }^{\circ}$ 6860/2009 que cria o departamento

${ }^{15}$ Para manter o anonimato da entrevista, optou-se por omitir o seu número. 
estabelece uma estrutura formada por duas coordenações técnicas e uma coordenação administrativa. Mas continuamos funcionando em conformidade às nossas necessidades e atribuições de forma oficiosa para não quebrar a sintonia e organicidade interna. (Entrevista 8, 26 mai. 2017).

Segundo uma das entrevistas, essa mudança causou certo desconforto entre os funcionários, pois eles se viram submetidos a uma nova ordem mais centralizada, com menor autonomia para os chefes temáticos. A rede informal previamente consolidada foi quebrada, conforme explica uma das entrevistas.

Esses chefes [de áreas temáticas] não podem assinar nada. Só quem assina é quem tem cargo. Então não importa quantas pessoas estejam atrás da diretora, só ela e seus dois substitutos que assinam - essas três pessoas. Então você imagine que antes saía memorando de um canto para outro, a unidade técnica, a assessoria pra lá. Essa circulação de documentos não existe mais, isso foi uma questão burocrática que foi realmente uma regulamentação. (Entrevista 13, 16 jun. 2017, Brasília).

Quando o programa era vinculado de forma distante à hierarquia do Ministério da Saúde, ele tinha a liberdade de definir sua própria organização. Os chefes das áreas temáticas, mesmo sem cargo, tinham responsabilidades e autonomia. Com a transformação do programa de AIDS em departamento, essa flexibilidade foi desfeita e as redes dissolvidas. Os chefes de área, que possuíam autonomia administrativa e responsabilidades dentro da hierarquia, perderam o status, mesmo que ainda mantivessem as mesmas atribuições.

Na medida em que o programa foi entrando na estrutura do Ministério [...] a questão da autonomia, a ideia de que você pode responder diretamente pelas coisas, que eu acho positiva na agenda pública [...] você se perde um pouco nesse organograma, então quem responde é sempre uma hierarquia [...] e a AIDS tinha muito esse protagonismo. [...] Na hora que vira departamento essa figura [do chefe de área temática] não existe mais, ela está ali mas ela não 
assina um documento, não passa documento para outra área. Desburocratizou isso, e para muitos deles isso foi muito difícil, então muitos desses chefes foram embora [...] Eu vi vários saírem, vários chefes, unidade de DST se acabou, unidade de laboratório permaneceu, a unidade de sociedade civil juntou com prevenção, porque eram separadas. E aí hoje houve um reagrupamento. (Entrevista 13, 16 jun. 2017).

As áreas temáticas dentro do arranjo de programa passaram por uma reconfiguração, tentando ao máximo manter em operação todas as áreas que vinham trabalhando dentro do órgão. Para acomodar essa organização, foi definido um arranjo informal que orientava o trabalho cotidiano dos gestores.

Segundo uma das entrevistas, essa estrutura organizacional peculiar e a mudança na flexibilidade anterior trouxeram dificuldades de adaptação para os funcionários, visto que compõem uma realidade diferente de outras doenças trabalhadas no Ministério da Saúde. Após a dissolução das redes de trabalho anteriores, houve uma grande dificuldade em operar dentro da organização do Ministério da Saúde.

Aqui é uma superestrutura, que eu não diria paralela ao ministério porque está integrada, está dentro do departamento, mas são pessoas assim no final das contas que vivem no seu próprio mundo, porque não entendem a lógica do ministério. Muitos deles, que entraram depois, não entendem a lógica do ministério porque não vivem, vivem aqui dentro nessa estrutura. ${ }^{16}$

Alguns gestores argumentam que, com a transformação política, perdeu-se a interlocução com o alto escalão do Ministério. Questionam a mudança nos relacionamentos e na liberdade autoral que se concedia às ações da política. Vemos certo paradoxo pois, por mais que houvesse maior importância hierárquica, isso não foi claramente traduzido em aproximação com o alto nível do poder. Para um dos relatos, enquanto programa a

${ }^{16}$ Para manter o anonimato da entrevista, optou-se por omitir o número. 
política tinha um trato melhor com o ministro, por ter acesso direto a ele e liberdade em fazer publicações:

O programa de AIDS tinha autonomia, tinha acesso direto ao ministro, sabe? Nós tínhamos a nossa editoração de documentos, não dependia do Ministério, publicava, tinha realmente autonomia de decisão técnica e política também, na medida em que tinha acesso direto ao ministro, e isso foi bastante claro nos anos 1980, 1990. (Entrevista 20, 26 set. 2017, Brasília).

A integração no Ministério da Saúde acabou sendo interpretada por alguns como burocratização e engessamento das funções do Diahv. Mesmo assim, um dos relatos ressalta que isso se confunde com a conjuntura política mais ampla.

O que eu percebi foi que a gente ficou um pouco mais engessado, mas eu não sei se foi pela mudança de programa para departamento ou pela própria conjuntura do Ministério que mudou mesmo. Eu percebo que a gente tinha um pouco mais de liberdade. ${ }^{17}$

Contudo, a força da autonomia da política não é unanimidade entre os entrevistados. Para um dos gestores, o isolamento do departamento separava as ações realizadas pelo Diahv do resto dos programas do Ministério da Saúde, e isso precisava ser modificado para conseguir avançar a luta contra a epidemia.

No campo da política, [a] principal tarefa era tirar o departamento do isolamento que ele tinha dentro do Ministério da Saúde, é como ele se não fosse parte [do Ministério da Saúde]. [...] O fundamental era garantir primeiro que a política pública permanecesse, ela não fosse isolada como política pública, que ela atualizasse, que tivesse uma versão 2.0, e que ela não perdesse nenhum dos ganhos históricos que ela teve e que ao contrário, que a gente conseguisse aprofundar num curto espaço de tempo para recuperar o tempo perdido e para colocar a epidemia sob controle. (Entrevista 19, 15 set. 2017, Brasília).

${ }^{17}$ Para manter o anonimato da entrevista, optou-se por omitir o número. 
Outra entrevista reforça, ainda, essa perspectiva. Para o respondente em questão, o grande problema é que esse organograma abrangente e especializado acabou por tornar o trabalho do departamento tão independente a ponto de separá-lo da lógica do Ministério. Isso é considerado prejudicial porque, ao mesmo tempo em que há autonomia, continua a existir a necessidade de operar dentro da lógica organizacional federal. Os gestores acabam vivendo "em seu próprio mundo".

Isso [...] é quase uma secretaria na estrutura de um departamento. Só comparar com a tuberculose, com a malária, todos eles estão dentro de um departamento. Existe o Devit, e lá dentro tem a coordenação de tuberculose, coordenação de malária, e essas pessoas fazem a mesma atividade programática com bem menos gente, lidando com atenção básica, coisa que aqui não é assim. Aqui é uma superestrutura, que eu não diria paralela ao ministério porque está integrada, está dentro do departamento, mas são pessoas que, no final das contas, vivem no seu próprio mundo, porque não entendem a lógica do Ministério, muitos deles, não entendem a lógica do Ministério porque não vivem. ${ }^{18}$

A perda de autonomia não é consenso entre os entrevistados. Para alguns, a transformação moveu o departamento no sentido contrário.

Quando você é um programa, [...] mais subordinação você tem acima de você, para você ver: tem programa, aí você tem departamento, aí você tem secretaria, e aí você tem ministro. E o fato de estarmos como departamento agora, isso já te dá uma autonomia maior, e uma facilidade de você chegar aos gestores maiores da instituição, porque de departamento você só tem o secretário e de secretaria você tem o ministro, quer dizer, essa mudança de estrutura viabiliza melhor os nossos trâmites administrativos, políticos e técnicos, então a facilidade de interlocução para a gente como departamento é bem melhor. (Entrevista 15, 31 jul. 2017, Brasília).

${ }^{18}$ Para manter o anonimato da entrevista, optou-se por omitir o número. 
Antes da mudança para departamento, a organização administrativa e gerencial dava maior visibilidade para as áreas temáticas e para as redes de pessoas que eram estruturadas ao redor delas. No momento em que essa organização foi rompida, os gestores passaram a enxergar essa nova ordem como um rompimento da antiga forma de fazer a política e, consequentemente, da identidade autônoma da política pública. Segundo as entrevistas, antes redes autogestionadas ditavam as decisões técnicas e as relações da instituição com estados e municípios. Após a transformação, alguns gestores interpretaram que o “engessamento” burocrático dissolveu as possibilidades de ação.

A transformação organizacional do Programa Nacional de AIDS em departamento da SVS foi o marco de um processo mais amplo de transformação que envolve interpretações sobre: i) a institucionalização da política; e ii) a autonomia da organização. Opiniões sobre esses dois movimentos podem ser identificadas nas falas dos atores entrevistados, discursos muitas vezes divergentes. Além disso, concepções sobre a autonomia organizacional e individual amiúde se sobrepõem, trazendo à tona a discussão sobre autonomia como capacidade, ressaltada por Abers e Santiago (2017).

Seguindo a lógica de DiMaggio (1988), compreendemos a institucionalização como um processo que reflete o poder relativo de interesses dos atores e sua capacidade de mobilização. Destarte, esse processo gera interpretações sobre as mudanças do Diahv, entre visões dos limites impostos pela conjuntura política e visões da institucionalização e autonomia do departamento. Dentro de cada um desses debates, temos o olhar para uma parte específica da política ou para um acontecimento particular. A forma como os gestores enxergam a identidade da política foi alterada nesse momento de transformação.

As falas apresentadas mostram como a mobilização ao redor da autonomia da política é um ponto importante para os gestores. A construção histórica da política pública, por meio da força das características organizacionais do Diahv, acabou por consolidar um mito nativo sobre a instituição, que não necessariamente é compartilhado por todos. Esse mito estabeleceu um olhar particular sobre as atribuições do departamento e o modo como a política pública deveria se comportar dentro do quadro do Ministério da Saúde. Assim como Hallett e Ventresca (2006) observam em Gouldner, o momento anterior à transformação em departamento pode ser definido como um “mito de Rebecca”, onde 
há idealização do quadro organizacional anterior e uma memória do padrão indulgente que continua sendo mobilizada pelos funcionários. ${ }^{19}$

Oito anos após a transformação, gestores relatam que ainda estão se adaptando e que, até o momento, não foi absorvida por todos. A manutenção da estrutura organizacional em várias áreas técnicas, apesar de não ter mantido a autonomia dos gestores que chefiavam esses grupos, procurou manter a identidade característica da política de AIDS e, de certa forma, garantir a continuação do que estava sendo feito.

Por outro lado, a controvérsia em torno da autonomia do Diahv acaba por influenciar a forma como os gestores enxergam as próprias capacidades. Em locais de trabalho contruídos tendo em vista uma política autônoma, a visão sobre as possibilidades de atuação dos gestores é ampliada. Cabe notar que as transformações a nível de alto escalão também afetam a percepção dos atores sobre a autonomia individual e organizacional, nos termos do debate proposto por Abers e Santiago (2017).

Voltando a DiMaggio (1988), afirmamos que o processo de institucionalização - que por vezes ocorre de forma problemática - é baseado especialmente no trabalho prático dos atores. Esse trabalho é ancorado nos significados construídos pelas pessoas sobre sua ação social. Nesse momento, a construção da identidade da política pública afetou a forma como os indivíduos entrevistados interpretaram a mudança. As críticas dos gestores às transformações indicam que os burocratas notaram uma alteração nos recursos necessários ao burocrata para que tome suas decisões, e isso afetou diretamente a forma como enxergam o próprio trabalho.

A partir da análise das entrevistas, observa-se que a mudança organizacional e contextual da posição da política de AIDS dentro do Ministério da Saúde é um assunto de preocupação para os entrevistados, e que esse tema está em disputa entre os diferentes gestores envolvidos. As capacidades e

${ }^{19}$ Para construir o conceito de "mito de Rebecca”, Gouldner (1954) busca inspiração no livro Rebecca (1938) de Daphne du Maurier, no qual descobre-se ao final que a mulher idealizada, Rebecca, era na verdade cruel e descompensada. Nesse capítulo, trazemos o mito de Rebecca como uma alegoria para uma ordem organizacional anterior e como uma categoria nativa para explicar a mudança de paradigma institucional, sem, necessariamente, chegar a um juízo de valor negativo ao final da análise. 
a autonomia do órgão dependem de uma série de variáveis institucionais e políticas em constante construção.

A história da política instituiu uma ordem social baseada na legitimidade das áreas temáticas e na autonomia de aplicação da política. Conforme Emirbayer e Goodwin (1994), a autonomia individual não é concebida sozinha, mas é resultado da interface entre identidade e relações em rede. A consolidação histórica da política gerou um modus operandi que ganhou legitimidade externa e aceitação interna, de modo que qualquer mudança seria vista como uma influência ao modo de operar.

As redes ativistas consolidadas no início da epidemia foram a base da sociabilidade e das formas de trabalho dos gestores. A transformação organizacional acabou abalando práticas consolidadas de atuação institucional e causando certo estranhamento por parte dos gestores. Por outro lado, essa mudança se confunde com outros acontecimentos no contexto do Ministério da Saúde, onde crises políticas resultaram na saída de dois diretores da chefia do departamento (CARTAXO, 2018). Dessa forma, por mais que a mudança organizacional seja um gatilho para uma crítica à mudança, a visão otimista da ordem anterior também pode ser relacionada a um momento político mais favorável dentro do Ministério da Saúde.

Por mais que não seja a única explicação para as diferentes interpretações sobre a mudança da política, essa transformação organizacional é um marco importante para sua consolidação e afetou diretamente a dinâmica de atuação dos indivíduos. Observar as diferentes interpretações sobre esse momento ajuda a ter uma visão próxima de como a sociabilidade e o histórico da política afetam a organização social e geram controvérsias sobre o local de trabalho dos gestores.

\section{Considerações finais}

A política de AIDS continua a ser uma das respostas nacionais com maior visibilidade e com o maior número de recursos do governo federal. A sua subsistência exige a mobilização contínua dos gestores e uma grande equipe é responsável por mantê-la viva e relevante dentro do Ministério da Saúde. Conforme visto no histórico, o ativismo, por meio de uma 
coordenação de articulação social, é uma característica importante da sociabilidade dos gestores e da própria organização das ações.

Observamos que os significados construídos pelos gestores sobre a transformação da política dizem respeito a uma forma de atuação característica que foi consolidada ao longo de vários anos de política pública. Na medida em que foi instaurada uma controvérsia sobre essa mudança, defendemos que um "mito de Rebecca” (HALLETT; VENTRESCA, 2006) tomou lugar nas interpretações sobre o momento anterior à consolidação do departamento.

Esse mito afetou as percepções sobre a legitimidade e autonomia dos indivíduos, pois as redes de trabalho anteriores foram dissolvidas dando lugar a uma nova ordem institucional. A legitimidade informal, criada por laços de confiança previamente estruturados entre as áreas temáticas, foi abalada. A decisão tomada por órgãos superiores do Ministério da Saúde e articulada pelos diretores afetou os gestores de nível técnico ao criar uma nova dinâmica de interação entre eles.

As visões subjetivas analisadas ajudam a compreender como as práticas institucionais significam e moldam as narrativas, pois a partir delas podemos compreender a linha de raciocínio por trás das organizações políticas. Por meio da análise dos efeitos dessa nova forma de gestão, é possível ler as interações e os processos que criam e abalam a ordem social. Os gestores não são passivos ao receber as mudanças e eles as interpretam de acordo com sua realidade (HALLETT; VENTRESCA, 2006).

A partir do exemplo do Departamento de IST, AIDS e Hepatites Virais do Ministério da Saúde, reforçamos que as instituições são ambientes habitados por indivíduos e precisam ser analisadas por meio de suas interações e significados sociais. Essa abordagem é importante para que se possa expandir a compreensão sobre a atuação de órgãos do Estado na implementação de políticas públicas.

Por outro lado, no contexto de uma política pública construída por meio do ativismo, a análise de como os indivíduos enxergam o local de trabalho é bastante influenciada por conceitos e prioridades ativistas. Ao longo das entrevistas, pudemos notar que a mudança organizacional não causou apenas o rompimento da ordem anterior, mas também abalou os conceitos pré-construídos de como a política pública deveria atuar e de como seria mais efetivo o envolvimento do gestor. 
A agenda de pesquisa do ativismo institucional envolve uma ampliação do debate sobre o papel do ator nas instituições. Mostramos que as interpretações dos gestores sobre as mudanças têm um papel explicativo importante sobre a dinâmica institucional, e que burocratas têm suas dinâmicas afetadas por decisões top down. Para avançar ainda mais na compreensão do papel do ativismo na ação burocrata, estudos de interpretações subjetivas sobre mudanças são bastante úteis porque capazes de relacionar, de maneira equânime, aspectos organizacionais e o trabalho interativo dos gestores.

\section{Referências}

ABERS, Rebecca Neaera; SANTIAGO, Ariadne. A autonomia do burocrata técnico: o caso do licenciamento ambiental do Ibama. In: DE PAULA, Jean Marla P. et al. (org.). Burocracia federal de infraestrutura econômica: reflexões sobre capacidades estatais. Brasília: Ipea, 2017.

ABERS, Rebecca Neaera; SERAFIM, Lizandra; TATAGIBA, Luciana. Repertórios de interação estado-sociedade em um estado heterogêneo: A experiência na era Lula. Dados - Revista de Ciências Sociais, Rio de Janeiro, v. 57, n. 2, p. 325-357, 2014.

BERKMAN, Alan et al. A critical analysis of the Brazilian response to HIV/AIDS: lessons learned for controlling and mitigating the epidemic in developing countries. American Journal of Public Health, v. 95, n. 7, p. 1162-1172, 2005.

BRANDÃO, Igor Ribas. VILAÇA, Luiz Henrique. Ativismo burocrático na construção de Belo Monte e na inclusão socioprodutiva de catadores de materiais recicláveis. Anais. In: ENCONTRO INTERNACIONAL PARTICIPAÇÃO, DEMOCRACIA E POLÍTICAS PÚBLICAS, 3., 2017, Vitória/ES. Anais [...] Vitória/ES: Universidade Federal do Espírito Santo (UFES), 2017. 
BRANDÃO, Igor R.; VILACA, Luiz. Ativismo burocrático na construção de Belo Monte e na inclusão socioprodutiva de catadores de materiais recicláveis. In: ENCONTRO INTERNACIONAL PARTICIPAÇÃO, DEMOCRACIA E POLÍTICAS PÚBLICAS, 3., 2017, Vitória/ES. Anais [...] Vitória/ES: Universidade Federal do Espírito Santo (UFES), 2017.

BRASIL. Ministério da Saúde. Departamento de Vigilância, Prevenção e Controle das IST, do HIV/Aids e das Hepatites Virais. História Ilustrada da AIDS, 2014, 7 min., son., color. Disponível em: https://www.youtube. com/watch?v=ShaCZ9b1MKs. Acesso em: 27 ago. 2018.

CARTAXO, Mariana. A política de AIDS: conflitos e transformações. 2018. 100 f., il. Dissertação (Mestrado em Ciência Política) - Instituto de Ciência Política, Universidade de Brasília, Brasília, 2018.

DIMAGGIO, Paul. Interest and agency in institutional theory. In: ZUCKER, Lynne G. (org.). Institutional patterns and organizations: culture and environment. Pensacola, Florida: Bellinger Publishing, 1988.

EMIRBAYER, Mustafa; GOODWIN, Jeff. Network analysis, culture, and the problem of agency. The American Journal of Sociology, v. 99, n. 6, p. 1411-1454, 1994.

EMIRBAYER, Mustafa; MISCHE, Ann. What is agency? American Journal of Sociology, v. 103, n. 4, p. 962-1023, 1998.

GALVÃO, Jane. AIDS no Brasil: a agenda de construção de uma epidemia. Rio de Janeiro: Associação Brasileira Interdisciplinar de AIDS, 2000.

GOULDNER, Alvin W. Patterns of industrial bureaucracy. Glencoe: Free Press, 1954.

HALLETT, Tim; VENTRESCA, Marc J. Inhabited institutions: social interactions and organizational forms in Gouldner's "Patterns of Industrial Bureaucracy”. Theory and Society, v. 35, n. 2, p. 213-236, 2006. 
LAWRENCE, Thomas B.; SUDDABY, Roy; LECA, Bernard. Introduction: theorizing and studying institutional work. In: LAWRENCE, Thomas B.; SUDDABY, Roy; LECA, Bernard. (org.). Institutional work actors and agency in institutional studies of organization. Cambridge, New York: Cambridge University Press, 2009.

MACRAE, Edward. A construção da igualdade: identidade sexual e política no Brasil da “abertura”. Campinas: Editora da Unicamp, 1990.

MENICUCCI, Telma M. G. Os argumentos analíticos: a perspectiva histórica e institucional. In: MENICUCCI, Telma M. G. Público e privado na política de assistência à saúde no Brasil: atores, processos e trajetória. Rio de Janeiro: Editora Fiocruz, 2007.

MISCHE, Ann. De estudantes a cidadãos: redes de jovens e participação política. Revista Brasileira de Educação, n. 5-6, p. 134-150, 1997.

OLIVEIRA, Marília Silva de. Movimento para as instituições: movimento ambiental, partidos políticos e a liderança de Marina Silva. 2016. 303 f., il. Tese (Doutorado em Ciência Política) - Instituto de Ciência Política, Universidade de Brasília, Brasília, 2016. PARKER, Richard. Building the foundations for the response to HIV/AIDS in Brazil: the development of HIV/AIDS policy, 1982-1996. Divulgação em Saúde para Debate, v. 27, p. 143-183, 2003.

RICH, Jessica. Grassroots bureaucracy: intergovernmental relations and popular mobilization in Brazil's AIDS policy sector. Latin American Politics and Society, v. 55, n. 2, p. 1-25, 2013.

ROCHA, Laura. Polémica por el fin del proyecto Lusida. La Nación, Buenos Aires, 10 dez. 2001. Disponível em: https://www.lanacion.com.ar/357997polemica-por-el-fin-del-proyecto-lusida. Acesso em: 27 ago. 2008.

SANTIAGO, Ariadne. Capacidades burocráticas na prática: um olhar através das lentes dos analistas do licenciamento ambiental federal. 2017. 187 f., il. Dissertação (Mestrado em Ciência Política) - Instituto de Ciência Política, Universidade de Brasília, Brasília, 2017. 
SEWELL, William H. Jr. A theory of structure: duality, agency, and transformation. The American Journal of Sociology, v. 98, n. 1, p. 1-29, 1992. TEIXEIRA, Paulo Roberto. Políticas públicas em AIDS. In: PARKER, R. (org.). Políticas, instituições e AIDS: enfrentando a epidemia no Brasil. Rio de Janeiro: ABIA, Jorge Zahar, 1997.

UNAIDS. Guia de Terminologia do UNAIDS. Brasília: Casa da ONU, 2017. UNAIDS. UNAIDS: the first ten years, 1996-2006. Geneva, Switzerland: Joint United Nations Programme on HIV/AIDS, 2008.

VIANA, Rafael Rocha. Programa Minha Casa Minha Vida - Entidades: um olhar para a ação dos atores em torno das controvérsias. 2017. 147 f., il. Dissertação (Mestrado em Ciência Política) - Instituto de Ciência Política, Universidade de Brasília, Brasília, 2017.

VILAÇA, Luiz. De práticas a capacidades: a atuação de procuradores do Ministério Público Federal no caso de Belo Monte. Soc. e Cult., Goiânia, v. 20, n. 1, p. 61-82, jan./jun. 2017. 


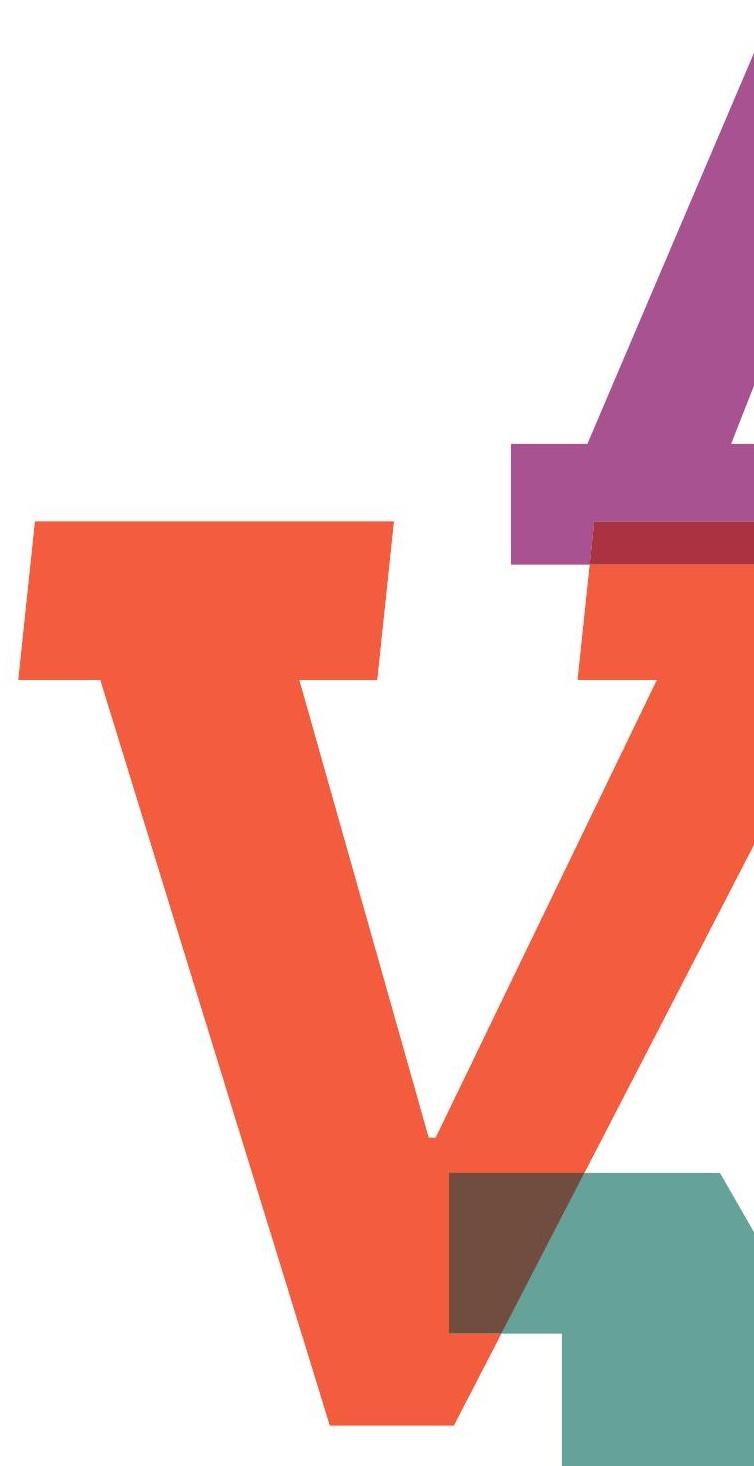




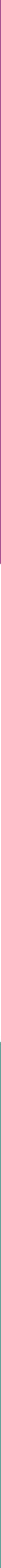




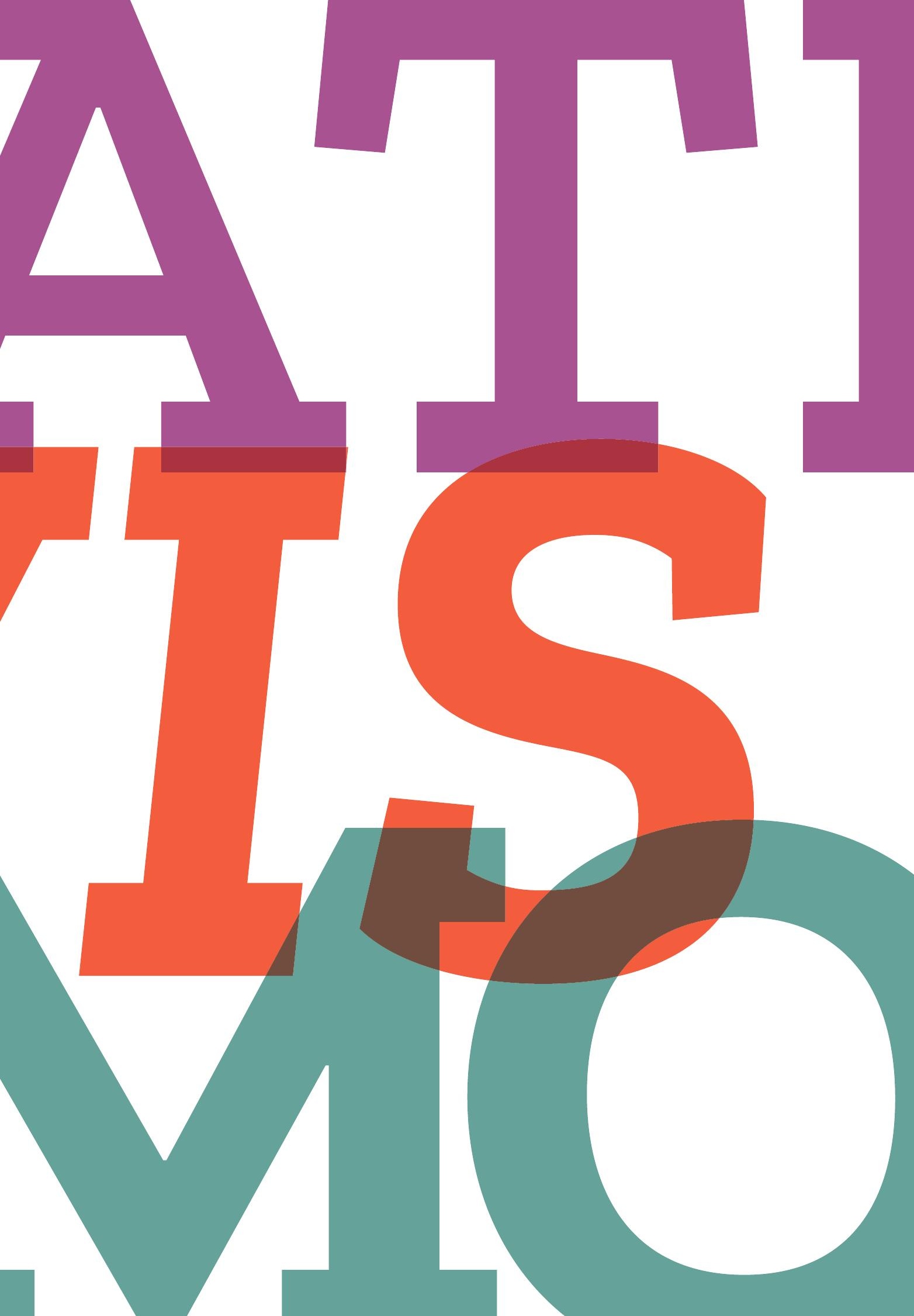




\section{Capítulo 7}

\section{Programa Minha Casa Minha Vida - Entidades: ativismo institucional no acesso à terra urbanizada ${ }^{1}$}

Rafael Viana

\section{Introdução}

Esse capítulo buscará analisar como a interação entre diferentes atores em torno da produção do Programa Habitacional Minha Casa Minha Vida - Entidades o reconfigurou ao longo do tempo. Esse trabalho insere-se em uma agenda de pesquisa em crescimento nos últimos anos que busca avaliar a importância de diferentes atores no processo de formulação, de implementação e de avaliação de políticas públicas, entre eles, notadamente, o papel desempenhado pelos burocratas estatais (ABERS, 2015; LOTTA, 2010;

1 O presente capítulo é resultado parcial da dissertação defendida pelo autor. Para saber mais, ver Viana (2017). 
LOTTA; PIRES; OLIVEIRA, 2014; LOTTA; OLIVEIRA, 2015; PIRES, 2009, 2012, 2015; PIRES; GOMIDE, 2014; CAVALCANTE; LOTTA, 2015).

Nos últimos anos, a análise sobre o processo de produção de políticas públicas tem ganhado destaque em pesquisas acadêmicas, especialmente a partir de abordagens analíticas emergentes que problematizam a dimensão política e relacional da burocracia. Em cenários institucionais complexos, nos quais diferentes burocracias interagem na produção de políticas públicas - relacionando-se, muitas vezes, com atores externos ao Estado -, essas abordagens analíticas emergentes vão chamar atenção para o fato de que a relação entre burocratas e atores externos, muitas vezes, é marcada por intensa negociação, construção de redes, reinterpretações de valores e acomodação de interesses (DUBOIS, 2010; FARIA, 2003; MARQUES, 2003, 2006; LOTTA, 2010; PIRES, 2009; ZITTOUN, 2014). Ainda que sob enfoques analíticos diferentes, esse conjunto de estudos entende que o burocrata, embora limitado por contextos institucionais diversos, possui alguma criatividade para a realização de suas ações cotidianas. Essas abordagens vão destacar o caráter heterogêneo da burocracia, posicionando-se criticamente frente a estudos clássicos com forte natureza normativa que reivindicavam uma noção homogeneizante da burocracia, fundada na concepção weberiana clássica segundo a qual aspectos como, por exemplo, impessoalidade, cumprimento de regras e previsibilidade eram considerados indispensáveis para que o Estado pudesse cumprir a sua função no que diz respeito ao desenvolvimento econômico-social (JOHSON, 1982; LANGE; REUSCHEMEYER, 2005; MOMMSEN, 1989).

No entanto, apesar dos diversos avanços na literatura recente acerca do papel da burocracia na produção de políticas públicas, poucas são as pesquisas, especialmente no Brasil, que dão centralidade à relação entre burocratas de nível federal e atores dos movimentos sociais. Os estudos existentes tendem a focar a interação da burocracia de nível local com os movimentos, conforme revelam o interessante estudo de Penna (2013) sobre a relação entre uma das superintendências do Instituto Nacional de Colonização e Reforma Agrária (INCRA) e os movimentos de reforma agrária, e a pesquisa de Blikstad (2012) sobre a influência do movimento de moradia na implementação da política de habitação do município de São Paulo. Ao identificarmos essa lacuna na literatura, buscamos contribuir para o desenvolvimento de um 
quadro teórico que ajude a explicar o papel da burocracia federal na formulação e na implementação das políticas públicas, levando em consideração a sua interação com atores dos movimentos sociais.

A escolha do Programa Habitacional Minha Casa Minha Vida - Entidades (MCMV-E) como caso a ser estudado mostra-se interessante porque desde a sua concepção, em 2009, o MCMV-E aparece como resultado de uma relação ambígua e complexa marcada pelo conflito, mas, também, pela cooperação entre atores dos movimentos de moradia e burocratas do governo federal inseridos em diferentes organizações estatais em torno da maior política habitacional do governo federal desde a redemocratização, o “Minha Casa Minha Vida” (FERREIRA, 2014; SERAFIM, 2013; ABERS; SERAFIM; TATAGIBA, 2014; JESUS, 2015). O MCMV-E é uma modalidade do Programa Habitacional Minha Casa Minha Vida, programa de subsídio desenvolvido ao longo do ano de 2008 dentro do núcleo decisório do governo federal - Ministério da Fazenda, Ministério do Planejamento e Casa Civil, com a assessoria técnica da Caixa Econômica Federal (CEF) e do Ministério das Cidades (MCidades) - que contava com forte participação do setor da construção civil e apresentava dupla finalidade, a saber: política econômica anticíclica como forma de combater a forte crise econômica internacional de 2008, e redução do conhecido déficit habitacional brasileiro.

Em razão disso, após a imposição desse programa habitacional de maneira "pouco dialogada” (ROLNIK, 2015), vários movimentos sociais de moradia, contando com o apoio de alguns burocratas sensíveis ao problema, pressionaram o governo federal para que suas demandas fossem parcialmente atendidas - alto subsídio financeiro direto do poder público e construção de empreendimentos por meio de entidades organizadoras. Os repertórios de ação utilizados pelos movimentos de moradia foram diversos, como a ocupação de prédios estatais - do MCidades e da CEF em diferentes unidades da federação -, a organização de marchas pela reforma urbana, ou mesmo audiências particulares com a Casa Civil e com a Presidência da República. Foi criado, assim, o Minha Casa Minha Vida - Entidades.

Nesse sentido, a criação do MCMV-E, desde o seu início, será considerada, nesta pesquisa, uma controvérsia dentro do programa "guarda-chuva" Minha Casa Minha Vida. A noção de controvérsia, fortemente inspirada por abordagens pragmatistas francesas, é percebida aqui como diferentes 
entendimentos e posições por parte dos atores acerca de um problema público, ancorados, em geral, em ordens de grandeza ou em racionalidades mais amplas, resultando em diferentes ações em relação ao referido problema, no sentido de estabilizá-lo (BOLTANSKI; THÉVENOT, 1999; LATOUR, 2005; PENNA, 2013; VIANA, 2017). No caso específico em análise, é possível afirmar que, dada a sua natureza, o MCMV-E é uma controvérsia dentro do MCMV, uma vez que a política habitacional construída no núcleo decisório do governo federal possuía uma concepção diferente por parte dos atores envolvidos comparando-se àquela criada pelo MCMV-E.

A fim de compreender o poder de atuação desses atores da burocracia estatal federal com os das organizações nacionais do movimento de moradia em torno do Programa Minha Casa Minha Vida - Entidades, este trabalho buscará responder as seguintes perguntas: i) como essa interação levou à adesão de burocratas a causas defendidas por organizações de movimentos populares?; ii) como a interação entre burocratas federais e atores da sociedade civil levou ao aumento do acesso à terra urbanizada no âmbito do MCMV-E? Argumento que a interação entre burocratas em espaços de negociação formais e informais propiciou a formação de compromissos tanto entre eles próprios quanto entre burocratas e causas contenciosas, como a produção de moradia popular nas cidades brasileiras. Esses compromissos desenvolvidos ao longo de suas trajetórias dentro das arenas estatais e na relação entre os diversos atores, por sua vez, se desdobraram em diferentes práticas no processo de reconfiguração do MCMV-E. Nesse sentido, os achados da pesquisa contribuem para a recente convergência entre a literatura sobre políticas públicas, participação e movimentos sociais no Brasil, qual seja: o compromisso de burocratas com causas sociais nem sempre surge da militância pregressa em organizações de movimentos sociais atuantes no setor de políticas em que trabalham após entrarem para o Estado. No limite, a trajetória dos indivíduos continua a ser desenvolvida após ingressarem para agências estatais, motivo pelo qual defendemos que as arenas estatais são espaços de sociabilidade em torno de pautas mais amplas.

As dinâmicas de conflito e cooperação entre atores de diferentes burocracias e atores de movimentos sociais propiciam a formação de compromissos que não são dados apenas por laços anteriores de pertencimento a organizações 
da sociedade. Essas redes de sociabilidade são fortalecidas - e, em alguns casos, iniciadas - quando esses atores entram para as arenas estatais (VIANA, 2017).

A análise se baseia em entrevistas aprofundadas, documentos e observações de reuniões públicas. ${ }^{2}$ As interlocutoras foram selecionadas por meio da técnica "bola de neve”, com múltiplas entradas ao campo. ${ }^{3}$ Buscamos mitigar, dessa forma, o viés intrínseco a essa técnica pela qual cada interlocutora indica ao final de cada entrevista novos interlocutores para a pesquisa. Atas de reuniões, cartilhas, decretos, editais, termos de referência e leis foram os documentos em que nos baseamos para analisar o caso. A presença em reuniões do Conselho das Cidades também subsidia a análise. Ao valorizar a percepção dos burocratas sobre suas experiências e práticas, a presente pesquisa segue o trabalho de Hallett e Ventresca (2006), Abers e Keck (2013) e Fischer (2016), situando-se na arena epistemológica do interpretativismo na análise de políticas públicas, dedicada à compreensão da ação humana sem descartar a importância do contexto no qual está inserida. Além disso, a análise aqui empreendida privilegia a dimensão processual da política pública, entendendo-a não apenas a partir dos seus efeitos, mas, também, sobre o processo de construção desta ao longo do tempo.

2 Foram realizadas 70 entrevistas com burocratas federais espalhados nas diferentes agências estatais envolvidas com a gestão do MCMV-E. Foi garantido o sigilo sobre a identidade dos interlocutores como maneira de garantir o anonimato de suas declarações, sem prejuízo do conteúdo de suas percepções para a análise. Além disso, foram analisadas todas as publicações relativas ao programa (Leis, Portarias, Decretos e Instruções Normativas publicadas pelo MCidades, e atas do Conselho Nacional das Cidades). Por fim, algumas reuniões dentro do Conselho Nacional das Cidades, no âmbito do Comitê Técnico de Habitação (fórum importante de estruturação da modalidade) foram acompanhadas a fim de compreender a interação dos diferentes atores na construção do programa.

3 A técnica bola de neve com múltiplas entradas foi utilizada a fim de minimizar os vieses de seleção inerentes à técnica. Nesse estudo, as “múltiplas entradas” são caracterizadas como a solicitação de potenciais entrevistados por atores inseridos em diferentes organizações, tais como: Ministério das Cidades, Caixa Econômica Federal, Secretaria do Patrimônio da União, Secretaria da Presidência da República e organizações nacionais do movimento de moradia. Dessa forma, conseguimos mapear uma quantidade de atores elevada, indo para além de subgrupos específicos. 
Destarte, além desta introdução, o presente trabalho está organizado da seguinte maneira. A segunda seção destina-se à discussão teórica, na qual mobilizamos literatura pragmatista de inspiração francesa que valoriza a ação situada dos agentes envolvidos em controvérsias e sua necessidade de justificação dentro dessas disputas. A terceira seção apresentará o caso estudado, o Programa Habitacional Minha Casa Minha Vida - Entidades, tendo como objetivo compreender a finalidade do programa a fim de perceber o papel desempenhado por seus operadores. A quarta seção dedica-se à análise do processo de mudança institucional - regras, instrumentos, processos e estruturas organizacionais estatais - no que diz respeito à disponibilização de imóveis e terras da União Federal no âmbito do MCMV-E a partir de diferentes entendimentos e ações dos atores, sejam da burocracia, sejam dos movimentos sociais. Essa seção mostrará que o papel de mediação política e relacional exercido por esses atores, baseado em experiências anteriores e em ligações a diferentes campos, possibilitou a introdução de importantes inovações no âmbito do MCMV-E. Por fim, nas considerações finais, retomamos o argumento central da pesquisa ao afirmarmos que alguns atores envolvidos com o MCMV-E, após transitarem por diferentes campos ao longo de sua trajetória profissional e pessoal, adquiriram a capacidade de compreender os diferentes atores e interesses em disputa. Isso lhes possibilitou o exercício do papel de mediação entre diferentes regimes em torno das controvérsias relativas ao MCMV-E, resultando, em alguns casos, em mudanças no programa.

2. Relação entre instituições estatais e a sociedade civil organizada: um olhar para ação dos atores nas controvérsias

Até a década de 1980, a literatura sobre movimentos sociais tomava como irrelevante ou até mesmo prejudicial a participação de militantes dos movimentos sociais dentro do Estado. Algumas literaturas questionavam a participação desses atores dentro do Estado pois entendiam que, a fim de garantir uma atuação autônoma por partes dos movimentos, esses atores deveriam permanecer longe da esfera estatal (COHEN; ARATO, 1992). Havia, nesse sentido, a noção de que a interação entre os atores externos 
ao Estado e os burocratas estatais poderia ser prejudicial aos primeiros, reduzindo sua efetividade.

No entanto, em anos mais recentes, a literatura sobre movimentos sociais tem se preocupado em expandir seus horizontes, tanto empírica quanto teoricamente. Essa nova abordagem entende que há diversas formas de interações empregadas pelos movimentos sociais - a interação entre os atores dentro e fora do Estado seria uma delas (ABERS; VON BÜLOW, 2011; ABERS; SERAFIM; TATAGIBA, 2014).

O conceito de "ativismo institucional” emerge dessa discussão recente sobre os "novos movimentos sociais" e as interações dos ativistas desses movimentos dentro e fora do Estado (ABERS; TATAGIBA, 2015; ABERS; SERAFIM; TATAGIBA, 2014; ABERS; VON BÜLOW, 2011). Buscando superar uma visão dicotômica entre o Estado e os movimentos sociais, alguns estudos importantes entendem que é necessário compreender a relação imbricada entre essas duas esferas. Para Abers e Von Bülow (2011, p. 54), “as fronteiras organizacionais da nossa unidade de análise não deveriam ser definidas a priori, mas sim pelo formato das redes de ação coletiva que existem na prática”. As autoras, portanto, salientam a importância de se compreender as diversas formas de interação entre os movimentos sociais e o Estado.

É a partir dessa discussão que o conceito de "ativismo institucional" ganha destaque, tomado por empréstimo neste trabalho a fim de compreender a interação entre os burocratas e os atores da sociedade civil atuantes no Programa Minha Casa Minha Vida - Entidades. O conceito, inicialmente apresentado por Abers e Tatagiba (2015, p. 73, tradução nossa), é definido como "o que pessoas fazem quando assumem cargos em burocracias governamentais com os propósitos de fazer avançar agendas políticas ou projetos propostos por movimentos sociais". ${ }^{4}$ No entanto, tendo em vista a investigação deste trabalho, adotaremos a nova definição trazida pela autora sobre ativismo institucional (ABERS, 2015), abarcando a ação do

4 "[...] what people are doing when they take jobs in government bureaucracies with the purpose of advancing the political agendas or projects proposed by social movements." (ABERS; TATAGIBA, 2015, p. 73). 
burocrata que tenha como objetivo perseguir um compromisso público mais amplo - no caso em análise, compromissos voltados à reforma urbana -, ainda que esse burocrata não tenha ligação direta com um movimento específico (ABERS, 2015, p. 148). O intuito desta pesquisa é contribuir para a construção desse conceito.

A fim de entender como se dá a interação entre agentes no nível micro, levando em consideração a percepção e o posicionamento desses na produção do MCMV-E em sua ação cotidiana para dentro e para fora de suas organizações, consideramos que mobilizar a lente pragmatista francesa nos é útil uma vez que essa abordagem tem um olhar privilegiado para situações nas quais diferentes atores se juntam, experimentam, negociam e convergem, materializando possíveis acordos em instituições e/ou estruturas. Nessa perspectiva, a dimensão micro recebe um olhar especial do pesquisador sem que se oponha às dimensões meso ou macro, uma vez que estas são concretizadas e realizadas por meio "das práticas, dos dispositivos e das instituições, sem os quais elas existiriam, mas não poderiam mais ser vistas e descritas” (BARTHE et al., 2016, p. 88).

Para Cefaï (2009, p. 28), os

sentidos que os atores agregam às suas próprias ações [...] ou a definição dos atores para a suas próprias situações [...] continuam como campo último do cientista social. As perspectivas dos pesquisadores devem ser devedoras em relação às dos atores.

Dentro dessa abordagem, a ação dos atores é, de fato, “levada a sério”, considerando seus argumentos e as provas que proporcionam sem tratar de reduzi-los ou de desqualificá-los por meio da oposição de uma interpretação mais forte (BOLTANSKI, 2000, p. 55). A expressão ser levado a sério, nesse caso, significa para o pesquisador "seguir de perto os atores e o seu trabalho interpretativo, abrindo caminhos por meio da crítica produzida por eles” (PENNA, 2013, p. 125). Consiste em realçar, portanto, o engajamento situado dos atores, acompanhando suas experiências e posições. É nesse sentido que afirmamos que essa vertente, além de nos subsidiar com elementos teóricos importantes, também nos oferece amparo metodológico para a realização da presente pesquisa, uma vez que nos apresenta maneiras 
pelas quais podemos alinhar, de maneira integrada, o rastreamento da ação dos atores e a competência crítica desses na produção e na utilização do conhecimento para intervir na realidade social que os cerca.

A partir de ferramentas teórico-metodológicas trazidas por sociólogos pragmatistas franceses, adotaremos o conceito de controvérsia como uma chave analítica importante a fim de compreender a ação dos diferentes atores no processo de construção do Minha Casa Minha Vida - Entidades. As controvérsias ou disputas, conforme apontado por Penna (2013), Latour (2005), Boltanski (2000) e Viana (2017), são objetos de análise singulares, pois possibilitam ao analista social compreender de maneira aprofundada os elementos que influenciam para que os atores ajam de determinadas maneiras. Para Latour (2005), em situações de controvérsias, os atores tendem a apresentar argumentos e provas perante as outras pessoas a fim de legitimar as suas posições. Essas provas, conforme apontado por Boltanski e Thévenot (1999), são dispositivos sobre os quais os agentes ancoram suas posições - como, por exemplo, leis, resoluções, princípios éticos e morais -, associados a ordens de grandeza maior. Segundo Penna (2013, p. 353), “em situações de disputa, as pessoas tendem a apresentar argumentos e justificativas para suas opiniões, revelando o que as faz agir de determinada forma”. Em geral, essas posições estão lastreadas em ordens de grandeza ou em quadros de referências mais amplos. As competências críticas desses atores são entendidas como manifestação de seu poder de agência diante dos momentos de disputa. Nesse sentido, as controvérsias e os momentos de crise oportunizam ao analista social a compreensão sobre o processo de construção do social, não por sua reprodução, mas pela reflexão realizada pelos atores, ocasionando a integração entre o micro e o macro pelo exercício crítico interpretativo dos agentes. Assim, ao identificarmos o questionamento destes ao coletivo e às formas de reparação colocadas em prática a partir da crítica da ordem, da justificação, da legitimação e da reconstrução da ordem (do desarranjo ao rearranjo), conseguimos compreender a atuação situada dos atores no processo de produção da política pública.

No caso do processo de mudança do Minha Casa Minha Vida - Entidades aqui analisado, entendemos que essa escolha é adequada uma vez que ela permite compreender as concepções, posições e ações de burocratas federais inseridos em diferentes organizações em relação a temas com os 
quais lidam cotidianamente enquanto exercem suas atividades em torno do cumprimento desse programa federal. É uma possibilidade analítica de olhar para as ações dos atores (nível micro), inseridas em uma dimensão meso dentro da política, em interação com outros atores, sejam estatais, sejam da sociedade civil. É uma oportunidade de compreender como esses atores envolvidos nas controvérsias subsidiárias relativas ao MCMV-E, mobilizam recursos e estratégias a fim de estabilizá-las, buscando a construção de acordos com diferentes agentes, os quais, em alguns casos, resultaram em mudanças nos normativos e nas estruturas organizacionais relativas ao programa. É, por fim, a oportunidade de se destacar a heterogeneidade presente dentro das agências estatais, realçando a natureza diversa do corpo burocrático envolvido com a política pública.

Ao olharmos para o processo de mudança institucional do Minha Casa Minha Vida- Entidades (MCMV-E) desde a sua criação, é possível identificar alguns problemas públicos sobre os quais os diferentes atores, sejam da burocracia, sejam da sociedade civil, se debruçavam, problemas que levaram a mudanças - regras, instrumentos, processos e arranjos institucionais - em relação à modalidade. A partir da percepção dos próprios atores entrevistados, da observação de algumas reuniões e da análise de diversos documentos relativos ao programa, identificamos um problema-chave advindo da implementação da modalidade que será o foco de análise deste capítulo: o acesso à terra urbanizada e imóvel para construção dos empreendimentos (VIANA, 2017). A diferente gramática subjacente ao projeto autogestionário estará permanentemente em disputa no processo de produção da modalidade. A partir dela se reivindica o protagonismo da sociedade civil na produção da política em disputa com o programa MCMV "guarda-chuva”, marcado pela gramática da eficiência segundo a qual a relação de proximidade com empresas da construção civil é a ordem. Nesse sentido, na operacionalização cotidiana do MCMV-E é possível perceber diferentes posições e ações dos atores envolvidos acerca de alguns problemas públicos, justificando, mais uma vez, a potencialidade dessa ferramenta teórica-analítica.

Inspirado na abordagem pragmatista, o conceito de "mediação” torna-se chave para compreendermos como a ação dos atores da sociedade civil e da burocracia tem efeito recíproco uns sobre os outros em torno da operacionalização do MCMV-E. Para Latour (2005, p. 39), os mediadores, mais do que 
simples intermediários transportadores de ideias, significados e ações já existentes sem o desejo de modificá-las, são agentes que se ligam a outros provocando impactos sobre estes ou modificando a condição anterior. “Os mediadores transformam, traduzem, distorcem e modificam o significado ou os agentes com os quais eles se veiculam” (LATOUR, 2005, p. 39, tradução nossa). ${ }^{5}$ No papel de mediadores, esses atores permanentemente transportam e traduzem informações tanto para dentro de suas próprias organizações quanto para fora delas, causando efeitos tanto sobre as próprias organizações quanto sobre os agentes envolvidos com a operacionalização da política pública (PENNA, 2013). No caso do MCMV-E, é possível dizer que alguns burocratas envolvidos com a gestão do MCMV-E, em razão de suas experiências anteriores em programas habitacionais autogestionários, nos quais a interação com atores da sociedade civil foi bastante intensa, adquiriram a capacidade de transitar por diferentes regimes ou mundos, fazendo esse papel de tradução entre as diferentes linguagens e concepções em torno da produção social de moradia.

Outra ferramenta teórico-analítica importante oferecida por essa abordagem é a noção da sociabilidade dentro das arenas públicas (CEFAÏ, 2009) ou dos fóruns híbridos (CALLON et al., 2009). De acordo com Cefaï (2009, p. 22), as arenas públicas e as suas organizações constitutivas são caracterizadas por um “'embaralhado', ‘misto’ e 'híbrido’” de modalidades de engajamento, com diferentes lógicas de racionalidade e de legitimidade que se cruzam em seus cursos de ação. Essas arenas podem

desempenhar o ofício de meio de sociabilidade, produzindo o entre-si, facilitando os encontros, catalisando as simpatias e garantindo as solidariedades, forjando experiências comuns que podem ir até a comunidade de destino. (CEFAÏ, 2009, p. 23).

Já para Callon et al. (2009, p.18), fóruns híbridos são definidos como locais abertos de participação e de reconhecimento entre diferentes atores, nos quais se discutem questões técnico-políticas que envolvem o coletivo.

5 "Mediators transform, translate, distort, and modify the meaning or the agents in which they are transmitted” (LATOUR, 2005, p. 39). 
Nesse tipo de espaço, marcado pela incerteza e pela disputa, um dos papéis importantes dos atores na ação pública é o de construção de sentidos, ao realizarem a função de tradução entre múltiplas gramáticas. Essas ferramentas são ricas para o caso aqui analisado uma vez que, dada a heterogeneidade dos atores participantes do MCMV-E, elas possibilitam compreender como se dá a construção de sentido desses atores em interação, expandindo seus horizontes de experiência e de saberes e suas concepções sobre pautas sociais mais amplas, algo que, em atuação isolada, seria improvável de acontecer. Assim, um dos argumentos deste estudo, ancorado nas experiências dos próprios atores envolvidos com o programa, é o de que a criação de alguns espaços dentro da estrutura estatal a fim de negociar soluções sobre as controvérsias no processo de produção do MCMV-E permitiu a sociabilidade no que diz respeito a compromissos sociais mais amplos voltados ao direito à moradia e à cidade. Como será observado mais à frente, alguns atores passam a construir compreensões mais gerais sobre o direito à moradia e à cidade no momento em que, ao entrarem para o Estado, começam a participar de determinados espaços nos quais essas controvérsias e as diferentes posições em torno delas estão presentes. Tais construções de sentidos vão influenciar as formas de agir e se posicionar desses atores frente aos problemas. Esse entendimento, de certa maneira, dialoga com o conceito de ativismo institucional e amplia a sua compreensão, uma vez que permite pensar em um ativismo sendo forjado após o ingresso para o corpo burocrático. A partir do caso em análise argumentamos que, a fim de compreender os elementos que impactam a ação do indivíduo, a trajetória dos atores após sua incorporação ao corpo estatal deve ser levada em conta, uma vez que o Estado é um espaço de sociabilidade política.

Em resumo, essa abordagem permite destacar o papel de mediação exercido pelos atores no processo de mudança do MCMV-E, resultado de práticas discursivas e de experimentação como uma atividade de "colagem ou cimentação” (ZITTOUN, 2014, p. 10, tradução nossa) ${ }^{6}$ com a qual eles acionam outros atores inseridos em outras organizações a fim de buscar soluções para as controvérsias em torno do programa. Conforme apontado

6 “[...] 'gluing' or 'cementing' processes” (ZITTOUN, 2014, p. 10). 
por Zittoun (2014), apresentar uma solução não significa necessariamente que ela será implementada, uma vez que há diferentes atores lutando com propostas de diferentes soluções. Ou seja, esse processo não é natural ou óbvio, como algumas análises sobre políticas públicas tendem a considerar. Assim, nesse caso, é importante compreender como essa propagação de soluções ocorre por meio da construção de coalizão de atores. O acionamento de diferentes atores e campos não é estático, dependendo do problema a ser enfrentado. Portanto, diferentes campos - seja da sociedade civil, seja de uma determinada carreira de serviço público, seja do campo de especialistas como o da Reforma Urbana - podem ser mobilizados de diversas maneiras pelos atores envolvidos, o que torna a noção de campo bastante fluida e dinâmica (CEFAÏ, 2009; BOLTANSKI; THÉVENOT, 1999) e a diferencia de outras abordagens que tendem a compreender os campos, especialmente do Estado e dos Movimentos Sociais, como separados e fixos.

\section{Minha Casa Minha Vida - Entidades}

O Programa Minha Casa Minha Vida - Entidades, criado a partir da publicação da Lei n ${ }^{\circ}$ 11.977, de 7 de julho de 2009, é uma das modalidades do PMCMV e tem como objetivo tornar a moradia acessível às famílias de baixa renda, com renda bruta mensal de até R\$1.600,00 (BRASIL, 2009). Essa modalidade, além de priorizar um público-alvo com menor renda, se diferencia do PMCMV por dois princípios importantes ligados à pauta urbana, a saber: o subsídio direto do poder público à construção da moradia e a autogestão (FERREIRA, 2014).

O primeiro princípio diz respeito ao subsídio parcial direto do poder público às famílias de baixa renda, a partir de recursos oriundos do Orçamento Geral da União (OGU) repassados ao Fundo de Desenvolvimento Social (FDS). Trata-se de uma reivindicação que sempre esteve presente na pauta dos movimentos de moradia, que entendem que o montante do financiamento não deve estar associado à capacidade de pagamento, mas à necessidade habitacional (MINEIRO; RODRIGUES, 2012). O segundo princípio se refere à autogestão, que concede um papel central às “entidades organizadoras” cooperativas habitacionais, associações e demais entidades privadas sem fins 
lucrativos - no sentido de dar poder a essas entidades para organizar as famílias em torno da construção da moradia. Essa autogestão se manifesta por meio da construção do projeto a ser aprovado pelo poder público, da obtenção do financiamento, da construção das moradias e da entrega das casas, o que, em tese, estimularia o cooperativismo e a intensa participação das famílias como protagonista na construção da política habitacional. ${ }^{7}$ Embora essa modalidade seja considerada uma conquista pelos movimentos ligados à pauta urbana, uma vez que, conforme discutido anteriormente, dá centralidade ao papel da autogestão e do financiamento público da moradia, ela corresponde a apenas 1\% do total de habitações do programa, assumindo um caráter residual (FERREIRA, 2014; MINEIRO; RODRIGUES, 2012) no MCMV. Isso revela a fragilidade que a modalidade apresenta dentro da Política Habitacional do Governo e as disputas, inclusive dentro do Ministério das Cidades, para que o MCMV-E continue a fomentar a inclusão de setores sociais vulneráveis à moradia digna. É dentro desse contexto de disputas que a próxima seção tentará compreender o papel desempenhado pelos burocratas ligados à mudança institucional dessa política pública.

\section{Ação dos burocratas na construção do MCMV-E}

O programa Minha Casa Minha Vida - Entidades emergiu no contexto de implantação do Programa de Aceleração do Crescimento (PAC) durante o segundo mandato do ex-presidente Lula (2007-2010). Conforme já pontuado em seção anterior, o programa surgiu da articulação entre burocracias da administração direta e da administração indireta, em resposta a demandas de organizações de movimentos sociais. As principais burocracias envolvidas inicialmente no MCMVE foram o Ministério das Cidades e a Caixa Econômica Federal. O programa se transformou ao longo do tempo, passando a contar com a participação de outras burocracias federais em sua gestão. Nesta seção, mostramos como burocratas perceberam sua atuação na emergência do programa.

7 Há, no entanto, diversos estudos que apontam para uma “lógica de mercado” na relação entre as entidades e as famílias. Ver Lago (2011). 
A criação do MCMV-E foi resultado de diferentes pressões de ativistas de organizações nacionais de movimentos de moradia. Atores ligados ao campo da moradia demandavam que uma parte do MCMV geral fosse destinada à construção de habitações de interesse social, formato no qual entidades sem fins lucrativos teriam protagonismo na gestão do programa.

A fim de que a demanda entrasse na agenda do governo federal, organizações do movimento de moradia ocuparam o edifício sede da Caixa Econômica Federal (CEF), em Brasília, como repertório de ação para negociar a existência do programa e forçar a Presidência da República e a Casa Civil a assumirem o compromisso público de criação de uma modalidade com essa natureza. Mas, para que o programa pudesse efetivamente ser institucionalizado, o apoio de burocratas em diferentes organizações foi importante, no sentido de desenhar o formato financeiro-operacional de modo a superar os problemas de experiências anteriores.

Ainda que o perfil dos servidores públicos federais espalhados nas diferentes organizações envolvidas com a gestão do MCMV-E seja preponderantemente sem trajetória anterior em organizações do movimento de moradia, há um entendimento comum dentro do Ministério das Cidades e da unidade matriz da Caixa Econômica Federal de que o projeto político-organizativo do MCMV-E advém de experiências municipais no final da década de 1980 e início da década de 1990, a partir das quais se compreende que projetos autogestionários habitacionais poderiam efetivamente transformar-se em política pública.

Além da percepção de que o projeto autogestionário subjacente ao MCMV-E emerge da experimentação no nível municipal como alternativa para resolver um problema público de déficit habitacional para populações de baixa renda, vários burocratas federais entendem que o modelo financeiro-operacional do Entidades, no momento de sua criação em 2009, foi resultado do aprendizado com outras experiências já realizadas no âmbito federal, notadamente o Programa Crédito Solidário (PCS) e o Programa Social de Moradia (PSM). Esses programas, criados respectivamente em 2004 e 2008, também tinham as entidades organizadoras como protagonistas no processo de produção habitacional. No entanto, esses programas tiveram diversas dificuldades de operacionalização devido à sua natureza inovadora, principalmente no que se refere ao repasse financeiro-orçamentário às entidades. 
Nesse sentido, um dos papéis desempenhado por parte da burocracia situada no MCidades à época da reivindicação das organizações nacionais do movimento de moradia pela criação de um programa autogestionário dentro do grande pacote habitacional recém-lançado foi o de desenhar, juntamente com técnicos da Caixa Econômica Federal da unidade matriz e alguns militantes com grande trajetória em política habitacional, um modelo inicial que já partisse de um aprendizado, especialmente do que não dera certo nas experiências anteriores, a fim de que se tivesse um programa de habitação de interesse social "menos travado, mais rodável” (Entrevistada 20, Caixa Econômica Federal). Essa tarefa, segundo os entrevistados, exigiu grande poder de negociação, especialmente em sua atuação dentro dos grupos técnicos do Conselho Curador do Fundo de Desenvolvimento Social (CCFDS) a fim de traduzir as demandas das principais organizações em normas com viabilidade dentro da administração pública federal. Essa modalidade autogestionária, embora tenha sido reivindicada nas semanas que antecederam o lançamento do MCMV e já fosse conhecida naquela ocasião, será oficialmente criada apenas cinco meses depois com a publicação da Resolução do CCFDS, nº 141, de 10 de junho de 2009.

Observa-se, neste sentido, conforme mobilizado na seção teórica, um forte papel de mediação político-relacional de alguns burocratas federais envolvidos com a modalidade, na tentativa de traduzir uma demanda da sociedade civil em uma linguagem defensável dentro da administração pública federal. Esse papel, conforme as narrativas dos próprios atores envolvidos atestam, foi desenvolvido ao longo de suas trajetórias, tendo dois elementos acionadores: i) experiência com programas autogestionários em outros níveis da federação; e ii) formação em urbanismo, a partir da qual tiveram contato com organizações dos movimentos sociais, compreendendo suas demandas. Conforme será discutido na próxima seção, aprendizado e experiência também serão mobilizados a fim de que terras urbanizadas sejam destinadas aos empreendimentos construídos no âmbito do MCMV-E. 


\subsection{A ação dos burocratas na reformulação do MCMV-E: o problema de acesso à terra urbanizada}

Inúmeros desafios perpassam o desenho e a implementação do MCMV-E. Além do esforço de traduzir as demandas de organizações de movimentos sociais para os parâmetros de entendimento sobre direito administrativo de diferentes burocracias, burocratas também precisam lidar com desafios surgidos no processo de implementação dos programas. Nesta seção, analisamos a percepção de burocratas sobre sua participação na criação de soluções para problemas e desafios decorrentes da implementação do MCMV-E no que diz respeito ao acesso à terra urbanizada para a construção dos empreendimentos.

Os burocratas encarregados de operacionalizar o MCMV-E tiveram que enfrentar diversos desafios para que os programas "saíssem do papel”. Esses desafios podem ser reunidos em duas categorias, quais sejam: problemas públicos surgidos ao longo da implementação do programa, especificamente no tocante ao acesso à terra urbanizada; e resistências burocráticas oferecidas à execução dos programas dentro das próprias agências estatais participantes do arranjo. Abordamos a seguir a primeira categoria de controvérsias que se relacionam à atuação de burocratas na mudança dos programas e deixamos a segunda categoria para a seção seguinte, pois nos permitirá também abordar o processo de conversão de burocratas às causas defendidas pelos movimentos sociais envolvidos em cada programa.

O vultoso montante investido e o número de unidades habitacionais projetadas por uma política pública habitacional como o MCMV tiveram grande impacto no espaço urbano e no mercado imobiliário, dificultando o acesso à terra urbanizada. A elevação do valor da terra para a construção de empreendimento habitacional nos centros urbanos gerou sérios obstáculos para que as entidades organizadoras pudessem "tocar os seus projetos”, especialmente no que se refere ao maior tempo da obra. Provocados por conselheiros das organizações nacionais do movimento de moradia atuantes

8 Termo frequentemente utilizado pelos atores envolvidos com a gestão do programa para denotar a dificuldade de operacionalização, inclusive interna às organizações estatais. 
no Conselho Nacional das Cidades, ${ }^{9}$ burocratas situados no MCidades, na CEF e na Secretaria do Patrimônio da União (SPU) decidem articular, de dentro de suas agências, soluções para minimizar o problema do acesso à terra urbanizada de duas maneiras: $i$ ) alterar a regulamentação do programa, prevendo a possibilidade de antecipação de recursos para compra de terrenos; e ii) articular a destinação de terras e imóveis da União para projetos de habitação de interesse social.

A antecipação de recursos era defendida veementemente pelos coletivos sociais, mas tinha bastante resistência dentro das agências estatais - especialmente no MCidades e na CEF -, uma vez que invertia a ordem vigente de contratação no setor público, segundo a qual primeiro se constrói a obra/produto e depois se descentraliza o recurso financeiro. Nesse sentido, contar com a participação de burocratas dispostos e capazes de traduzir a demanda dos atores societais para uma "roupagem" minimamente aderente ao campo da administração pública federal foi fundamental para que essa mudança fosse implementada. A construção da solução teve forte interação tanto entre aqueles que defendiam a proposta - em geral, técnicos com experiência em programas de habitação de interesse social - quanto com aqueles que mostravam resistência à solução apresentada. Após intensa negociação entre tais atores ficou estabelecida então, por meio da portaria 143, uma nova modalidade no programa, popularmente conhecida como "Compra Antecipada de Terrenos”, que previa a antecipação de recursos para as EOs com vistas à elaboração de projetos, à compra de terrenos e às despesas com legalização. Essa é uma das mudanças mais importantes no MCMV-E.

Diante do problema de acesso das entidades à terra urbanizada para construção de habitação de interesse social, burocratas situados na SPU e participantes do Conselho Nacional de Cidades decidiram criar um grupo de trabalho nacional com a finalidade de mapear os imóveis e as terras da União aptos a tal destinação, a fim de disseminar a gestão democrática do patrimônio. Segundo os entrevistados, a criação desse grupo teve forte

9 Mais especificamente, dentro da Câmara Técnica de Habitação (CTH), unidade temática na qual se discutiam questões relativas ao MCMV, com forte participação de conselheiros ligados às organizações nacionais do movimento de moradia. 
apoio da Secretária Nacional do Patrimônio da União e veio de uma proposta construída no âmbito do Concidades resultante da interação entre atores do campo da moradia, ONGs com atuação na reforma urbana e de servidores da SPU nacional, da CEF e do MCidades.

O GTN era composto por esses segmentos, junto a representantes de estados, municípios e empresários a fim de que fosse garantida a diversidade de representações, conforme observado na composição do Concidades. Segundo a secretária da SPU à época, a constituição desse GTN tinha como objetivo dinamizar o processo de identificação de imóveis e de terrenos da União para Habitação de Interesse Social (HIS), dada a ausência de um banco de terras do governo federal e da fragilidade do corpo burocrático em operacionalizar essa política. Era, ainda de acordo com a então secretária, o reconhecimento de que os órgãos estatais não eram capazes de realizar essa atividade sozinhos, necessitando da expertise de atores da sociedade civil, especialmente das organizações do movimento de moradia que tinham essa bandeira como uma de suas principais. A criação do GTN - e dos respectivos grupos de trabalhos estaduais (GTEs) - aumentou a destinação de imóveis e terras da União para habitação de interesse social, mostrando que a atuação de atores burocráticos por dentro da arena estatal, a partir de uma concepção ampliada sobre a função social da moradia e contando com o apoio de atores extraestatais, foi importante para que essa política fosse implementada.

Observa-se, neste sentido, que uma das funções importantes desempenhadas por parte da burocracia federal dentro da SPU foi a de disseminação ideacional a fim de diminuir as resistências presentes na implementação da modalidade. Para além dessa função, os burocratas da unidade central da SPU ainda exerciam uma importante atribuição de articulação. Essa articulação, fortemente marcada pelo seu aspecto relacional, caracteriza-se pela mobilização de atores de outros órgãos estatais, com os quais se compartilham valores e crenças em torno da habitação de interesse social, formando-se uma espécie de coalizão a fim de superar problemas emergentes, especialmente no que concerne a conflitos fundiários e projetos habitacionais paralisados no nível local. As falas a seguir, de dois dos entrevistados com atuação na SPU, explicitam a mobilização de atores inseridos no MCidades e na CEF a partir de uma relação de proximidade 
e de afinidade com a política, com vistas a “destravar” demandas relativas à destinação de mobiliário para HIS:

Atuando no GT nacional, muitas vezes, a gente fazia negociações a fim de destravar entraves localizados na ponta. Às vezes, por uma questão de má vontade da superintendência ou de escasso funcionamento de um GTE, a gente fazia videoconferências com esses entes locais para superar algum obstáculo. Quase sempre, essas videoconferências, estabelecidas a partir daqui da unidade central, contavam com a participação de servidores da Caixa, do MCidades e Presidência. Em geral, como tínhamos uma relação de proximidade, pois já nos conhecíamos de outros trabalhos, inclusive, quando eu ainda não era daqui da SPU - a X [nome omitido para preservar o anonimato], do MCidades, por exemplo, a gente já tinha trabalho juntos na criação da lei de regularização fundiária - e tínhamos uma posição de coordenação ou gerência nos nossos órgãos, o que facilitava por reunirmos informações importantes sobre o processo, então a gente conseguia gerenciar as equipes para tentar mediar algum conflito. (Entrevistada 26, SPU).

Então, essas pessoas que você citou, X, Y, Z, W [nomes omitidos para preservar $\mathrm{o}$ anonimato], a gente atuava muito em parceria, são amigas de longa data, tudo gente fina. A gente tinha uma relação muito próxima da Caixa, da secretaria geral da presidência, do pessoal do Ministério das Cidades. Então, dentro da própria SPU, a gente contava também com o apoio desse pessoal, aí gente fazia isso aí a várias mãos, que a SPU tem uma característica, por ser um órgão descentralizado, nem sempre o superintendente da vez, em razão da coalizão governamental, nem sempre ele comungava das ideias, das diretrizes que o órgão central passava. Então a gente tinha que ficar o tempo inteiro reafirmando e reafirmando também por não só, por meio de uma cobrança de autoridade, mas por meio de formação e sensibilização, da importância desse programa dentro da SPU e dentro da Minha Casa Minha Vida. (Entrevistado 28, SPU). 
Essa relação de proximidade ou de afinidade, conforme destacada nas falas anteriormente citadas, também foi citada por outros atores envolvidos com o programa, o que dialoga com a noção de "agência situada” de Bevir e Rhodes (2010), a partir da qual os indivíduos, interagindo socialmente, inseridos em um tecido de crenças e de concepções acerca da política habitacional de interesse social, são capazes de agir para mobilizar essas concepções com vistas a alterar os contextos sociais e os arranjos institucionais nos quais estão inseridos. Dialoga, ainda, com estudos brasileiros recentes sobre implementação de políticas com arranjos interorganizacionais, os quais, de maneira geral, destacam que a mobilização de atores, a partir de redes de confiança ou de compartilhamento de compromissos, possibilita a mínima coordenação da política pública a fim de que esta seja operacionalizada, dada a sua natureza inerentemente difusa (LOTTA; OLIVEIRA, 2015; PIRES; GOMIDE, 2016; PIRES, 2015).

Em resumo, a partir das diferentes concepções dos atores em torno da controvérsia discutida nesta seção, é possível dizer que esses agentes têm empreendido diferentes ações a fim de implementar mudanças quanto à disponibilização de terra urbanizada para habitação de interesse social. Essas mudanças, conforme apresentado, estão relacionadas a alterações nos normativos estruturantes do programa, à criação de espaços híbridos de concertação relativos à destinação do mobiliário da União para fins de HIS e a novas formas de se perceber o problema construídas em interação com outros atores envolvidos com a política. Em relação aos atores no interior da burocracia, verifica-se que esses agentes, com certo protagonismo daqueles situados na SPU, exerceram uma variedade de papéis - disseminação, mediação e tradução - a fim de que determinadas mudanças fossem realizadas. Quanto ao papel de negociação, destaca-se a atuação desses atores na alteração de algumas leis relativas à efetivação de instrumentos - como a CDRU e a CUEM - com vistas à destinação de imóveis para fins de HIS. Associado a esse papel estava o de tradução, a partir do qual alguns agentes, fundamentados em concepções mais amplas sobre a HIS em interação com atores do movimento de moradia e da reforma urbana, tentaram adaptar algumas das demandas e propostas apresentadas por esses agentes em formatos que fossem passíveis de serem defendidos nos espaços aos quais esses agentes não tinham acesso - como na Casa Civil e na Conjur do órgão - segundo as regras da Administração Pública. Essa função de tradução, 
conforme pontuado na seção teórica deste capítulo, assemelha-se, de certa maneira, à noção de “tradução” ou de “mediação” proposta por Latour (2005) e salientada no trabalho de Penna (2013), que exige dos atores a competência de circularem por "diferentes mundos” a fim de operacionalizar associações entre os diversos agentes, o que, no caso em análise, segundo a percepção dos atores envolvidos, parece ter tido efeito na execução da política.

Baseado na realização de diversas atividades formativo-interativas (seminários, oficinas, cursos de curta duração) e na criação de espaços de concertação (GTN e GTEs) com a participação de diferentes atores no processo de identificação e de destinação de imóveis para fins de HIS, observa-se que o papel de disseminação foi relevante na tentativa de expandir a concepção dos burocratas da SPU sobre a missão do próprio órgão, a qual, para além da questão arrecadatória, deveria estar fundada na função socioambiental com vistas a minimizar as resistências desse corpo burocrático na destinação do mobiliário para HIS. As criações do GTN e dos GTEs, segundo a percepção dos atores envolvidos, são de particular importância porque, para além da discussão sobre aspectos operacionais relativos à destinação, eram espaços de construção coletiva de percepções acerca do problema da questão fundiária urbana. Neles, era possível conhecer a percepção dos outros atores envolvidos com a temática, observação que se aproxima daquela proposta por Callon, Lascoumes e Barthe (2009) acerca de “fóruns híbridos” quando afirmam que, em determinados espaços marcados pela incerteza e pela disputa, um dos papéis importantes dos atores na ação pública é o de construção de sentidos. Era, também, o reconhecimento de que a agência estatal, sozinha, não era capaz de atacar a identificação de terras e imóveis com perfil para HIS. Nesse caso, o papel desempenhado pela secretária da SPU à época foi percebido por atores externos ao órgão como um trabalho exitoso no qual essa atriz - em razão da trajetória pessoal-profissional anterior e, consequentemente, pelo compartilhamento de concepções mais gerais acerca da HIS - mobilizou atores externos para realizar mudanças no interior do órgão, o que, em nosso entendimento, dialoga com a noção trazida por Abers (2015, p. 148) acerca do ativismo burocrático. Em seu estudo, Abers destaca que alguns agentes no interior da burocracia buscam implementar mudanças dentro do Estado ao perseguir um compromisso 
público mais amplo, inclusive por meio da mobilização de atores externos, como se revela em nosso caso.

Além disso, esses cursos de capacitação e a constituição de grupos de trabalho com a participação de atores da sociedade civil, se compreendidos segundo uma abordagem pragmatista, que tende a enfatizar o papel dos elementos que compõem as redes sociotécnicas na produção do social (LATOUR, 2005; LASCOUMES; LE GALÈS, 2012), podem ser considerados instrumentos importantes com vistas à estabilização de uma nova ordem. Em outras palavras, na tentativa de disseminarem internamente uma nova racionalidade fundada na função social do mobiliário da União em contraposição a uma racionalidade baseada estritamente na função arrecadatória, os burocratas da SPU estão, na verdade, criando instrumentos ou dispositivos para superar essas resistências internas e reconstruir a ordem, ainda que momentaneamente, em torno dessa controvérsia. Ou seja, esses atores, a partir da criação de instrumentos - no caso, jurídicos, organizacionais e formativos - buscam estabilizar concepções em torno da função social da propriedade, (re)construindo legitimidade para soluções após a crítica.

\section{Considerações finais}

O presente estudo teve como objetivo compreender como os atores envolvidos com a produção do programa Minha Casa Minha Vida - Entidades no nível federal agiram em torno da controvérsia relativa à destinação de terras e imóveis da União para Habitação de Interesse Social. Esses atores, apesar de inseridos em diferentes organizações e a partir de diferentes entendimentos, posições e percepções sobre a política habitacional, mobilizaram recursos diversos a fim de que esse problema público relacionado à implementação do programa pudesse ser operacionalizado.

Além de nos oferecer importantes ferramentas teóricas, a literatura de inspiração pragmatista nos serviu como recurso metodológico ao chamar a atenção para a importância dos momentos de disputa ou de controvérsias como circunstâncias ricas nas quais os atores tornam visíveis os critérios e os princípios de justificação que utilizam em suas ações cotidianas (BOLTANSKI; THÉVENOT, 1999; LATOUR, 2005; PENNA, 2013). 
O conceito de controvérsia aqui empregado é compreendido como diferentes entendimentos e posições por parte dos atores acerca de um problema público que podem resultar em diferentes ações em relação a essa controvérsia. No caso específico em análise, é possível afirmar que o MCMV-E aparece como resultado de uma relação ambígua e complexa em torno da maior política habitacional do Governo Federal desde a redemocratização, o MCMV (FERREIRA, 2014; SERAFIM, 2013; ABERS; SERAFIM; TATAGIBA, 2014; JESUS, 2015). Uma relação marcada pelo conflito, mas também pela cooperação, entre atores dos movimentos de moradia e burocratas do governo federal inseridos em diferentes organizações estatais. Ao disputar com o modelo privatista de provisão habitacional predominante nas últimas décadas, ${ }^{10}$ o MCMV-E, projeto de cunho autogestionário que reivindica a participação dos cidadãos em todo o processo de gestão do empreendimento - estendendo, inclusive, para a participação em torno da gestão da cidade -, mostra-se como uma controvérsia dentro do contexto ampliado da política habitacional brasileira. Trata-se, portanto, seguindo a perspectiva pragmatista, da disputa de duas gramáticas ou racionalidades distintas: a primeira, conformada no arranjo Estado-setor da construção civil, utiliza justificativas relacionadas à gramática da eficiência e do zelo do recurso público; e a segunda, organizada sob o arranjo Estado-organizações da sociedade civil, mobiliza justificativas ancoradas na gramática do controle social e do empoderamento dos cidadãos.

Ao olharmos para ação dos diferentes atores em torno da produção do MCMV-E, temos como argumento central o de que esses atores, ao transitarem por diferentes campos ao longo de sua trajetória profissional e pessoal, adquiriram a capacidade de compreender os diferentes atores e interesses em disputa, o que lhes possibilitou o exercício do papel de mediação político-relacional entre diferentes regimes na controvérsia relativa à produção do MCMV-E. Em alguns casos, como resultado, ocorreram mudanças no programa.

${ }^{10}$ Modelo a partir do qual as empresas de construção civil têm assumido protagonismo na produção da unidade habitacional (ROLNIK, 2015; MARICATO, 2011; LAGO, 2012). 
Entendemos que a presente discussão apresenta contribuições para duas literaturas. A primeira contribuição diz respeito à ampliação do entendimento sobre "ativismo institucional” ou "ativismo burocrático" (ABERS; TATAGIBA, 2015; ABERS; 2015; CAYRES, 2015), destacando que esse ativismo em torno de compromissos sociais mais amplos pode ser construído, em alguns casos, após os atores entrarem para o corpo burocrático e não necessariamente antes. Convém recordar, por exemplo, o caso de burocratas que relataram que, ao participarem de espaços decisórios nos quais interagiram com atores da sociedade civil (GTN de destinação de terras da União ou Câmara Técnica de Habitação no âmbito do Concidades), despertaram o interesse pela temática do direito à moradia enquanto um direito social relevante, fazendo a defesa deste dentro das suas organizações.

Diferentemente de outros estudos (ABERS; TATAGIBA, 2015; ABERS, 2015; CAYRES, 2015) que buscam compreender o ativismo institucional em organizações que já possuem histórico de militância - como, por exemplo, os estudos de Abers e Tatagiba (2015) sobre a atuação de feministas no Ministério da Saúde e de Cayres (2015) sobre ativismo no âmbito da Secretaria-Geral da Presidência -, a presente pesquisa salienta o engajamento de atores em organizações que não possuem trajetória de militância em seu corpo técnico, como no caso da SPU, da CEF e do MCidades após a inflexão conservadora. Conforme discutido durante a pesquisa, somente após ingressarem via concurso público para o corpo estatal é que alguns atores, a partir da participação nesses diferentes espaços de socialização, conseguiram perceber e dar sentido às suas ações cotidianas. Pode nos servir de exemplo, ainda, o caso do burocrata que reconhecia a sua competência técnica para realização do trabalho operacional, mas não conseguia ligar essa competência à política mais ampla dentro da qual estava inserido, o que foi desenvolvido por meio da participação em algumas atividades formativas seminários, oficinas e cursos de curta duração. Essa compreensão contribui para aumentar o poder explicativo-analítico do conceito de ativismo institucional porque tenciona o momento de sua construção, que pode se dar após a entrada para as organizações uma vez que a trajetória dos indivíduos não se encerra ao ingressarem no Estado. Na nossa visão, esse entendimento também dialoga com alguns trabalhos da literatura pragmatista francesa, como o conceito de Cefaï (2009) sobre arenas públicas enquanto espaços 
de sociabilidade que propiciam aos atores o reconhecimento de posições diferentes e a construção de pactos. Em outras palavras, é afirmar que o Estado também se apresenta como um espaço de sociabilidade em torno de compromissos sociais mais amplos, possibilitando o ativismo burocrático por parte de alguns atores no exercício das suas atividades.

A segunda contribuição, ao destacarmos o papel de mediação político-relacional, especialmente dos burocratas federais envolvidos com o programa, diz respeito ao diálogo com um conjunto de estudos que tem ressaltado a importância de se compreender o papel dos burocratas de médio escalão na gestão de política pública (ABERS, 2015; CAVALCANTE; LOTTA, 2015; PIRES, 2012, 2015; LOTTA; PIRES; OLIVEIRA, 2014; GOMIDE, PIRES, 2014; LOTTA, 2015). Em particular, destaca-se o papel realizado por esses atores inseridos em políticas públicas com arranjos institucionais interorganizacionais, realçando a sua função de tradução e de negociação tanto interna às suas organizações quanto externamente, ao se relacionarem com outros órgãos. Se, dado o caráter difuso das organizações operadoras do programa, a coordenação entre essas se apresenta como um enorme desafio, a ação dos atores, muitas vezes, permitiu a minimização desse problema. No caso em tela, discutimos como, a partir de relações informais e pessoais forjadas em outros espaços e experiências, atores situados em diferentes organizações buscaram acionar essa rede de proximidade a fim de obter alguma informação que seria muito difícil de conseguir, caso seguissem o fluxo hierárquico normal. Foi o que pudemos observar, por exemplo, nos casos relativos à possível resistência da burocracia local da CEF no processo de contratação previsto na modalidade dada a ausência de competência legal para que burocratas do MCidades pudessem atuar sobre os servidores daquela organização. Muitas vezes, atores de confiança na Gerência Nacional da CEF se mobilizavam com vistas a "destravar" esses problemas. Nesse sentido, apesar das similaridades com o supracitado conjunto de estudos no que se refere ao nível de governo, entendemos que o presente capítulo contribui ao ampliar o olhar sobre essa capacidade de articulação dos atores para além das agências estatais, envolvendo, muitas vezes, atores relevantes da sociedade civil.

Dentre os vários limites, destacamos o não aprofundamento do elemento político-partidário como dimensão relevante para se compreender a 
interação entre os atores no processo de gestão do MCMV-E, a assimetria de poder das organizações dentro do arranjo de implementação da modalidade (com claro protagonismo da CEF), bem como a ausência de um olhar sobre a burocracia de nível de rua envolvida com a implementação. Desde já ressaltamos que esses pontos deverão ser levados em consideração em uma futura agenda de pesquisa sobre o tema.

Por fim, entendemos que os achados de ordem prática também oferecem uma problematização acerca da ação governamental e da gestão pública, uma vez que apresentam descrições densas de como alguns problemas públicos são compreendidos e de que maneira possíveis soluções são negociadas, realçando o caráter político e heterogêneo dos atores da burocracia envolvidos com a gestão de políticas públicas.

\section{Referências}

ABERS, Rebecca Neaera. Ativismo na burocracia? O médio escalão do programa bolsa verde. In: CAVALCANTE, Pedro; LOTTA, Gabriela (org.). Burocracia de médio escalão: perfil, trajetória e atuação. Brasília: ENAP, 2015. p. 143-176.

ABERS, Rebecca Neaera; KECK, Margareth. Practical Authority: Agency and Institutional Change in Brazilian Water Politics. New York: Oxford University Press, 2013.

ABERS, Rebecca Neaera; SERAFIM, Lizandra; TATAGIBA, Luciana. Repertórios de interação estado-sociedade em um Estado heterogêneo: a experiência na era Lula. Dados - Revista de Ciências Sociais, Rio de Janeiro, v. 57, n. 2, p. 325-357, 2014.

ABERS, Rebecca Neaera; TATAGIBA, Luciana. Institutional Activism: Mobilizing for Women's Health from Inside the Brazilian Bureaucracy. In: ROSSI, Federico M.; von BÜLOW, Marisa (org.). Social Movement Dynamics: New Perspectives on Theory and Research from Latin America. London: Ashgate, 2015, p. 73-101 
ABERS, Rebecca Neaera; VON BÜLOW, Marisa. Movimentos sociais na teoria e na prática: como estudar o ativismo através da fronteira entre Estado e sociedade? Sociologias, Porto Alegre, v. 13, n. 28, p. 52-84, set./dez. 2011. BARTHE, Yannick et al. Sociologia pragmática: guia do usuário. Sociologias, Porto Alegre, v. 18, n. 41, p. 84-129, jan./abr. 2016.

BEVIR, Mark; RHODES, Roderick A. W. Chapter 4: Interpretation. In: BEVIR, Mark; RHODES, Roderick A. W. The State as Cultural Practice. Oxford: Oxford University Press, 2010.

BRASIL. Ministério das Cidades. Déficit habitacional no Brasil. Brasília, dez. 2009.

BLIKSTAD, Karin. O agir coletivo nas interfaces da sociedade civil e do sistema político: o caso da atuação do movimento de moradia de São Paulo sobre a política pública de habitação. 2012. 166 f. Dissertação (Mestrado em Ciência Política) - Instituto de Filosofia e Ciências Humanas, Unicamp, Campinas/SP, 2012.

BOLTANSKI, Luc. El amor y la justicía como competencias: três ensayos de sociología de la acción. Buenos Aires: Amorrutú, 2000.

BOLTANSKI, Luc; THÉVENOT, Laurent. The sociology of critical capacity. European Journal of Sociology, v. 2, n. 3, p. 359-377, ago. 1999.

CALLON, Michel et al. Acting in an Uncertain World: an Essay on Technical Democracy. Massachusetts: The MIT Press Cambridge, 2009.

CAVALCANTE, Pedro; LOTTA, Gabriela. Burocracia de médio escalão: perfil, trajetória e atuação. Brasília: ENAP, 2015.

CAYRES, Domitila Costa. Ativismo institucional no coração da Secretaria-Geral da Presidência da República: a Secretaria Nacional de Articulação Social no Governo Dilma Rousseff (2011-2014). 2015. 207 f., il. Tese (Doutorado em Sociologia Política) - Centro de Filosofia e Ciências Humanas, Universidade Federal de Santa Catarina, Florianópolis, 2015. 
CEFAÏ, Daniel. Como nos mobilizamos? A contribuição de uma abordagem pragmatista para a sociologia da ação coletiva. Dilemas, Rio de Janeiro, v. 2, n. 4, p. 11-48, 2009.

COHEN, Jean L.; ARATO, Andrew. Civil Society and Political Theory. Cambridge MA: MIT Press, 1992.

DUBOIS, Vicent. Politiques au guichet, politiques du guichet. HAL archives-ouvertes, 2010. Disponível em: https://halshs.archives-ouvertes.fr/ halshs-00498010. Acesso em: 6 mar. 2019.

FARIA, Carlos Aurélio Pimenta de. Ideias, conhecimento e políticas públicas: um inventário sucinto das principais vertentes analíticas recentes. Revista Brasileira de Ciências Sociais, v. 18, n. 51, p. 21-30, fev. 2003.

FERREIRA, Regina F. C. F. Autogestão e Habitação: entre a utopia e o mercado. 2014. 2019 f., il. Tese (Doutorado em Planejamento Urbano e Regional) - Instituto de Pesquisa e Planejamento Urbano e Regional, Universidade Federal do Rio de Janeiro, Rio de Janeiro, 2014.

FISCHER, Frank. Para além do empirismo: policy inquiry na perspectiva pós-positivista. NAU Social, v. 7, n. 2, p. 163-180, mai./nov. 2016. Disponível em: http://www.periodicos.adm.ufba.br/index.php/rs/article/view/554. Acesso em: 28 Fev. 2019.

HALLETT, Tim; VENTRESCA, Marc. Inhabited institutions: Social interactions and organizational forms in Gouldner's Patterns of Industrial Bureaucracy. Theory and Society, v. 35, n. 2, p. 213-236, Apr. 2006.

JESUS, Patrícia Maria de. O programa Minha casa minha vida Entidades no município de São Paulo. 2015. 285 f., il. Tese (Doutorado em Geografia) - Faculdade de Filosofia, Letras e Ciências Humanas, Universidade de São Paulo, São Paulo, 2015.

JOHNSON, Chalmers. MITI and the Japanese miracle: the growth of industrial policy, 1925-1975. Stanford: Stanford University Press, 1982. 
LAGO, Luciana Corrêa. Autogestão da moradia na superação da periferia urbana: conflitos e avanços. Revista eletrônica E-metropolis, Rio de Janeiro, n. 5, p. 6-12, jun. 2011.

LANGE, Matthew; REUSCHEMEYER, Dietrich (org.). States and development: historical antecedents of stagnation and advance. New York: Palgrave Macmillan, 2005.

LASCOUMES, Pierre; LE GALÈS, Patrick. A ação pública abordada pelos seus instrumentos. Revista Pós Ciências Sociais, v. 9, n. 18, p. 20-44, jul./dez. 2012.

LATOUR, Bruno. Reassembling the Social: an introduction to actor-network-theory. Oxford: University Press, 2005.

LOTTA, Gabriela Spanghero. Implementação de políticas públicas: o impacto dos fatores relacionais e organizacionais sobre a atuação dos burocratas de nível de rua no Programa Saúde da Família. 2010. 295 f., il. Tese (Doutorado em Ciência Política) - Faculdade de Filosofia, Letras e Ciências Humanas, Universidade de São Paulo, São Paulo, 2010.

LOTTA, Gabriela Spanguero; PIRES, Roberto; OLIVEIRA, Vanessa Elias. Burocratas de médio escalão: novos olhares sobre velhos atores da produção de políticas públicas. Revista do Serviço Público, Brasília, v. 65, n. 4, p. 463-492, out./dez. 2014.

LOTTA, Gabriela Spanguero; OLIVEIRA, Vanessa Elias. Implementando uma inovação: a burocracia de médio escalão do Programa Bolsa Família. In: CAVALCANTE, Pedro; LOTTA, Gabriela (org.). Burocracia de médio escalão: perfil, trajetória e atuação. Brasília: ENAP, 2015. p. 115-142.

MARICATO, Erminia. Metrópoles desgovernadas. Estudos Avançados, São Paulo, v. 25, n. 71, p. 7-22, jan./abr. 2011.

MARQUES, Eduardo Cesar. Redes sociais, instituições e atores políticos no governo da cidade de São Paulo. São Paulo: Annablume; Fapesp, 2003. 
MARQUES, Eduardo Cesar. Redes sociais e poder no Estado brasileiro: aprendizados a partir de políticas urbanas. Revista Brasileira de Ciências Sociais, São Paulo, v. 21, n. 60, p. 15-41, fev. 2006.

MARQUES, Eduardo Cesar. Redes sociais, segregação e pobreza. São Paulo: Editora UNESP, 2010.

MINEIRO, Edilson Henrique; RODRIGUES, Evaniza. Do Crédito Solidário ao MCMV Entidades: uma história em construção. In: LAGO, Luciana Corrêa do (org.). Autogestão habitacional no Brasil: utopias e contradições. Rio de Janeiro: Letra Capital/Observatório das Metrópoles, 2012.

MOMMSEN, Wolfgang J. The political and social theory of Max Weber: collected essays. Chicago, The University of Chicago Press, 1989.

PENNA, Camila. Conexões e controvérsias no Incra de Marabá: o Estado como um ator heterogêneo. 2013. 383 f., il. Tese (Doutorado em Sociologia) - Instituto de Ciências Sociais, Universidade de Brasília, Brasília, 2013.

PIRES, Roberto. Estilos de implementação e resultados de políticas públicas: fiscais do trabalho e o cumprimento da lei trabalhista no Brasil. Dados - Revista de Ciências Sociais, Rio de Janeiro, v. 52, n. 3, p.734-769, 2009.

PIRES, Roberto. Burocracias, gerentes e suas "histórias de implementação": narrativas do sucesso e fracasso de programas federais. In: FARIA, Carlos Aurélio Pimenta de (org.). Implementação de Políticas Públicas: teoria e prática. Belo Horizonte: Editora PUC Minas, 2012. p.182-220.

PIRES, Roberto. Por dentro do PAC: dos arranjos formais às interações e práticas dos seus operadores. In: CAVALCANTE, Pedro; LOTTA, Gabriela (org.). Burocracia de médio escalão: perfil, trajetória e atuação. Brasília: ENAP, 2015. p. 177-222.

PIRES, Roberto; GOMIDE, Alexandre de Ávila. Capacidades estatais e democracia: arranjos institucionais de políticas públicas. Brasília: Ipea, 2014. 
PIRES, Roberto; GOMIDE, Alexandre de Ávila. Governança e capacidades estatais: uma análise comparativa de programas federais. Revista de Sociologia e Política, Curitiba, v. 24, n. 58, p. 121-143, jun. 2016.

ROLNIK, Raquel. Guerra dos lugares: a colonização da terra e da moradia na era das finanças. São Paulo: Boitempo, 2015.

SERAFIM, Lizandra. Participação no governo Lula: as pautas da reforma urbana no Ministério das Cidades (2003-2010). 2013. 202 f. Tese (Doutorado em Ciência Política) - Instituto de Filosofia e Ciências Humanas, Universidade de Campinas, São Paulo, 2013.

VIANA, Rafael. Programa Minha Casa Minha Vida - Entidades: um olhar para a ação dos atores em torno das controvérsias. 2017. 147 f., il. Dissertação (Mestrado em Ciência Política) - Instituto de Ciência Política, Universidade de Brasília, Brasília, 2017.

ZITTOUN, Philippe. The political process of policymaking: a pragmatic approach to Public Policy. Houndsmills, Basingstoke, Palgrave: MacMillan, 2014. 


\section{Capítulo 8}

\section{Ativismo de servidores na educação para a democracia: os parlamentos mirins no Brasil}

Ana Marusia Pinheiro Lima

\section{Introdução}

Os parlamentos mirins são programas oferecidos por casas legislativas em municípios espalhados pelo território nacional em que crianças e adolescentes atuam como políticos. A iniciativa pode partir dos parlamentares; os servidores que coordenam os programas, contudo, têm papel imprescindível para o desenho institucional, ou seja, a execução e o desenvolvimento do parlamento mirim. Ao ter contato com informações e/ou estruturas de poder, os coordenadores veem como fundamentais o conhecimento e a participação de todos os cidadãos nessas estruturas, começando pelas crianças, para promover ou manter a transformação social.

À primeira vista, a participação infantil na casa legislativa parece irrecusável, diante de vantagens como o aumento da visibilidade e da imagem 
positiva do parlamento junto à sociedade. No entanto, o número de programas no Brasil que não saíram do papel ou foram descontinuados mostra que esse não é um empreendimento imune a desafios - principalmente os que envolvem embates com os vereadores. Nessa situação, os coordenadores recorrem às normas que instituem e regulamentam os parlamentos mirins e mobilizam estratégias para que os programas não sejam desativados devido a disputas de poder.

Esta pesquisa explora as circunstâncias em que servidores públicos, mais do que cumprir regras, lutam para mantê-las, chegando mesmo a enfrentar seus superiores para defender aquilo em que acreditam. Buscou-se na literatura as diversas características do ambiente burocrático e as variáveis para a inovação, a transformação e a resistência nesse espaço.

Os autores que trabalham a autonomia e o empreendedorismo de burocratas enfatizam aspectos pessoais desses indivíduos em contato com os recursos que as instituições oferecem. Mais recentemente, pesquisadores já identificam servidores públicos que atuam como ativistas. Na acepção de Abers (2019), servidores especulam oportunidades em prol de uma causa contenciosa, num esforço bidimensional de ideias e ações. Muitas vezes, lançam mão de estratégias diferentes das dos movimentos sociais, em função das especificidades do contexto do serviço público.

Outros autores têm se dedicado à atuação de servidores no parlamento, importante para a compreensão do objeto desta pesquisa. $\mathrm{O}$ ambiente legislativo tem particularidades que impactam os estafes ${ }^{1}$ de modo distinto do que seria caso estivessem no Poder Executivo. Além disso, existem atividades empreendidas pelos servidores dentro do parlamento que vão além das funções de representar, legislar e fiscalizar - como a educação para a democracia.

O estudo da ação dos servidores nos parlamentos mirins incluiu pesquisa documental e entrevistas semiestruturadas com coordenadores de cinco desses programas. As respostas revelaram um tipo de ativista i) cuja causa não tem correspondente nas bandeiras dos movimentos sociais;

1 Foram mantidos os termos utilizados pelos autores em cada literatura: burocratas, ativistas institucionais, burocráticos ou internos, estafe (do inglês “staff”). Na análise do objeto, preferiu-se "servidores". 
ii) que está numa instância municipal do Estado, de estafe enxuto, e por isso se vê extremamente próximo tanto dos detentores do mandato quanto da população; iii) que tem, como superiores simultâneos, parlamentares com posições políticas e ideológicas conflitantes.

O objeto de pesquisa também evidenciou fatores que influenciam ideias e ações de servidores ativistas, como a hierarquia e os recursos no ambiente da administração pública. Tais fatores já estavam presentes na literatura, mas de modo diluído, transversal. Com base neles, este trabalho estruturou-se em torno de três chaves analíticas: $i$ ) a relação entre servidores e seus superiores (em especial os detentores de mandato); ii) as estratégias que os servidores empregam para lidar com esses superiores e angariar recursos de poder; e iii) os efeitos dessas estratégias.

A análise do campo ainda trouxe informações que podem contribuir para o debate sobre ativismo na burocracia estatal. No tocante às ideias, as causas dos parlamentos mirins ajudaram no esboço de uma tipologia das diferentes contendas ativistas: são as resistências e oposições por parte de pessoas e grupos na sociedade, de superiores hierárquicos e de outros órgãos no Estado e, de modo mais abstrato, de complexos sistemas de poder. No que se refere às ações, os coordenadores mirins apresentaram um comportamento similar interessante: diante de desafios, lideraram diversas frentes, articulando-as em torno de si e conseguindo, assim, perenizar esse esforço, mesmo sem sua presença.

Alinhavando-se tais achados com todo o respaldo teórico, chega-se ao argumento central deste trabalho: no caso de uma contenda hierárquica, especialmente quando se trata de um superior imediato ou muito próximo, o servidor ativista empreende duas estratégias para obtenção de recursos na defesa de sua causa: i) a institucionalização das práticas; e ii) a construção de redes dentro e fora do Estado. Na combinação de ambas, um aspecto se destaca: a despersonalização deste servidor, paradoxalmente ao seu papel de liderança.

\section{Um ativismo inesperado: considerações metodológicas}

Inicialmente, esta pesquisa tinha por objetivo observar os resultados das práticas de educação para a democracia na relação entre cidadãos e instituições 
representativas, no caso a participação política infantojuvenil nos parlamentos. À medida que avançava, no entanto, acabou por desvelar a importância do papel dos servidores nessas práticas, exigindo um novo olhar teórico e metodológico.

O trabalho compreendeu três fases: $i$ ) o mapeamento inédito de parlamentos mirins no país e a descrição dos desenhos institucionais mais comuns, incluindo a coleta de informações via internet e telefone, pesquisa documental e análise de conteúdo; ii) a realização de entrevistas semiestruturadas com coordenadores de programas; e iii) a construção dos alicerces que iriam estruturar a revisão literária e a apresentação dos dados empíricos.

Restringiu-se o mapeamento às casas legislativas com programas voltados a estudantes do ensino fundamental, com o suporte da ferramenta de busca Google. Foram encontradas alusões a 295 municípios com programas dessa natureza. Até abril de 2015, 172 câmaras municipais foram contatadas por e-mail e/ou telefone, ${ }^{2}$ com a confirmação de 88 parlamentos mirins vigentes, com a seguinte distribuição por estado:

Tabela 1: Câmaras Mirins por estado

\begin{tabular}{|l|c|}
\hline \multicolumn{1}{|c|}{ Estado } & Câmaras Mirins \\
\hline Santa Catarina & 24 \\
\hline Rio Grande do Sul & 20 \\
\hline São Paulo & 19 \\
\hline Paraná & 9 \\
\hline Minas Gerais & 5 \\
\hline Paraíba & 3 \\
\hline Rio de Janeiro & 3 \\
\hline Mato Grosso & 2 \\
\hline Espírito Santo & 1 \\
\hline Goiás & 1 \\
\hline Sergipe & 1 \\
\hline \multicolumn{1}{|c|}{ Total } & 88 \\
\hline
\end{tabular}

2 A autora agradece a Jurema Baesse, Aline Lima e Maria Eduarda Cardim pelo auxílio no levantamento e na confirmação. 
Quase metade das câmaras municipais contatadas não confirmou a vigência do parlamento mirim, a despeito de alusões presentes na web, conforme o gráfico 1, a seguir:

Gráfico 1: Contatos com Câmaras Municipais

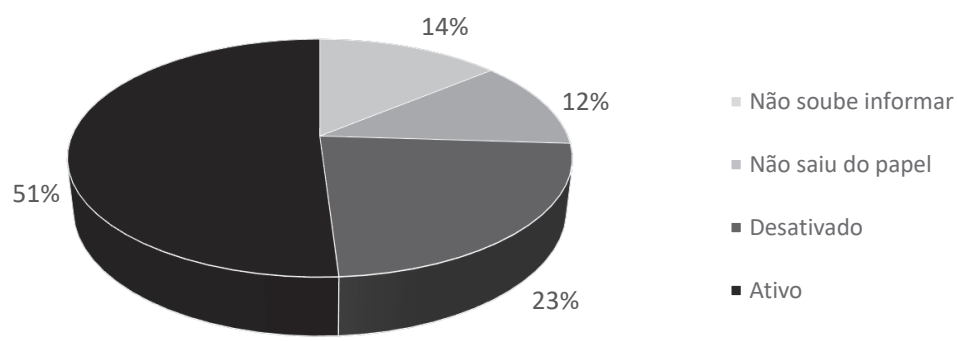

A quantidade de programas não confirmados ou descontinuados mostra que o parlamento mirim não é um empreendimento trivial. Desconstroem-se, assim, possíveis noções preliminares de que a participação política infantil seria sempre benéfica ou desejável. No contato por telefone, os motivos alegados para a interrupção do programa foram a falta de interesse (das crianças, das escolas, dos vereadores) e de verba.

Com esses dados, detectou-se a necessidade de aprofundar a discussão. Assim, foram selecionados cinco programas de parlamento mirim e realizadas entrevistas, por telefone, com o coordenador de cada um deles entre abril e junho de 2015, sendo dois servidores efetivos do quadro, um servidor efetivo cedido pela secretaria de educação e dois comissionados. ${ }^{3}$ A seleção abrangeu quatro câmaras municipais que tinham, em 2015, programas com mais de cinco anos de vigência (o que denota sua institucionalização, englobando no mínimo duas legislaturas), cujo mandato infantil se estendesse ao longo do ano letivo, e que se empenhasse na divulgação de resultados satisfatórios. E ainda uma câmara municipal que tivesse desativado o programa.

3 Por se tratar de dados sensíveis, de pessoas que ainda trabalham nas instituições, este texto não divulgará o nome dos municípios pesquisados. Os servidores serão mantidos em anonimato e tratados no masculino. Suas falas também não serão agrupadas em torno de um número nem de uma data. 
A seleção não foi aleatória. Incluiu cidades de três regiões do país: uma capital, duas cidades no estado com maior número de programas (Santa Catarina) e dois programas entre os mais antigos - um ativo e outro desativado. A ideia foi trabalhar com municípios e instituições de realidades distintas (número de habitantes, PIB e renda per capita; recursos naturais, econômicos, políticos, sociais e culturais; região do país), a fim de identificar similaridades úteis para o entendimento da ação dos servidores como um dos aspectos que contribuíssem para a continuidade do parlamento mirim.

Em março de 2018, três novas entrevistas foram realizadas com as mesmas pessoas, que já não estavam mais na coordenação dos parlamentos mirins (ainda ativos). Não foram encontrados os coordenadores do programa desativado e de um dos ativos, que havia se aposentado. Essa nova rodada de entrevistas permitiu observar os parlamentos mirins e as ações dos servidores numa visão mais processual.

As respostas dos servidores revelaram um ativismo inesperado e suscitaram um terceiro esforço de pesquisa: a busca por referências, na literatura, de autores dedicados ao papel de burocratas nas mudanças sociais.

\section{Empreendedorismo e ativismo na burocracia}

De modo geral, as pessoas que trabalham na administração pública são denominadas "burocratas”. A definição de burocracia, na literatura, tem a inegável influência da obra de Weber (1982, 1997, 2012). Ele a descreve como um corpo “neutro” politicamente (WEBER, 1982), uma forma racional, objetiva, impessoal e hierárquica de organização administrativa dentro do Estado.

Weber (2012) considera a burocracia uma forma de dominação, uma das "estruturas sociais mais difíceis de destruir” (WEBER, 1982, p. 264-265), em razão da união entre racionalidade e beneficência social (WEBER, 1997). Por isso, a ação do burocrata deve ser limitada pelas normas e pelos superiores, que deteriam os "meios de produção" do Estado, numa concentração de recursos materiais de administração análoga à de grandes empresas capitalistas (WEBER, 2012).

Os recursos "simbólicos" de autoridade legitimada também estariam fora das mãos dos burocratas: 
[...] a cadeia de responsabilização é bem clara: o burocrata responde ao político que, por sua vez, responde à sociedade. Assim, tradicionalmente, o modelo weberiano da função pública a reparte em dois grandes protagonistas: a classe política, que possui representatividade democrática para tomada de decisão e o serviço público profissional, regido pela meritocracia. (LOTTA, 2010, p. 34).

No entanto, diversas ramificações teóricas objetam a dicotomia entre decisão e ação, reconhecendo o servidor público como um ator que pode exercer autonomia, interferir no fazer político e, até mesmo, opor-se a seus superiores. Há pesquisadores que discorrem sobre ações individuais de empreendedorismo institucional na burocracia e, mais recentemente, identificam até mesmo formas de ativismo no corpo de servidores.

Estudos sobre ativistas burocráticos brasileiros contribuíram para ampliar o próprio conceito de ativismo. De acordo com Abers (2019), o ativismo consiste na busca proativa de oportunidades para defender causas contenciosas. Essa é a definição utilizada neste trabalho. Para a mesma autora, o ativismo é "um tipo de ação que visa promover projetos políticos ou sociais percebidos pelo ator como de natureza pública ou coletiva” (ABERS, 2015, p. 148). Assim, a militância não é mais exclusiva dos movimentos sociais, nem necessariamente a tentativa de impor mudanças; ela pode ocorrer sob a forma de ocupação de um cargo na administração pública ou, ainda, de apoio à continuidade de um determinado programa governamental.

Nesse universo, é possível divisar servidores públicos, incluídos os concursados, que encampam causas mesmo quando isso significa contestar as prioridades dos superiores, desconfigurando, "surpreendentemente”, o senso comum de que burocratas profissionais seriam meros seguidores de regras, tecnocratas políticos ou individualistas egoístas (ABERS, 2019).

De que maneira burocratas exercem autonomia, em nome de transformações dentro e fora do Estado, mesmo diante das pesadas restrições a que estão sujeitos? Carpenter (2001) observa que eles possuem capacidades organizacionais para resolver problemas. São empreendedores burocráticos com habilidade para inovar. Têm, ainda, a aptidão de fomentar nos outros atores a cooperação em ações coletivas, conceituada por Fligstein (2001) 
como "habilidade social” (social skill). Já Pettinicchio (2012) mostra que os ativistas estatais encampam causas em função de histórias de vida, ambições de carreira ou razões ideológicas. Essas características de cunho pessoal são causa (e efeito) da obtenção de legitimidade para agir, pautada em sólida reputação dentro e fora da instituição.

$\mathrm{Na}$ presente pesquisa, o movimento de idas e vindas entre teoria e campo identificou outros dois fatores que se somam aos aspectos individuais dos burocratas na busca pela transformação social: a hierarquia e os recursos disponíveis em decorrência de sua posição na administração pública. Esses fatores influenciam as ideias e ações que, por sua vez, produzem efeitos dentro e fora das instituições. Saliente-se que ideias e ações são dimensões inseparáveis do ativismo (ABERS, 2019), como aliás também o são hierarquia e recursos: a divisão entre eles é uma opção analítica.

\subsection{Relações hierárquicas e seu impacto na atuação transformadora dos burocratas}

\subsubsection{Hierarquia e ideias}

Ao entrar em um órgão do Estado, o burocrata se insere em um processo de socialização. Os líderes iniciam gradualmente os novos funcionários em um determinado padrão de agência e na cultura de identificação com ela, convencendo-os de que essa é a condição para que se desenvolvam as trilhas de carreira e o reconhecimento de status na burocracia. O padrão de agência pode ser vigente ou novo: os chefes podem mantê-lo ou alterá-lo, utilizando a cultura burocrática para protegê-lo quando já não estiverem em seus cargos (CARPENTER, 2001).

Distinguem-se, portanto, dois campos na instituição: um, dominante, que intenta reproduzir sua posição; e outro, desafiador, que busca oportunidades em crises (FLIGSTEIN, 2001). As relações entre burocratas e seus superiores mudam a depender dos campos em que se situam e com o que se identificam. Paradoxalmente, a autonomia burocrática, em sua forma mais poderosa, prevalece quando detentores de mandato e burocratas estão politicamente alinhados (CARPENTER, 2001). O servidor, assim, se vê no desafio de equilibrar o apoio político que recebe com sua própria independência (HYSING, 2014). 
Isso também vale para o ativismo. A hierarquia pode fomentar ou entravar a presença de ativistas no Estado. Em alguns casos, o ativismo é praticado pelos próprios chefes, sejam políticos ou membros da administração. Em outros, a própria divergência com o superior pode se tornar uma contenda ativista para o burocrata.

Ressalte-se que, ao lidar com múltiplas questões, o burocrata não responde a um único político, nem a um único objetivo. Está submetido simultaneamente a diferentes camadas de hierarquia, às vezes com posições díspares, num Estado heterogêneo (MEIER; O’TOOLE, 2006).

\subsubsection{Hierarquia e ações}

Seja para reproduzir ou contestar um sistema de poder e privilégio, os servidores com habilidade social buscam obter a cooperação dos outros atores, aliados ou opositores, dentro e fora do campo (FLIGSTEIN, 2001).

Quando o chefe é ativista, sua atuação inclui a blindagem dos subordinados, a alocação (ou não) de recursos em decorrência de posições ideológicas e o recrutamento de outros ativistas (OLSSON, 2009; PETTINICCHIO, 2012; ABERS; TATAGIBA, 2015), transformando o próprio Estado (BANASZAK, 2010; NIESZ; KRISHNAMURTHY, 2013).

Niesz e Krishnamurthy (2013) descrevem a ação combinada de um administrador ativista em relações horizontais e em decisões “de cima para baixo”. No primeiro caso, o administrador se colocava no mesmo nível dos subordinados, punha a "mão na massa” e organizava fóruns em que todos tinham direito à voz. No segundo, usava de sua posição hierárquica para consolidar um programa - que persistia mesmo após sua aposentadoria. No sentido “de baixo para cima”, de modo análogo, Hysing (2014) localizou ora ativistas que usavam de informalidade e familiaridade com seus superiores, ora os que buscavam influenciá-los de modo técnico, profissional.

E no caso de um chefe opositor? Uma vez que os burocratas valorizam sua autonomia, eles preferem agir de forma calculada para preservá-la, evitando estratégias que desafiem os eleitos (CARPENTER, 2001). A escolha por meios não ostensivos distingue o ativista interno do ativista social. Este último tem um estilo ideológico voltado para o conflito, de forma incompatível com o papel dos servidores públicos, ao passo que o ativista 
interno raramente busca alcançar seus objetivos atacando ou obstruindo abertamente as decisões políticas (OLSSON; HYSING, 2012). Ele lida com as disputas em níveis que não são alcançados pelo topo da hierarquia, por meio de ações "fora do radar" (BANASZAK, 2010) num "ativismo em segredo” (OLSSON; HYSING, 2012).

\subsection{Recursos e seu impacto na atuação transformadora dos burocratas}

Ainda que possam exercer influência, dificilmente os servidores têm a palavra final na tomada de decisões (OLSSON; HYSING, 2012). Por isso, eles se empenham em desenvolver ou angariar recursos de poder. Dois tipos (não excludentes) sobressaem: os fatores intrínsecos ao serviço público e as redes dentro e fora do Estado.

\subsubsection{Recursos e ideias}

Os ativistas potencializam a expertise, tipicamente associada ao servidor público (HYSING, 2014), somando experiência, competência e interesse em determinados temas. Tal interesse pode se guiar por diversas razões. Segundo Banaszak (2010), atores estatais preocupam-se com a manutenção do Estado como um todo, da burocracia como instituição e também do órgão no qual trabalham, bem como com o atendimento a demandas externas de seus clientes.

O burocrata recebe forte influência da cultura organizacional, que pode até suplantar sua identificação com partidos, localidades ou profissões (CARPENTER, 2001). Ao mesmo tempo, a participação em redes externas múltiplas (como movimentos sociais, associações profissionais, ONGs), no decorrer de sua trajetória de vida, pode trazer ao ativista dentro do Estado o compartilhamento de objetivos (BANASZAK, 2010; OLSSON, 2009; SANTORO; MCGUIRE, 1997) e o suporte (inclusive financeiro) (HYSING, 2014), mas pode trazer, também, cobranças que outros burocratas não enfrentam (ABERS; TATAGIBA, 2015). Esses interesses se transformam à medida que ele se ocupa com determinados trabalhos, podendo chegar até à intenção de mudanças mais revolucionárias (BANASZAK, 2010). 


\subsubsection{Recursos e ações}

O burocrata estatal tem acesso privilegiado aos meios institucionais sendo a informação um dos mais valiosos - e aos processos de elaboração e implementação de decisões (SANTORO; MCGUIRE, 1997; HYSING, 2014). Como empreendedor e ativista, ele procura influenciar as elites usando as próprias regras da instituição (PETTINICCHIO, 2012), ou fazer novas regras com base em padrões de interação (FLIGSTEIN, 2001).

Na proximidade com o poder, os ativistas internos identificam o vácuo dos eleitos para atuar (OLSSON, 2009; HYSING; OLSSON, 2012). Mostram evidências "técnicas”, supostamente neutras. O trabalho é feito passo a passo (NIESZ; KRISHNAMURTHY, 2013), às vezes, à espera do instante mais favorável, respaldado pela estabilidade e pelo monitoramento contínuo de processos (HYSING, 2014) que os ajudam a sobreviver durante administrações hostis (BANASZAK, 2010). Os ativistas elaboram treinamentos, protocolos, planos, manuais, que possam documentar e perenizar os esforços (ABERS; TATAGIBA, 2015; ABERS, 2015; NIESZ; KRISHNAMURTHY, 2013).

As redes também são recursos de fundamental importância para os burocratas ativistas. Seja em redes existentes, às quais já tinham acesso, seja naquelas que eles próprios tecem, sua posição no Estado transforma substancialmente a forma com que se vinculam a elas.

Segundo Carpenter (2001), os empreendedores burocráticos precisam de legitimidade e reputação organizacional. Por isso, criam e conciliam alianças múltiplas e diversas em torno das inovações e políticas que defendem, de modo que seja difícil opor resistências a elas. Coalizões amplas tornam a agência menos dependente de políticos e de quaisquer outros parceiros, permitindo ao burocrata alterar agendas e preferências.

Dentro do Estado, ativistas buscam localizar atores com afinidades (BANASZAK, 2010) e integrar-se a outros departamentos e órgãos (HYSING, 2014). Nas fronteiras com a sociedade, criam conexões com a academia, a mídia e os formadores de opinião (OLSSON, 2009; HYSING; OLSSON, 2012); abrem fóruns de participação (BANASZAK, 2010); difundem conhecimentos para quebra de resistências, ceticismos e preconceitos de políticos, outros burocratas e cidadãos (ZWARICH, 2009); 
mobilizam ativistas outsiders para que façam oposição ostensiva, como protestos (HYSING; OLSSON, 2012; PETTINICCHIO, 2012).

Atores com habilidade social configuram parâmetros de discussão e disseminam valores que são vistos como compartilhados pelos demais atores e não como interesses individuais do líder (FLIGSTEIN, 2001). Assim, como ativistas, conseguem estabelecer diálogo com implementadores da linha de frente e cidadãos, fazendo deles multiplicadores e coautores dos resultados (NIESZ; KRISHNAMURTHY, 2013).

\subsubsection{Efeitos de ideias e ações dos burocratas}

Para Fligstein (2001), desafiantes são bem-sucedidos numa crise (oportunidade política) quando são capazes de mobilizar recursos e produzir uma identidade política que una os grupos. A literatura sobre ativismo em instituições estatais traz alguns efeitos dessa atuação: a formação de uma agenda e a criação e implantação de políticas (HYSING, 2014; OLSSON, 2009); a aprovação de legislação que transforma demandas sociais em direitos; a criação de órgãos no governo (PETTINICCHIO, 2012); a permeabilização de estruturas políticas e a criação de novos espaços de participação ou mesmo de movimentos, com a complementariedade de resultados obtidos pelos ativistas outsiders (BANASZAK, 2010; SANTORO; MCGUIRE, 1997).

Existe também um trabalho educativo de mudança de mentalidades (ZWARICH, 2009). Em alguns casos, a mobilização de redes dentro e fora da administração, por parte dos ativistas burocráticos, transforma o próprio sistema (NIESZ; KRISHNAMURTHY, 2013).

O rol de ações enumeradas na literatura confirma o que Fligstein (2001) observou: indivíduos com habilidade social costumam abrir várias frentes ao mesmo tempo para que sua ação se sustente perante o grupo, caso alguma delas falhe. Ainda assim, o autor reconhece que eles nem sempre atingem seus objetivos. Ou, mesmo que os alcancem, precisam se dedicar à sua manutenção (reprodução).

A bibliografia aqui referida se volta para a burocracia do Poder Executivo. Como se dá o trabalho de servidores numa casa legislativa e a que lógicas eles estão submetidos em relação a hierarquias e recursos? É o que será visto a seguir, já como introdução ao objeto de pesquisa, que são os parlamentos mirins. 


\section{Estafes no legislativo}

A ênfase dos autores que focam os estafes no Poder Legislativo recai no trabalho das comissões e na elaboração das leis, compreensível pelo fato de refletirem a função mais visível do parlamento. O estudo de programas institucionais notadamente de cunho educativo enriquece essa ótica ao revelar, para além do processo legislativo, suscetibilidades em relação à hierarquia e aos recursos, ao mesmo tempo em que apresenta uma interessante instância de ativismo no Estado.

\subsection{Relações hierárquicas e seu impacto na atuação transformadora do estafe}

O parlamento caracteriza-se pelo pluralismo, que cria desafios diferenciados para seus servidores. No Executivo, é possível divisar um eixo compartilhado na condução política e administrativa e assim saber o que esperar de quem está no comando. O mesmo não ocorre no Legislativo, com sua ampla e característica presença de políticos com posições divergentes. Além disso, ainda que tenham sido todos eleitos, os parlamentares têm "pesos" distintos, a depender do cargo de direção que ocupam na casa ou do partido a que pertencem (minoria ou maioria). O estafe precisa lidar com essa diversidade. Há, ainda, as transformações de gestão em intervalos menores que no Executivo, causadas pelas mudanças de Mesa Diretora, ${ }^{4}$ que podem ser extremamente bruscas e substanciais nas atividades legislativas e mais ainda nas institucionais.

\subsubsection{Hierarquia e ideias}

Hammond $(1984,1996)$ enumera estudos sobre os padrões de atividade dos estafes; seus recursos e limites; suas especificidades; sua influência e o efeito de sua ação nas instituições. Um denominador comum é o forte

4 A Mesa dirige os trabalhos legislativos e administrativos da casa. No Brasil, é eleita pelos parlamentares a cada dois anos. 
impacto da relação entre profissionais e parlamentares na atuação de ambos. Parlamentares dependem da expertise e capacidade analítica dos profissionais devido à complexidade do processo legislativo (especialmente as leis orçamentárias) e da função fiscalizatória, somada à relevância pública dos diversos temas em pauta. Assim, o estafe amplia sua autonomia, mas ainda depende do poder de decisão dos parlamentares.

Quando o relacionamento entre profissionais e parlamentares se caracteriza por mútua lealdade, confiança, segurança e, geralmente, estabilidade (PATTERSON, 1970), os membros do estafe recebem um poder derivativo, delegado, como um transbordamento da influência do parlamentar (DEGREGORIO apud ROSENTHAL; BELL, 2002) que os posiciona como líderes ou representantes não eleitos (HAMMOND, 1996).

Para além do relacionamento individual entre o membro do estafe e o parlamentar, há a dinâmica dos colegiados nas comissões legislativas. Quanto maior for o caráter técnico e não partidário da comissão, maior será o apoio ao desempenho do estafe (PATTERSON, 1970). Os objetivos e as orientações do presidente e da maioria da comissão são os fatores mais importantes na orientação e atividade dos profissionais (PRICE, 1971).

Em relação aos trabalhos institucionais, Cosson (2008) realiza uma ampla pesquisa sobre as escolas do Legislativo. Ele explica que as trocas de mesa podem trazer controvérsias sobre o papel do parlamento e de seus programas nas perspectivas da direção e do corpo técnico. Ao mesmo tempo, os servidores se deparam com a tendência de se querer partir do zero a cada nova administração como forma de extinguir o que outros parlamentares e partidos realizaram anteriormente e que ficou a eles vinculado, numa relação de concorrência.

\subsubsection{Hierarquia e ações}

Os servidores no Legislativo exercem um poder invisível (ROSENTHAL; BELL, 2002) em ambas as circunstâncias de alinhamento ou de discordância em relação a seus superiores. Tal invisibilidade também é estratégica. Patterson (1970) reporta uma forte norma tácita, comentada por membros do estafe entrevistados, de não ultrapassar a linha que os separa dos parlamentares: be on tap, and not on top (esteja à mão, não no topo), not try to 
run the show (não tente conduzir o show). O autor complementa: o estafe trabalha do modo que se espera dele, ou seja, de forma objetiva, contida e não doutrinária, abafando suas preferências políticas individuais. Quanto mais contido, maior é sua chance de ser influente.

Para Price (1971), o comportamento dos profissionais varia em função do espaço oferecido pela comissão legislativa: ora usariam sua expertise para análise de informações e apresentação de alternativas de modo neutro e reativo, ora se empenhariam na contínua busca de lacunas e oportunidades políticas para implementar suas próprias preferências, atuando, nas palavras do autor, como ativistas partidários.

No que tange aos programas institucionais, Cosson (2008) mostra que, para atingir seus objetivos em contextos de sucessivas mudanças, os servidores apostam na estabilidade institucional. Assim, investem em planejamento e ações de longo prazo, para a consolidação de um espaço que pertença ao parlamento e não seja meramente o resultado de uma ação dos parlamentares.

\subsection{Recursos e seu impacto na atuação transformadora do estafe}

\subsubsection{Recursos e ideias}

Ao trabalhar com a elaboração das leis, o estafe do Legislativo se move pela inovação, pela oportunidade de dar início a políticas públicas. Seus burocratas não têm obrigação com accountability nem sofrem com as pressões eleitorais (PATTERSON, 1970), mas mantêm um grau de responsabilidade democrática quando refletem características de raça, sexo, etnia e classe social dos públicos para os quais as leis são feitas (ROSENTHAL; BELL, 2002).

Ao ter contato com informações e/ou estruturas de poder, alguns servidores se sentem propensos a fomentar o conhecimento e a participação de todos os cidadãos nessas estruturas para promover a transformação social. Segundo Cosson (2008), os programas educativos no parlamento inicialmente almejam uma interação maior entre parlamentares e sociedade e a melhoria da imagem da casa. Contudo, acabam contribuindo para a promoção e o fortalecimento da democracia por meio da educação cidadã, na formação e a qualificação de lideranças comunitárias e políticas. 
Vislumbra-se, assim, um novo papel do parlamento, para além das funções de representar, legislar e fiscalizar: trata-se da função pedagógica, na construção de uma cultura democrática, enriquecida pelo encontro entre os diferentes. O “pluralismo” intrínseco ao Poder Legislativo teria vantagens didáticas (CASTRO et al., 2012).

\subsubsection{Recursos e ações}

De acordo com Patterson (1970), os profissionais mais respeitados e os de melhor desempenho são os não partidários, que trabalham para membros de todos os partidos. Eles buscam a integração com membros de outros setores dentro e fora do parlamento (PATTERSON, 1970); demonstram criatividade na elaboração e comunicação de planos e soluções (PRICE, 1971); oferecem assistência aos parlamentares em sua função representativa - e também lhes dão mais trabalho -, trazendo ideias de grupos que não têm voz, visando legislações mais inclusivas (HAMMOND, 1984).

Já nos programas institucionais educativos, os servidores se dedicam a atividades de capacitação do corpo técnico, de aproximação com a sociedade e de produção de conhecimento sobre o Legislativo (COSSON, 2008).

\subsubsection{Efeitos de ideias e ações do estafe}

Mesmo com restrições, o estafe pode orientar o processo legislativo e imprimir suas próprias preferências à legislação criada. Os resultados são mais efetivos quando o profissional se identifica com interesses e ambições de seu superior eleito (especialmente se ele está em posição de destaque no parlamento), e a eles agrega a capacidade de oferecer informações e soluções (PRICE, 1971).

O trabalho institucional, por sua vez, precisa ser constantemente justificado - mesmo quando há sintonia com os dirigentes -, porque não faz parte das atividades-fim do parlamento (COSSON, 2008).

Após essa breve imersão na literatura, passa-se à descrição do ambiente de estudo e à análise do ativismo de servidores nos parlamentos mirins. 


\section{Parlamentos mirins no Brasil}

\subsection{Desenhos institucionais}

De acordo com o levantamento prévio dos 295 parlamentos mirins no Brasil, os programas são instituídos por lei municipal, resolução ou decreto-legislativo. A iniciativa parte dos vereadores. A complementação às normas pode ser feita por regimento interno, edital ou apenas um regulamento de aprimoramento contínuo. A maioria dos programas é coordenada por servidores, mas há os coordenados diretamente por vereadores.

Entre os objetivos do parlamento mirim estão: i) o entendimento dos aspectos políticos da sociedade brasileira e a vivência do processo democrático (mediante simulação do trabalho parlamentar); ii) a interação entre a câmara municipal e a escola, por meio de informações sobre projetos, leis e atividades gerais da casa; iii) a sensibilização de professores, funcionários e pais para o exercício da cidadania responsável e a atuação na política municipal, construindo uma sociedade solidária, moderna e plural desde a infância; iv) a criação, junto à comunidade, de espaços para a contínua aprendizagem dos jovens; v) a motivação e a identificação de novas lideranças estudantis; e vi) a discussão e reflexão sobre os problemas que mais afetam a população, com incentivo à elaboração de soluções para a cidade.

A cada edição, o processo do parlamento mirim tem início com a escolha das escolas participantes. A definição pode ser por indicação da Secretaria de Educação, por solicitação, sorteio ou rodízio. A seleção dos vereadores mirins pode ocorrer via eleição na própria escola, processo seletivo (prova) ou concurso de redação.

Os mandatos podem ser de apenas um dia ou se estenderem por todo o ano letivo. Na maioria dos casos, a reeleição não é permitida. O número de vereadores mirins, em geral, corresponde ao número de vereadores do município. Há programas que dividem os estudantes em partidos temáticos (por exemplo, Educação ou Meio Ambiente), ou estabelecem as próprias escolas como partidos. Nos casos pesquisados, é veementemente proibida qualquer associação com partidos políticos reais, seja durante a fase de campanha ou ao longo de todo o mandato das crianças. 
De acordo com os entrevistados, os maiores ganhos institucionais do parlamento mirim são a mídia positiva, o aumento da visibilidade e a promoção da imagem da câmara municipal frente à população da cidade.

\subsection{Relações hierárquicas e seu impacto na atuação transformadora dos servidores}

\subsubsection{Hierarquia e ideias}

Os parlamentos mirins podem ser fruto da vontade dos vereadores. No entanto, as entrevistas demonstraram que o sucesso - e a sobrevivência - do programa, nos casos pesquisados, não se deveu à norma que o instituíra, nem à estrutura da instituição, nem às características do município; deveu-se ao empenho pessoal dos técnicos envolvidos na angariação de recursos e na manutenção do interesse de crianças, escolas e vereadores.

Quando servidores são nomeados pela Mesa Diretora para coordenar o parlamento mirim, eles não necessariamente estão engajados com a educação para a democracia, nem com a elaboração da norma que deu origem ao programa. A partir do momento em que se envolvem, assumem os objetivos do programa e a eles agregam seus próprios valores. Por sua vez, seus valores também são afetados com a experiência.

Com o tempo, o entusiasmo inicial dos parlamentares, em especial dos que criaram o programa, pode dar lugar a vinculações, concorrências, questionamentos e controvérsias. Há casos em que o programa morreu por inanição (com o corte de verbas, servidores e até espaço físico para as atividades).

\subsubsection{Vinculações e concorrências}

Nas câmaras pesquisadas, a participação dos vereadores no parlamento mirim era pouco expressiva, sendo a falta de tempo a principal alegação. Segundo os entrevistados, um dos motivos do descaso, e até da extinção do programa em determinados municípios, fora a associação do programa a um vereador ou a um partido específico, fazendo com que os demais partidos e 
vereadores, nas mesas ou legislaturas seguintes, não se interessassem pela continuidade (conforme visto por Cosson, 2008).

Outro problema é quando uma Mesa desinteressada "rifa” o cargo de coordenador, colocando alguém que não faz "jus à responsabilidade” de trabalhar a educação para a democracia com as crianças. Por isso, mesmo comissionados indicados, que geralmente gozam de alinhamento com a Mesa e não enfrentam problemas de recursos, precisam resgatar os objetivos originais do programa que, em gestões anteriores, ficaram à mercê de doutrinação política, partidária e até sindical.

\subsubsection{Questionamentos}

Os coordenadores frisam que o propósito principal do parlamento mirim é a educação para a democracia, e não a formação de futuros políticos ou a produção de leis. Por isso, apostam no resguardo da técnica, criando uma espécie de laboratório protegido. A ênfase no lado técnico em oposição ao político surge como estratégia de permanência diante das tensões. O próprio fato de convocarem crianças sublinha isso. À primeira vista, elas pareceriam "menos ameaçadoras" aos vereadores do que os cidadãos adultos, já que não votam. Mas a idade dos participantes amplia sobremaneira a responsabilidade dos educadores.

Segundo um dos entrevistados, o coordenador precisa ter uma visão diferenciada para lidar com o desenvolvimento de adolescentes. Ao participar do programa, “a evolução do vereador mirim é gigante. Ele passa a ter desenvoltura na tribuna, a argumentar os conteúdos”. Para o servidor, "se houver viés político, se o programa não tiver foco, você cria uns monstrinhos”, ou seja, pessoas com retórica forte e ética duvidosa.

Há, ainda, o medo de que as crianças causem constrangimento político. Num dos casos, comentou-se que as crianças que acompanhavam as sessões plenárias reais já identificavam toda a sorte de comportamentos repreensíveis, em desconformidade com que estavam aprendendo nas palestras, oficinas e simulações do programa. 
Quando se está numa casa essencialmente política, esse problema é notório, ${ }^{5}$ como no estudo de Macedo et al. (2013) sobre a Câmara Mirim de Pouso Alegre (MG):

Na região, várias cidades criaram suas Câmaras Mirins, no entanto, somente a de Pouso Alegre (MG) permanece com atividades e se atualiza constantemente. Os motivos da não continuidade destas câmaras mirins da região, conforme entrevistas na fase exploratória, se deu praticamente por dois motivos: falta de interesse político, considerando que os políticos têm pouco interesse em dar continuidade em projetos iniciados por gestões anteriores e por receios dos possíveis questionamentos que estas Câmaras Mirins poderiam fazer na Câmara de Vereadores. (MACEDO et al., 2013, p. 3).

\subsubsection{Controvérsias}

Para além dos embates partidários, há as disputas por recursos da administração da câmara. Diferentemente de órgãos do Executivo que têm aporte financeiro próprio ou mesmo rubricas constitucionais, as câmaras municipais têm orçamento limitado, que não prevê implementação de políticas públicas como atividades educativas. Surgem as controvérsias sobre a necessidade do parlamento mirim e até do letramento político dos cidadãos.

Um dos entrevistados contou que, numa legislatura recente, a Mesa não fazia interferência no programa, nem pretendia fazer exploração política do sucesso do parlamento mirim. Era pior: "não tinha interesse por nada” e o programa era visto como um peso. "Houve sufocamento das condições de trabalho”. Atividades deixaram de ser realizadas e até o espaço se tornou uma dificuldade, porque as reuniões não puderam ser feitas no plenário.

E prossegue: "com uma falácia de economia, cortou geral sem preocupação com consequências. Atingiu outras áreas da casa também, e não apenas

5 Um exemplo é a censura pública sofrida por uma vereadora mirim em Juara-MT, pela presidente da câmara municipal e idealizadora do programa na instituição, por ter criticado a prefeitura (ver VEREADORA..., 2011). O parlamento mirim de Juara foi descontinuado. 
o programa”. Ostentavam "austeridade” na mídia, mas havia "suspeitas de contratos escusos, reformas desnecessárias e dispendiosas”, além de autoritarismo no trato, no clima organizacional. Para ele, não era uma divergência ideológica contra o programa em si. "É um nível mais baixo; é pior do que ser ideológico, porque você não consegue nem discutir para convencer”.

\subsubsection{Hierarquia e ações}

O que fazem os servidores quando aparecem conflitos de ideias? O enfrentamento com os parlamentares, ainda que constante, não se dá ostensivamente. Para lidar com contendas, uma das estratégias dos servidores nos parlamentos mirins selecionados foi a institucionalização.

A primeira preocupação dos coordenadores entrevistados é o cumprimento de normativos e o estabelecimento de práticas que assegurem a condução dos trabalhos no parlamento mirim - a estabilização, no dizer de Fligstein (2001). Eles focam no caráter institucional do programa, de forma a desvinculá-lo completamente de questões político-partidárias da câmara municipal e dos detentores de mandato. Esse cuidado visa, antes de tudo, manter a autonomia para que os objetivos didáticos da atividade possam ser alcançados.

Busca-se evitar a apropriação do programa para fins marqueteiros e eleitorais de certos parlamentares. Há uma tensão permanente no parlamento mirim, que é uma vitrine positiva da câmara, mas não pode chegar ao ponto de se tornar objeto de uso promocional dos vereadores. Isso reitera o entendimento de Cosson (2008) sobre a ameaça constante da transformação do programa educativo numa máquina partidária que, quanto mais eficiente, mais danosa será para seu futuro como instituição de ensino.

Nas palavras de um entrevistado, “o projeto deverá ser da instituição Poder Legislativo, não devendo ser apadrinhado por um ou outro vereador. Ele deve ter o apoio de todos para não despertar ciúmes e disputa política. Os vereadores vêm e vão, o projeto fica”. Assim, evitam-se "personalismos que limitem o apoio político ao projeto e comprometam sua perenidade”. 
Outra estratégia visa garantir a presença do maior número possível de vereadores de partidos diferentes. O Parlamento Jovem de Palmeira, ${ }^{6}$ no Paraná, prevê que cada criança participante seja “apadrinhada” por um vereador, que a acompanha por todo o mandato. Por enquanto, os resultados têm sido comemorados. ${ }^{7}$ No futuro, será possível observar se seu desenho institucional inovador teve fôlego ou se precisou ser substituído pelo formato das câmaras mirins mais experientes, citadas neste trabalho.

O “pluralismo” do parlamento, apontado por Castro et al. (2012) como diferencial pedagógico, também pode fazer com que os próprios vereadores exerçam os "pesos e contrapesos" (checks and balances) entre si. Isso, no entanto, não parte dos coordenadores dos parlamentos mirins. De acordo com um deles, "não dá para buscar apoio nos vereadores. Não dá para entrar nessa briga”.

Por último, para os entrevistados, programas longevos também têm chance maior de sobreviver. Por isso, em gestões difíceis, eles lançam mão até de recursos próprios para manter o parlamento mirim no piloto automático, na esperança de que a Mesa seguinte seja mais receptiva às ações de educação para a democracia.

\subsection{Recursos e seu impacto na atuação transformadora dos servidores}

\subsubsection{Recursos e ideias}

O empenho dos coordenadores se guia por valores pessoais ("idealismo", "vontade de contribuir com o contexto social”, no dizer deles), identificados com leis e atribuições no serviço público e com o exercício de sua função. Tais valores se retroalimentam e se transformam com os resultados obtidos. Nas palavras de um entrevistado:

${ }^{6}$ O programa não constou na seleção de entrevistas porque não havia completado cinco anos de existência na época do levantamento, o que era um requisito da análise.

7 Ver Jornal PJovem em Ação: https://drive.google.com/file/d/0B48VPn_ EXgYGXzhoNi1tZGFVdFk/view 
Nossa preocupação principal é a formação destes meninos como cidadãos; portanto, utilizamos da simulação parlamentar como instrumento didático e não como fim em si mesmo. Assim, não os submetemos a um papel sistemático e constante de "vereador", mas procuramos estimular a discussão de conteúdos e temas importantes para o exercício do diálogo e desenvolvimento de uma visão sistêmica da sociedade e dos processos coletivos.

Para os coordenadores, a informação faz diferença. Os vereadores mirins passam a ter consciência dos problemas sociais e de como o Estado funciona. A ideia é, antes de tudo, possibilitar que os estudantes aprendam seus próprios direitos para, a partir daí, poder "transformar a sociedade", "fazer um futuro melhor".

Os resultados imediatos da participação infantil, a exemplo de sugestões de leis municipais ou indicações à prefeitura, são um aspecto complementar diante de um projeto maior de mudança institucional a longo prazo. As entrevistas revelam, por exemplo, um desejo dos servidores de que a configuração da câmara possa contar com representantes mais voltados ao interesse público, eleitos por cidadãos com mais consciência. "Tivemos uma vereadora mirim que se candidatou. Nosso programa não é um curso para futuros vereadores; mas, se forem eleitos, serão bons políticos”, diz um coordenador.

Os entrevistados enfatizam que o trabalho educativo, quando bem orientado, tem um impacto muito grande no vereador mirim. Primeiro, porque, quando chegam, as crianças não fazem ideia do que seja o processo político, não entendem as instituições de poder e passam a "conhecer outros mundos”. Segundo, porque não é uma experiência pontual; os objetivos não são para o curto prazo. É um aprendizado sustentável, que traz resultados e gera comprometimento: "Quando uma pessoa se transforma, ela transforma a todos: irmãos, pais, colegas, amigos”. Isso é ainda mais intenso com estudantes de escolas públicas, "que vêm de realidades totalmente diferentes".

A intenção dos coordenadores, assim, também confirma a função pedagógica do parlamento descrita por Castro et al. (2012) e Cosson (2008). Eles entendem que a educação para a democracia, que o sistema educacional não está abarcando, deve ser iniciativa do Legislativo. 
Em um panorama maior de educação política, um dos servidores efetivos ressalta a importância da participação voluntária em atividades nas escolas de governo, que abrem a perspectiva dos servidores para além do seu papel técnico:

Nas escolas de governo, há o desenvolvimento da cidadania como papel daquela instituição. Elas atraem servidores efetivos com uma posição ideológica, um sentimento de resistência. Despertam essas pessoas que têm visão, que vão além de cumprir sua tarefa institucional, uma visão mais ampla da que têm os servidores burocráticos que batem ponto e vão para casa. Nós não ligamos de ficar depois do horário, trabalhar nos fins de semana ou nas férias. Há uma abdicação, uma ligação afetiva com a instituição.

Ele completa: “Os servidores têm consciência da necessidade de fazer com que a sociedade compreenda sua instituição, a importância do Legislativo na democracia”. E fala, ainda, sobre a estabilidade do servidor efetivo: “A estabilidade ajuda. É necessidade, não é privilégio. É o que dá a condição de manter a instituição minimamente funcionando”.

\subsubsection{Recursos e ações}

Os servidores se guiam pelas normas do parlamento mirim, interpretando-as e até propondo novos desenhos institucionais, escolhendo as melhores maneiras de atingir os objetivos do programa e também de protegê-lo. Em grande parte, suas estratégias refletem um empreendimento individual, mas preocupado em tecer redes externas que possam legitimar suas ações. Ressalte-se que é sua posição no Estado que lhes proporciona essa possibilidade, ao lhes dar acesso às redes e poder para falar em nome da instituição.

Os servidores fazem a articulação interna entre crianças participantes, corpo técnico e parlamentares. E também a externa com escolas, parceiros, mídia e outros integrantes do poder público. Assim, eles criam alianças essenciais - ainda que não determinantes - para a continuidade do programa. Estabelecem vínculos dentro e fora de seu campo, conforme amplamente documentado na literatura aqui referida. 
A primeira estratégia é a formação de parcerias, com o intuito de envolver mais pessoas, divulgar, ampliar o alcance, despertar o interesse, otimizar o trabalho, obter aliados, oferecer um panorama mais rico para o público-alvo e assim manter aceso o interesse dos vereadores mirins durante todo o processo, dando ludicidade às informações e atividades (ZWARICH, 2009). Alguns exemplos de parceiros são:

1. Prefeitura - participação em eventos; Secretaria de Educação - apoio para inscrição das escolas;

2. Judiciário - Tribunais eleitorais - apoio nas campanhas nas escolas e palestras com juízes eleitorais;

3. Órgãos públicos, universidades, ONGs, setor privado - visitas; contatos com especialistas para dar palestras gratuitas aos vereadores mirins (prática legislativa, história, finanças, saúde, segurança, oratória, liderança); atividades de responsabilidade social: doações; campanhas ambientais, antidrogas, de consciência no trânsito;

4. Equipe interna - otimização do quadro enxuto da casa;

5. Empresas privadas - fornecimento de material gráfico, uniforme, transporte e lanche;

6. Escolas (não somente as que têm vereadores mirins) - divulgação do programa; palestras; reuniões com professores; inclusão social (eleições do parlamento mirim em escolas rurais, indígenas, de ensino especial);

7. Pais - reuniões periódicas para explicação sobre o programa, comprometimento sobre frequência, ganhos na formação dos participantes;

8. Vereadores mirins - estabelecimento de vínculos, não necessariamente de amizade, mas de compromisso: "Eles sentem que você 
se preocupa, que está ali para ajudá-los a crescer”. "Eles mesmos percebem o resultado, o quanto aprenderam, o quanto passaram a compreender as coisas que veem”.

Parlamentos mirins com grande visibilidade tornam-se referência para outras casas legislativas. Esse tipo de parceria abrange contatos e intercâmbio com outras câmaras interessadas, participação em encontros estaduais e em outros parlamentos mirins, como o Plenarinho, na Câmara dos Deputados. Um dos coordenadores fala sobre as numerosas visitas que recebe e as que faz em outros parlamentos, sempre destacando a importância do caráter educativo e do respeito às realidades de cada município. E se nega a corroborar com o interesse eleitoreiro de alguns parlamentares: "nesse caso não posso ajudar, porque não sou seu cabo eleitoral”.

As parcerias se dão em torno de um projeto pedagógico robusto e com objetivos claros. O caráter educativo é sublinhado com o planejamento bem estruturado das atividades. De acordo com um entrevistado, o parlamento mirim não pode se reduzir à teatralização das atividades legislativas: “Fingir que é um vereador não dá resultado. Tem a empolgação inicial, mas, com o tempo, perde a graça. Fingir não é formação de consciência. Os estudantes acabam por reproduzir os vícios do parlamento, seguindo um regimento dos adultos”.

A segunda estratégia, reflexo mais evidente do trabalho dos coordenadores dos parlamentos mirins, é a busca, reunião, documentação e disseminação de informações. Segundo eles, a receptividade das escolas e da comunidade é diretamente proporcional às informações que recebem sobre a relevância da experiência. É necessário romper com a resistência inicial demonstrada pelas escolas, que temem ser transformadas em palanques eleitorais, e pelos pais, que desconfiam de doutrinação ideológica ou da participação dos seus filhos na política, considerada perniciosa. À medida que o programa se solidifica por um projeto pedagógico consistente, as resistências são atenuadas.

Para fomentar a adesão das escolas e o apoio da comunidade local, os coordenadores também investem na exposição midiática, para dar visibilidade ao parlamento mirim e justificar o uso de recursos em algo que não é atividade-fim da câmara municipal. A ideia é que o programa possa 
ultrapassar as fronteiras da casa legislativa, tornando-se um patrimônio, uma "tradição" do município.

Se, para Carpenter (2001), a inovação é uma das capacidades organizacionais que o burocrata deve ter como requisito para sua autonomia, e, para Patterson (1970), ela é a mola propulsora dos estafes no Legislativo, as entrevistas com coordenadores de câmaras mirins mostraram a importância da combinação entre tradição (algo que merece ser mantido e passa a fazer parte da cultura do parlamento e mesmo do município) e inovação (para manter o interesse dos vereadores mirins).

Entre as táticas dos servidores estão: i) a criação de eventos noticiáveis; ii) o envio de sugestões de pauta para mídia externa; iii) o uso dos meios de comunicação e do site da câmara para divulgar os resultados do programa; iv) a produção e distribuição de cartilhas, jornais e outras publicações; $v$ ) a abertura de perfis em redes sociais, para maior interação com o público jovem; e vi) a criação de identidade visual (publicidade, uniformes), demonstrando institucionalização e profissionalismo. As aparições na mídia somam-se como um dos resultados concretos do programa e estimulam os vereadores mirins, ao dar reconhecimento à sua atuação.

A divulgação de informações e a criação e manutenção de parcerias visam a inspirar confiança e obter apoio e legitimidade. Os entrevistados ressaltam que, por extensão, o incremento da imagem positiva do parlamento mirim se reflete num maior conhecimento acerca da câmara municipal por parte dos cidadãos, e de uma mudança, ainda que sutil, em sua visão sobre o Legislativo.

\subsubsection{Efeitos de ações e ideias dos servidores}

Quais os desdobramentos do ativismo dos servidores nos parlamentos mirins pesquisados?

\subsubsection{A aproximação com os vereadores não é suficiente}

De acordo com os autores que estudam o estafe legislativo, parlamentares apoiam a expertise dos servidores que eles sabem que vão ajudá-los em seu trabalho. Eles dependem desses servidores. Por isso, a relação dos 
coordenadores dos parlamentos mirins com os vereadores é tão importante, para que estes vejam o programa como vantajoso e não supérfluo, ou seja, dispensável no primeiro momento em que quiserem alocar recursos. Mas, como visto anteriormente, quando os servidores estreitam o contato com os parlamentares, correm o risco de comprometer o programa na legislatura seguinte.

\subsubsection{A institucionalização não é suficiente. Nem mesmo a edição de uma lei}

O fato de haver um dispositivo jurídico não garante que o programa será implantado, nem se terá continuidade. No levantamento prévio, pelo menos dez câmaras desativaram seus programas, mesmo com a existência de leis municipais.

É contraditório que leis sejam desrespeitadas pela própria casa que as cria e aprova; mas, se é nessa casa que a lei se aplica, e não há nenhum tipo de sanção para o não cumprimento (ainda que houvesse, a revogação também estaria nas mãos de quem deveria obedecê-la), o normativo que regulamenta o parlamento mirim aparece mais como a formalização de um desejo do que um imperativo legal.

\subsubsection{A tradição e a divulgação não são suficientes}

Um dos parlamentos mirins mais antigos do Brasil, entre os poucos existentes na região em que se encontrava, dispunha de espaço destacado no site da câmara municipal, com diversas informações sobre o programa. Na entrevista com o coordenador, em 2015, ele informou que o processo seletivo para as escolas não havia sido aberto porque "o novo presidente da casa precisava se inteirar do programa” para convencer-se de que era válido dar-lhe prosseguimento. O programa foi descontinuado.

Noutro programa, igualmente antigo, o coordenador externou sua apreensão de que, pela primeira vez na história bem-sucedida da câmara mirim em sua cidade, não tinha certeza do prosseguimento. Outro entrevistado comentou que durante o mandato de uma das Mesas, mesmo com a grande 
visibilidade na mídia em anos anteriores, até “o setor de imprensa da casa passou a dar menos cobertura” e o programa perdeu espaço.

\subsubsection{As redes não são suficientes}

Como a participação política infantojuvenil e a educação para a democracia não consistem em "causas” que são objetos de "descontentamento" por parte da sociedade (especialmente escolas, pais e crianças), tampouco "bandeiras" levantadas tradicionalmente pelos movimentos sociais, os coordenadores de parlamentos mirins pouco podem se utilizar das redes externas como mecanismos de pressão sobre os vereadores. Durante o levantamento, houve até quem mencionasse que o então presidente da casa não via problema na extinção do parlamento mirim, "porque isso não prejudicaria sua imagem perante os próprios eleitores”.

As redes também podem gerar efeitos colaterais não previstos. Por exemplo, a parceria com o Poder Executivo envolve detentores de mandato de um certo partido, e as secretarias de educação são coordenadas por pessoas ligadas a projetos políticos. Um dos entrevistados atenta que, no seu caso, isso interferiu no parlamento mirim a ponto de torná-lo objeto de conflito e disputa de poder fora da câmara municipal, principalmente por ter sido bem-sucedido.

\subsubsection{Os valores pessoais dos servidores não são suficientes}

Valores pessoais impulsionam as ações dos servidores e seu envolvimento com as causas nas quais acreditam. Para os comissionados, não há alternativa quando a Mesa muda: eles saem junto. Para os efetivos, há estabilidade. Com o passar do tempo, contudo, as sucessões de mandatos com visões distintas, a hierarquização e a burocratização de gestões, a preterição em nome de interesses pouco nobres, a curteza de objetivos, a redução de recursos e de autonomia, fazem com que os servidores percam o entusiasmo, ou prefiram se dedicar a outros projetos mais promissores.

As palavras de um entrevistado sublinham esse desencanto: 
Sou um militante político. Sempre vou de cabeça, me envolvo em tudo o que faço, anulo minha vida pessoal. Por isso não quis e não quero mais continuar. Pensei em fazer outras coisas, outros desafios, mas não quero nem entrar em mais nada. E também não quero sentir perda quando me aposentar.

\subsection{9 $\bigcirc$ fato é que sobrevivem}

Nenhuma estratégia dos ativistas é suficiente para manter o parlamento mirim - nem a si mesmos. Três anos depois, na segunda rodada de entrevistas, em 2018, nenhum dos coordenadores abordados permanecia à frente do programa. No entanto, por todo esse período, as quatro câmaras municipais ativas selecionadas continuavam com seus parlamentos mirins. Surgem duas constatações: $i$ ) tomadas de modo isolado, as ações podem não ser suficientes, mas a combinação de duas ou mais delas, sim; ii) essa combinação de ações perpetua a ideia, ou causa, que sustenta seu ativismo.

Nos parlamentos mirins das câmaras municipais, por vezes se observa o esforço individual do coordenador responsável. Ele exerce uma liderança essencial. Seu talento para, em estratégias simultâneas, articular as ações em torno da educação para a democracia e institucionalizar o programa, bem como tecer e mobilizar as redes, condiz com o conceito de "habilidade social” de Fligstein (2001). Entretanto, há diferenças entre o empreendedor institucional de Fligstein (2001) e o ativista estudado aqui. O primeiro traz o propalado (e criticado) cunho "heroico", ao passo que o segundo consegue fazer sua influência extrapolar sua própria pessoa. Além disso, Fligstein fala sobre a abertura de várias frentes, na esperança de que pelo menos uma seja exitosa. Nos casos estudados, uma frente potencializa a outra, fazendo com que o conjunto seja bem-sucedido.

Abers (2015) fala de ativistas comissionados que se preocuparam em deixar uma "marca” após sua saída do cargo. Niesz e Krishnamurthy (2013) explicam como a rede faz com que os atores mobilizados se sintam "autores" dos processos e, assim, perpetuem a herança do ativismo mesmo sem a presença dos líderes que o ensejaram. Aqui, vê-se um esforço de despersonalização do líder na institucionalização e na mobilização de 
redes, evitando que seu nome, sua causa e seu trabalho como servidor também criem vinculações e concorrências que possam minar o programa que defendem - e a si mesmos.

\section{Conclusão}

As literaturas de empreendedorismo e ativismo na burocracia questionam o modelo weberiano de neutralidade da administração e de cisão com a política ao revelar servidores públicos que empunham bandeiras e transformam o próprio Estado. No entanto, tais ações continuam profundamente moldadas pela hierarquia, e nisso Weber (1982, 1997, 2012) foi incontestavelmente perspicaz. Este trabalho, que tem por ambiente de estudo os parlamentos mirins no Brasil, mostra como as relações entre servidores e seus superiores políticos podem se tornar contendas ativistas, e como os primeiros buscam recursos de poder simultaneamente em diversas fontes para fazer frente a essas contendas. No caso do Poder Legislativo, a coexistência e a proximidade de superiores de diferentes correntes ideológico-partidárias tornam essa tarefa ainda mais complexa. Some-se, ainda, o desafio de defender uma causa que não reflete uma demanda da sociedade, que é a educação para a democracia.

Coordenar um parlamento mirim não é uma tarefa isenta de percalços como poderia parecer à primeira vista. A aproximação de vereadores com o programa até pode ser legítima, não voltada para fins marqueteiros ou eleitorais. Entretanto, ainda que no início essa aproximação se mostre interessante, depois pode criar problemas para a manutenção do parlamento mirim. Os servidores, então, se empenham em neutralizar as ameaças de dissolução do programa tendo em vista o cumprimento das regras do parlamento mirim para o qual foram nomeados, e que passaram a assumir como valores próprios. Não se trata apenas de dirimir conflitos presentes em qualquer ambiente de trabalho, mas de um ativismo com diferentes contendas - e, nesse ponto, a contenda parece ser o aspecto mais distintivo da ação ativista, que a diferencia de outras ações coletivas.

Mesmo quando há entusiasmo e apoio dos vereadores, a causa “educação para a democracia” enfrenta outras adversidades, resistências, oposições. 
De início, as contendas ocorrem em relação a alvos na sociedade: desconfiança de escolas e pais, imagem desgastada do Legislativo, questionamentos da mídia. Daí o esforço em clarificar o conteúdo pedagógico do parlamento mirim e disseminar informação no município. Longevidade e tradição tendem a criar uma imagem positiva, mas que exige manutenção contínua na medida em que, a cada ano, o projeto recebe novas escolas e novos estudantes.

Com o tempo e as mudanças sucessivas de Mesa, o alvo pode se personalizar e se transferir para um determinado superior hierárquico ou político, ou grupo, que esteja na cúpula da Casa. Nos parlamentos mirins analisados, a contenda "hierárquica" ficou bem assinalada. Mesmo no caso dos comissionados, indicados pelos gestores, existe o desafio de atenuar as marcas político-partidárias que Mesas antecessoras possam ter deixado no parlamento mirim, especialmente quando há “estragos” a reparar.

Por último, a educação para a democracia também tem um alvo abstrato, mais amplo, como a omissão proposital quanto ao letramento político dos cidadãos e o sistema educacional formatado para reproduzir e perenizar a opressão.

De modo geral, há um afastamento dos vereadores reais em relação ao programa. Mas eles precisam ser persuadidos porque, ainda que o parlamento mirim se deva ao empenho pessoal dos coordenadores, ele depende do interesse dos vereadores para ter continuidade. Os servidores, então, buscam um delicado equilíbrio (visto também por Hysing, 2014) no contato com os parlamentares, mostrando-lhes resultados, inclusive como forma de justificar e dar legitimidade às suas ações. Ao mesmo tempo, procuram manter a autonomia institucional do programa. Sem garantias.

Os servidores buscam reforçar tanto seu papel técnico como seu papel neutro (bem ao estilo weberiano), mas apenas na superfície. Se mantêm um distanciamento calculado em relação aos vereadores - que têm poder sobre o programa e podem extingui-lo - aproximam-se de autoridades de outros poderes, bem como de organizações e setores da sociedade. Observam-se neles, nos termos de Olsson e Hysing (2012), uma face iluminada, supostamente "neutra”, e outra escondida, de cunho "político”. Essa última reflete a natureza de seu ativismo, que questiona e por isso ameaça o poder e encontra resistências.

Eles optam por ações “fora do radar” (BANASZAK, 2010), num “ativismo em segredo” (OLSSON; HYSING, 2012), na tentativa de exercer seu “poder 
invisível” (ROSENTHAL; BELL, 2002). No caso das câmaras municipais, a proximidade hierárquica com os políticos dificulta até mesmo esse "segredo".

Lidando com suas "duas faces” no enfrentamento de uma contenda hierárquica, os coordenadores dos parlamentos mirins investem na combinação de duas estratégias para obtenção de recursos na defesa de sua causa: i) a institucionalização das práticas; e ii) a construção de redes dentro e fora do Estado. Separadas, as duas frentes não são suficientes para a sobrevivência do programa, mas talvez sua soma o seja, porque, no fim das contas, todos os programas que a aplicaram sobreviveram. O esforço desses coordenadores, tão individualizado, foi capaz de articular ideias e ações que se perpetuaram mesmo sem sua presença. A despeito de seu papel de liderança, eles acabaram por despersonalizar sua atuação, para preservar tanto o programa ao qual se dedicaram como a sua própria posição na instituição.

Por fim, é complexo avaliar um ativismo que não é voltado para políticas públicas, mas busca a mudança institucional que promova um parlamento e uma sociedade mais justos. Um ativismo que é feito a conta-gotas, num pequeno universo de 10, 20 vereadores mirins por ano, na esperança de que, lembrando as palavras de um dos entrevistados, as crianças possam "fazer um futuro melhor". Mas é fato que a educação para a democracia, que incentiva o exercício da cidadania e a participação política, é também uma causa de combate à desigualdade - que pode estar na raiz da adoção e defesa de várias outras causas.

\section{Referências}

ABERS, Rebecca Neaera. Ativismo na burocracia? O médio escalão do programa bolsa verde. In: CAVALCANTE, Pedro Luiz Costa; LOTTA, Gabriela S. (org.). Burocracia de médio escalão: perfil, trajetória e atuação. Brasília: Enap, 2015.

ABERS, Rebecca Neaera. Bureaucratic activism: pursuing environmentalism inside the Brazilian state. Latin American Politics and Society, v. 66, n. 2, p. 22-44, may 2019. 
ABERS, Rebecca Neaera; TATAGIBA, Luciana. Institutional Activism: Mobilizing for Women's Health from Inside the Brazilian Bureaucracy. In: ROSSI, Federico M.; von BÜLOW, Marisa (org.). Social Movement Dynamics: New Perspectives on Theory and Research from Latin America. London: Ashgate, 2015, p. 73-101

BANASZAK, Lee Ann. The women's movement inside and outside the State. New York: Cambridge University Press, 2010.

CARPENTER, Daniel. Entrepreneurship, networked legitimacy and autonomy. In: CARPENTER, Daniel. The forging of bureaucratic autonomy: reputations, networks, and policy innovation in executive agencies, 18621928. Princeton, NJ: Princeton University Press, 2001.

CASTRO, Ruth Schmitz et al. A quem cabe a formação política dos cidadãos? In: MEDEIROS, Regina de Paula; MARQUES, Maria Elizabeth (org.). Educação política da juventude: a experiência do Parlamento Jovem. Belo Horizonte: Editora PUC Minas, 2012.

COSSON, Rildo. Escolas do legislativo, escolas de democracia. Brasília: Edições Câmara, 2008.

FLIGSTEIN, Neil. Social skill and the theory of fields. Sociological Theory, v. 19, n. 2, p. 105-125, jul. 2001.

HAMMOND, Susan Webb. Legislative staffs. Legislative Studies Quarterly, v. 9, n. 2, p. 271-317, may 1984.

HAMMOND, Susan Webb. Recent research on legislative staffs. Legislative Studies Quarterly, v. 21, n. 4, p. 543-576, nov. 1996.

HYSING, Erik. How public officials gain policy influence: lessons from local government in Sweden. International Journal of Public Administration, v. 37, n. 2, p. 129-139, jan. 2014. 
LOTTA, Gabriela Spanghero. Implementação de políticas públicas: o impacto dos fatores relacionais e organizacionais sobre a atuação dos burocratas de nível de rua no Programa Saúde da Família. 2010. 295 f., il. Tese (Doutorado em Ciência Política) - Faculdade de Filosofia, Letras e Ciências Humanas, Universidade de São Paulo, São Paulo, 2010.

MACEDO, Maria do Carmo Freitas; TELLES, Beatriz Marcos; SILVESTRE, Ana Carolina Faria; FRANCO, Monica Fonseca. Educação cidadã: desafio interdisciplinar. Interdisciplinaridade: Revista do Grupo de Estudos e Pesquisa em Interdisciplinaridade, n. 3, p. 50-61, out. 2013.

MEIER, Kenneth J.; O’TOOLE JR., Laurence. Bureaucracy in a democratic state: a governance perspective. Baltimore: The Johns Hopkins University Press, 2006.

NIESZ, Tricia; KRISHNAMURTHY, Ramchandar. Bureaucratic activism and radical school change in Tamil Nadu, India. Journal of Educational Change, v. 14, n. 1, p. 29-50, feb. 2013.

OLSSON, Jan. The power of the inside activist: understanding policy change by empowering the Advocacy Coalition Framework (ACF). Planning Theory \& Practice, v. 10, n. 2, p. 167-187, jun. 2009.

OLSSON, Jan; HYSING, Erik. theorizing inside activism: understanding policymaking and policy change from below. Planning Theory \& Practice, v. 13, n. 2, p. 257-273, jun. 2012.

PATTERSON, Samuel C. The professional staffs of congressional committees. Administrative Science Quarterly, v. 15, n. 1, p. 22-37, mar. 1970. PETTINICCHIO, David. Institutional activism: reconsidering the insider/ outsider dichotomy. Sociology Compass, v. 6, n. 6, p. 499-510, jun. 2012. PRICE, David E. Professionals and “entrepreneurs": staff orientations and policy making on three Senate committees. The Journal of Politics, v. 33, n. 2, p. 316-336, may 1971. 
ROSENTHAL, Cindy Simon; BELL, Lauren Cohen. Invisible power: congressional staff and representation behind the scenes. In: ROSENTHAL, Cindy Simon (Ed.). Women transforming Congress. Norman: University of Oklahoma Press, 2002.

SANTORO, Wayne A.; MCGUIRE, Gail M. Social movement insiders: the impact of institutional activists on affirmative action and comparable worth policies. Social Problems, v. 44, n. 4, p. 503-519, nov. 1997.

VEREADORA mirim é censurada pela presidente da Câmara Municipal de Juara ao cobrar melhorias à administração municipal. Arinos Notícias, Tabaporã, 11 jun. 2011. Disponível em: http://www.arinosnoticias.com. br/noticia/347/Vereadora-mirim-e-censurada-pela-presidente-da-CamaraMunicipal-de-Juara-ao-cobrar-melhorias-a-administracao-municipal/5. Acesso em: 1 nov. 2017.

WEBER, Max. Ensaios de sociologia. Rio de Janeiro: LTC Editora, 1982. WEBER, Max. Textos selecionados. Coleção Os Economistas. São Paulo: Nova Cultural, 1997.

WEBER, Max. O que é a burocracia. Brasília: Conselho Federal de Administração, 2012.

ZWARICH, Jennifer. The bureaucratic activist: federal filmmakers and social change in the U.S. Department of Agriculture's tick eradication campaign. The Moving Image, v. 9, n. 1, p. 19-53, jan. 2009. 


\section{Capítulo 9}

\section{Entre a inclusão e a exclusão: criatividade em contextos de controvérsias}

Paula Pompeu Fiuza Lima

Os programas sociais focalizados têm em seu cerne um conflito fundante: seria melhor afrouxar as regras de participação no programa, correndo o risco de incluir indevidamente alguém fora do perfil mas buscando abarcar todo o público-alvo, ou enrijecer as regras de entrada e permanência no programa arriscando excluir quem está dentro do perfil? Em termos técnicos, é um conflito entre priorizar o erro de exclusão ou de inclusão. Sendo um programa social focalizado, o Programa Bolsa Família (PBF) depara-se com esse conflito diariamente. E é o Cadastro Único para Programas Sociais que possibilita que a entrada e saída das famílias no programa se dê com maior ou menor dificuldade.

O Programa Bolsa Família é um programa de transferência de renda condicionada que visa promover o alívio imediato à pobreza e extrema pobreza e quebrar o ciclo intergeracional de pobreza por meio do provimento de serviços de saúde, educação e assistência social. O Cadastro Único é o registro administrativo que coleta as informações das famílias 
que pleiteiam participar do programa e fornece esses dados aos gestores que verificam se a família tem ou não o perfil para ser beneficiária.

Ganhando cada vez mais visibilidade ao longo dos governos petistas, o Programa Bolsa Família foi alvo de diversas disputas. O conflito entre erro de exclusão e inclusão esteve presente desde o primeiro ano do governo, e causou sua primeira crise de legitimidade quando diversas denúncias apareceram nos noticiários mostrando pessoas fora do perfil recebendo o benefício como, por exemplo, políticos, e até mesmo um gato.

A solução encontrada para blindar politicamente o programa foi entregá-lo, junto ao Cadastro Único, nas mãos de uma equipe de gestores de carreira e dar grande autonomia a esses técnicos para desenvolver soluções para os desafios da política. Aparentemente essa solução foi bem-sucedida, porque muitas das análises sobre a gestão do programa no nível federal reforçam o caráter inovador de vários dos arranjos implementados (OLIVEIRA; LOTTA, 2015).

Considerando as análises que indicam o caráter inovador da gestão do programa, a pergunta que orienta este capítulo é: a experimentação criativa ocorre da mesma forma em todos os contextos? Dito de outra forma: diferentes contextos favorecem diferentes tipos de ação criativa? Quais contextos favorecem quais tipos de ação criativa? Para responder a essas perguntas olharei para três contextos diferentes na implementação do programa Bolsa Família e do Cadastro Único, tentando ressaltar que tipo de inovação foi possível em cada um deles.

O primeiro contexto é o de formulação do programa, quando, nas palavras dos próprios gestores, "se buscava trocar os pneus com o carro andando”. Como indicam Oliveira e Lotta (2015), trata-se da fase heroica do programa, quando tudo estava em construção e a equipe de médio escalão tinha grande autonomia para propor e implementar arranjos experimentais. O segundo contexto foi quando surgiram os primeiros grandes questionamentos dos órgãos de controle sobre a qualidade dos dados do Cadastro Único e a focalização do programa. Mais do que desenvolver arranjos experimentais, a equipe da Secretaria Nacional de Renda de Cidadania (Senarc), gestora do programa, precisa justificar as decisões tomadas com argumentos e normativas. É um momento em que são feitos questionamentos por atores externos, mas o corpo burocrático ainda possui 
grande respaldo interno. Por fim, o terceiro momento é o pós-impedimento da presidenta Dilma Rousseff, quando aqueles que indagam a focalização do programa passam a fazer parte do governo. É um contexto em que os questionamentos internos se somam aos externos.

A maior parte dos dados apresentados foi coletada por meio de entrevistas com os gestores de médio escalão da Senarc e refletem, desse modo, a visão deles. Até o momento foram feitas entrevistas com 12 servidores ou ex-servidores da Senarc. Os ex-gestores foram contatados porque ao longo da pesquisa identificou-se a necessidade de compreender melhor o que motivou algumas das práticas da forma como foram feitas. Duas das entrevistas com servidores foram exploratórias, ou seja, foram baseadas em um roteiro mais livre que possibilitasse identificar questões mais específicas a serem aprofundadas. Elas foram utilizadas no capítulo porque as respostas contribuíam para os objetivos da pesquisa. Todos os entrevistados estão apresentados como mulheres, o que favorece o anonimato dos atores e contribui para uma linguagem inclusiva. É importante ressaltar que sou também servidora da Senarc, o que pode ter enviesado a escolha de alguns dos entrevistados. Tentei minimizar esse efeito buscando incluir na análise atores com poder significativo de decisão, como secretários e ex-secretários, diretores e ex-diretores de departamentos, coordenadores-gerais envolvidos nas ações de averiguação do Cadastro Único e assessores que estão na Senarc há muito tempo e têm memória de muitas das decisões tomadas. Todos os servidores entrevistados possuem ou possuíam no momento em que estavam na Senarc cargos de direção e assessoramento 4, 5 ou 6, i.e., compõem uma elite dirigente do órgão.

O capítulo está dividido em duas seções, sem contar esta introdução e a conclusão. A primeira delas apresenta o marco teórico que norteia as análises. A segunda explora como se deu a experimentação criativa na gestão do Cadastro Único e do Programa Bolsa Família em três diferentes contextos. A partir desse percurso, busco desenvolver como contextos e conflitos podem ser utilizados para compreender a experimentação criativa. 


\section{Contextos conflituosos, soluções criativas}

Compreender a ação criativa significa entender como a agência dos atores se situa em estruturas. Para isso, considera-se que é porque o ator está inserido em estruturas que ele tem recursos que podem modificá-las. Embora as estruturas condicionem a agência, elas só existem porque existe agência (SEWELL JR., 1992).

Nessa perspectiva, a teoria pragmatista contribui para a análise porque compreende que a ação criativa é motivada pela identificação de problemas e pela tentativa de sua resolução. É um processo cotidiano porque os indivíduos sempre se deparam com situações sobre as quais não sabem o que fazer. Nesse processo, os atores utilizam sua inteligência e sua capacidade de construir hipóteses não convencionais para solucionar questões com as quais se deparam. A partir desse processo os atores constroem novos jeitos de agir baseados na reflexão sobre hábitos antigos (JOAS, 1996).

O constante questionamento das próprias premissas permite que o indivíduo aprenda a antecipar problemas, não somente reagindo a situações com as quais se depara (ANSELL, 2013). Isso ocorre porque a capacidade de interpretação das situações ocorre durante a interação social, seja na interação face a face entre indivíduos concretos, seja na interação com categorias abstratas, como o Estado. E nessa interação, o indivíduo se coloca no lugar da pessoa ou coisa com a qual ele interage, tornando-se capaz de imaginar qual a reação desse ator em relação àquele que o interpela (BLUMER, 1969).

Esse processo não se dá sem conflitos, nem sempre o que é considerado problema para alguém é considerado por outra pessoa. Assim, a construção de um problema é permeada por esforços de justificação e acionamento de critérios de justiça. É por meio da comparação da situação vivida com um critério de justiça mais amplo que uma situação é identificada como problema. $\mathrm{O}$ ator, nesse sentido, é um sujeito dotado de capacidade crítica, capaz de argumentar e justificar seus atos de acordo com um senso de justiça ordinário (BOLTANSKI; THÉVENOT, 1999).

Os critérios de justiça, no entanto, nem sempre são os mesmos. Quando há diferentes critérios de justiça, cria-se uma situação de descontentamento ou uma disputa, e uma necessidade de justificação. Para isso 
são utilizados diferentes valores, que podem ser utilizados para justificar ações inseridas em distintos contextos, concordando ou não com outros atores. Assim, a experimentação de novas soluções não se dá somente com base em um questionamento neutro das próprias premissas, mas se dá em um ambiente permeado por valores que são constantemente contrapostos e que justificam as ações (BOLTANSKI; THÉVENOT, 1999).

Por meio de uma visão ecológica das estruturas, a teoria pragmatista situa a agência criativa. O contexto não é somente um limitador da ação, até porque não existe apenas um contexto que circunda o sujeito, mas diversos níveis de contextos, alguns mais imediatos, outros mais sistêmicos. Isso pressupõe uma explicação multinível, que requer também a existência de estruturas de intermediação entre esses níveis. Os atores situados nessas estruturas de intermediação teriam maior capacidade de ação criativa, visto que sua posição favorece a utilização dos diferentes recursos apontados. Isso significa que esses atores têm maior capacidade de identificar como se dá a distribuição e a diversidade dos elementos no tempo e no espaço para conectá-los e situá-los em processos já em curso (ANSELL, 2013).

A utilização da teoria pragmatista a partir de uma visão ecológica indica um processo em que, por um lado, dependendo das situações com as quais os atores se deparam, diferentes soluções são propostas; por outro, dependendo dos atores com os quais os sujeitos interagem e para os quais precisam justificar suas ações, argumentos diversos são acionados e ações distintas são propostas baseadas nos valores em disputa. Além disso, o contexto contribui para a explicação das ações, não sendo sempre um limite para a mudança, como nas descrições sobre dependência de trajetória. Existem multiescalas de contextos que afetam as ações de diferentes formas e uma evolução de contexto pode possibilitar uma ação que não seria possível em um momento anterior, não somente em função da trajetória passada, mas simplesmente porque o contexto não é estático.

Essa perspectiva difere da comumente utilizada nos estudos sobre burocracia e instituições políticas, mas não se desloca completamente dela. A teoria institucionalista, por exemplo, indica que a agência dos atores é mais perceptível em períodos de crise, que são vistos como janelas de oportunidades para empreendedores políticos emplacarem suas pautas (KINGDON, 2015). A própria literatura sobre empreendedorismo político ressalta o papel 
das instabilidades, mesmo as mais cotidianas, para que os atores possam agir de forma a modificar as instituições (SHEINGATE, 2003).

Por isso, diferencio os processos de evolução dos de ruptura. Evolução do contexto seriam as mudanças menos radicais que dizem respeito a um período curto (embora possam ser muito radicais se considerarmos um período longo), que possibilitam que as capacidades construídas ao longo do desenvolvimento da política encontrem respaldo no mundo externo ou sejam até mesmo impulsionadas por esse mundo externo. Nem sempre é possível indicar se é o desenvolvimento da política que motiva mudanças no contexto ou se são os desenvolvimentos dos atores que interagem com a política que geram mudanças na política, o que dá um sentido de coevolução da política e do ambiente que a cerca.

Ruptura, por outro lado, se refere às crises institucionais que modificam mais profundamente o ambiente que cerca a política. Nessas situações, os desafios postos aos atores podem mudar completamente, exigindo maior capacidade de encontrar soluções criativas. Para este capítulo, contudo, considero que os períodos de instabilidades são aqueles nos quais os atores se deparam com desafios mais complexos, e a crise, em si, não é suficiente para compreender seus desdobramentos. Isso porque, se a instabilidade favorece o empreendedorismo político, ela não indica quem o exercerá, ou seja, o empreendedor político pode ser tanto aquele que questiona as instituições quanto aquele que quer defendê-la. Os desafios são postos para todos de maneira diferente, mas nenhum deles tem uma resposta pronta para esses desafios. Depende, em grande parte, da capacidade dos atores de motivar a cooperação de outros para a sua solução proposta (FLIGSTEIN, 2001).

Para este texto, considero os burocratas da Senarc como ocupantes dessa posição de intermediação. Não são como burocratas de nível de rua que, embora tenham discricionariedade, não têm a competência para criar regras e procedimentos para além daqueles que estão permitidos ou orientados a organizar. São atores com autoridade para propor novos procedimentos e até regras que podem virar leis e normativas que vinculam toda a estrutura de implementação do Cadastro Único e PBF. Embora possuam alguma autoridade e as vantagens da intermediação, estão inseridos em um sistema que envolve diferentes atores, como órgãos de controle, políticos, entre outros. 
Também considero o conflito entre erro de exclusão e de inclusão apresentado na introdução como um conflito de valores que requer justificação de ambas as partes. Se utilizarmos a classificação dos critérios de justiça apontados por Boltanski e Thévenot (1999) podemos considerar que a defesa da prevenção do erro de inclusão tem a ver com uma lógica industrial que tem a eficiência como valor principal. Por outro lado, a defesa da prevenção do erro de exclusão se alinha mais a uma lógica cívica, que preza pela solidariedade e o interesse coletivo. É a partir dessa diferença entre critérios de justiça que se estabelece boa parte dos esforços de justificação que envolve as decisões tomadas pelos gestores do Cadastro Único e PBF.

Assim, a mudança ou manutenção de uma instituição ocorrerá em função da capacidade de os atores realizarem experimentos criativos que solucionem os problemas postos e darem sentido às suas ações para atores externos e para eles mesmos. Ocorrerá também a partir do momento em que se identifica que capacidades antes inexistentes passaram a existir, e que se pode aproveitar a oportunidade para realizar mudanças.

Essa pesquisa se difere de alguns dos estudos sobre o Cadastro Único e o Programa Bolsa Família que foram eficientes em mostrar os processos iniciais de formação dessas políticas mas analisaram pouco a atuação dos burocratas (ANDRADE; LIMA-SILVA, 2016). Ou mesmo de estudos que reforçam o papel do insulamento burocrático que possibilitou o desenvolvimento dessas políticas, mas se restringem a um período muito específico em que os conflitos não estavam tão presentes e o esforço dos atores para resolver os problemas decorrentes desses conflitos não era tão evidente (OLIVEIRA; LOTTA, 2015). Distancia-se, ainda, de estudos que buscam analisar o papel dos burocratas de nível de rua do PBF e Cadastro Único e suas percepções a respeito da política e de seus usuários (EIRÓ, 2015), pois essas pesquisas não são úteis para entender um conjunto de atores muito mais restrito e com bastante poder de decisão como são os burocratas de médio escalão.

\section{Experimentação criativa em diferentes contextos}

O marco teórico utilizado reforça o papel da criatividade para explicar a mudança institucional. Indica também que a criatividade não se dá isolada 
do contexto, e que o fato das situações terem múltiplas escalas e perspectivas é que dá aos atores elementos para agirem criativamente. Nesta seção são apresentados três contextos diferentes e os experimentos criativos possibilitados por cada um deles. Todos esses contextos são permeados por disputas de ideias sobre o que se deve priorizar, o erro de exclusão ou de inclusão, mas essa disputa acontece de diferentes formas. Embora a apresentação se dê a partir dos contextos escolhidos, não se considera que é o contexto que define que tipo de experimento pode ser realizado. O que se busca com esta seção é demonstrar como a evolução de uma política pública (na verdade, duas políticas imbricadas) interage com as evoluções e rupturas de contextos, modificando os tipos de experimentos criativos.

\subsection{Primeiro contexto: problemas a serem resolvidos e respaldo interno}

O primeiro contexto a ser apresentado é o de formulação do programa Bolsa Família e Cadastro Único. Logo no primeiro ano de execução do PBF, houve uma crise de confiança no programa devido a várias denúncias de fraudes e irregularidades (VIEIRA, 2011; LICIO, 2012). A Secretaria Nacional de Renda de Cidadania (Senarc), responsável pela gestão do programa, foi pressionada a qualificar os registros do Cadastro Único. Para isso foram definidas duas ações: a primeira consistiu em um série de averiguações cadastrais, que são cruzamentos da base de dados do Cadastro Único com outros registros administrativos que trazem informações de renda e composição familiar - como registro de trabalhadores inseridos no mercado de trabalho formal, de pessoas que recebem benefícios previdenciários e trabalhistas e de óbito - com o objetivo de verificar se a renda declarada no Cadastro Único é semelhante à renda inscrita nos outros registros; a segunda solução foi a criação de um pagamento aos municípios por registro feito no Cadastro Único que cumpriam todos os requisitos de qualidade da informação. Ao longo do tempo, esse pagamento por cadastro passou a fazer parte de um repasse financeiro feito aos municípios que remunera o desempenho aferido em atividades necessárias à gestão do Programa Bolsa Família, entre elas o cadastramento das famílias.

A primeira solução buscava resolver o principal problema do Bolsa Família: como viabilizar um programa que tinha a ambição de abarcar todas 
as famílias pobres e extremamente pobres do país. O próprio Programa Bolsa Família surge como um esforço de resolução do fracasso de um programa tido como mais completo para uma das servidoras, o Programa "Fome Zero". Para ela, não havia a possibilidade de parar para pensar no que fazer a partir desse fracasso. Como afirmou uma ex-gestora:

Tem que entender também a trajetória, a coisa do fome zero já tinha naufragado. E a coisa do fome zero era muito mais digamos próxima das realidades das pessoas, e era muito mais envolvente, envolvia as produções locais etc. Então essa solução Bolsa Família, transferência de renda era uma solução mais acachapante, vamos lá, nós temos que fazer acontecer, vamos registrar as pessoas e vamos pegar as suas declarações e vamos pra frente. (Entrevista realizada em 9 out. 2017).

Embora houvesse um problema a ser resolvido, não havia em nível federal nem em nível municipal uma estrutura responsável por executar esse registro conforme as experiências de outros países, ou seja, a partir de visitas domiciliares ou coletando informações suficientes das famílias que possibilitasse a utilização de means proxy, que são métodos de aferição da pobreza por meio de diferentes características da família, como despesas, patrimônio, escolaridade, para além do trabalho e renda. De acordo com uma ex-gestora, chegou-se a cogitar a contratação do IBGE para realizar o cadastramento das famílias, o que foi descartado a partir da decisão política de fortalecer os municípios.

A partir da necessidade de construção de regras simples para operacionalizar o programa em larga escala, surge o conceito de autodeclaração, que passa a ser fundante em toda a compreensão de quais dados podem ser utilizados para conceder benefícios do Bolsa Família e dar acesso a outros programas sociais. A autodeclaração significa que os dados registrados no Cadastro Único serão declarados por um responsável pela família, sem a necessidade de comprovação documental nem de checagem por um servidor público por meio de visitas domiciliares.

A renda declarada passou a ser principal informação utilizada para definir quem é habilitado a receber o benefício ou não. Ia na contramão de outros 
programas de transferência de renda latino-americanos, que utilizavam os means proxy. Por outro lado, não se diferenciava significativamente de outros registros, como a declaração para fins de imposto de renda, em que a pessoa declara a sua própria renda e só precisa comprovar o declarado caso seja identificada alguma inconsistência. Como afirma uma entrevistada:

Eu acho que a autodeclaração olhando a posteriori [...] é uma pegada do que é possível ser feito. [...] Essa a minha visão, óbvio, escuta: nós estamos no Brasil, num país de milhões e milhões de pessoas onde tem milhões e milhões de pobres morrendo de fome agora! [...] É uma coisa meio prática, assim. Precisamos agora dar dinheiro para as pessoas que estão morrendo de fome. [...] Depois a gente foi elaborando a posteriori, olha, por que não ser autodeclarado? Afinal, pra todo o resto é autodeclarado, você percebe que todo o resto é autodeclarado, a não ser os salários ganhos no setor privado, que é o empregador que declara pra você. Aí a gente foi sofisticando esse entendimento e delimitando bem esse conceito. (Entrevista realizada em 9 out. 2017).

O relato da entrevistada ilustra bem o processo de experimentação que gerou a ação criativa. No caso, os servidores da Senarc tinham um grande problema à sua frente, que era o de registrar milhões de famílias para cumprir a meta de incluí-las em um programa que tinha a ambição de erradicar a pobreza no Brasil. Para isso, construíram novos conceitos que passaram a estruturar todo o Cadastro Único e a forma como os beneficiários do PBF e de outros programas que posteriormente iriam utilizar o Cadastro Único seriam habilitados.

A solução da autodeclaração trouxe um problema: se a informação é declarada pela família, como garantir que as famílias não vão mentir a renda para conseguir se habilitar ao programa? É comum que registros autodeclarados tenham algum tipo de checagem de dados, a exemplo da malha fina da Receita Federal para a declaração de imposto de renda. Isso, aliado à precariedade com a qual a junção das bases de dados dos programas que deram origem ao PBF foi feita, trouxe grandes questionamentos a respeito da qualidade dos dados do Cadastro Único e a consequente focalização do PBF. De acordo com uma entrevistada: 
Você tem muita crítica ao Bolsa Família, muita na mídia. Era paulada de que não havia focalização, os benefícios eram justapostos, sobrepostos, então quando se pega o Cadastro, a que não se tinha acesso até então. Então o Cadastro chega no MDS no início de 2005, de fato você vê que era um cadastro que não permitia nem a atualização de registro. Então se tu tivesses que atualizar o teu, tu entravas duplicado. Então tinha muita família fora, família duplamente dentro. Então você precisava analisar minimamente aquilo ali. (Entrevista realizada em 31 out. 2017).

As ações de averiguação cadastrais surgiram em 2005 em decorrência dessas denúncias de famílias que recebiam o benefício do PBF indevidamente. O Tribunal de Contas da União (TCU) e a Controladoria Geral da União (CGU) tiveram um papel importante nesse período, visto que a averiguação surgiu também como resposta a recomendações feitas por estes órgãos (VIEIRA, 2011). Ao longo dos anos, as averiguações cadastrais foram tomando corpo e desenvolvendo procedimentos cada vez mais padronizados de encaminhamento. Contudo, esse processo não é linear, e será melhor explicado a partir da apresentação dos outros contextos.

Ao normatizar a estrutura implementadora do PBF e do Cadastro Único, decide-se por delegar aos municípios o cadastramento das famílias. Essa decisão se insere no bojo das ações de descentralização na implementação de políticas públicas que vem desde a constituinte. Teve como protagonista a secretária da Senarc, Rosani Cunha, escolhida por Patrus Ananias para solucionar a crise de legitimidade por ser uma gestora de carreira que conciliava conhecimento técnico e experiência com o movimento municipalista. ${ }^{1}$ Assim como a autodeclaração, definir como competência dos municípios a realização dos cadastros que dariam acesso a

1 O Movimento Municipalista luta por maior descentralização política pró-municípios e o equilíbrio federativo (BATISTA, 2008). 
benefícios sociais foi uma decisão que ia na contramão de políticas com perfil semelhante. ${ }^{2}$

Tanto a autodeclaração com checagem a posteriori (averiguação cadastral) quanto a delegação da competência de cadastramento aos municípios e a consequente viabilização dessa atribuição ${ }^{3}$ foram soluções altamente inovadoras, visto que se diferenciavam tanto de modelos internacionais que poderiam inspirar o Programa Bolsa Família e Cadastro Único quanto de práticas normalmente realizadas na administração pública e que buscavam resolver problemas complexos. Essas soluções foram possíveis pela urgência do problema a ser resolvido, mas principalmente pelo respaldo interno que os gestores tinham dentro do Ministério do Desenvolvimento Social. De acordo com uma entrevistada:

Naquela época a gente tinha muita liberdade para criar, tinha respaldo. Não era simples você vender uma ideia não, pro ministro. Mas uma vez que ele se convencesse que era por aí, não ficava querendo saber de detalhes de portaria. Ele confiava na Conjur dele, confiava na assessoria de controle interno, que eram de fato pessoas muito sérias, que teve um papel fundamental na estruturação do MDS, e confiava na gente, de que a gente ia colocar no papel aquilo que de fato estava mostrando no gabinete do ministro. (Entrevista realizada em 27 abr. 2017).

2 No Brasil, o principal órgão que provê um registro administrativo utilizado para dar acesso a benefícios sociais é o Instituto Nacional de Seguro Social (INSS). Nesse caso, a instituição é federal, descentralizada nos municípios. Todas as responsabilidades relacionadas ao registro, seleção e concessão de benefício é feita por servidores ligados ao governo federal.

3 Para viabilizar o cadastramento das famílias pelos municípios, o governo federal passou a remunerar os municípios por cadastro realizado dentro dos requisitos estipulados. Após algum tempo essa remuneração foi institucionalizada a partir o Índice de Gestão Descentralizada, que reúne indicadores de qualidade do cadastramento e do acompanhamento de condicionalidades do PBF e é utilizado para calcular um valor de repasse financeiro aos municípios (BICHIR, 2011). 
No início do PBF e do Cadastro Único, havia um vazio de regulamentação, e foram os próprios servidores que construiriam essa regulamentação. Muitas das principais características atuais dessas duas políticas não existiam; a construção dos instrumentos de gestão do PBF e do Cadastro Único foram possíveis por meio da experimentação.

Essa possibilidade de experimentação sem muitas amarras se deu, de acordo com Oliveira e Lotta (2015), devido à estratégia de insulamento burocrático da Senarc, que teve como principal característica a garantia de autonomia do corpo burocrático formada principalmente por atores com grandes conhecimentos em gestão pública. Diferentemente de outras políticas do próprio Ministério, a equipe da Senarc tomava as principais decisões referentes ao desenho do programa de forma autônoma, sem consultar atores interessados, como representações de estados e municípios ou da sociedade civil (LICIO, 2012). Mesmo que outros atores tenham sido envolvidos na gestão do Cadastro Único e Programa Bolsa Família, esse envolvimento se deu por meio da adesão e na operacionalização dos procedimentos decididos pelos técnicos da Senarc, e não no compartilhamento de decisões.

Não se pode negar, também, os valores da equipe que se formou em torno dessas duas políticas. De acordo com uma entrevistada:

Eu não consigo identificar na equipe alguém que tivesse uma preocupação com erro de inclusão maior do que o erro de exclusão. [...] não tem nada que se chegue próximo a um perfil conservador de política pública, entende? (Entrevista realizada em 31 out. 2017).

Assim, havia uma predisposição da equipe de gestores de encontrar soluções que minimizassem o erro de exclusão, e isso significava afrouxar as regras de inclusão, como a decisão pela autodeclaração. Outra equipe com tal grau de autonomia poderia ter chegado a soluções completamente diferentes se fosse norteada por outros valores. No caso em pauta, os atores foram possivelmente recrutados por compartilhar valores com a direção escolhida, visto que, de acordo com uma entrevistada: “Quando a Rosani Cunha, que era gestora, saiu da Casa Civil, ela trabalhava na Casa Civil, foi ser a titular da Senarc, ela trouxe um grupo de gestores muito grande. [...] Até então o MDS não tinha quadro” (Entrevista realizada em 5 mai. 2016). 
Ao mesmo tempo, enquanto existia um grupo de servidores com autonomia para tomar decisões que resolvessem os problemas enfrentados, havia uma Secretária que intermediava diferentes níveis: tinha interlocução com o ministro e com os municípios aos quais se delegava a implementação do registro das famílias. É possível considerar que somente o conhecimento técnico dos gestores não seria suficiente para desenvolver soluções tão inovadoras para os problemas enfrentados, até mesmo porque as possibilidades de emulação de outras experiências não levavam às soluções encontradas. Essas, por sua vez, foram possíveis porque a principal autoridade da secretaria era responsável pela interlocução com os municípios, ciente de que não havia estrutura para o registro das famílias utilizando os procedimentos definidos em outros países, mas com a confiança de que com algum apoio e flexibilidade nas regras de coleta dos dados eles poderiam ser protagonistas nessa tarefa.

Foi um contexto em que a equipe estava imersa em um ambiente conflituoso, contudo, uma das soluções dadas para esse conflito foi o próprio insulamento da equipe que geria o programa. Os problemas eram urgentes, e as soluções não eram óbvias, muito menos apolíticas, embora tenham uma justificativa tida como técnica para cada uma delas. Dar a possibilidade de a família autodeclarar a sua situação requer um valor ligado à facilitação das formas de acesso ao programa. Atribuir a responsabilidade de coleta de informações aos municípios facilitando o repasse de recursos para viabilizar essa coleta pressupõe uma confiança nas capacidades municipais. Esse afrouxamento dos controles sobre a família e sobre o município será questionado pelos órgãos de controle, e é nesse contexto que se inserem as próximas inovações.

\subsection{Segundo contexto: questionamento externo e respaldo interno}

Não se pode definir quando se inicia o segundo contexto, mas um marco foi elencado por alguns dos entrevistados: a primeira grande averiguação, em 2009, ocorrida por demanda do Tribunal de Contas da União (TCU), que expôs o Programa Bolsa Família como um programa que beneficiava famílias com posses caras, como carros. De acordo com uma entrevistada, naquele ano os resultados da averiguação foram muito impactantes: 
E o batimento com o Renavam (Registro Nacional de Veículo) foi muito chocante pra nós. Foi o primeiro feito. Porque expuseram o programa na mídia como um programa que tinha gente com 20 caminhões, que tinha um Ford Focus, tal. E a Lúcia era diretora do Cadastro, optou por ir a campo, amostralmente, e por fazer um aplicativo. [...] Quando se foi a campo no Renavam, obviamente em uma amostra não probabilística, a gente foi em poucos casos, o que se viu foi que uma família que tinha 20 caminhões, se ela tivesse, era melhor ela dormir num dos caminhões. Moravam num barraco. (Entrevista realizada em 31 out. 2017).

As soluções encontradas nesse contexto foram a argumentação e o levantamento de evidências para tal. Para isso, os gestores do Cadastro Único buscaram formas de demonstrar que o problema não estava no Cadastro Único, e sim nas outras bases de dados com as quais o cadastro estava sendo comparado. A visita a campo teve esse propósito e é vista por alguns dos gestores como um marco no entendimento de que a autodeclaração podia ser melhor do que as informações contidas em outros registros.

A atuação dos órgãos de controle, na verdade, acaba por ser uma constante em todo o processo da construção das averiguações cadastrais. Em algumas situações eles estavam correndo atrás da equipe da Senarc em desvantagem técnica, em outras eles publicizavam fatos que, por mais que não fossem conclusivos, fragilizavam a gestão do PBF e o Cadastro Único. O papel desses órgãos foi crescendo ao longo do tempo, na medida em que a própria equipe da Senarc conseguia antecipar algumas das demandas que poderiam ser feitas por eles. Ao longo das entrevistas, os órgãos de controle eram vistos como atores que forçavam a Senarc a responder sobre os erros de inclusão, acionando valores menos priorizados pelos gestores. Essa é uma dinâmica que se intensifica na medida em que os órgãos de controle vão adquirindo maior capacidade técnica e força política.

Internamente, na Senarc havia uma divisão de tarefas em que o departamento de Cadastro Único respondia os questionamentos do TCU e o departamento ligado às ações de fiscalização do programa respondia os questionamentos da Controladoria Geral da União (CGU). Enquanto o departamento do Cadastro Único adquiria cada vez mais habilidade para 
demonstrar a consistência dos processos de checagem de dados ao TCU, a CGU, que tinha uma visão mais punitivista, de acordo com uma servidora, foi adquirindo recursos e argumentos para questionar de forma cada vez mais incisiva os procedimentos adotados.

Nessa divisão de tarefas, o departamento responsável pela fiscalização não tinha todos os argumentos necessários para responder questões como: por que não é dado um tratamento mais duro para as famílias que sempre são identificadas em averiguações cadastrais? Essas questões só passaram a ser respondidas a partir da mobilização, por parte desse departamento, dos demais departamentos.

Concomitantemente, se no início do Programa Bolsa Família a prioridade era facilitar o acesso das famílias ao Cadastro Único, com o passar do tempo observou-se que em muitos municípios a estimativa de famílias pobres e extremamente pobres já estava incluída no Cadastro Único. Considerando que era essa a estimativa que subsidiava o cálculo do total de benefícios disponível aos municípios, isso significava que se as estimativas não fossem atualizadas, o programa não poderia mais crescer até não haver mais ninguém identificado como pobre. ${ }^{4}$ Foi nesse período que se começou a identificar uma "fila de espera" para participar do programa, visto que o total de benefícios estimados como suficientes para erradicar a pobreza e extrema pobreza já estavam sendo atingidos em diversos municípios.

Para os gestores do programa, isso trouxe uma lógica de que, para além do problema de focalização, manter uma pessoa fora dos critérios dentro do PBF seria tirar a oportunidade de outra pessoa de participar do programa. Assim, construiu-se a narrativa de que a boa focalização do programa seria necessária para incluir justamente as pessoas que mais precisavam. Logo, para contemplar os mais necessitados, fazia-se necessário excluir os menos pobres. Como afirma uma entrevistada:

4 Essa característica não é inerente a programas focalizados. O Benefício de Prestação Continuada, que concede um benefício para idosos e pessoas com deficiência inseridos em famílias de baixa renda, não tem um limite de benefícios. Por ser um direito previsto em lei, qualquer pessoa que cumpra os requisitos receberá o benefício, independentemente de a estimativa de famílias com o perfil já ter sido contemplada ou não. 
Então acho que a averiguação sempre viveu nessa dubiedade, uma que é a dubiedade, que você tem uma meta de 11 milhões de famílias, você tem que cuidar de incluir as pobres [...]. Então estar alguém que não devia era de fato não estar alguém que devia. Então ela tem a dubiedade da inclusão e da exclusão. (Entrevista realizada em 31 out. 2017).

Dessa forma, os questionamentos externos feitos pelos órgãos de controle e as avaliações internas dos próprios gestores sobre a focalização do programa motivou a construção de normativas e orientações cada vez mais padronizadas de encaminhamento. Em 2015, os gestores da Senarc sistematizaram os procedimentos utilizados na averiguação cadastral, conectando-os com outros procedimentos de qualificação dos dados do Cadastro Único, como a revisão dos registros desatualizados há mais de 24 meses e a exclusão lógica dos registros desatualizados há mais de 48 meses. Nesse momento foram definidos critérios de gravidade da inconsistência cadastral, como a reincidência em averiguações cadastrais, que deram margem para o tratamento diferenciado de famílias com inconsistências consideradas pelos gestores como mais graves. Nesse ano, o público chamado a atualizar o cadastro em decorrência da averiguação cadastral dobrou em relação ao maior público convocado nos anos anteriores.

A lógica da sistematização feita em 2015 foi repetida nos anos seguintes. Contudo, os critérios de gravidade das inconsistências e os encaminhamentos a serem dados para cada grupo foram atualizados a cada ano, visto que não havia uma normatização geral que indicasse quais tipos de inconsistência são mais graves do que outras, e sim decisões específicas a partir da análise dos resultados de cada ação de averiguação cadastral.

Essa normatização, contudo, não resolveu todos os questionamentos feitos pelos órgãos de controle. Se os procedimentos de averiguação se tornam mais sistemáticos e precisos, fica cada vez mais difícil diferenciar uma informação inconsistente em função da desatualização do cadastro da família de uma atitude de má fé da família no momento de prestar informações ao Cadastro Único. As distinções entre averiguação cadastral e 
fiscalização ${ }^{5}$ tornam-se cada vez mais esfumaçadas e os órgãos de controle passam a questionar não só a autodeclaração mas também a ausência de exigência de devolução do valor de benefícios recebidos indevidamente. Para uma servidora:

A CGU foi então aprendendo a fechar o cerco. [...] E ao questionarmos sobre essa situação da gente não poder tratar os achados de batimento dela, porque ali tinham famílias que não tinham atualizado cadastro após a obtenção da renda nova, ela passou a tirar isso também. Então ao final desse processo a CGU estava verificando a data de entrada no emprego formal, pela renda que ela achava de membro familiar, e a atualização cadastral, a última data de atualização cadastral e se essa atualização cadastral tinha acontecido depois da obtenção da renda. Então, ela começa agora no final a apresentar para a gente só esses achados. [...] Aí não tem jeito, se ela identifica uma renda nova, não lançada e essa renda foi obtida antes da última atualização cadastral, significa que a família omitiu essa renda. (Entrevista realizada em 14 dez. 2017).

Durante o fim de 2015 e início de 2016, ainda antes do impedimento da presidenta Dilma Rousseff, o Departamento do Cadastro Único encabeçou, na Senarc, a pauta da integração de bases de dados e sistemas de informação. Foi organizada uma oficina nacional com órgãos do governo federal, gestores de grandes bases de dados e sistemas de informação, como a Dataprev, a Receita Federal, o Ministério do Trabalho e Previdência Social, entre outros, e um seminário internacional para conhecer experiências de integração de bases de dados e sistemas de informação em outros países. ${ }^{6}$

5 De acordo com a Nota Técnica 113 Senarc/MDS de 12 de maio de 2016, a fiscalização do PBF consiste na apuração de recebimento indevido de benefícios em função de informação falsa prestada de forma intencional pelos beneficiários ou por agentes públicos, o que se diferencia da checagem em lote da consistência das informações dos registros das famílias por meio de cruzamentos de bases de dados.

6 As informações sobre o Seminário Internacional de Integração de Bases de Dados e Sistemas de Informação podem ser encontradas no seguinte link: http://wwp.org.br/eventos/ 
Entre os temas discutidos nesses dois eventos, os participantes destacaram o da cooperação entre diferentes órgãos governamentais para a integração de dados e uma visão de conhecimento da realidade dos cidadãos a partir de dados de diferentes fontes. Era uma pauta que parecia ter em mente tanto a provisão de serviços públicos considerada mais adequada para cada perfil de cidadão como a racionalização da utilização dos recursos públicos, visto que seriam aperfeiçoados os mecanismos de identificação de sobreposição de recursos destinados para um mesmo cidadão.

Ao discutir integração de bases de dados, os próprios gestores começam a reavaliar o conceito de autodeclaração. Eles passam a ter contato com experiências internacionais que já utilizaram a autodeclaração e a utilizar outros métodos de registro das informações das famílias. Além disso, buscam uma aproximação com outros órgãos com a finalidade de acessar bases de dados que poderiam ser integradas ao Cadastro Único. De acordo com uma ex-gestora:

Eu acho que era um procedimento meio natural para nós chegar nesse ponto, e chegar no ponto não só da averiguação. A gente só faz averiguação a posteriori porque a gente não tem condição de fazer na habilitação, a priori. (Entrevista realizada em 9 out. 2017).

Na verdade, a checagem de dados na habilitação já vinha sendo testada, mas em função de dificuldades técnicas ela não era possível. A autodeclaração, embora tenha sido uma justificativa importante tanto para os órgãos externos quanto para a construção da lógica de operação do Cadastro Único, parece ter sido sempre algo que poderia ser substituído caso fosse encontrada uma solução mais adequada. De acordo com uma ex-servidora:

Assinamos um contrato com a Dataprev, que não sei se está vigente, mas assinamos um contrato com a Dataprev e o primeiro batimento que eles se comprometeram a fazer, era um batimento com a base de famílias habilitadas, ou

seminario-internacional-de-integracao-de-base-de-dados-e-sistemas-de-informacao-paraaperfeicoamento-de-politicas-publicas/. Acesso em 27/06/2017. 
seja, nós estávamos falando de fazer batimento com a fila. [...] A gente já estava em uma situação muito boa pra iniciar. O problema é que a Dataprev, pelo que eu consegui acompanhar, a Dataprev não conseguiu fazer as entregas pra gente de maneira minimamente adequada. [...] Minha posição como gestora era simples, eu hoje estou massacrando uma equipe pra fazer batimentos de uma maneira extremamente desestruturada em que qualquer erro que ocorra pode resultar em responsabilização dessa equipe. (Entrevista realizada em 27 out. 2017).

Nesse contexto de questionamentos externos e respaldo interno, a experimentação criativa se deu a partir da busca por evidências de que as soluções encontradas eram adequadas, da normatização de procedimentos e da antecipação de possíveis questionamentos. Os problemas a serem resolvidos se tornaram cada vez mais repetitivos e desafiavam as decisões tomadas na urgência da resolução dos grandes problemas. Isso faz com que as soluções sejam também no sentido de institucionalizar procedimentos com a finalidade de responder, tanto interna quanto externamente, que uma ação rotineira é feita para evitar erros de focalização.

Ao mesmo tempo, percebe-se que enfatizar o erro de exclusão em detrimento do de inclusão não era suficiente no momento da interlocução com os órgãos de controle. Assim, busca-se antecipar soluções para problemas que podem surgir a partir da identificação das brechas nos argumentos dados aos órgãos externos. O contrato com a Dataprev para a realização de checagens no momento da habilitação no programa e a realização do seminário de integração de bases de dados foram claros esforços de antecipação de possíveis questionamentos. O primeiro tentou superar entraves técnicos da própria Senarc que impediam um esforço de checagem mais constante; o segundo tentou identificar soluções encontradas por outros países para os mesmos desafios de forma que o Cadastro Único não ficasse sempre dependente da autodeclaração e das checagens a posteriori sempre questionadas pelos órgãos de controle.

Nesse momento, contudo, essas experimentações tinham maior caráter de sondagem das possibilidades do que de implementação de soluções. Em uma visão de coevolução, é possível perceber que a equipe da Senarc 
ainda não tinha como contar com outros atores do sistema para solucionar os problemas que enfrentavam, respondendo aos órgãos de controle de forma a manter as preocupações com o erro de exclusão e justificar os erros de inclusão. Nessa perspectiva, é possível argumentar que as condições necessárias para a resolução desse problema só se apresentaram no contexto seguinte.

\subsection{Terceiro contexto: questionamento externo e interno}

No final de abril de 2016, o TCU publicou que uma auditoria realizada pelo órgão encontrou mais de 160 mil famílias com indícios de irregularidade. Essa notícia foi repercutida nos principais jornais do país. ${ }^{7}$ Em 17 de abril de 2016 a Câmara dos Deputados aprovou a abertura do processo de impedimento da presidenta Dilma Rousseff, afastando-a temporariamente do cargo. No final de maio de 2016, o Ministério Público Federal publicou que 1,4 milhões de beneficiários do PBF estavam com inconsistências, o que abarcava $\mathrm{R} \$ 2,5$ bilhões de recursos pagos. ${ }^{8}$

Em aproximadamente um mês, os servidores da Senarc se viram em uma situação de incerteza e de ameaça muito grande. Não sabiam se o governo seguinte daria a mesma importância às políticas sociais que o governo petista tinha dado ou se havia intenções de modificar o desenho do programa. Precisavam, ainda, de responder os questionamentos de que a gestão do PBF e o Cadastro Único permitiam o pagamento de benefícios a famílias com irregularidades.

Junto com o alto escalão, partiram do MDS os secretários nacionais de todas as secretarias, exceto o da Senarc, que era um gestor de carreira. Enquanto boa parte dos diretores no ministério pediu exoneração, na Senarc somente um diretor saiu. A tônica nesse momento, na Senarc, era resistir por dentro, tentar defender o programa para que ele não fosse descaracterizado.

7 http://www1.folha.uol.com.br/poder/2016/04/1765505-em-auditoria-no-bolsa-familiatcu-aponta-12-de-beneficiarios-indevidos.shtml. Acesso em 27/06/2017.

8 http://www1.folha.uol.com.br/poder/2016/05/1776564-ministerio-publico-veirregularidades-de-r-25-bilhoes-no-bolsa-familia.shtml; http://www.raioxbolsafamilia. mpf.mp.br/raioxbolsafamilia/diagnostico. Acesso em 27/06/2017. 
Havia a percepção de que poderiam ser capazes de argumentar contra a nova direção e convencê-la a manter o desenho do programa por meio de justificativas técnicas.

Envoltos no contexto de incerteza e de questionamento, a solução encontrada pelos gestores foi criar um Grupo de Trabalho Interinstitucional (GTI) que contou com a presença de técnicos da Senarc, do Ministério do Planejamento, da CGU, do TCU, da Caixa Econômica Federal, e do Instituto Nacional de Seguro Social (INSS). Essa foi uma demanda da própria direção do MDS que, a partir da divergência de dados do Ministério Público Federal, do TCU e CGU e da averiguação cadastral realizada pela própria Senarc, solicitou um número único de inconsistências cadastrais, calculado a partir de uma metodologia única de trabalho.

De acordo com uma entrevistada da Senarc participante desse grupo, o início das ações foi mais político, contou com a presença do secretário executivo, mas à medida que o grupo se desenvolveu as discussões tornaram-se mais técnicas, e os consensos foram sendo construídos. Algumas servidoras do Cadastro Único buscaram emplacar a pauta da integração de bases de dados já em andamento, mas houve a priorização da construção de procedimentos restritos ao PBF em detrimento de estratégias voltadas ao Cadastro Único.

Embora o foco tenha sido mais nas estratégias de aumento do controle dos procedimentos do $\mathrm{PBF}$, de acordo com uma servidora:

no período foi muito difícil, foram seis meses, com os órgãos, até você explicar o que a gente já fazia, quais possibilidades a gente tinha de melhoria, que não dava pra fazer tudo da noite pro dia, foi difícil. Mas passado isso, eu vejo isso como uma coisa muito positiva, os projetos que a gente tinha de melhoria do Cadastro Único ganharam força depois do GT. (Entrevista realizada no dia 23 jun. 2016).

Para ela, foi uma oportunidade, inclusive, de encaminhar pautas que não tinham tanta importância na Senarc, como a da integração das bases de dados. Com o GTI, a Senarc passou a ter acesso a bases de dados que não tinha anteriormente. O diálogo com outros órgãos foi positivo porque foi possível compartilhar com outros atores os desafios envolvidos no cruzamento de bases de dados e avançar na discussão sobre a integração dessas bases. 
De acordo com a servidora pública, a instabilidade política aliada ao questionamento das ações de controle do Cadastro Único e PBF foram importantes para que essa pauta, ainda incipiente na Senarc, ganhasse força. Para ela, sem o fortalecimento dessa pauta dentro da Senarc, seria provável que nem pautas encabeçadas pelos próprios servidores fossem encaminhadas porque não eram prioridades da gestão anterior. De acordo com a servidora:

[...] com essa possibilidade de integrar essas bases de dados no planejamento eu tenho a oportunidade de melhorar o próprio processo de cadastramento. Ao invés de ficar mandando a família voltar várias vezes no ano, [...] abre essa possibilidade que talvez eu tenha de trazer essas bases de dados, posso ir lá, fazer os cruzamentos e dar uma resposta para família na hora que ela está incluindo ou atualizando, que é o que a gente sempre quis. Essa perspectiva nossa não mudou do GTI pra cá, a gente sempre quis isso antes do GTI. A própria equipe já tinha amadurecido essa evolução do cadastro, a necessidade de fazer checagens com menos tempo, o GTI só externaliza aquilo que a gente já lia. (Entrevista realizada em 23 jun. 2017).

A centralidade que a averiguação cadastral tomou com a mudança de governo possibilitou que pautas antigas fossem implementadas, como a verificação a priori das informações de renda para impedir a habilitação das famílias com dados inconsistentes. Se antes essa ação não era feita porque 0 cruzamento de dados que deveria ser automatizado ficava nas mãos de servidores que poderiam cometer erros e ser responsabilizados pela concessão ou cancelamento de benefícios, após o GTI, foram automatizados muitos dos batimentos, que passaram a ser implementados pela Caixa Econômica Federal ou pela Dataprev, que tinham mais recursos tecnológicos para isso.

Além disso, para além do processo anual de averiguação cadastral que mobilizava as gestões municipais, passaram a ser feitas também verificações adicionais das famílias já beneficiárias e das habilitadas que ainda não participavam do programa, ou seja, da fila de espera do PBF. Essas últimas passariam a ser impedidas de receber o benefício, mesmo tendo o perfil para isso, caso fossem encontradas divergências de informações. A viabilização de cruzamentos de bases de dados ocorreu de tal forma que uma família 
incluída nos processos de verificação da folha de pagamento do PBF e da lista de habilitados somente poderia acessar o benefício caso atualizasse 0 cadastro e declarasse uma renda semelhante à que estava contida no registro administrativo que apontara inconsistência de informações de renda.

Essa nova ação questiona o conceito de autodeclaração do Cadastro Único. Afinal, se a família deve declarar renda semelhante à renda do outro registro administrativo, a renda do outro registro é que está sendo utilizada como referência. Também questiona o conceito de autodeclaração o projeto encaminhado à Caixa Econômica Federal de averiguação online, que prevê a apresentação da renda de outros registros para o entrevistador do Cadastro Único no momento da inclusão ou atualização cadastral. Ora, se o entrevistador tem a informação de que uma pessoa tem uma renda específica, seria muito arriscado registrar outra renda, mesmo que a família assim declare. Dessa forma, o próprio desenvolvimento das ações mobilizadas pela equipe da Senarc e respaldadas por uma gestão que deu força às ações de averiguação questiona o conceito que deu base para a criação desses procedimentos.

Não é só em função do aumento da capacidade de cruzamentos de bases de dados que a autodeclaração passa a ser reavaliada. Enquanto alguns gestores veem com resistência o questionamento desse conceito que foi fundante para a operacionalização do Cadastro Único, outros acham que ele tem atrapalhado mais do que ajudado considerando os procedimentos que passaram a ser adotados após o GTI.

A primeira vez que eu me peguei defendendo a não declaração, a não autodeclaração do cadastro foi nesse novo governo [...]. Com todo esse negócio de pente-fino [...] uma das premissas é [...] que eu acredito mais na base de dados do que na declaração da família. Para mim, isso era claro, a base está aqui, está falando que não tem essa renda, vou acreditar na base e não vou acreditar na pessoa. [...] Só que o discurso era: "Não! Vamos manter a autodeclaração!" Só que se a família não declarasse aquilo que estava na base de dado, eu cortava o benefício dela, não ia adiantar nada e eu ia impedir ela vir pro Bolsa. Aí foi a primeira vez que eu falei "gente, se o Estado tem essa informação, se o Estado está falando que essa informação para ele é a mais crível e que para mim o que a família falar, eu não 
vou considerar, o que me importa é o que está na base de dados, então vamos usar a informação". [...] Então o Estado tem que se responsabilizar por estar tomando essa decisão, de que eu confio mais na base de dados. Não jogar o ônus para a família, não falar que ela mentiu. Não falar que o município que não dá conta. Vamos assumir que eu acredito na base de dados e vamos usar essa informação para concessão de qualquer benefício. (Entrevista realizada em 20 nov. 2017).

Essa fala mostra alguns dos desafios que os gestores do Cadastro Único e do PBF passaram a enfrentar quando os cruzamentos de bases de dados tornaram-se viáveis. Se a autodeclaração responsabiliza a família que deve informar sua situação, o cruzamento de bases de dados responsabiliza o Estado, que é detentor de diferentes registros coletados com metodologias distintas e precisa conciliá-las no momento de utilizar os dados para concessão ou cancelamento de benefícios. Se a forma de corrigir uma inconsistência identificada por meio de uma checagem a posteriori seria a convocação da família para uma atualização cadastral, com a checagem a priori, a família não tem como corrigir a situação a não ser informando o mesmo dado encontrado no outro registro ou corrigindo a informação que foi utilizada como referência na outra base de dados. Se o dado atualizado é visto como fidedigno, as gestões municipais precisam dar conta de simplesmente manter os dados das famílias atualizados, agora se é fidedigno o dado sem divergência com relação a outras bases de dados, não há o que as gestões municipais possam fazer para garantir a qualidade do dado, visto que elas não têm acesso às informações utilizadas nos cruzamentos de bases de dados.

Assim, no terceiro contexto, a experimentação criativa caracteriza-se por ser um aproveitamento de oportunidades viabilizado por meio de uma situação de coevolução. Se em um momento anterior os entraves apresentados por outros atores do sistema eram suficientes para protelar ações mais contundentes no sentido de prevenir o erro de inclusão, priorizando o erro de exclusão, neste momento, o contexto político forçou que esses entraves fossem superados. Com o questionamento externo e interno, as prioridades se modificaram e o que era dificuldade em um período anterior pôde se tornar viável. Contudo, a realização de projetos antigos de forma tão abrupta expôs muitas das contradições 
acomodadas ao longo da execução da política pública. Conceitos que antes foram válidos para operacionalizar o programa e o Cadastro Único passaram a ser reavaliados pelos próprios gestores que os forjaram.

O terceiro contexto ainda está em curso e não é possível saber quais serão os encaminhamentos para os desafios elencados. Contudo, a análise já mostra uma dinâmica bastante complexa de idas e vindas de decisões tomadas a respeito de como o Cadastro Único e o Programa Bolsa Família devem ser operacionalizados, dinâmica que se intensificou no contexto de ruptura política. Contudo, essas idas e vindas não são muito coerentes: situações que antes eram almejadas, mas avançavam com dificuldades, adquirem novo ritmo e se aproximam muito mais dos desejos dos burocratas. Contudo, isso vem acompanhado de um viés punitivista que contraria as crenças dos gestores, que resistem a algumas das mudanças, mesmo que elas não contradigam a própria trajetória da construção dessas políticas e se dispunham a outras, com o intuito de preservar essas mesmas crenças.

\section{Conclusão}

Este trabalho buscou responder à seguinte questão: a experimentação criativa ocorre da mesma forma em todos os contextos? Para isso, foram apresentados três contextos ao longo de duas políticas imbricadas, o Cadastro Único e o Programa Bolsa Família, e discutido como a experimentação criativa se deu nesses três contextos, que tinham em comum a disputa sobre se era mais importante priorizar o erro de inclusão ou de exclusão.

O conceito de autodeclaração ilustra bem esse processo: forjado pragmaticamente para possibilitar uma meta ousada e urgente, ele passou a ser considerado fundante para o Cadastro Único. Alcançada a meta e viabilizados meios de checagem das informações declaradas a priori, esse conceito perde a relevância. Contudo, ainda não se sabe qual o encaminhamento a ser dado para essa questão, porque este conceito estrutura a forma como é feita a coleta de informações em todos os municípios brasileiros. Há um impasse e é a partir desse impasse que se espera que surjam novas soluções, ainda imprevisíveis.

No primeiro contexto, o que se pôde perceber foi o papel de uma atriz situada entre diferentes níveis, dialogando com a equipe técnica e lhe 
auferindo autonomia para agir e resolver os problemas apresentados com os políticos e com os municípios, que seriam os atores implementadores da política. As inovações realizadas podem ser explicadas por essa capacidade de interlocução com os diferentes atores. Além disso, a secretária à época teve a possibilidade de criar uma equipe com homogeneidade de valores capaz de responder às necessidades postas de forma a fugir das práticas já existentes, mas não foram consideradas viáveis quando confrontadas com as dimensões dos problemas postos.

No segundo contexto, o que se identifica é uma situação de antecipação de problemas, construção de rotinas e justificação. É um contexto que favorece ações menos inovadoras, visto que as decisões tomadas partem mais de respostas aos outros atores do sistema do que à resolução de um problema propriamente dito. Isso porque, embora diferentes atores questionassem as decisões tomadas, não era prioridade forçar os outros atores do sistema a cooperar na busca de soluções que pudessem resolver os problemas postos. A defesa do erro de exclusão ainda era mais importante, e o erro de inclusão, para a equipe, era um problema que apenas começava a questionar as crenças dos servidores. Ainda assim, foi nesse contexto que as soluções para esses questionamentos internos e externos passaram a ser pensadas.

No terceiro contexto, a partir dos questionamentos internos e externos houve uma capacidade de maior inovação pela equipe da Senarc, ainda que parte dessa inovação contrarie as crenças dos servidores. Os outros atores do sistema foram pressionados a cooperar no momento de viabilizar ações que antes eram apenas planejadas. Nesse caso, pôde-se identificar uma situação de coevolução, mas essa situação não foi natural, mas pressionada a ocorrer. Se no período anterior a Caixa ou a Dataprev apresentavam empecilhos para realizar cruzamentos de bases de dados, no momento seguinte esses empecilhos foram forçados a serem superados.

A simples existência de uma crise política não explicou as mudanças e continuidades ocorridas após a ruptura institucional. A capacidade dos atores de negociar e experimentar soluções já em discussão para os problemas postos foi fundamental para que a política tomasse o rumo que tomou. Esse trabalho mostrou que, diferentemente das visões institucionalistas mais tradicionais, os atores foram capazes de reavaliar suas decisões, aproveitar oportunidades mesmo quando foram constrangidos e encontrar soluções 
inovadoras para os problemas que precisavam enfrentar. A crise política se assemelhou mais a um catalizador de ações, visto que, a partir dos problemas com que se deparavam, os gestores tiveram que avançar em temas ainda incipientes e pouco discutidos.

É evidente que o contexto importa, e este trabalho se soma a outros na tentativa de identificar como isso ocorre. Mas, a contrapelo de visões institucionalistas mais comuns, o argumento não é que contexto importa porque constrange os atores, visto que em todos os contextos apresentados os atores estão sendo constantemente questionados. O contexto importa porque apresenta novos problemas, exige esforços de justificação, inverte prioridades e força a implementação de soluções antes inviáveis. É uma visão que enfoca o papel do contexto na explicação de motivações para agir de uma forma e não de outra, e não no constrangimento dos atores que deixam de fazer algo em função de uma série de entraves.

\section{Referências}

ANDRADE, Fabio; LIMA-SILVA, Fernanda. High-level federal bureaucracy and policy formulation: the case of the Bolsa Família program. Brazilian Political Science Review, São Paulo, v. 10, n. 3, p. 1-26, 2016. ANSELL, Chris. Ecological explanation. In: BERK, Gerald; GALVAN, Dennis C.; HATTAM, Victoria (org.). Political creativity: reconfiguring order and change. Philadelphia: University of Philadelphia Press, 2013.

BATISTA, Matias. Os municípios nos governos FHC e Lula: uma abordagem sob o ponto de vista da ação legislativa. 2008. 58 f., il. Monografia (Especialização em Ciência Política) - Universidade do Legislativo Brasileiro, Brasília, 2008.

BERK, Gerald; GALVAN, Dennis. How people experience and change institutions: a field guide to creative syncretism. Theory and Society, v. 38, n. 6, p. 543-580, 2009. 
BICHIR, Renata. Mecanismos federais de coordenação de políticas sociais e capacidades institucionais locais: o caso do Programa Bolsa Família. 2011. 271 f., il. Tese (Doutorado em Sociologia e Ciência Política) - Instituto de Estudos Sociais e Políticos, Universidade do Estado do Rio de Janeiro, Rio de Janeiro, 2011.

BLUMER, Herbert. Symbolic interactionism: perspective and method. Englewood Cliffs, NJ: Prentice-Hall, 1969.

BOLTANSKI, Luc; THÉVENOT, Laurent. The sociology of critical capacity. European Journal of Social Theory, v. 2, n. 3, p. 359-377, 1999.

BRASIL. Ministério do Desenvolvimento Social. Nota Técnica $n^{0} 113$, de 12 de maio de 2016. Brasília: Senarc/MDS, 2016.

EIRÓ, Flávio. Pauvreté, stigmatisation et citoyenneté: le rôle des assistantes sociales dans le clientélisme brésilien. Comunicação. In: CONGRÈS DE L'ASSOCIATION FRANÇAISE DE SOCIOLOGIE, 7., 3 a 6 jul., Université de Picardie Jules Verne, Amiens, 2015.

FLIGSTEIN, Neil. Social skill and the theory of fields. Sociological Theory, v. 19, n. 2, p. 105-125, 2001.

JOAS, Hans. The creativity of action. Chicago: University of Chicago Press, 1996.

KINGDON, John W. The policy primeval soup. In: KINGDON, John W. Agendas, alternatives, and public policies. Edinburgh: Pearson Education, 2015.

LICIO, Elaine. Para além da recentralização: os caminhos da coordenação federativa do programa Bolsa Família. 2012. xv, 351 f., il. Tese (Doutorado em Política Social) - Instituto de Ciências Humanas, Universidade de Brasília, Brasília, 2012.

OLIVEIRA, Vanessa; LOTTA, Gabriela S. Implementando uma inovação: a burocracia de médio escalão do Programa Bolsa Família. In: LOTTA, Gabriela S.; CAVALCANTE, Pedro (org.). Burocracia de médio escalão: perfil, trajetória e atuação. Brasília: Enap, 2015. 
SEWELL JR, William H. A theory of structure: duality, agency, and transformation. American Journal of Sociology, v. 98, n. 1, p. 1-29, 1992.

SHEINGATE, Adam D. Political entrepreneurship, institutional change, and American political development. Studies in American Political Development, v. 17, n. 2, p. 185-203, 2003.

VIEIRA, Ana. A multiestratégia de implementação do Programa Bolsa Família e do Cadastro Único no período 2005 a 2007. 199 f., il. Dissertação (Mestrado Profissional em Saúde Pública) - Fundação Oswaldo Cruz Escola Nacional de Saúde Pública Sergio Arouca, Rio de Janeiro, 2011.

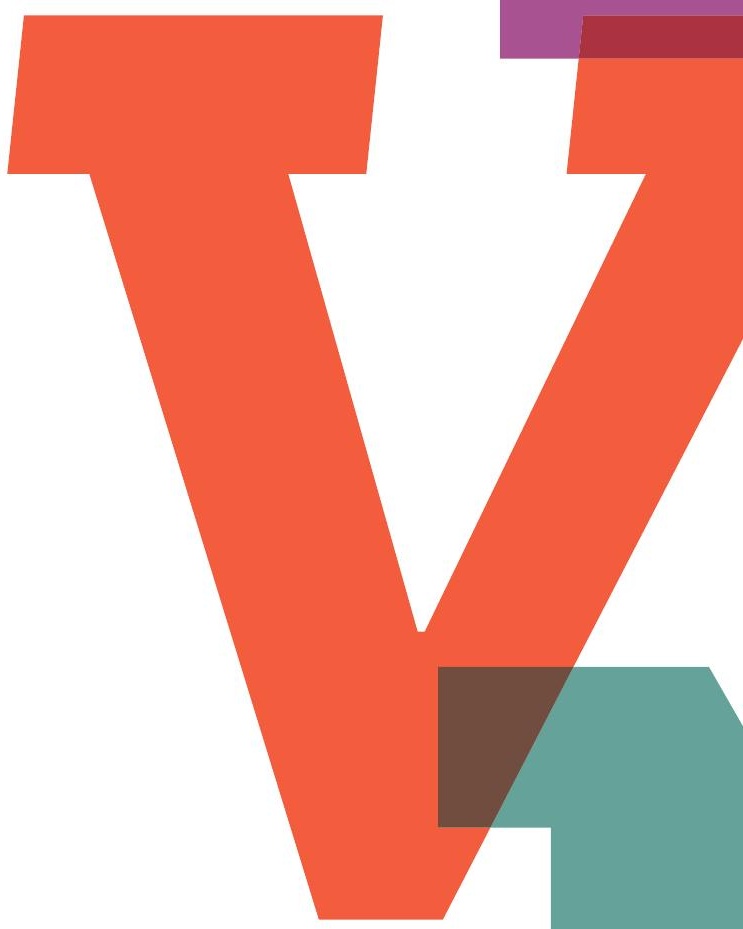




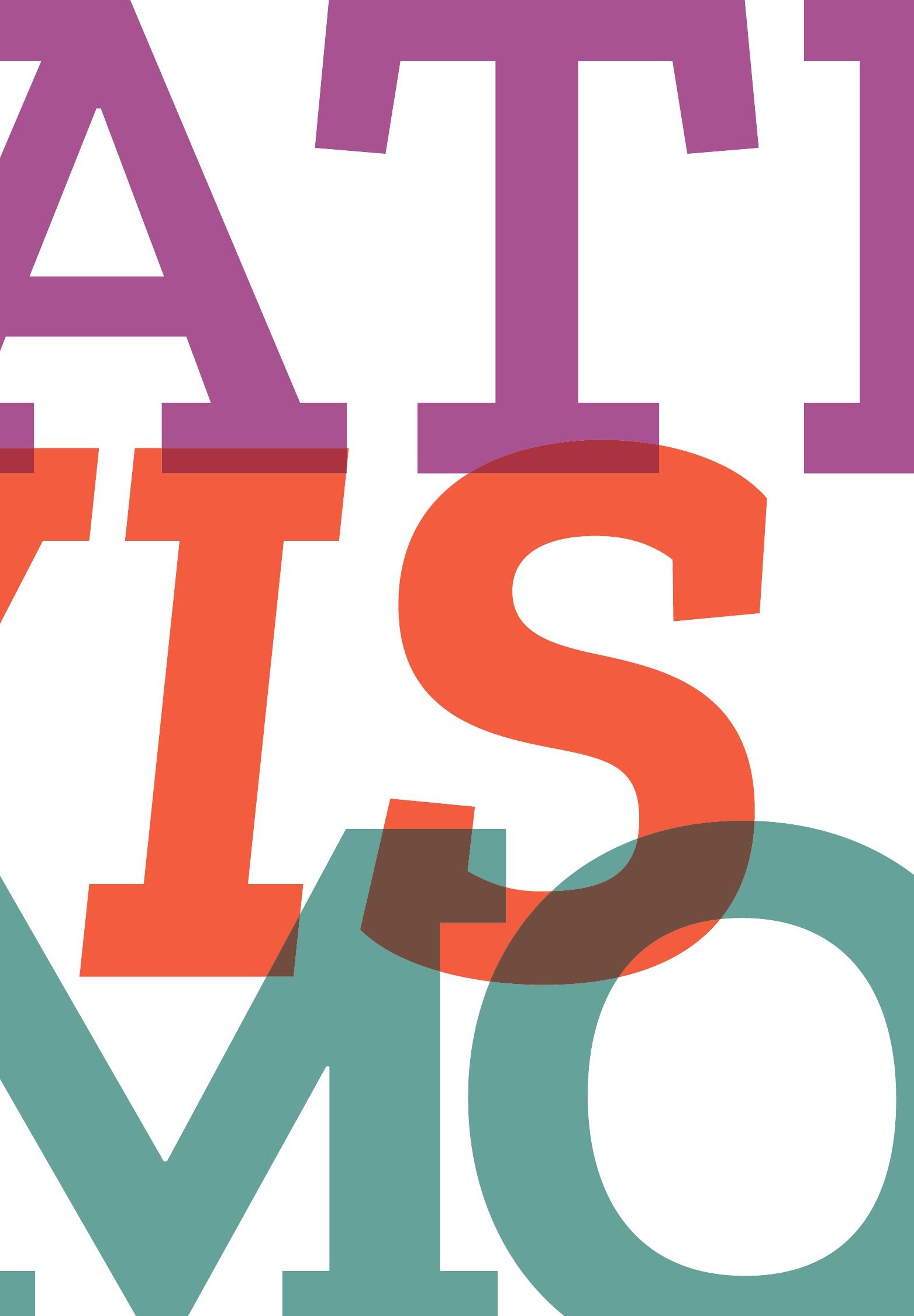




Este livro foi composto em Zilla Slab e Liberation Serif, no formato 16x23 cm, e impresso no sistema offset, sobre papel offset $75 \mathrm{~g} / \mathrm{m}^{2}$, com capa em papel-cartão supremo $250 \mathrm{~g} / \mathrm{m}^{2}$. 


\section{"Este livro rompe com o tédio tipicamente associado ao senso comum sobre a}

burocracia. O funcionamento do Estado adquire aqui

carne, sangue e sentimento, em lutas pela defesa de

causas e soluçoes aos problemas públicos. O conceito

de ativismo institucional revitaliza a agenda de estudos

sobre instituiçòes e politicas públicas, trazendo para o

centro a açào criativa no interior da burocracia."

\section{Roberto Pires (Ipea)}

"Ao iluminar de modo arguto o papel

transformador e criativo de um tipo de açảo coletiva que ocorre no seio do ator estatal por excelência, a burocracia, este livro é imprescindivel para todos os interessados em entender a transformação das políticas públicas no Brasil pós-transiçào e em pensar as disputas hoje em curso."

Adrian Gurza Lavalle (USP)

"Um marco para os que estudam os atores dentro do Estado e para quem está preocupado em abrir a caixa preta estatal para entender como as coisas de fato acontecem. O livro nos brinda com análises $e$ evidências profundas do 'Estado em Açào' a partir da açào dentro do Estado. Imperdivel para o estudo da burocracia, dos movimentos sociais, das interfaces do Estado e da produçào de políticas públicas."

\section{Gabriela Lotta (FGV)}

"Este livio mostra como a burocracia pode se transformar em arena de luta e como os servidores públicos podem se tornar agentes de mudança. Os autores nos convidam a pensar a contestaço política por dentro do Estado. Uma leitura imprescindivel para a compreensto do ativismo contemporâneo:" 